\title{
PRISCILA RODRIGUES GOMES
}

Indicadores ambientais na discussão da sustentabilidade: uma proposta de análise estratégica no contexto do etanol de cana-deaçúcar no Estado de São Paulo

Dissertação apresentada à Escola de Engenharia de São Carlos da Universidade de São Paulo para obtenção do título de mestre em Ciências da Engenharia Ambiental.

Área de Concentração: Ciências da Engenharia Ambiental.

Orientador: Prof. Dr. Tadeu Fabrício Malheiros 
AUTORIZO A REPRODUÇÃO E DIVULGAÇÃO TOTAL OU PARCIAL DESTE TRABALHO, POR QUALQUER MEIO CONVENCIONAL OU ELETRÔNICO, PARA FINS DE ESTUDO E PESQUISA, DESDE QUE CITADA A FONTE.

Ficha catalográfica preparada pela Seção de Tratamento da Informação do Serviço de Biblioteca - EESC/USP

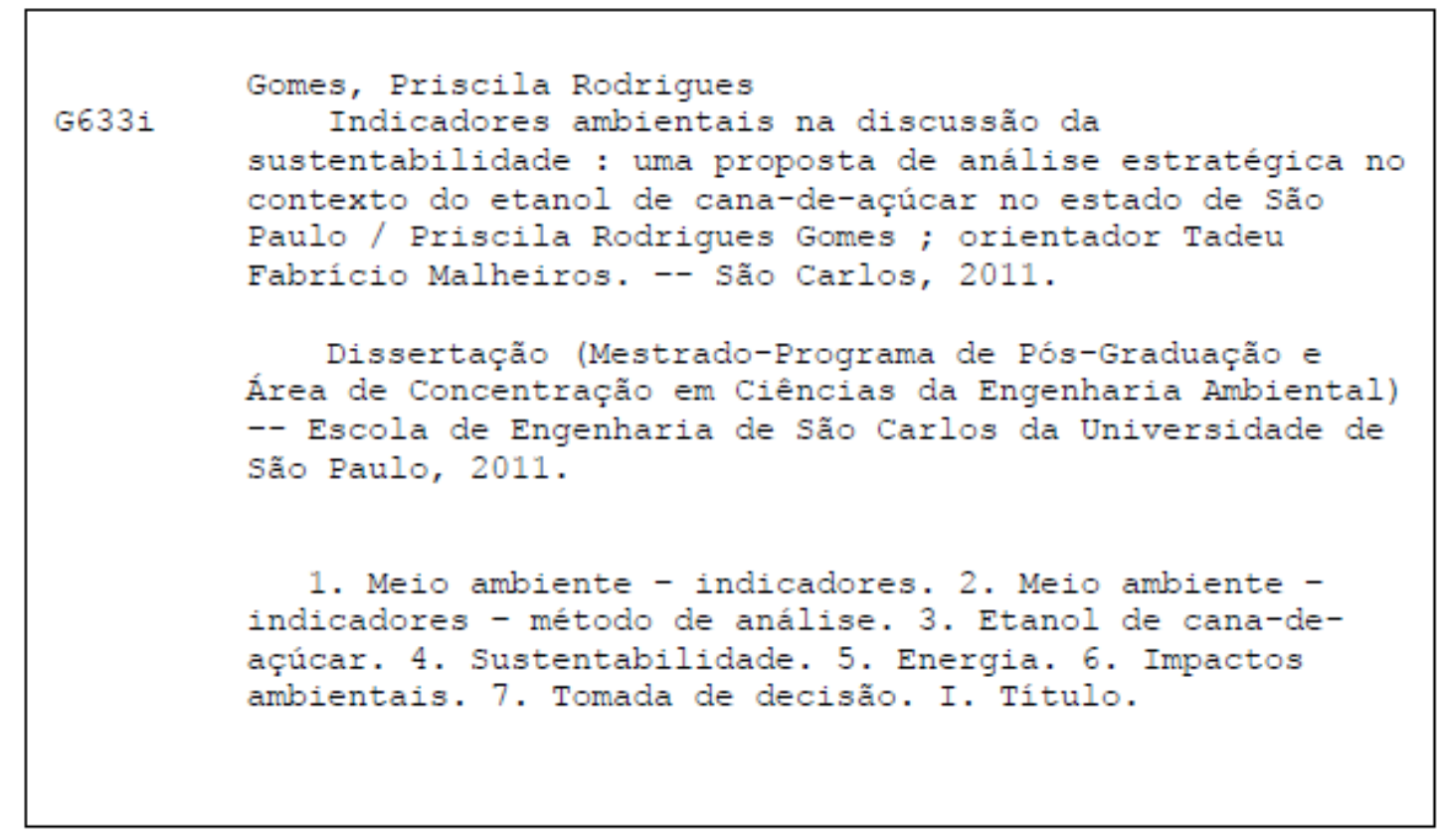




\section{FOLHA DE JULGAMENTO}

Candidato(a): Bacharel PRISCILA RODRIGUES GOMES.

Dissertação defendida e julgada em 21.02.2011 perante a Comissão Julgadora:

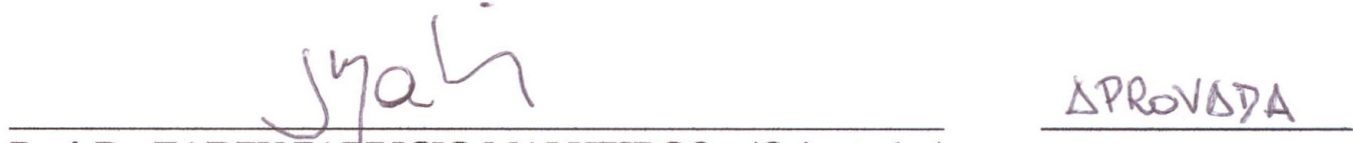

Prof. Dr. TADEU FABRICIO MALHEIROS - (Orientador)

(Escola de Engenharia de São Carlos/USP)
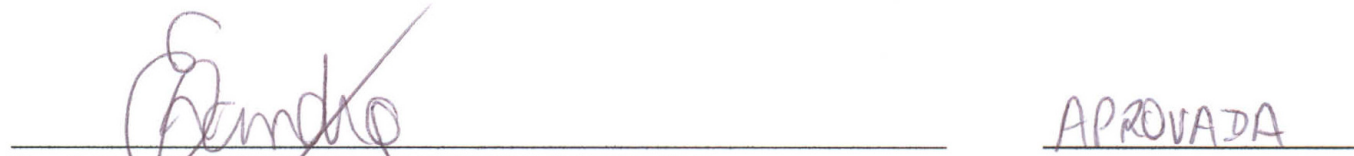

Prof. Dr. EVANDRO MATEUS MORETTO

(Escola de Engenharia de São Carlos/USP)

\section{PARTICIPACAOO POR VIDEOCONFERENCIA}

Prof. Dr. VALDIR FERNANDES

(FAE Centro Universitário)

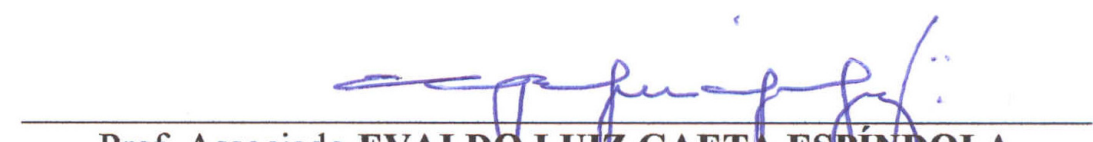

Prof. Associado EVALDO LUI GAETA ESÁínDOLA

Coordenador do Programa de Pós-Graduaçáo em

Ciências da Engenharia Ambiental

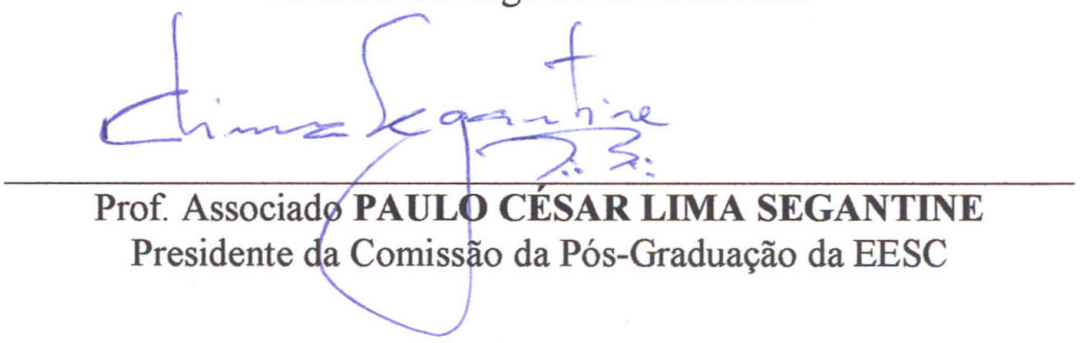




\section{DEDICATÓRIA}

Ao meu companheiro, Rodrigo Alves Silva, com amor, admiração e gratidão por sua compreensão, carinho, presença e incansável apoio ao longo do período de elaboração deste trabalho. 


\section{AGRADECIMENTOS}

A minha mãe Roseli Sevilha Rodrigues, ao meu pai Eduardo Gomes e a minha irmã Amanda Rodrigues Gomes, pelo apoio, incentivo, preocupação e compreensão.

Ao orientador Prof. Dr. Tadeu Fabrício Malheiros, pela condução e pela condição de amadurecimento dado a mim no desenvolvimento desta pesquisa.

Aos professores Dr. Valdir Fernandes e Dr. Evandro Mateus Moretto, integrantes da banca examinadora e colaboradores da melhoria do trabalho.

Aos especialistas consultados, pelo apoio, ensinamentos e aprofundamentos dados no desenvolvimento e fechamento da pesquisa.

Aos professores Dr. Frederico Yuri Hanai, Dr. Evandro Mateus Moretto e Dr.Valdir Fernandes pelo apoio e incentivo dado a mim e pela orientação em dúvidas existentes.

Aos alunos do Centro de Recursos Hídricos e Ecologia Aplicada do Departamento de Hidráulica e Saneamento da Escola de Engenharia de São Carlos da Universidade de São Paulo, pelas inúmeras conversas e dúvidas debatidas no desenvolvimento e finalização do estudo.

A todos os professores do Departamento de Hidráulica e Saneamento de São Carlos da Universidade de São Paulo, aqui representados pelo Coordenador do Programa de Pós Graduação, Prof. Dr. Evaldo Luiz Gaeta Espíndola pela dedicação, ensinamentos e pela orientação em dúvidas existentes.

Aos funcionários do Departamento de Hidráulica e Saneamento da Escola de Engenharia de São Carlos da Universidade de São Paulo, aqui representados pelos secretários de PósGraduação Nelson Emanuel Tessarin e José Luiz Donizete Chiaretto, pelo suporte administrativo e pessoal disponibilizado e sem o qual não seria possível o desenvolvimento do estudo.

A FAPESP (Fundação de Amparo à Pesquisa de São Paulo), pela concessão de bolsa de mestrado e ao Projeto AISe - BIOEN (processo número 2008/58033-3) pelo auxílio financeiro e no desenvolvimento desta pesquisa.

Ao Programa de Pós-Graduação em Ciências da Engenharia Ambiental pela oportunidade disponibilizada para aprimorar os conhecimentos e obtenção do título.

A todos os meus amigos que sempre estiveram em pensamento me apoiando e me dando forças para desenvolver este trabalho. 
"Se pudéssemos primeiro saber onde estamos e para onde estamos tendendo, poderíamos avaliar melhor o que fazer e como fazê-lo." (Abraham Lincoln, o discurso do Illinois convenção estadual republicana, 16 de junho, 1858). 


\section{RESUMO}

GOMES, P. R. Indicadores ambientais na discussão da sustentabilidade: uma proposta de análise estratégica no contexto do etanol de cana-de-açúcar no estado de São Paulo. 167 p. Dissertação (Mestrado) - Escola de Engenharia de São Carlos, Universidade de São Paulo, São Carlos, 2011.

Atualmente verifica-se uma significativa demanda da sociedade e gestores por informações e ferramentas que permitam colocar em prática o conceito de desenvolvimento sustentável e efetivamente internalizar nas políticas, planos, programas e projetos o reconhecimento da interdependência entre as diversas dimensões, tais como: ambientais, econômicas, sociais e institucionais. De forma crescente a temática da sustentabilidade tem trazido novas variáveis às arenas de discussão e tomada de decisão ao considerar as diversas variáveis dentro de um mesmo plano. Uma das principais motivações para a consideração da interdependência destas dimensões é a fragilidade do modelo de desenvolvimento baseado na utilização de fontes não renováveis de energia, bem como seus impactos no meio sócio-ambiental e reflexos no meio econômico. Neste cenário, o etanol de cana-de-açúcar enquanto fonte renovável de energia surge como potencial substituto ao uso de combustíveis à base de petróleo (notadamente a gasolina), em especial no Brasil, onde o mesmo é uma realidade. Observa-se um otimismo e incentivo quanto às políticas públicas na área energética no que tange esta fonte, em especial com políticas de incentivo ao seu crescimento. No entanto, observam-se também questionamentos da sociedade quanto à real sustentabilidade desta fonte energética, dados os impactos provenientes de sua cultura, produção e uso em larga escala. Estes questionamentos ganham força quando realizados no estado de São Paulo, dada a representatividade da atividade frente ao Brasil e ao mundo. Neste contexto, é evidenciada a importância da construção de ferramentas que possibilitem avaliar de forma integrada a sustentabilidade do etanol de cana-de-açúcar, bem como informar os tomadores de decisão, embasando políticas públicas voltadas para o desenvolvimento sustentável. Estas ferramentas, bem como as políticas embasadas por elas, passam, no estado de São Paulo, obrigatoriamente pela Secretaria do Meio Ambiente - SMA/SP. Os indicadores ao capturarem a complexidade do desenvolvimento, sem reduzir a significância de cada um dos componentes do sistema, figuram-se como tais ferramentas. Com o propósito de avaliar os indicadores ambientais produzidos pela SMA/SP à luz dos princípios e critérios de boas práticas na construção e uso de indicadores, o presente estudo busca contribuir para o avanço nas discussões, em especial em termos de métodos de avaliação de indicadores ambientais voltados para a sustentabilidade, tendo como contexto de estudo o etanol de cana-de-açúcar no estado. Este estudo apresentou um método conduzido por meio de entrevistas e uma oficina de especialistas que apontou, como resultado, um conjunto de critérios de referência para análise destes indicadores. Ainda como produto da pesquisa o método construído foi aplicado a um dos principais indicadores utilizados pela SMA, qual seja o IQA - Índice de Qualidade de Água, revelando, por meio de uma análise SWOT, as forças e fraquezas, oportunidades e ameaças deste indicador na discussão da sustentabilidade do etanol. Futuros estudos voltados para o aperfeiçoamento das aplicações são desejáveis para melhoria dos resultados e composição de um sistema adequado de formulação e avaliação dos indicadores para esta atividade.

Palavras-chave: Método de Análise; Etanol de cana-de-açúcar; Sustentabilidade; Indicadores Ambientais; Energia; Impactos Ambientais; Tomada de Decisão. 


\begin{abstract}
GOMES, PR Environmental indicators in the discussion of sustainability: a proposal for strategic analysis in the context of ethanol from sugar cane in São Paulo. 167 p. Dissertation (Master) - Engineering School of São Carlos, University of São Paulo, São Carlos, 2011.

Currently there is a significant demand of society and managers with information and tools to put into practicing the concept of sustainable development and effectively internalize the policies, plans, programs and interdependence recognition between the various dimensions such as environmental, economic, social and institutional. Increasingly the sustainability issue has brought new variables to discussion and decision making to consider the many variables within the same plane. One of the main motivations for considering the interdependence of these dimensions is the fragility of the development model based on the use of non-renewable energy sources, as well as its impacts on socio-environmental and consequences in the economic area. In this scenario, ethanol from sugar cane as a renewable source of energy emerges as a potential substitute to the use of petroleum-based fuels (in particular gasoline), especially in Brazil, where it is a reality. There is an optimism and encouragement concerning public policies in energy with respect to this source, particularly with policies to encourage its growth. However, there is also society questioning about the real sustainability of this energy source, given the impacts from its cultivation, production and use on a large scale. These questions gain strength when held in São Paulo State, given the representation of activity against Brazil and the world. In this context, it is evident the importance of building tools that will assess the sustainability into an integrated way about ethanol from sugar cane, and inform decision makers, basing public policies for sustainable development. These tools, as well as policies based on them, are in the state of Sao Paulo, necessarily by the Environment Secretary of São Paulo - SMA / SP. The indicators to capture the complexity of development without reducing the significance of each system component appear as such those tools. With the purpose of evaluating the environmental indicators produced by SMA / SP against the principles and good practice criteria in the construction and use of indicators, this study seeks to advance the discussions, particularly in terms of evaluation methods on indicators toward environmental sustainability, within the study context ethanol sugar cane in the state. This study presented a method conducted through interviews and a workshop of experts that pointed out as a result, a set of benchmarks for analysis of these indicators. Even as a research product the built method was applied to one of the main indicators used by the SMA, which is the WQI - Water Quality Index, revealing, through a SWOT analysis, strengths and weaknesses, opportunities and threats in this indicator to discuss the sustainability of ethanol. Future studies aimed at improving the applications are desirable for improved performance and composition of a proper system to design and evaluate indicators for this activity.
\end{abstract}

Key words: Analysis method; Ethanol from sugar cane; Sustainability, Environmental Indicators, Energy, Environmental Impacts, Decision-Making. 


\section{LISTA DE FIGURAS}

Figura 2.1- Fluxograma das Principais Etapas da Pesquisa 20

Figura 2.2 - A Estruturação do SISNAMA e a Posição da Secretaria Estadual do Meio

Ambiente e suas atribuições

Figura 2.3- Estrutura Organizacional da Secretaria do Meio Ambiente - SMA/SP...

Figura 2.4- Fases e etapas do ciclo de vida do etanol de cana-de-açúcar consideradas pela pesquisa

Figura 4.1- Pirâmide de informação e sua relação com o usuário.............................................5 57

Figura 4.2- Dimensão ambiental como componente da sustentabilidade ................................ 63

Figura 5.1- Uso de defensivos agrícolas pela cultura de cana-de-açúcar ................................ 97

Figura 6.1- Resultado do mapeamento dos indicadores ambientais ...................................... 115

Figura 6.2- Representação simplificada dos impactos negativos significativos do ciclo de vida do etanol de cana-de-açúcar

Figura 6.3 Conjunto de indicadores-chave correspondentes aos impactos negativos significativos do ciclo de vida do etanol de cana-de-açúcar

Figura 6.4- Impactos negativos significativos não cobertos pelos indicadores ambientais da Secretaria Estadual do Meio Ambiente

Figura 7.1- Estrutura de análise estratégica proposta ....................................................... 148 


\section{LISTA DE GRÁFICOS}

Gráfico 5.1- Evolução histórica da área plantada de cana-de-açúcar no Brasil ........................77

Gráfico 5.2- Produção de cana-de-açúcar por estado - safra 2008/09 ...................................... 79

Gráfico 5.3- Ocupação da cana no Estado de São Paulo ......................................................... 81

Gráfico 5.4- Evolução da área cultivada e da taxa de crescimento produtivo da cana-de-

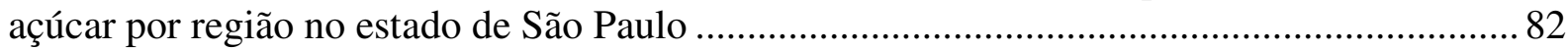

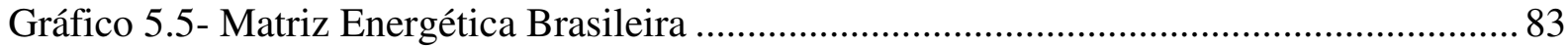

Gráfico 5.6- Matriz Energética Nacional por fonte de Energia............................................. 83

Gráfico 5.7- Evolução da representação da Matriz Energética por fonte no Brasil ................. 84

Gráfico 5.8- Gasto de energia pelo setor de transporte e decomposição do uso para o

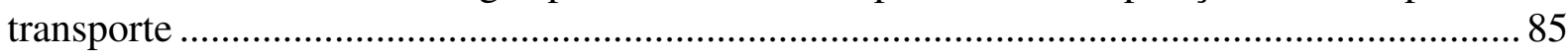




\section{LISTA DE QUADROS}

Quadro 2.1 Detalhamento da Pesquisa Bibliográfica (Base Conceitual) ...............................21

Quadro 2.2- Relatórios utilizados para o mapeamento dos indicadores ambientais ................ 30

Quadro 3.1- Principais marcos sobre o conceito de desenvolvimento sustentável .................. 43

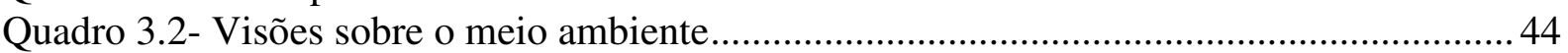

Quadro 3.3. As diferentes dimensões da sustentabilidade................................................ 48

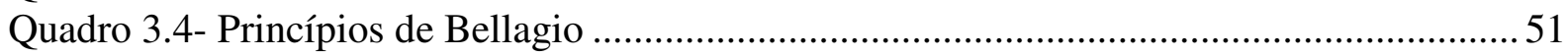

Quadro 4.1- Caracterização de um parâmetro como indicador ............................................. 55

Quadro 4.2- Diferença entre indicadores tradicionais e de sustentabilidade...........................66

Quadro 4.3- Condições para um indicador ideal .................................................................... 69

Quadro 5.1- Exemplos de Instituições mundiais e suas contribuições para a

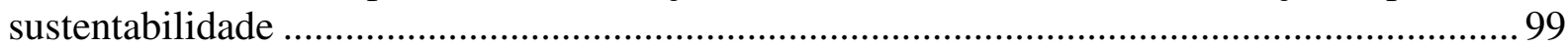

Quadro 5.2 - Interesse dos diversos stakeholders na certificação bioenergética ..................... 103

Quadro 5.3- Instituições e suas ações realizadas para o setor sucroalcooleiro........................ 105

Quadro 6.1- Produtos obtidos por meio dos procedimentos metodológicos adotados............ 108

Quadro 6.2-Impactos negativos significativos levantados da literatura e discutidos pelos especialistas da área ambiental (água,solo e ar) ................................................................ 118 Quadro 6.3- Impactos negativos significativos utilizados como base de seleção dos

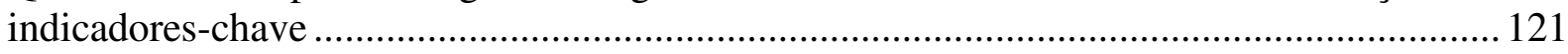

Quadro 6.4- Resultados da oficina - critérios de análise .................................................... 127

Quadro 6.5- Impactos negativos significativos cobertos pelo IQA ....................................... 130 


\section{LISTA DE TABELAS}

Tabela 5.1 - Emissões médias dos veículos homologados pelo Proconve ............................. 89

Tabela 5.2- Perdas de solo em culturas anuais e semi-perenes ............................................. 91

Tabela 5.3 - Intensidade do uso de fertilizantes por culturas no Brasil ....................................99

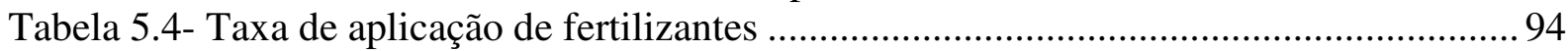

Tabela 5.5- Composição físico-química da vinhaça................................................................ 95

Tabela 5.6- Composição química aproximada de 100 gramas de torta de filtro ...................... 96

Tabela 5.7- Usos da água (valores médios) em usinas de álcool (destilarias)..........................98

Tabela 6.1- Resultados da análise dos pontos fortes e fracos do IQA................................... 128

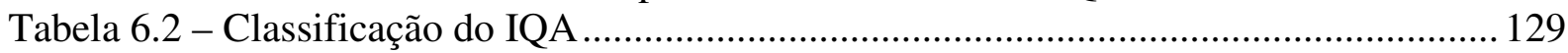

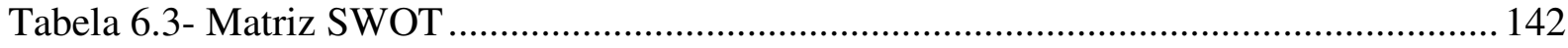

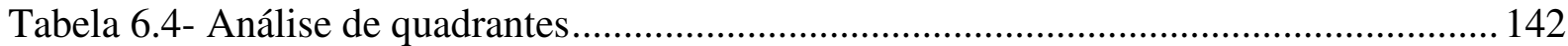




\section{SUMÁRIO}

1 INTRODUÇÃO

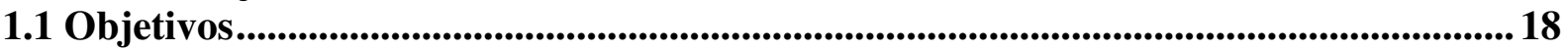

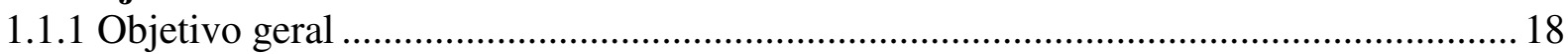

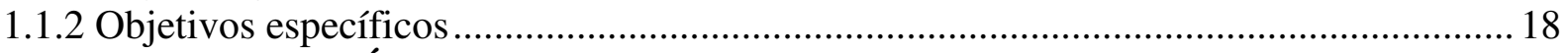

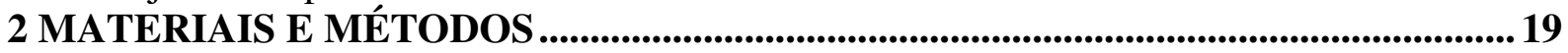

2.1 Descrição das etapas metodológicas................................................................................. 19

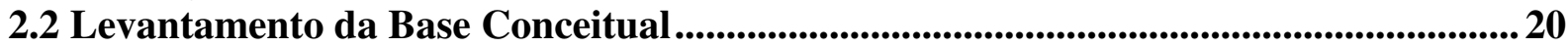

2.3 Caracterização do estudo de caso ................................................................................22

2.4 Mapeamento dos indicadores ambientais ...................................................................29

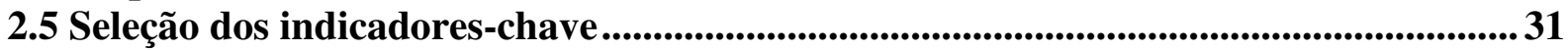

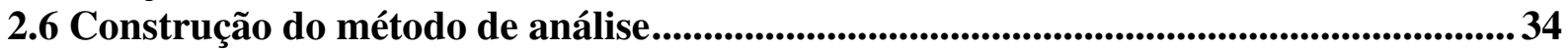

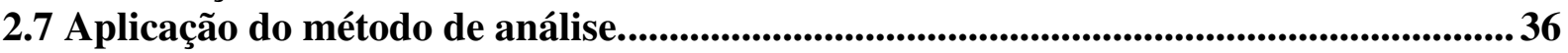

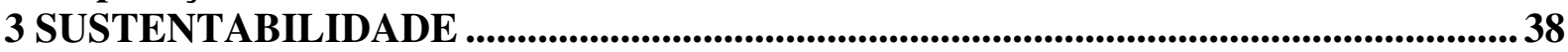

3.1 Origem do termo e sua evolução ................................................................................................39

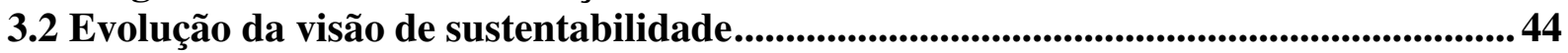

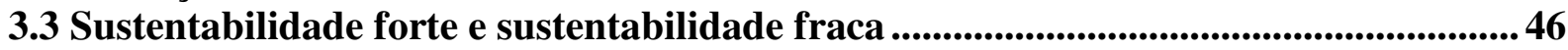

3.4 Aspectos relacionados à busca pelo desenvolvimento sustentável ...............................49

4 INDICADORES AMBIENTAIS NA INFORMAÇÃO E TOMADA DE DECISÃO.54

$4.1 \mathrm{O}$ que define um indicador? .....................................................................................54

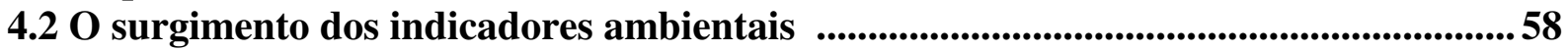

4.3 Indicadores ambientais - componente da Sustentabilidade.............................................61

4.4 Boas práticas na construção de indicadores .............................................................65

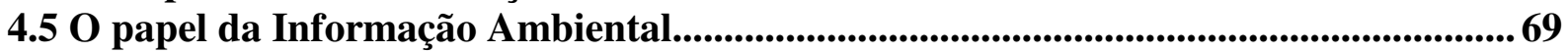

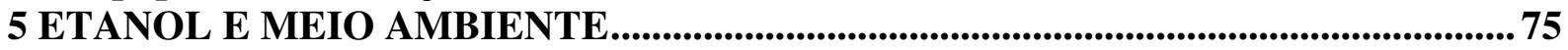

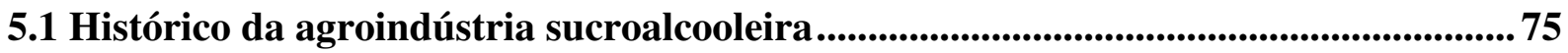

5.2 Atividade sucroalcooleira no estado de São Paulo ...................................................80

5.3 Etanol e a matriz energética nacional.............................................................................................. 82

5.4 Impactos ambientais negativos da atividade sucroalcooleira......................................... 86

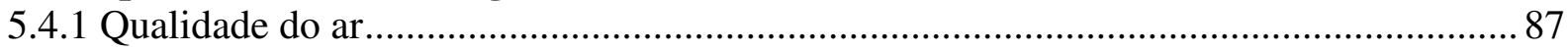

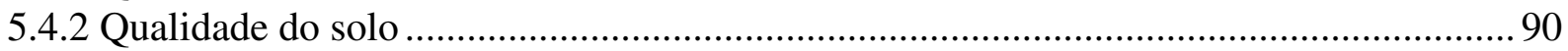

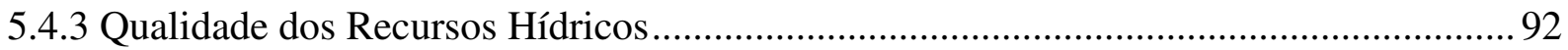

5.5 Discussões sobre sustentabilidade para o etanol de cana de açúcar ...........................99

5.6 Sustentabilidade para o etanol no contexto internacional .......................................... 101

5.7 Sustentabilidade para o etanol no contexto brasileiro ................................................... 104

6 ANÁLISE E DISCUSSÃO DOS RESULTADOS ....................................................... 107

6.1 Considerações sobre a base conceitual ....................................................................109

6.2 Fontes e método de obtenção dos indicadores (mapeamento) .....................................110

6.3 Sobre a escolha dos indicadores-chave (método de seleção dos indicadores) ............ 113

6.4 Método de Análise ................................................................................................................ 124

6.5 Aplicação do método de análise ao Índice de Qualidade da Água - IQA ................. 128

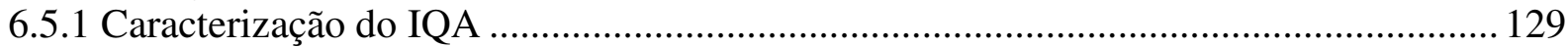

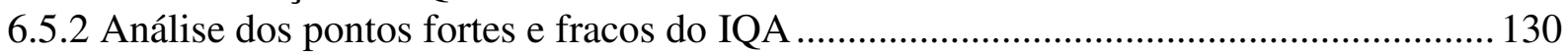

6.6 Considerações sobre a análise .......................................................................................... 137

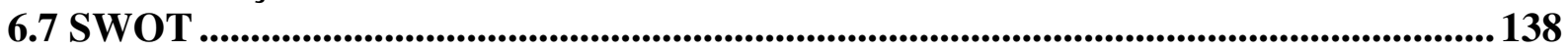

6.7.1 Cenário, Políticas Públicas e tomada de decisão ........................................................ 138

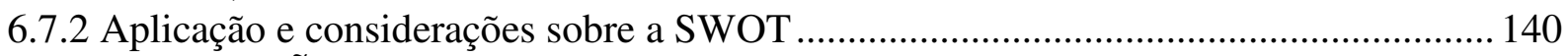

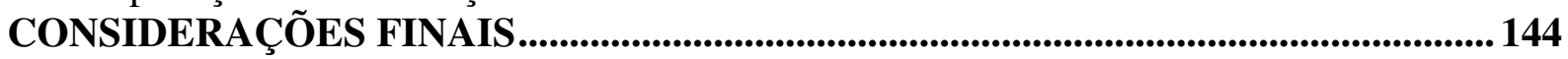




\section{INTRODUÇÃO}

Nos últimos anos, observaram-se avanços consideráveis sobre o desenvolvimento sustentável no mundo, tanto em seu conceito quanto na conscientização social. Estes incrementos se devem à intrínseca relação das variáveis condicionantes à qualidade de vida humana, que motivaram o reconhecimento da interdependência entre as dimensões ambientais, econômicas, sociais e institucionais (GOMES, 2004).

Do ponto de vista político-ideológico, a sustentabilidade é uma estratégia para construção de uma sociedade mais feliz, mas na prática, há um longo caminho a ser percorrido, transformando e ajustando as práticas de planejamento e gestão, do global ao local. (SANTOS, 2004).

O estilo sustentável como forma de desenvolvimento implica em mudanças nos processos de produção e consumo, principalmente no comportamento pessoal e social, como fator indutor do ponto de equilíbrio sócio-econômico e ambiental.

Para o enfrentamento destas questões, é preciso um processo coordenado e contínuo que articule os diferentes setores governamentais e não governamentais, que integre esforços, compatibilize a capacidade de suporte dos ecossistemas, a demanda de recursos ambientais e financeiros, e que assim permita construir as bases do desenvolvimento socialmente justo, ambientalmente correto e economicamente viável.

A implementação de um sistema de gestão ambiental, que possa negociar, compatibilizar e somar interesses de diferentes atores e integrar e avaliar políticas, nos âmbitos locais, regionais e nacionais representa alternativa indispensável para a construção de um desenvolvimento em bases sustentáveis.

Como expresso por Souza (2000), as estratégias de orientação do desenvolvimento em bases sustentáveis devem ser implementadas com a aplicação de instrumentos sociais, ambientais e econômicos compatíveis, e que as questões ambientais sejam consideradas ao longo de todo o processo de planejamento, desde seu início até suas avaliações.

Portanto, as questões presentes em maior ou menor intensidade nas pautas de discussão sobre sustentabilidade, referem-se à construção de modelos de desenvolvimento que favoreçam a inclusão de parte significativa da população como beneficiária dos avanços dos tratados internacionais de direitos humanos e das políticas de desenvolvimento social.

Tais modelos devem primar por um processo de melhoria contínua, com crescente bem estar populacional, o que demanda estratégias embasadas no enfoque da sustentabilidade, ou seja, estabelecimento de visão de futuro e metas, construídas de forma participativa e 
interativa, com sistema de monitoramento, análise e avaliação, com inclusão de mecanismos de aprendizagem por conta do sistema.

Portanto, neste contexto é de fundamental importância a constituição de um suporte robusto de dados ambientais, sociais e econômicos para o processo de tomada de decisão, fazendo com que este seja capaz de equacionar todas as demandas do processo de gestão baseada nos princípios da sustentabilidade.

De tal modo entra em cena a exigência de um sistema de indicadores em saúde e ambiente, cuja proposta é monitorar as interações entre ambiente, economia e sociedade como base de dados para planejamento estratégico e análise de políticas, de modo a identificar alternativas viáveis de construção do desenvolvimento mais duradouro e justo.

De acordo com Malheiros, Phillip Jr. e Aguiar (2005) estes indicadores têm sido de fundamental importância devido a sua utilização nos sistemas de planejamento como ferramenta de diagnóstico e monitoramento da qualidade ambiental.

Os indicadores devem então ser concebidos para serem utilizados como ferramentas para o planejamento e avaliação de políticas públicas, isto porque fortalecem as decisões e facilitam maior participação dos diversos grupos de interesse.

Como o desenvolvimento sustentável requer uma visão de mundo integrada, estes indicadores devem relacionar os diversos componentes da sustentabilidade, e seguir a proposta da Agenda 21 Global.

Neste ponto a presente pesquisa tem seu foco justificado, entendendo que a visão de desenvolvimento sustentável requer um trabalho nas interfaces entre os indicadores dos componentes da sustentabilidade, e que a definição destes indicadores demanda, portanto, estar embasada nas boas práticas de construção e na utilização de indicadores ambientais, econômicos e sociais, conforme discutido anteriormente.

No entanto, não se trata de descartar os indicadores existentes e seus respectivos sistemas associados, mas de estudar os pontos fortes e fracos dos indicadores ambientais existentes em seu emprego para um contexto a ser estudado sob o olhar da sustentabilidade.

Tal questão se deve pela necessidade de emprego de indicadores para a formulação de políticas e embasamento de discussões em contextos regionais e setoriais específicos que consideremos contextos globais.

Por meio do emprego de indicadores robustos para tal propósito é possível desenvolver estratégias setoriais e regionais em bases sustentáveis.

De forma crescente a idealização pelo desenvolvimento sustentável trouxe novas variáveis às arenas de discussão e tomada de decisão, e uma das motivações para tanto se 
deve à precariedade do atual modelo baseado na utilização de fontes não renováveis de energia e seus impactos no meio sócio-ambiental e reflexos no meio econômico.

As problemáticas acerca das matrizes energéticas estão cada vez mais no foco de diversas pesquisas de âmbito nacional e internacional. A partir da década de 1970, a preocupação com a poluição ambiental e com a emissão de gases na atmosfera têm fortalecido a produção comercial e uso dos biocombustíveis.

A busca de fontes energéticas alternativas e sustentáveis vem sendo estimulada devido às desvantagens do uso e dependência de fontes não renováveis, principalmente do petróleo e da poluição gerada por seus derivados, como o óleo diesel.

O bioetanol emerge deste cenário como um produto que fornece uma alternativa ao uso da gasolina, um dos principais subprodutos do petróleo, sendo considerado como uma fonte renovável e potencialmente sustentável.

Contudo, diversos estudos têm encontrado resultados que põem em cheque a viabilidade de emprego do etanol enquanto fonte energética sustentável, principalmente por seus impactos ao meio ambiente derivados do uso intensivo dos solos e recursos naturais, bem como de impactos relacionados à sua produção e consumo em componentes ambientais importantes como a água, o solo e a atmosfera.

O setor público, por meio de seus órgãos produtores e executores de políticas, desta forma, devem ter a capacidade de prover informações úteis à sensibilização - de tomadores de decisão, de gestores públicos e de empresas privadas, e da sociedade em geral, bem como produzir estratégias que conduzam ao desenvolvimento sustentável nestes aspectos.

Neste contexto, a Secretaria de Meio Ambiente do Estado de São Paulo surge, em esfera estadual, como responsável por produzir tais estratégias, uma vez que coordena, formula, aprova, executa, avalia e atualiza a Política Estadual de Meio Ambiente, além de articular e coordenar planos e ações relacionadas à área, bem como executar as atividades relacionadas ao licenciamento e à fiscalização ambiental.

Tendo em vista a conjuntura observada, estudos focados na proposição de uma estrutura cientificamente adequada de análise estratégica dos indicadores ambientais presentes na Secretaria do Meio Ambiente do Estado de São Paulo frente à discussão de sustentabilidade do etanol de cana-de-açúcar, são amplamente desejáveis, pois contribuem para a composição de estratégias de desenvolvimento sustentável em bases sólidas, por meio da avaliação e maximização da utilidade e do potencial informacional dos indicadores ambientais existentes na cena estadual. 


\subsection{Objetivos}

\subsubsection{Objetivo geral}

Propor uma estrutura de análise estratégica para indicadores ambientais das fontes de informações da Secretaria do Meio Ambiente do Estado de São Paulo frente à discussão da sustentabilidade do etanol de cana-de-açúcar.

\subsubsection{Objetivos específicos}

a) Caracterizar o componente ambiental (variáveis ambientais - solo, água e ar) nas suas interfaces com os outros componentes da sustentabilidade (social e econômico), sua importância e integração para a sustentabilidade.

b) Identificar princípios de boas práticas na construção e utilização de indicadores ambientais no contexto da sustentabilidade.

c) Discutir sobre o papel da informação ambiental no Estado de São Paulo como suporte à tomada de decisão na discussão da sustentabilidade.

d) Entender e discutir pontos de intervenção no componente ambiental do ciclo de vida do etanol de cana-de-açúcar, alinhado à visão integrada de sustentabilidade, desde a produção agrícola até o consumo. 


\section{MATERIAIS E MÉTODOS}

Seguindo as classificações previstas por Lakatos e Marconi (1992), esta pesquisa é classificada como descritiva, à medida que seu objetivo é indicar e discutir um método de avaliação dos pontos fortes e fracos dos indicadores ambientais das fontes de informações ambientais da Secretaria do Meio Ambiente do Estado de São Paulo - SMA/SP, com base em seus indicadores ambientais e na viabilidade de utilização destes para emprego na problemática da sustentabilidade da produção e consumo do etanol de cana-de-açúcar.

Neste sentido, a pesquisa busca aprofundar os conhecimentos sobre a discussão da sustentabilidade do etanol pela utilização de indicadores ambientais, configurando-se assim, também como uma pesquisa exploratória. (GIL, 2002).

O método de avaliação dos pontos fortes e fracos proposto pela pesquisa passa pela realização de um processo de validação de um conjunto de critérios para avaliação dos indicadores ambientais para emprego no contexto do etanol de cana-de-açúcar no Estado de São Paulo, num esforço descritivo-explicativo.

Como materiais e métodos de pesquisa estão inclusos pesquisa bibliográfica, análises documentais, consultas aos especialistas sob a forma de entrevistas e oficinas de discussão, e um estudo de caso, sendo este último um esforço de exemplificação da aplicabilidade do método descrito para a problemática explorada.

A seguir é apresentada a sistematização das principais etapas da pesquisa (Figura 2.1), sendo o detalhamento realizado a seguir sobre cada uma delas.

\subsection{Descrição das etapas metodológicas}

Esta pesquisa está configurada em seis blocos principais, os quais são discutidos pela revisão bibliográfica, levantamento/mapeamento, resultados e discussões. Tais blocos da pesquisa são:

a) Levantamento da base conceitual;

b) Caracterização do estudo de caso;

c) Mapeamento dos indicadores ambientais;

d) Seleção dos indicadores-chave;

e) Construção do método de análise;

f) Aplicação do método de análise.

Estes pontos estão esquematizados no fluxograma de atividades apresentado na Figura 2.1, como segue: 
Levantamento da Base Conceitual e Mapeamento dos Indicadores Ambientais da Secretaria do Meio Ambiente do Estado de São Paulo.

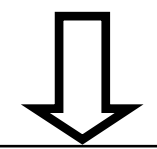

Levantamento e sistematização dos princípios de boas práticas de elaboração e utilização de indicadores.

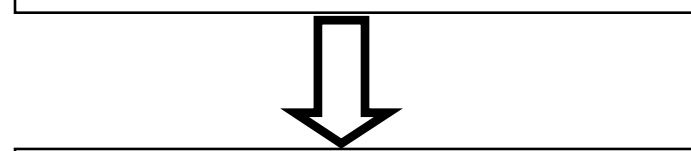

Discussão e consolidação dos critérios de análise por meio da Oficina de Especialistas.

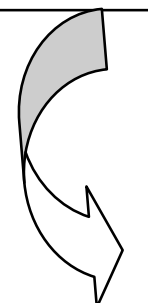

Aplicação da Análise em um indicador-chave (estudo de caso).

Consulta ao técnicoespecialista relacionado a este indicador ambiental.
Conjunto de indicadores-chave relacionados aos impactos negativos significativos do ciclo de vida do etanol.

Figura 2.1- Fluxograma das Principais Etapas da Pesquisa.

Como é possível observar pelo fluxograma, diversos pontos da pesquisa foram desenvolvidos de forma simultânea, aproveitando a complementaridade dos temas e a possibilidade de emprego de métodos e materiais para sua composição. Seguem nas próximas sessões as explicações detalhadas de cada uma destas etapas.

\subsection{Levantamento da Base Conceitual}

O bloco de base conceitual foi composto de uma revisão bibliográfica que será apresentada nos capítulos seguintes. Os capítulos 3, 4 e 5 trazem um arcabouço teóricoconceitual que relaciona três temas amplos, "Sustentabilidade", "Indicadores ambientais" e "Etanol de cana-de-açúcar".

Este levantamento de material bibliográfico serviu como base às discussões realizadas na forma de consultas a especialistas e na oficina de trabalho, tanto para o tema "indicadores 
ambientais" quanto para o tema do "etanol de cana-de-açúcar no Estado de São Paulo", e assim fortaleceu a validação da análise e sua discussão.

As principais bases de pesquisa para a revisão bibliográfica foram livros de leitura corrente, livros de referência, publicações em revistas e periódicos online e impressos diversos. Foram ainda consultadas publicações de órgãos reconhecidos internacionalmente no trato com os temas abordados, tais como: ONU (Organização das Nações Unidas)/ PNUMA (Programa das Nações Unidas para o Meio Ambiente), WCED (World Comission on Environment and Development) e CEPAL (Comissão Econômica para a América Latina e o Caribe).

A consulta considerou principalmente livros e periódicos digitais destacados pelos tesauros Capes, Science Direct, Scielo, SSRS, Elsevier, Scopus e outros.

Tais levantamentos trouxeram, além dos principais conceitos e entendimentos sobre os mesmos, reflexões sobre formas pelas quais tais temas têm sido abordados nos diferentes âmbitos (internacional e nacional), com especial concentração no estado de São Paulo. Os temas, bem como seu respectivo objetivo estão apresentados no Quadro 2.1.

\begin{tabular}{|l|l|}
\hline \multicolumn{1}{|c|}{ Tema } & \multicolumn{1}{c|}{ Objetivos alcançados } \\
\hline $\begin{array}{l}\text { Sustentabilidade } \\
\text { (Capítulo 3) }\end{array}$ & $\begin{array}{l}\text { Compreender e discutir o conceito de sustentabilidade, seu significado } \\
\text { e evolução. }\end{array}$ \\
\hline $\begin{array}{l}\text { Indicadores Ambientais } \\
\text { (Capítulo 4) }\end{array}$ & $\begin{array}{l}\text { Compreender a construção e utilização de indicadores ambientais e sua } \\
\text { validação no auxílio à informação e tomada de decisão. }\end{array}$ \\
\hline $\begin{array}{l}\text { Etanol de cana de açúcar } \\
\text { (Capítulo 5) }\end{array}$ & $\begin{array}{l}\text { Compreender e discutir os processos de produção e consumo, os } \\
\text { impactos ambientais negativos e posicionamento do ideário de } \\
\text { sustentabilidade, relacionados ao setor sucroalcooleiro. }\end{array}$ \\
\hline
\end{tabular}

Quadro 2.1 Detalhamento da Pesquisa Bibliográfica (Base Conceitual)

Como é possível observar pelo Quadro 2.1, cada capítulo contribui para a composição das bases sob as quais o estudo tem seus objetivos e análises assentadas.

No capítulo 3 da pesquisa discute-se o conceito de sustentabilidade alinhado à visão integrada. Tal fundamento buscou direcionar as análises e reflexões realizadas ao longo da pesquisa, tanto em seus estudos bibliográficos quanto em seus resultados e discussões sob o prisma do conceito de sustentabilidade trabalhado.

Dessa forma, o capítulo concebeu um delineamento acerca do tema sustentabilidade, suas várias dimensões, a evolução do conceito e da sua aplicação até atualmente.

No capítulo de indicadores ambientais (capítulo 4) são oferecidos os conceitos para a compreensão da importância destes para a sustentabilidade integrada e os princípios para sua construção, bem como validação para que estes tenham potencial de embasar as tomadas de decisões sob a óptica da sustentabilidade. 
Neste quarto capítulo consistiu-se uma revisão e análise crítica da literatura nacional e internacional disponível sobre indicadores ambientais como ferramentas importantes de planejamento e gestão, e suas interfaces com as diversas outras dimensões da sustentabilidade.

Ao mesmo tempo, esta etapa permitiu compreender sobre o progresso desta ferramenta no auxílio como informação para a tomada de decisão no que concerne a visão de sustentabilidade (integrada), servindo de base para discutir a produção e o consumo do etanol no Estado de São Paulo, tema apresentado no capítulo cinco.

Como trabalhado ao longo dos capítulos 3 e 4 a busca pela sustentabilidade deve ser considerada no âmbito das políticas públicas, considerando que o papel do estado neste sentido é o de prover as condições para tal propósito e fiscalizar a implementação das políticas públicas elaboradas.

Desta forma, a pesquisa realiza um estudo de caso junto ao principal órgão elaborador, executor e fiscalizador da política de meio ambiente no estado de São Paulo, qual seja a SMA, como apresentado na seção Caracterização do Estudo de Caso deste capítulo.

Nesta seção é demonstrada a estrutura da SMA/SP e sua importância para a sustentabilidade, o que embasa a sua escolha como recorte para o estudo de caso de acordo com os objetivos que se propõe a pesquisa.

Por fim, a pesquisa apresenta o etanol de cana-de-açúcar no capítulo 5, trazendo informações sobre seu histórico, ocupação e tendências futuras de produção no Estado de São Paulo, bem como características e impactos relacionados à sua produção e consumo. Com isto a pesquisa realiza uma reflexão sobre a importância de considerar a visão de sustentabilidade e empregar indicadores adequados para uma tomada de decisão fundamentada, com foco para o tema etanol no Estado de São Paulo.

Tal estruturação demonstrou que devido à relação intrínseca com os indicadores de sustentabilidade, é de inegável importância a seleção e validação de indicadores ambientais, devendo, a seleção e validação serem feitas por meio de um processo estruturado e coeso, capaz de garantir que as informações colhidas sejam relevantes e principalmente verídicas, para que sejam pertinentes na utilização acerca da situação problema em questão.

\subsection{Caracterização do estudo de caso}

O presente estudo se passa no cerne da efetivação da legislação que trata da Política Nacional do Meio Ambiente, considerando os órgãos ligados a ela em esfera estadual em sua origem e função. 
A Lei da Política Nacional de Meio Ambiente (Lei $n^{\circ}$ 6.938/81) constitui o marco legal brasileiro em meio ambiente e estabeleceu o Sistema Nacional de Meio Ambiente (SISNAMA), composto por órgãos ambientais federais, dos estados e dos municípios, responsáveis pela proteção, qualidade e melhoria do meio ambiente (BRASIL, 1981).

No ano de 1983, após a promulgação da lei que institui a Política Nacional do Meio Ambiente, o governo do Estado de São Paulo criou o Conselho Estadual do Meio Ambiente ${ }^{1}$ (CONSEMA) e três anos depois o Sistema Estadual do Meio Ambiente ${ }^{2}$ (SISEMA) o qual instituiu a Secretaria Estadual do Meio Ambiente - SMA (FURRIELA, 2002).

É através da articulação coordenada dos constituintes dos SISNAMA, da sociedade informada sobre questões envolvendo o meio ambiente e das ações de proteção ambiental estabelecidas pelo Conselho Nacional do Meio Ambiente (CONAMA), que se possibilita a efetividade e a eficiência do SISNAMA, competindo aos Estados e Municípios regionalizar as medidas provindas do SISNAMA, elaborando normas e padrões supletivos e complementares (BRASIL, 1981 e 1990).

Ao discorrer sobre o âmbito estadual, seu processo político e de gestão ambiental, encontra-se a Política Estadual do Meio Ambiente, a qual tem por objetivos (art. $2^{\circ}$ da Lei 9.509/97):

\footnotetext{
“(...) garantir a todos, da presente e das futuras gerações, o direito ao meio ambiente ecologicamente equilibrado, bem de uso comum do povo e essencial à sadia qualidade de vida, visando assegurar, no Estado, condições ao desenvolvimento sustentável, com justiça social, aos interesses da seguridade social e à proteção da dignidade da vida humana (...)" (SÃO PAULO, 1997).
}

Para execução destes objetivos, foi formado pela mesma lei o Sistema Estadual de Administração da Qualidade Ambiental (SEAQUA), que é constituído, conforme descrito pelo art. $7^{\circ}$ como:

\footnotetext{
“(...) órgãos e entidades da administração direta, indireta e fundacional do Estado e dos Municípios instituídos pelo Poder Público, responsáveis pela proteção e melhoria da qualidade ambiental, administração de recursos naturais, bem como as voltadas para manutenção e recuperação da qualidade de vida (...)" (SÃO PAULO, 1997).
}

A Secretaria de Estado do Meio Ambiente (SMA) opera como órgão central do SEAQUA, e, por conseguinte, opera como órgão seccional do SISNAMA (ver Figura 2.2), atuando como responsável pela elaboração, aprovação, execução, avaliação e atualização da

\footnotetext{
${ }^{1}$ Decreto $n^{\circ} 20.093 / 83$.

${ }^{2}$ Decreto ${ }^{\circ} 24.932 / 86$.
} 
Política Estadual de Meio Ambiente, bem como na formulação de normas que regulem o licenciamento e a fiscalização ambiental no estado, e que deverão ser, obrigatoriamente, atendidas por todos os órgãos e entidades executores do SEAQUA (SÃO PAULO, 2009b).

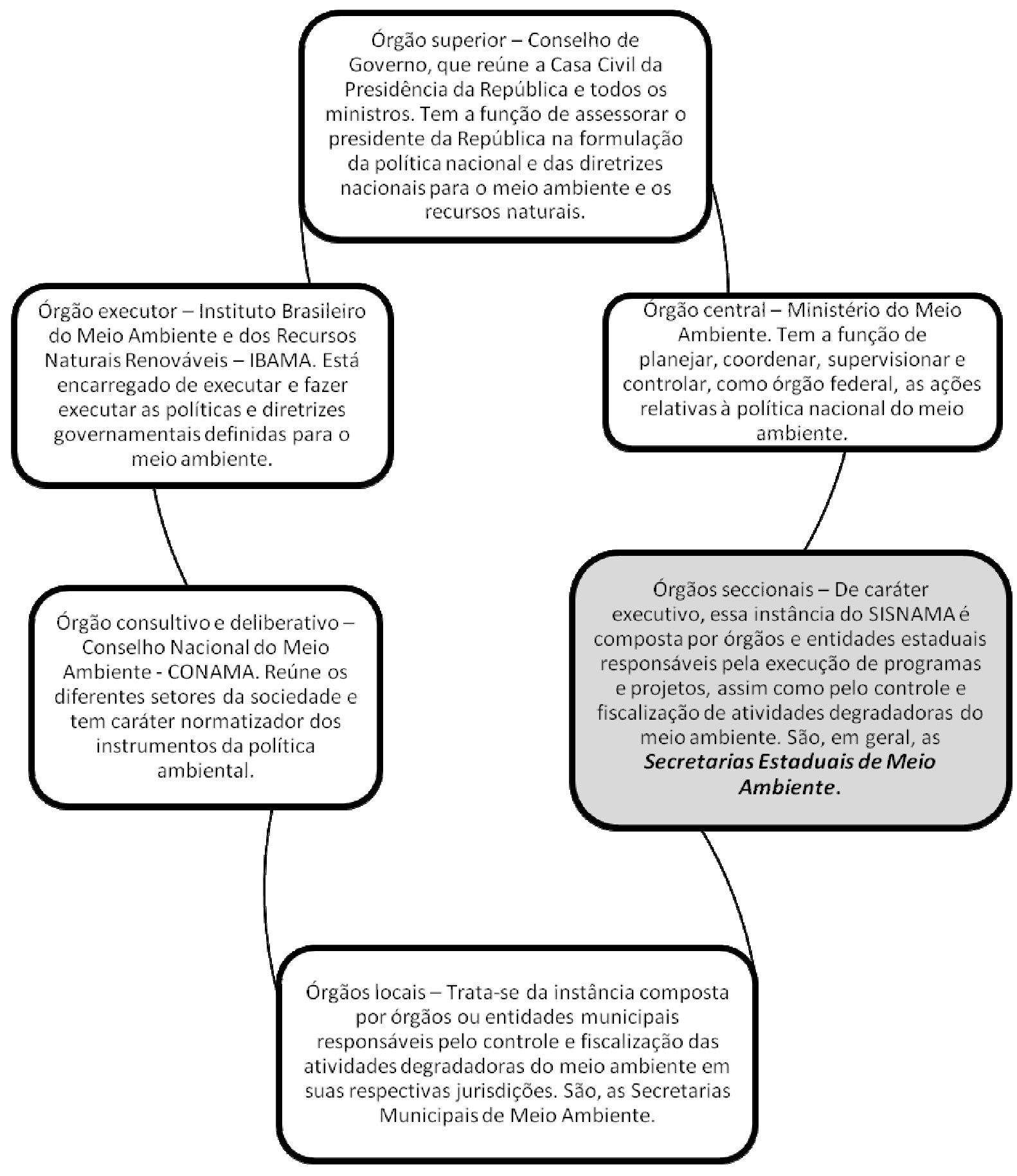

Figura 2.2- A Estruturação do SISNAMA e a Posição da Secretaria Estadual do Meio Ambiente e suas atribuições

Fonte: Baseado na Lei 6938/81 e suas alterações (Lei 8028/90 e Lei 7804/89).

Não obstante, a SMA é responsável por fomentar a educação ambiental, normatização, controle, proteção, conservação e recuperação dos recursos naturais (SÃO PAULO, 2009b). 
As funções e importância da SMA dentro do SISNAMA e SEAQUA ao ser o responsável, em escala estadual, em realizar o papel de desenvolvedor e executor da Política Estadual do Meio Ambiente, somado a sua função de monitoramento e fiscalização da situação ambiental qualifica-a como alvo importante para esta pesquisa.

Destaca-se adicionalmente que a adequação da SMA ao estudo é também derivada por esta possuir experiência e uma estrutura de coleta, análise e divulgação de indicadores ambientais e devido ao seu papel no processo de gestão da informação ambiental no Estado.

Tais motivos embasam o recorte do mapeamento e análise dos indicadores ambientais produzidos e estruturados pela Secretaria de Meio Ambiente do Estado de São Paulo e por suas instituições vinculadas.

Para a SMA/SP, o uso de indicadores faz-se necessário por três motivos (SMA, 2009):

i. Para comparação dos dados do Estado de São Paulo com os de outras regiões brasileiras, bem como, com de outros países;

ii. Para a análise, elaboração, monitoramento e avaliação de políticas públicas;

iii. Para possibilitar a comunicação com o público interessado na área ambiental.

O intuito da análise é discutir a pertinência dos indicadores ambientais, de responsabilidade exclusiva da SMA, em monitorar os principais impactos ambientais negativos gerados pela produção e consumo do etanol de cana-de-açúcar no estado, visto que estes indicadores devem ser elaborados e utilizados rumo à sustentabilidade.

Desde o surgimento da SMA em 1986 e mesmo com sua reestruturação (em 2008 através do Decreto 53.027/2008 e posteriormente aprimorado pelo Decreto 54.653/2009) o seu propósito tem sido promover preservação, melhoria e recuperação da qualidade ambiental (SMA, [entre 1996 e 2011]; SÃO PAULO, 1973).

Até a sua criação, a CETESB era o único órgão delegado do Governo do Estado de São Paulo na área ambiental, porém sua atuação só se observava no campo de controle de poluição das águas e da tecnologia de engenharia sanitária.

Com objetivos e atividades mais abrangentes, tais como fiscalização e controle da qualidade do ar, água e solo a CETESB passou por uma alteração em sua denominação, passando de Centro Tecnológico de Saneamento Básico para Companhia de Tecnologia e Saneamento Ambiental, tendo mantida sua sigla (CETESB, 2009; SÃO PAULO, 2009a).

Atualmente, com a Lei 13.542 de 8 de maio de 2009, criou-se a "Nova CETESB", com uma nova denominação sendo oficialmente Companhia Ambiental do Estado de São Paulo e novas atribuições, principalmente no processo de licenciamento ambiental no Estado, a qual é 
órgão centralizador. Com a mudança, extingue o antigo modelo de comando e controle e adota a agenda da gestão ambiental dentro da óptica da sustentabilidade, sendo uma das instituições componentes da SMA (CETESB, 2009; SÃO PAULO, 2009a).

De acordo com o Decreto 54.653/2009, a estrutura reorganizada da Secretaria Estadual do Meio Ambiente é composta basicamente por órgãos colegiados, unidades técnicas e entidades vinculadas (ver Figura 2.3) (SMA, 2009; SÃO PAULO, 2009b).

Dessa maneira, os departamentos, coordenadorias e núcleos atuam inseridos em cada unidade (agentes técnicos) da SMA para desempenhar as atividades competentes à sua pasta. São agentes técnicos da SMA e suas atribuições principais (SMA, 2009):

- Coordenadoria de Biodiversidade e Recursos Naturais - CBRN;

Tem suas atribuições relacionadas principalmente à fiscalização, à proteção e à recuperação dos recursos naturais e da biodiversidade.

- Coordenadoria de Educação Ambiental - CEA;

Executa, principalmente, a Política Estadual de Educação Ambiental (Lei n ${ }^{\circ}$ 12.780, de 30 de novembro de 2007).

- Coordenadoria de Planejamento Ambiental - CPLA;

Essencialmente, a CPLA planeja o zoneamento de áreas sob proteção especial ou de interesse ambiental estratégico; elabora o planejamento ambiental estratégico do uso de recursos ambientais, visando o desenvolvimento sustentável e assegura e disponibiliza informações ambientais, pretendendo apoiar à tomada de decisão para a gestão ambiental.

- Coordenadoria de Recursos Hídricos - CRHi;

Dispõe e supervisiona o Sistema Integrado de Gerenciamento de Recursos Hídricos SIGRH e a aplicação dos instrumentos da Política Estadual de Recursos Hídricos.

- Instituto de Botânica - IBt;

É instituição de pesquisas científicas na área da botânica da SMA, com a missão de subsidiar a política ambiental do Estado de São Paulo.

- Instituto Florestal - IF;

Além de pesquisas, o instituto realiza o monitoramento da vegetação natural e do reflorestamento em todo o Estado.

- Instituto Geológico - IG;

Tem como principal missão realizar de pesquisas científicas em geociências e meio ambiente, desenvolvendo trabalhos relacionados ao planejamento territorial, uso e ocupação do solo, entre outros, gerando assim, informação necessária às políticas públicas no Estado. 
A SMA, de acordo com o mesmo decreto, n.54.653, de 06 de agosto de 2009 conta ainda com as seguintes entidades vinculadas (SMA, 2009; SÃO PAULO, 2009b):

a) Fundação para a Conservação e a Produção Florestal do Estado de São Paulo;

Conhecida somente como Fundação Florestal, o seu objetivo maior é apoiar, promover e executar ações que colaborem para a conservação, manejo e ampliação das florestas de proteção e produção do Estado de São Paulo, e para isso realiza parcerias com órgãos governamentais e instituições da sociedade civil.

b) Fundação Parque Zoológico de São Paulo;

A principal contribuição é na realização de programas de pesquisa científica e conscientização ambiental da população através dos visitantes.

c) CETESB - Companhia Ambiental do Estado de São Paulo;

Agência do Governo do Estado de São Paulo responsável pela fiscalização, monitoramento e licenciamento de atividades causadoras de poluição, com objetivos, entre outros, de gerar indicadores e monitorar o desempenho nas diversas áreas de interesse ambiental e ainda, organizar e disponibilizar estes indicadores (informações) sobre a qualidade ambiental à sociedade.

Cada um destes agentes está organizado e administrado em função de sua forma de administração que pode ser centralizada, descentralizada ou mesmo por meio de um órgão colegiado. A estrutura da SMA, seus agentes envolvidos, bem como a forma de administração dos mesmos pode ser observada no organograma apresentado na Figura 2.3

Por toda sua estruturação a SMA colhe, organiza e sistematiza informações precisas referentes aos aspectos de sua responsabilidade, com intuito de obter um quadro da condição ambiental do estado, divulgando estas informações à sociedade por meio de Relatórios de Qualidade Ambiental - RQAs.

A importância da SMA é evidenciada principalmente quando se observam, dentre os 22 princípios da Política Estadual do Meio Ambiente (SÃO PAULO, 1997), os princípios de:

- Planejamento e fiscalização do uso dos recursos ambientais; e

- Informação da população sobre a condição de poluição e qualidade do meio ambiente, das situações de risco à saúde e ao meio ambiente, relacionadas a desastres e a substâncias tóxicas encontradas nos alimentos, na água, no solo, no ar.

Ao mesmo tempo, a Política Estadual do Meio Ambiente (Lei 9.509/97) coloca em seu art. 4 que visará: 
“[...] à conscientização pública para a preservação do meio ambiente, através da divulgação de relatórios anuais sobre a qualidade ambiental no Estado, da divulgação de dados e informações ambientais e da promoção de campanhas educativas".

E acrescenta com o Art. 16, que:

“\$ $1^{\circ}$. A Secretaria de Estado do Meio Ambiente publicará no Diário Oficial do Estado até o dia 31 de março de cada ano a consolidação dos relatórios mencionados neste artigo em um "Relatório Anual da Qualidade Ambiental" no Estado de São Paulo, do qual constarão, também, as avaliações e recomendações, notadamente, quanto a revisão de prioridades, programas e ações, recursos financeiros, tecnologias e participação comunitária no âmbito do SEAQUA.

$\S 2^{\circ}$. O Relatório Anual, referido no parágrafo anterior deverá ser enviado ao CONSEMA, para as providências de sua alçada e apreciação."

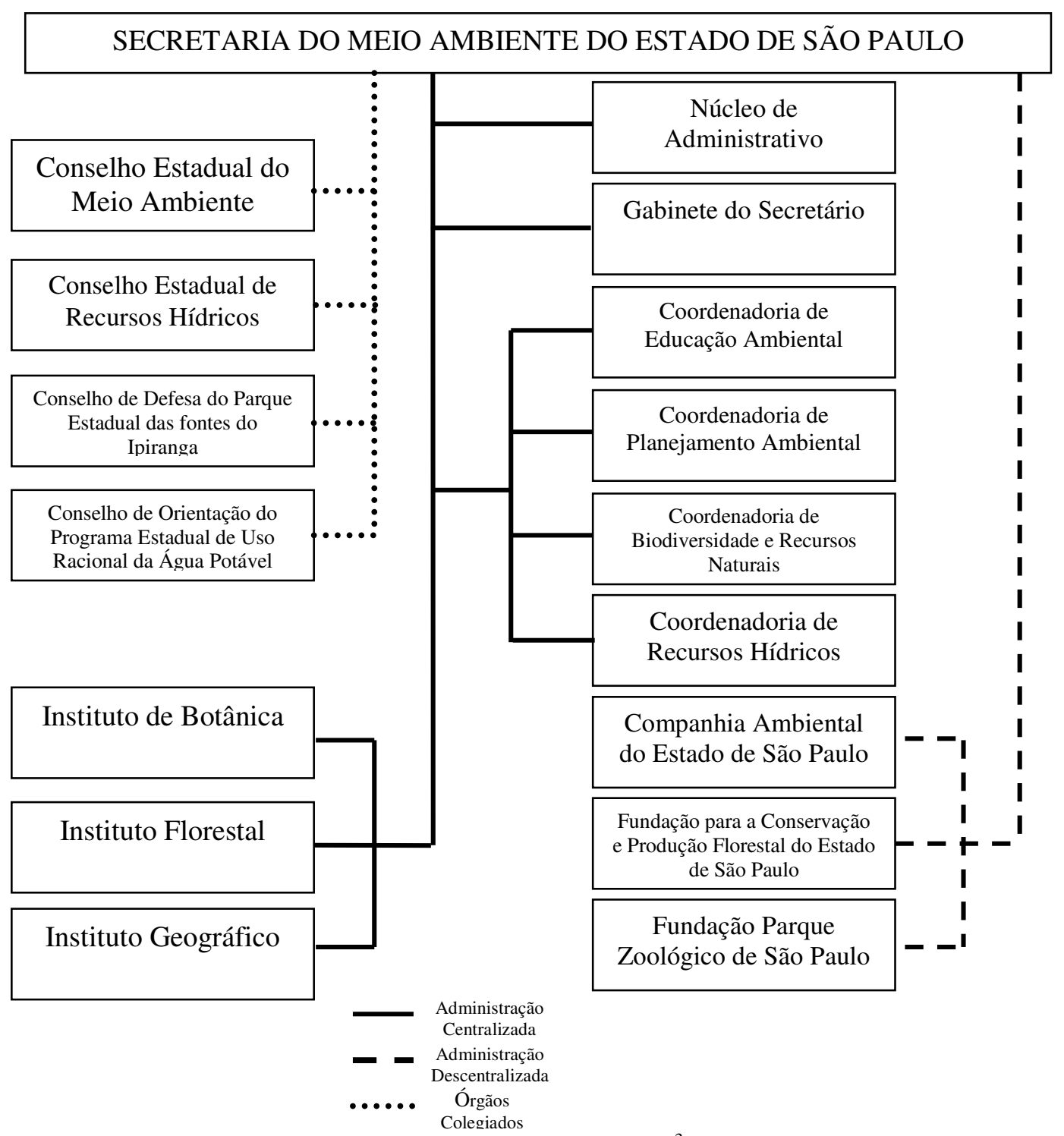

Figura 2.3- Estrutura Organizacional da Secretaria do Meio Ambiente ${ }^{3}$ - SMA/SP Fonte: SMA (2009).

\footnotetext{
${ }^{3}$ Este organograma decorre do Decreto No 54.653, de 6 de agosto de 2009 que Reorganiza a Secretaria do Meio Ambiente - SMA e dá providências correlatas.
} 
Desta forma, é clara a necessidade de ferramentas que possibilitem ao mesmo tempo avaliar a situação presente, projetar cenários futuros, comunicar e integrar a sociedade sobre o processo de tomada de decisão dentro do contexto ambiental, em outras palavras, a necessidade de utilizar indicadores de qualidade ambiental como tais ferramentas.

Sendo assim, para atingir os objetivos desta pesquisa foram mapeados os indicadores ambientais sistematizados, divulgados nos Relatórios Ambientais produzido pela SMA e suas entidades vinculadas, e aplicada a análise de qualidade para um deles, o IQA - Índice de Qualidade de Água, como aplicação para o estudo de caso.

Este mapeamento serve de base para a proposta metodológica de avaliação dos pontos fortes e fracos dos indicadores ambientais no cumprimento de sua função primordial, qual seja indicar a situação atual e projeções futuras do panorama ambiental, auxiliando no alcance do desenvolvimento sustentável através do suporte na formulação e avaliação de políticas públicas.

No caso específico da pesquisa este contexto tem como cenário a discussão da possibilidade de utilização dos indicadores ambientais da SMA no debate sobre a sustentabilidade do etanol de cana-de-açúcar no Estado de São Paulo.

\subsection{Mapeamento dos indicadores ambientais}

Considerando a grande quantidade e variabilidade de informações ambientais no Estado de São Paulo, dada a repartição de competências institucionais e a descentralização da gestão ambiental no país, seria inviável e improdutivo mapeá-los na totalidade, ainda que restritamente aos temas ar, água e solo.

Por este motivo, optou-se por testar o procedimento metodológico de mapeamento nos indicadores ambientais físico-químicos pertinentes aos componentes atmosfera, solo e água, consequentemente suas respectivas fontes de informação a partir dos Relatórios de Qualidade Ambiental (RQAs) produzidos pela Secretaria do Meio Ambiente, com a finalidade de apresentar um produto útil e factível.

Os indicadores formulados pela SMA são sistematizados e divulgados por meio de RQAs, instrumentos de política ambiental que têm possibilitado um arranjo dos dados e informações ambientais.

Nesta pesquisa, tais relatórios foram considerados como ponto norteador para o mapeamento dos indicadores ambientais a serem discutidos (Quadro 2.2), sendo trabalhados aqueles de propriedade físico-química voltados aos componentes ambientais água, solo e ar, produzidos e divulgados pela SMA e suas entidades vinculadas. 
Mesmo que alguns destes relatórios não tenham sido utilizados para o mapeamento por questão de não contemplarem o recorte da pesquisa, suas informações passaram por análise indiretamente, uma vez que estas se encontram inseridas nos outros materiais mapeados.

\begin{tabular}{|c|c|c|c|c|}
\hline $\mathrm{N}^{\mathrm{o}}$ & $\begin{array}{l}\text { RQAs publicados } \\
\text { pela SMA: }\end{array}$ & $\begin{array}{l}\text { Instituição da } \\
\text { SMA responsável } \\
\text { pelo RQA }\end{array}$ & $\begin{array}{c}\text { Componente } \\
\text { Ambiental } \\
\text { abordado }\end{array}$ & $\begin{array}{l}\text { Situação para o Mapeamento dos } \\
\text { indicadores ambientais. }\end{array}$ \\
\hline 1 & $\begin{array}{c}\text { Relatório Estadual } \\
\text { de Qualidade das } \\
\text { Águas Interiores }\end{array}$ & CETESB $^{1}$ & Água & Documento utilizado. \\
\hline 2 & $\begin{array}{c}\text { Painel de Qualidade } \\
\text { Ambiental }\end{array}$ & CPLA $^{2}$ & Misto & Documento utilizado. \\
\hline 3 & $\begin{array}{c}\text { Relatório de } \\
\text { Qualidade das } \\
\text { Águas Subterrânea }\end{array}$ & CETESB & Solo/Água & Documento utilizado. \\
\hline 4 & $\begin{array}{l}\text { Relatório- } \\
\text { Avaliação de } \\
\text { Compostos } \\
\text { Orgânicos da } \\
\text { Queima de Palha }\end{array}$ & $\begin{array}{l}\text { CETESB e } \\
\text { Departamento de } \\
\text { Qualidade } \\
\text { Ambiental } \\
\text { (inserido na } \\
\text { CPLA) }\end{array}$ & $\mathrm{Ar}$ & $\begin{array}{l}\text { Documento não utilizado*- Pesquisa com } \\
\text { objetivo de formular um método de } \\
\text { investigação da qualidade do ar. Este } \\
\text { estudo foi realizado em conjunto com a } \\
\text { Universidade de Tübingen, Alemanha e } \\
\text { aplicado na região de Araraquara. }\end{array}$ \\
\hline 5 & $\begin{array}{c}\text { Relatório Qualidade } \\
\text { do Ar no Estado de } \\
\text { São Paulo }\end{array}$ & CETESB & $\mathrm{Ar}$ & Documento utilizado. \\
\hline 6 & $\begin{array}{c}\text { Resolução e } \\
\text { Relação de Áreas } \\
\text { Saturadas- } \\
\text { Municípios } \\
\text { Monitorados } \\
\end{array}$ & SMA & $\mathrm{Ar}$ & $\begin{array}{l}\text { Documento não utilizado. Informações } \\
\text { inseridas nos outros relatórios utilizados } \\
\text { para o mapeamento. De qualquer forma o } \\
\text { material não é um RQA. }\end{array}$ \\
\hline 7 & $\begin{array}{c}\text { Gerenciamento de } \\
\text { Áreas } \\
\text { Contaminadas }\end{array}$ & CETESB & Solo/ água & $\begin{array}{l}\text { Documento não utilizado. Informações } \\
\text { inseridas nos outros relatórios utilizados } \\
\text { para o mapeamento. De qualquer forma o } \\
\text { material não é um RQA. (O mesmo está na } \\
\text { aba do site, somente como dados } \\
\text { tabelados.) }\end{array}$ \\
\hline 8 & $\begin{array}{l}\text { Relatório Anual de } \\
\text { Qualidade } \\
\text { Ambiental do } \\
\text { Estado }\end{array}$ & CPLA & Misto & Documento utilizado. \\
\hline 9 & $\begin{array}{l}\text { Relatório Etanol } \\
\text { Verde }\end{array}$ & $\begin{array}{l}\text { Departamento de } \\
\text { Desenvolvimento } \\
\text { Sustentável } \\
\text { (inserido no } \\
\text { CBRN }^{3} \text { ) }\end{array}$ & Misto & $\begin{array}{l}\text { Documento não utilizado. Informações } \\
\text { inseridas nos outros relatórios utilizados } \\
\text { para o mapeamento. De qualquer forma o } \\
\text { material não é um RQA e sim um projeto } \\
\text { estratégico de metas e ações. }\end{array}$ \\
\hline 10 & $\begin{array}{l}\text { Relatório Anual de } \\
\text { Situações dos } \\
\text { Recursos Hídricos }\end{array}$ & $\mathrm{CRHI}^{4}$ & Água & Documento utilizado. \\
\hline \multicolumn{5}{|c|}{$\begin{array}{l}{ }^{1} \text { CETESB - Companhia Ambiental do Estado de São Paulo. } \\
2 \text { CPLA - Coordenadoria de Planejamento Ambiental. } \\
{ }^{3} \text { CBRN - Coordenadoria de Biodiversidade e Recursos Naturais. } \\
{ }^{4} \text { CRHI - Coordenadoria de Recursos Hídricos. } \\
\text { * Para os documentos não utilizados foi destacada a justificativa. } \\
\text { Quadro 2.2- Relatórios utilizados para o mapeamento dos indicadores ambientais }\end{array}$} \\
\hline
\end{tabular}


É elevado o número de indicadores ambientais disponíveis nos RQAs, sendo oriundos de diferentes instituições. Desta forma foi realizado um recorte nas instituições componentes da SMA que possibilitasse um conjunto de indicadores relevantes para a análise, aqui chamado de indicadores-chave. A listagem destes indicadores foi realizada por planilhas eletrônicas do software Microsoft Office Excel ${ }^{\circledR}$.

\subsection{Seleção dos indicadores-chave}

De todos os indicadores mapeados (410 indicadores), foram selecionados aqueles cujas características se aproximavam do contexto da análise, ou seja, que representassem os componentes ambientais água, solo e ar no que concerne às características físico-químicas e ainda, que pudessem ter relação com a temática do etanol de cana-de-açúcar.

Tal triagem deu origem a um conjunto de indicadores específico para a análise e discussão, aqui chamado de indicadores-chave, sendo a sua composição baseada em alguns quesitos:

i. O indicador deve ser produzido por uma das instituições componentes da SMA.

Esta dependência se faz necessária uma vez que o objetivo desta pesquisa é investigar o quanto os indicadores ambientais deste órgão governamental conseguem cobrir os principais impactos ambientais negativos gerados pela produção e consumo do etanol de cana-de-açúcar no estado, e, a capacidade destes indicadores em debater sobre a sustentabilidade do etanol.

ii. Deve haver uma relação entre a mensuração realizada pelo indicador e os impactos negativos significativos da atividade sucroalcooleira, especificamente o etanol, nos componentes ambientais (ar, solo e água).

Para o alcance destes impactos significativos, foi formulada uma listagem de impactos ambientais negativos referentes ao ciclo de vida do etanol de cana-de-açúcar. Porém, devido a sua extensão e de acordo com o objetivo da pesquisa não foram consideradas algumas partes e seus respectivos impactos (Figura 2.4).

Os impactos da atividade canavieira foram baseados na literatura e a listagem foi obtida por meio de triagem teórica. Este método, de acordo com Heink e Kowarik (2010), já tem sido utilizado por vários trabalhos e explora a grande dimensão ao longo de um tema no qual a discussão e suas propriedades variam, até o ponto em que não há variação de um novo conceito ou das propriedades do tema, chegando à saturação teórica.

Como é possível observar na Figura 2.4 a pesquisa está delimitada com enfoque nas fases internas dos processos produtivos (agrícola e industrial), bem como na fase de 
distribuição e consumo do etanol, seja sob a forma de aditivo à gasolina, ou mesmo sob a forma de etanol hidratado.

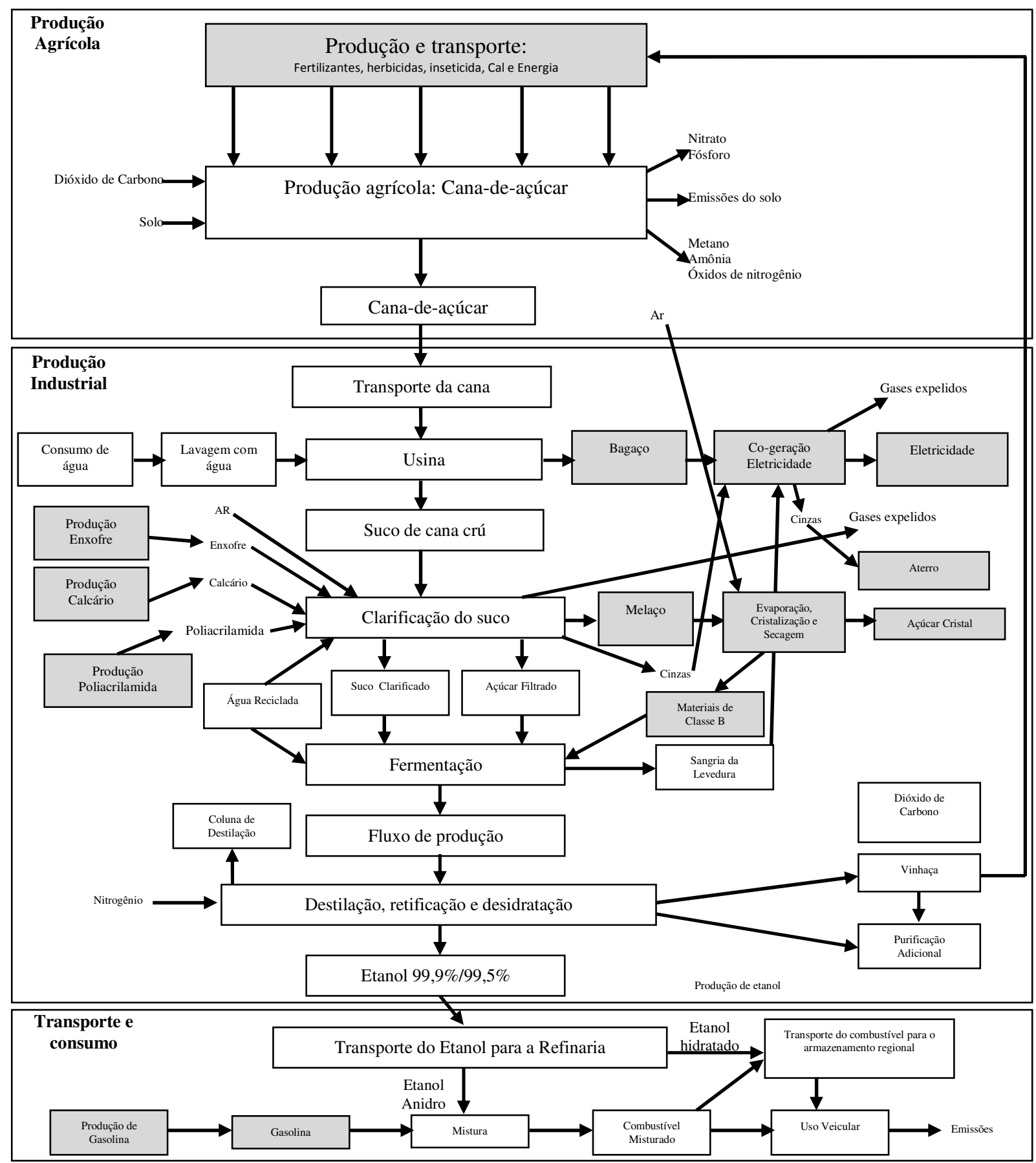

Partes desconsideradas na análise por não fazerem parte do recorte da pesquisa e/ou estarem fora do ciclo de vida do etanol.

Figura 2.4- Fases e etapas do ciclo de vida do etanol de cana-de-açúcar consideradas pela pesquisa Fonte: Baseado em Luo et al. (2008).

A triagem permitiu identificar uma grande quantidade de impactos tanto positivos quanto negativos do ciclo de vida do etanol de cana-de-açúcar. Alguns excessivamente pontuais outros muito dependentes das especificidades do local, etc., e por esses motivos, 
optou-se em listar aqueles impactos negativos considerados mais relevantes pelas bibliografias e confirmá-los com especialistas da área ambiental.

Para isto foi composto um quadro de impactos negativos significativos, de cadeia causal, o qual oferece uma representação das atividades (causas), os mecanismos/processos (aspectos) e as consequências negativas (impactos negativos diretos e indiretos de $1^{\mathrm{a}}$ ordem) da produção e consumo do etanol.

De acordo com Sánchez (2008, p. 111) os impactos ambientais significativos são explicados como “[...] tudo aquilo que tem um significado; é sinônimo de expressivo; considerável, suficientemente grande; importante."

Ao mesmo tempo o autor expõe que a definição não resolve muito o problema da subjetividade do termo, uma vez que a importância atribuída depende dos valores e percepções das pessoas.

Neste ponto está fundamentada a utilização da consulta aos especialistas, considerando a capacidade de auxílio à consolidação dos impactos, reduzindo o viés do pesquisador e possibilitando a análise e confirmação deste método de seleção por diferentes expertises.

Assim, foram verificados e legitimados pelos especialistas ambientais os impactos negativos significativos da atividade sucroalcooleira, e apontados aqueles indicadores que possuíssem relação com estes impactos, ou seja, que tivessem maior relevância para apoiar a discussão da sustentabilidade do etanol.

Os resultados de tais consultas trouxeram maior credibilidade para a escolha dos indicadores-chave e estão apresentados no capítulo de Análise e Discussão dos Resultados de forma a melhorar o entendimento sobre a sua aplicação.

Estas consultas diretas aos especialistas foram feitas no formato de entrevistas semiestruturadas com intuito de tornar eficaz o método e os resultados. As entrevistas semiestruturadas de acordo com Boni e Quaresma (2005) têm as seguintes vantagens:

a) $\mathrm{O}$ pesquisador segue um conjunto de questões previamente definidas, mas ele o faz em um contexto muito semelhante ao de uma conversa informal, dirigindo a discussão para o assunto que o interessa, podendo esclarecer questões que não ficaram claras e adicionar perguntas, obtendo assim um direcionamento maior para o tema;

b) Elasticidade quanto à duração, possibilitando uma análise mais profunda sobre determinados assuntos, e; 
c) Interação entre o entrevistador e o entrevistado, favorecendo respostas espontâneas, maior abertura, proximidade, o que permite ao entrevistador tocar em assuntos mais complexos e delicados.

As entrevistas semiestruturadas, aqui utilizadas como método para consultar os especialistas ambientais, possuem o formato de matriz, onde relaciona tópicos de discussão com os indicadores ambientais da SMA/SP.

Foram realizadas triagens dos indicadores, como etapa de preparação para a entrevista. O produto desta triagem foi um quadro de indicadores que apresentava, de acordo com a sua composição e seguindo as indicações da bibliografia sobre o impacto, relação com os impactos negativos significativos.

Durante as entrevistas, os especialistas foram questionados sobre a relevância dos indicadores para discutir a sustentabilidade do etanol com vistas aos impactos, isto sob o prisma dos diversos tópicos apresentados (ver APÊNDICE A).

As questões foram trabalhadas pelos especialistas através de uma escala de pontuação de 0 a 5, onde estes entrevistados atribuíram, segundo sua expertise, pontos a cada indicador, considerando que a atribuição de 0 configura o indicador como sem qualquer relevância e 5 um indicador com máxima/total relevância para o tópico sob análise.

Nas entrevistas aos especialistas foram incorporadas informações prévias sobre a qualificação destes indicadores e seu potencial de utilização para o contexto do etanol. Estas informações tiveram como objetivo principal maximizar o conhecimento sobre os indicadores para conferir maior robustez à análise dos pontos fortes e fracos destes indicadores e somá-los a discussão dos resultados. Contudo, como expresso anteriormente, o objetivo das consultas foi promover a validação dos impactos negativos significativos e paralelamente a escolha do indicador para futura análise (primeiro tópico da entrevista).

Após as consultas a pesquisa realizou uma nova triagem destes indicadores considerando apenas aqueles cuja pontuação atribuída pelos especialistas se mostrou igual ou superior a 3 pontos no grau de relevância.

Os especialistas consultados são parceiros nacionais envolvidos no projeto de pesquisa $\mathrm{n}^{\circ}$ 2008/58033-3, financiado pelo Programa BIOEN FAPESP, denominado "O doce e o amargo da cana-de-açúcar: estudo estratégico integrado de políticas públicas aplicadas à produção de etanol de cana-de-açúcar no Brasil". Apelidado por AISe ao se referir a uma Avaliação Integrada de Sustentabilidade do etanol de cana-de-açúcar, integra vários trabalhos voltados ao contexto do etanol, sendo esta pesquisa um deles. 


\subsection{Construção do método de análise}

Uma vez conseguido o conjunto de indicadores-chave relevantes ao contexto do etanol, a pesquisa prosseguiu no objetivo de formar uma base de análise baseada em boas práticas na construção e uso de indicadores inseridos na visão da sustentabilidade. Desta forma, foram buscados e listados os requisitos colocados pela bibliografia, como essenciais para o perfil de um indicador ambiental ideal, com visão e aplicação para o questionamento sobre sustentabilidade com aplicação para o etanol de cana-de-açúcar.

Para isso, foram olhados experiências e guias sobre o tema de boas práticas em indicadores, o que originou a lista de critérios a serem utilizados na análise. Durante este processo foram encontradas muitas definições, sobreposições conceituais e interpretações de acordo com as distintas experiências.

A oficina de especialistas realizada foi importante neste sentido, ao servir para composição de um consenso conceitual e alinhamento dos pontos de vista. Tal oficina proporcionou reflexões e compartilhamento de conhecimento sobre a relevância e modo de utilização destes critérios como base de análise.

Sendo assim, foram listados no primeiro momento, 29 critérios de acordo com as bibliografias consultadas, os quais apresentavam peculiaridades já citadas no parágrafo anterior. Como forma de depuração destes critérios foi realizada uma pré-oficina com a equipe interna do projeto AISe para formação de consenso sobre quais definições estavam sobrepostas e ambíguas com intuito de obter um material mais transparente e objetivo a ser debatido na oficina de especialistas.

Desta pré-oficina foram eliminados 10 critérios dos 29, ficando para a oficina 19 critérios que foram sistematizados em uma tabela (ver APÊNDICE B), a qual foi utilizada para uma dinâmica em grupo dentro da oficina de especialistas.

Cada grupo formado por uma equipe de especialistas discutiram os critérios com seus membros, utilizando a estrutura das tabelas para validar o critério, bem como realizar críticas e sugestões de adaptações.

Ao final, todos os grupos apresentaram suas sugestões para composição de um consenso com contribuição por meio de uma discussão aberta de todos os presentes na oficina. Tal oficina contou com 16 participantes com formações distintas, que trabalham com a área ambiental, planejamento, indicadores e sustentabilidade, dos quais 13 são parceiros do grupo Aise e 3 foram convidados.

Por fim, a oficina trouxe como resultado os critérios que deveriam ser utilizados para análise estratégica dos indicadores ambientais, ou seja, de pontos fortes e fracos no escopo da 
sustentabilidade com recorte para o etanol de cana-de-açúcar, e ainda como resultado, foram desenhados pela oficina cada procedimento a ser realizado para verificar a contemplação de cada critério de análise.

\subsection{Aplicação do método de análise}

Como resultado das oficinas observou-se que muitos dos critérios dependiam de consultas a especialistas que fossem peritos na elaboração e uso de cada indicador, ou seja, um conhecedor da história do indicador e de detalhes técnicos para avaliações mais concentradas.

Neste sentido, considerando a limitação dado o elevado número de indicadores levantados, foi selecionado um indicador para aplicação do método construído ao longo da pesquisa e validado pela oficina, qual seja o Índice de Qualidade da Água (IQA).

Tal análise se deu através de uma nova consulta em formato de entrevista semiestruturada (ver APÊNDICE C) ao especialista perito no IQA.

As adaptações e modificações dos critérios propostos na oficina estão apresentadas no capítulo Análise e Discussão dos Resultados, e ainda a sua aplicação como método da análise.

Os critérios foram aplicados por meio de investigação das informações contidas nos RQAs e, quando pertinente, confrontadas com as respostas do perito.

Para apresentação e melhor entendimento dos resultados a pesquisa elaborou uma matriz denominada Critérios de Análise - Pontos Fortes e Fracos dos Indicadores Ambientais, já que este método pode ser aplicado para um conjunto de indicadores, possibilitando a comparação dos seus resultados baseados nestes critérios de excelência, e assim, trazendo uma visão crítica de quantos e quais indicadores contemplaram estes critérios, e ainda quais foram estes critérios.

Todavia, nesta pesquisa optou-se por fazer exemplificar a análise através da aplicação para um único índice e com isso discutir as vantagens e desvantagens do método para responder ao objetivo da pesquisa.

Por fim, para dar maior clareza às informações discutidas sobre o índice analisado a pesquisa recorreu a uma análise SWOT. Este tipo de análise é utilizada principalmente com o objetivo de prover aos decisores informações relacionadas a fatores importantes de uma determinada situação, tendo como produto a redução das incertezas e formulação de estratégias (MARCELINO, 2004).

O termo SWOT resulta da conjugação das iniciais das palavras do inglês:

- Strengths (forças): vantagens do aspecto analisado frente ao cenário observado; 
- Weaknesses (fraquezas): fragilidades do aspecto que podem prejudicar os resultados do cenário projetado;

- Opportunities (oportunidades): possibilidades de melhoria presentes no ambiente que podem potencializar o aspecto; e

- Threats (ameaças): perigos provenientes do ambiente que podem comprometer o desempenho do aspecto caso determinadas ações sejam implementadas;

A SWOT vem sendo utilizada em larga escala no processo de gestão para a formulação de planejamentos e implementação de políticas públicas, bem como em avaliações ambientais (CGEE, 2009).

Entende-se, por fim, que o conjunto de etapas metodológicas proposto pela pesquisa foi capaz de garantir que os seus objetivos fossem atingidos, isto é, capaz de formular um adequado método de análise e qualificação de indicadores ambientais, observando as boas práticas voltadas para a sustentabilidade trazidas pela literatura.

Estes métodos se mostraram eficientes para o contexto do etanol de cana-de-açúcar. Contudo, entende-se que, por sua flexibilidade de aplicação, tal conjunto metodológico serve de guia de referência para trabalhos que busquem realizar uma análise da adequabilidade de indicadores ambientais e sua utilização no debate da sustentabilidade de uma atividade, independente de qual seja esta. 


\section{SUSTENTABILIDADE}

Por muitos existe a contestação do conceito de sustentabilidade, ou porque ele é complexo, subjetivo ou ambíguo (LÉLÉ, 1991). No entanto, mesmo com interpretações divergentes, existe uma série de pontos em comum que possibilita que a noção de sustentabilidade possa ser colocada em prática.

Ao mesmo tempo, sua heterogeneidade representa uma vantagem devido a flexibilidade dinâmica e aberta de poder ser adaptado e utilizado em diversas situações contextuais e temporais. Sendo assim, é possível adequar o uso destes conceitos às peculiaridades das múltiplas esferas (governamentais, sociedade civil e empresas) e níveis (do local ao global) (KATES; PARRIS; LEISEROWITZ, 2005).

A questão a ser respondida é então o que é para ser sustentado e o que é para ser mudado? Como todo sistema vivo sofre mudanças (pois até mesmo ecossistemas intocados estão em permanente mudança, reciclando seus componentes, adaptando-se a transformações e coevoluindo com elas), o ponto essencial não é eliminar mudanças, mas sim de como gerenciá-las para evitar a destruição de elementos que auxiliam na renovação / recuperação do sistema (GALLOPÍN, 2003).

Gallopín (2003) explica que no conceito de desenvolvimento sustentável a palavra "desenvolvimento" aponta claramente para a ideia de mudança; direcional e progressiva.

Com as atuais transformações tecnológicas, econômicas, ambientais, dentre outras, a tentativa é de garantir que estas mudanças, que afetam a humanidade, sejam mudanças para melhor. Esta tentativa se define na busca de um Desenvolvimento Sustentável.

Ainda segundo Gallópin (2003), o objetivo do Desenvolvimento Sustentável deve ser aumentar a capacidade das dimensões envolvidas (social, ecológica...) em lidar com a mudança, ampliando as opções disponíveis para enfrentar um mundo social e natural em permanente transformação.

Rabinovich e Torres (2004) destacam alguns dos ingredientes essenciais para uma análise da sustentabilidade do desenvolvimento. Esta deve, no mínimo:

a) Ser clara no contexto geográfico e temporal.

b) Levar em conta o efeito do ambiente sobre o bem-estar social e que este deve ser no futuro, pelo menos igual ao de hoje (ignorado na noção de "crescimento").

c) Mostrar uma proeminência no que se refere à sustentação de estoques de recursos naturais e dos serviços ambientais. 
e) Fazer explícita a precisão de satisfazer as necessidades dos pobres do presente junto às necessidades do futuro.

De qualquer forma, é cada vez mais claro que a busca da sustentabilidade e/ou de desenvolvimento sustentável requer a integração de fatores econômicos, sociais, culturais, políticos e ecológicos (GALLOPIN, 2003).

Esta busca tem esquentado a discussão entre governos, comunidade científica, setor privado, organizações não-governamentais e a sociedade de modo geral, no debate sobre os rumos da economia mundial e a forma contemporânea de exploração dos recursos naturais.

Tais discussões fomentam a formulação e debate sobre a mudança de paradigma para a sustentabilidade. Para melhor entendimento deste tema, se mostra interessante recorrer a uma contextualização histórica do mesmo.

\subsection{Origem do termo e sua evolução}

Por muito tempo os conceitos de desenvolvimento e crescimento econômico foram colocados como sinônimos, ligados a parâmetros econômicos, como economia de mercado, PIB, etc. A partir de 1960 as discussões sobre desenvolvimento ganharam novos contornos, gerando o marco das preocupações do homem moderno com o meio ambiente que promoveu a incorporação de questões sociais, ambientais além de econômicas juntamente com o uso racional dos recursos (SANTOS, 2004).

Até este período as poucas nações consideradas desenvolvidas eram aquelas que se tornaram ricas pela industrialização e as consideradas subdesenvolvidas eram as pobres, com processo incipiente ou até inexistente de industrialização (VEIGA, 2005), o que se mostrou algo controverso ao observar os novos contornos do desenvolvimento.

A partir da segunda metade do século XX se iniciou um movimento global, o qual originou inúmeros encontros e conferências, tratados e acordos entre países do mundo inteiro. Ao mesmo tempo a participação das comunidades foi ampliada, principalmente através de ONGs ambientalistas, fortalecendo a iniciativa na formulação de uma nova estratégia de desenvolvimento que contemplasse o meio ambiente como parte integrante e necessária de qualquer progresso humano (DIAS, 2007).

Como consequência, foram surgindo evidências de que o desenvolvimento não se traduzia com o progresso material, sendo uma relação bem mais complexa.

Todavia já eram percebidos esforços partidos de organismos internacionais com o intuito de estabelecer novos parâmetros globais em questões relacionadas com o crescimento econômico, meio ambiente e sociedade. 
Entre os principais marcos e enfatizando a gênesis da preocupação no tema ambiental, em 1962 é publicado o livro Primavera Silenciosa de Rachel Carson, trazendo uma abordagem sobre problemas derivados de pesticidas, em foco o DDT, sendo a repercussão desta obra consideravelmente ampla ao demonstrar a emergência da poluição como um dos grandes problemas ambientais no mundo.

Logo depois, em abril de1968, acontece uma reunião em Roma com integrantes de dez países (cientistas, educadores, indústrias, governo) com o objetivo de discutir os dilemas da época e o futuro do homem, nascendo deste o Clube de Roma. O Clube de Roma tinha em vista promover o entendimento da interdependência dos variados componentes (sociais, políticos, econômicos e ambientais) aos decisores e ao mundo inteiro, através de novas iniciativas e planos de ação (MEADOWS, 1972 apud DIAS, 2007).

Ao mesmo tempo a Organização das Nações Unidas para a Educação, a Ciência e a Cultura (UNESCO), promove em Paris uma Conferência sobre a conservação e o uso racional dos recursos da biosfera, sendo base para o MAB (Man and the Biosphere), programa de cooperação científica internacional sobre as interações entre o homem e seu meio. Devido a este programa, alguns anos depois foi criada uma rede mundial de áreas protegidas denominadas Reservas da Biosfera (DIAS, 2007).

O Brasil, por ser membro das Nações Unidas, participou desta Conferência. A partir daí o país começou a se comprometer mais com a conservação e a proteção do meio ambiente, principalmente levando-o a participar de outras convenções e reuniões internacionais e a fazer parte de acordos e termos de responsabilidade entre países. O reflexo disso foi a criação da Secretaria Especial de Meio Ambiente (SEMA) em1973.

Por este conjunto de eventos o ano de 1968 foi considerado um marco nas discussões sobre o meio ambiente, não apenas pela mobilização de organizações, mas também por mobilizações em massa, principalmente estudantis, contribuindo para o aprofundamento do debate ambiental (DIAS, 2007).

Em 1972 as discussões sobre a preservação do meio ambiente ganharam força, culminando na Conferência das Nações Unidas sobre o Meio Ambiente Humano na cidade de Estocolmo, onde foi criado o Programa das Nações Unidas para o Meio Ambiente (PNUMA), que apresentou novas estruturas de planejamento e estímulos às políticas ambientais .

No mesmo ano o Clube de Roma publicou o relatório "Os Limites do Crescimento" (também conhecido como "Relatório Meadows"), prevendo que as tendências conduziriam a uma carência potencial dos recursos naturais num prazo de 100 anos e que, até o ano de 2010, os alimentos e a produção industrial iriam declinar, culminando em uma diminuição da 
população por faltas de alimento e poluição (DIAS, 2007). Este relatório teve grande repercussão, principalmente no direcionamento do debate da Conferência de Estocolmo.

Estes acontecimentos marcam a percepção da importância em estabelecer a diferença entre crescimento econômico associado à degradação ambiental e uma nova proposta, de um modelo de desenvolvimento que equilibrasse o crescimento econômico com o aspecto social e fosse condizente com a percepção emergente da finitude dos recursos naturais.

Além disso, a repercussão destes eventos e documentos levou a introdução da dimensão ambiental na agenda política internacional, elevando o senso crítico sobre à questão ambiental no mundo.

Foi então que, em 1973, Maurice Strong (secretário geral da Conferência de Estocolmo) lança o conceito de ecodesenvolvimento baseado no uso criterioso dos recursos locais, sem criar dependência externa, com a finalidade de "responder à problemática da harmonização dos objetivos sociais e econômicos do desenvolvimento com uma gestão ecologicamente prudente dos recursos e do meio." (SACHS, 1993).

Porém era definido inicialmente como um estilo de desenvolvimento adaptado às áreas rurais do Terceiro Mundo, sendo parte integrante desta concepção as críticas que relacionavam o conceito como método de desenvolvimento das regiões periféricas (ABRANTES, 2003 ; CAVALCANTI, 1994) . A partir de então, o termo ecodesenvolvimento começou a ser utilizado em vários encontros relacionados ao assunto.

Já na década de 1980, a questão ambiental passou a alcançar o grande público, em grande parte devido a tragédias como Bhopal (1984) e Chernobyl (1986), aumentando a conscientização ambiental na Europa, seguida também nos EUA. Contudo, muito antes destes fatos já havia nascido a visão crítica entre meio ambiente e crescimento econômico.

Deste modo em 1983 é formada a Comissão Mundial sobre o Meio Ambiente e o Desenvolvimento (CMMAD com sigla WCED em inglês), com o objetivo de formular propostas para tratar das questões críticas ambientais e incentivar governos, empresas, organizações voluntárias e indivíduos a uma atuação maior na área ambiental.

Tal comissão (WCED) apresentou em 1987, o relatório de Brundtland "Nosso Futuro Comum", o qual formalizou o conceito de desenvolvimento sustentável como "o atendimento das necessidades do presente sem comprometer a possibilidade das gerações futuras atenderem as suas próprias necessidades".

Neste conceito, foram abordados os princípios da equidade e limitações que a tecnologia e a sociedade implicam no meio ambiente, ou seja, as necessidades humanas são determinadas e sustentadas nos limites ecológicos (WCED, 1987). 
Sendo assim, o relatório criticava o modelo insustentável adotado pelos países desenvolvidos, o qual não poderia ser utilizado pelos países em desenvolvimento, tendo em vista à exaustão dos recursos naturais em ritmo acelerado.

Este foi um ponto de ruptura da abordagem de ecodesenvolvimento, centralizada na manutenção do estado do meio ambiente passando para a abordagem de desenvolvimento sustentável, o qual considera aspectos sociais e econômicos integrados ao aspecto ambiental (SANTOS, 2004) sendo colocado como um novo paradigma.

Já no Brasil, o marco oficial da adesão a intenções com preocupações à conservação do meio ambiente ocorreu com a lei 6938/81, a qual dispõe sobre a Política Nacional do Meio Ambiente (PNMA) (SANTOS, 2004).

Seguindo a linha temporal, em 1992 houve a segunda Conferência Ambiental organizada pela Organização das Nações Unidas (ONU), conhecida como Eco-92 ou Rio 92 por ter sido sediada no Rio de Janeiro, reunindo chefes de Estado com o objetivo de buscar meios que eliminassem as diferenças entre países desenvolvidos e subdesenvolvidos, através de mecanismos que preservassem os recursos naturais.

Esta foi a maior conferência sobre meio ambiente desde Estocolmo, reunindo 175 países (JATOBÁ; CIDADE; VARGAS, 2009). Desta reunião produziram-se vários documentos oficiais, dentre eles três convenções (biodiversidade, desertificação e mudanças climáticas) e a Agenda 21, um documento com 2.500 recomendações para implantar a conservação do planeta dentro do conceito de desenvolvimento sustentável (SANTOS, 2004).

Com o objetivo de analisar a implementação do Programa da Agenda 21 e examinar se as metas estabelecidas pela Conferência do Rio-92 foram alcançadas, foram realizadas outras duas conferências, uma em Nova York e outra em Johanesburgo nos anos de 1997 (Rio + 5) e 2002 (Rio + 10) respectivamente. Os eventos serviram também para que fossem reiterados os compromissos dos Estados com os princípios do Desenvolvimento Sustentável (DIAS, 2007).

Entre as conferências de Nova York e Johanesburgo, em 1999, foi ratificado o Protocolo de Kyoto com o objetivo de apresentar métodos para combate do aquecimento global através de mecanismos de controle das emissões de Gases de Efeito Estufa - GEEs, o qual entrou em vigor oficialmente somente em fevereiro de 2005.

O documento determina que várias nações industrializadas reduzam suas emissões em 5,2\%, em relação aos níveis de 1990, para o período de 2008- 2012 (LUDWIG, 2004). Porém os dois maiores poluidores do mundo, Estados Unidos e China não ratificaram tal protocolo, por defenderem uma política menos rígida de controle de poluição atmosférica. 
Em setembro de 2000 em Nova York houve a Cúpula ou Assembleia do Milênio das Nações Unidas, a qual originou a Declaração do Milênio das Nações Unidas e uma lista de objetivos, principais componentes para a agenda global do Século XXI (IPEA, 2007; PNUD, 2011). Os Objetivos do Milênio das Nações Unidas são:

1. Erradicar a extrema pobreza e a fome;

2. Atingir o ensino básico universal;

3. Promover a igualdade entre os sexos e a autonomia das mulheres;

4. Reduzir a mortalidade infantil;

5. Melhorar a saúde materna;

6. Combater o HIV/AIDS, a malária e outras doenças;

7. Garantir a sustentabilidade ambiental; e

8. Estabelecer uma parceria mundial para o desenvolvimento.

O Quadro 3.1 resume estes principais marcos sobre a formulação do conceito.

\begin{tabular}{|c|c|}
\hline Ano & Acontecimento \\
\hline 1962 & Publicação do Livro Primavera Silenciosa (Silent Spring) \\
\hline 1968 & Criação do Clube de Roma \\
\hline & Conferência da UNESCO sobre a conservação e o uso racional dos recursos da biosfera \\
\hline 1971 & Criação do Programa MAB da UNESCO para a conservação da biodiversidade \\
\hline 1972 & Publicação do Livro Os Limites do crescimento \\
\hline & Conferência das Nações Unidas sobre o Meio Ambiente Humano - Estocolmo \\
\hline 1983 & Formação da Comissão Mundial sobre o Meio Ambiente e o Desenvolvimento (CMMAD) \\
\hline 1987 & Publicação do relatório Brundtland da CMMAD: “ Nosso Futuro Comum” \\
\hline 1992 & Conferência das Nações Unidas sobre o Meio Ambiente e Desenvolvimento - Rio de Janeiro \\
\hline 1997 & Rio $+5-$ Nova York \\
\hline 1999 & Protocolo de Kyoto \\
\hline 2000 & Cúpula ou Assembléia do Milênio das Nações Unidas \\
\hline 2002 & Rio +10 - Cúpula Mundial sobre o Desenvolvimento Sústentável - Johanesburgo \\
\hline $1995-2010^{4}$ & Conferência das Nações Unidas sobre Mudanças Climáticas \\
\hline
\end{tabular}

Quadro 3.1- Principais marcos sobre o conceito de desenvolvimento sustentável

Fonte: Adaptado de Dias (2007).

Diversos eventos, relacionados à questão ambiental, têm ocorrido desde então e vários documentos continuam sendo consolidados por meio destes fóruns e debates internacionais. Dentre estes eventos podem ser elencadas as Conferências sobre Mudanças Climáticas promovidas anualmente desde 1995. É importante destacar que destas Conferências nasceu e é discutido o protocolo de Kyoto apresentado anteriormente.

Sendo assim, mesmo que todos estes esforços não alcancem todos os objetivos esperados, eles servem para discutir sobre as preocupações com intuito de buscar melhores

\footnotetext{
${ }^{4}$ Eventos ocorridos anualmente em diversos locais ao redor do mundo.
} 
soluções para a problemática ambiental. Pode-se observar que tais acontecimentos, encontros e conferências, emanaram uma série de reações críticas, destacando diferentes visões sobre o meio ambiente no debate mundial, provocando uma evolução da visão de sustentabilidade.

\subsection{Evolução da visão de sustentabilidade}

Como visto anteriormente, o termo ecodesenvolvimento é precursor do conceito de sustentabilidade considerado uma proposta mais crítica ao modelo desenvolvimentista do que a proposta mais conciliatória do desenvolvimento sustentável. Pode-se definir o ecodesenvolvimento como um caminho intermediário entre o "ecologismo intransigente" e o “economicismo de visão estreita". (SACHS, 1993)

Nesse sentido, Turner (1987) estabeleceu uma tipologia para as distintas visões sobre o meio ambiente que se enfatizaram no debate mundial, a partir dos anos de 1970. O autor destaca duas visões principais, quais sejam a tecnocentrista e a ecocentrista.

A visão tecnocentrista é considerada uma visão antropocêntrica, na qual o ser humano é como o centro e o senhor da existência e os seres e processos da natureza são unicamente para utilidade humana. O ecocentrismo, por sua vez, nega o antropocentrismo e deposita uma relação igualitária entre os seres e um valor intrínseco à natureza, independente da sua utilidade (TURNER, 1987). Dentro destas visões notam-se algumas divisões, as quais podem ser observadas no Quadro 3.2.

\begin{tabular}{|c|c|}
\hline Visões & Observações \\
\hline Tecnocentrismo extremado & $\begin{array}{l}\text { Livre funcionamento do mercado combinado à inovação } \\
\text { tecnológica, a partir da qual podem ser mitigados os danos } \\
\text { ambientais. }\end{array}$ \\
\hline Tecnocentrismo complacente & $\begin{array}{l}\text { Acredita-se que é possível conciliar crescimento econômico com } \\
\text { equilíbrio ecológico baseado em regras de planejamento e } \\
\text { gerenciamento do uso de recursos naturais. }\end{array}$ \\
\hline Ecocentrismo socialista & $\begin{array}{l}\text { Visão preservacionista que considera certas restrições ao } \\
\text { crescimento econômico em face aos limites físico-sociais. }\end{array}$ \\
\hline Ecocentrismo extremado & $\begin{array}{l}\text { Visão preservacionista radical baseada na "bioética", crítica do } \\
\text { antropocentrismo. Defende a igualdade de todas as espécies e uma } \\
\text { nova ética que substitua os valores antropocêntricos. Dentro desta } \\
\text { categoria variam de matizes suaves até posturas extremistas que } \\
\text { negam o desenvolvimento econômico e intelectual. }\end{array}$ \\
\hline
\end{tabular}

Quadro 3.2- Visões sobre o meio ambiente

Fonte: Adaptado de Turner (1987)

Em paralelo, Jatobá, Cidade e Vargas (2009) explicam a evolução do conceito de sustentabilidade, considerando uma perspectiva política, sendo estas: 
i. Ecologia radical (até década de 1970): sustentabilidade começa a ser modelada a partir das ideias relacionadas com o protecionismo e com o conservacionismo.

ii. Ambientalismo moderado (de 1970 ao final do século XX): a sustentabilidade adquire características mais moderadas quando se apresenta na forma conciliatória da proposta de desenvolvimento sustentável.

iii. Ecologia política (desde o final do século XX até os dias de hoje): quando a sustentabilidade acaba por transformar-se em instrumento de crítica social.

Olhando o quadro histórico dos principais marcos sobre o conceito de sustentabilidade, e relacionando-os as visões de meio ambiente apresentadas por Turner (1987), percebe-se que as visões de sustentabilidade que hoje possuem espaço em debates acadêmicos, na mídia e nas organizações são visões mutáveis.

Nesta análise, percebe-se que o conceito de desenvolvimento sustentável consolidouse somente depois de um período de visão ecológica radical que se opõe ao tecnocentrismo, na qual os aspectos econômicos e sociais eram submissos ao enfoque ecológico, representando as preocupações com a aceleração do processo de industrialização e com o boom econômico do período pós-guerra, somado aos grandes desastres ambientais ocorridos a partir de 1930.

Esta abordagem durou até o início de 1970. Uma evidencia disto é o Relatório Meadows (Os limites do crescimento) que apresentava uma visão catastrófica, sem o otimismo dos cornucopianos (tecnocentristas).

A partir dos anos de 1970 as preocupações ecológicas começam a alcançar as instituições oficiais e a visão ecológica começa a se traduzir em ações governamentais mais efetivas (JATOBÁ; CIDADE; VARGAS 2009). Como exemplos destas preocupações, nos EUA foram promulgadas leis ambientais e criada a Agência Ambiental Norte-Americana (EPA) e no Brasil foi criada a SEMA - Secretaria Especial de Meio Ambiente.

Após a Conferência de 1972, as questões ambientais alcançam um caráter mais político fazendo com que o discurso da sustentabilidade busque contornar resistências à sua aplicação nas políticas de desenvolvimento. Esta é a forma conciliatória trazida pela proposta de desenvolvimento sustentável, sendo, de acordo com as perspectivas apresentadas por Jatobá, Cidade e Vargas (2009), a tendência do ambientalismo moderado e nas abordagens de Turner (1987), uma visão ambiental tecnocentrista complacente.

O ambientalismo moderado de acordo com Pierri (2001) adota uma posição antropocentrista, pois se utiliza do argumento inverso a abordagem egocêntrica, defendendo que é o desenvolvimento que seria comprometido pela degradação ambiental. Para Tayra 
(2006) o tecnocentrismo complacente (ambientalismo moderado) representa a posição econômica e politicamente dominante dentro do ambientalismo global contemporâneo.

Uma terceira perspectiva de sustentabilidade foi selada em 2002 na conferência de Johanesburgo (Rio +10$)$ em face da evidente piora nos indicadores socioambientais dos países pobres. Esta nova perspectiva trouxe componentes como justiça social e governança, concentrando-se no objetivo de redução da pobreza e adquirindo então um caráter socioambiental, chamada de abordagem da ecologia política (JATOBÁ; CIDADE; VARGAS, 2009).

Paralelamente às visões de sustentabilidade Tayra (2006) indica que a visão tecnocêntrica identifica-se com a sustentabilidade fraca enquanto a ecocêntrica entremearia a ideia de sustentabilidade forte.

\subsection{Sustentabilidade forte e sustentabilidade fraca}

Como apresentado por Tayra (2006) as visões tecno e ecocêntricas estão ligadas às ideias de sustentabilidade fraca e forte. Estas duas correntes relacionadas à sustentabilidade, segundo Romeiro (2003), são representadas pelas chamadas economia ambiental e economia ecológica.

Adicionalmente Romeiro (2003) identifica que a economia ambiental considera que os recursos naturais (fontes de insumo e/ou de capacidade de assimilação de impactos), em longo prazo, não representam um limite irrestrito à expansão econômica. $\mathrm{O}$ autor observa que inicialmente esses recursos sequer eram apreciados em análises econômicas.

Como exemplo, Binswanger (1999) traz que na teoria econômica consideram-se como fatores únicos de produção o produto nacional da sociedade (Y) como resultado da combinação de trabalho $(\mathrm{L})$ e capital $(\mathrm{K})$, como descrita pela relação: $Y=f(L, K)$.

Isto significa que os serviços naturais, ou seja, a natureza, que é essencial para toda a produção material é totalmente negligenciada. Daí a falsa impressão que durante o processo nada é destruído, esquecendo que a matéria incorporada aos bens de consumo retorna como lixo e emissões à natureza.

Sendo assim, Binswanger (1999) afirma que seguindo esta razão nada resulta de nada sendo que, nada é devolvido ao nada, isto é, as entradas (inputs), saídas (outputs) e suas relações com o estado do meio são desconsideradas, o que não se observa na realidade sistêmica na qual se passa a vida e mesmo a própria economia.

Romeiro (2003) afirma que esta visão é pertencente à abordagem econômica neoclássica e que, com o tempo, os recursos naturais passaram a ser incluídos nas 
representações de função de produção, porém manteve-se dentro do sistema econômico a suposição que a disponibilidade de recursos naturais é apenas uma restrição relativa à extensão econômica, superável indefinidamente pelo progresso científico e tecnológico. Proveniente desta visão passou a existir a concepção conhecida como sustentabilidade fraca.

Já na economia ecológica, a visão é que o sistema econômico é um subsistema de um todo maior, atribuindo uma restrição absoluta à sua expansão devido à discordância em relação à infinitude dos recursos naturais e da capacidade de superação dos limites ambientais observados. Esta visão de acordo com Romeiro (2003) é representada através do conceito de sustentabilidade forte.

Tayra (2006), por sua vez, compreende que a sustentabilidade fraca pode ser alcançada mediante práticas econômicas de substituição de capital natural e que por meio da tecnologia e bens manufaturados podem-se resolver quaisquer problemas ambientais. Por outro lado, o autor aponta que a sustentabilidade forte não admitiria a possibilidade de substituição do capital natural pelo manufaturado e propõe uma mudança radical do modelo econômico.

Dietz e Neumayer (2007 apud SICHE, 2007) afirmam que na validação de um paradigma voltado a sustentabilidade fraca, é preciso que um dos seguintes itens seja verdadeiro: i. os recursos naturais são superabundantes; ii. a elasticidade da substituição entre capital natural e humano é maior ou igual à unidade (equilíbrio no limite da razão produçãorecurso); e iii. o progresso tecnológico pode aumentar a produtividade do estoque de capital natural mais rápido do que ele está sendo utilizado.

Para Redclift (2007, p. 68) o “desenvolvimento sustentável é descrito como 'forte', ao invés de 'fraco', quando é mais difícil substituir capital-humano pela natureza", ou seja, a sustentabilidade é forte quando existe uma resistência em realizar substituições para expansão econômica, tendo em vista que o capital e o trabalho não podem prover o mesmo desenvolvimento que os serviços da natureza.

Considerando todas estas diferentes abordagens, a sustentabilidade é entendida como um objetivo maior perseguido, porém deve-se tornar comum ao almejar uma harmonia entre desenvolvimento ecologicamente equilibrado, socialmente igual e economicamente viável, independente das diferentes propostas para alcançá-lo.

Esta questão não se relaciona apenas à emersão e transição do conceito de sustentabilidade ao longo do tempo, mas também sua importância e às definições relacionadas aos diferentes valores e olhares sobre a questão, delimitando e orientando opiniões. Montibeller-Filho (2000, p. 44) explica que “o desenvolvimento sustentável é um 
conceito amplo e que por esta característica permite apropriações diferenciadas e ideologizadas por segmentos sociais de interesse."

Ao mesmo tempo, Kates, Parris e Leiserowitz (2005) comentam sobre a vantagem da heterogeneidade do conceito, o que representa flexibilidade dinâmica e abertura para adaptação e utilização em diversas situações contextuais e temporais. Sendo assim, é possível adequar o uso deste conceito às peculiaridades das múltiplas esferas (governamental, sociedade civil e empresas) e níveis (do local ao global).

De qualquer forma a abordagem tradicional de sustentabilidade trazida pelo relatório Brundlant tem sua importância no aspecto ideológico da questão, sendo base para o entendimento multidimensional do contexto, o que constitui a ótica que caracteriza o "verdadeiro desenvolvimento" (expressão de ELMAR ALTVATER, 1995 apud MONTEBELLER-FILHO, 2000).

Esta abordagem tradicional de sustentabilidade que segue os preceitos do Relatório Brundtland é entendida como um processo de mudança, o qual considera diferentes dimensões: ecológica, social, econômica e institucional (TAYRA, 2002). Estas dimensões, tanto como o conceito, também podem ser adaptadas devido às peculiaridades já citadas e, por tanto, elas também são mutáveis, podendo haver acréscimo de dimensões, ou podendo utilizar somente aquelas presentes na base da abordagem tradicional.

\begin{tabular}{|l|l|}
\hline \multicolumn{1}{|c|}{ DIMENSÕES } & \multicolumn{1}{c|}{ CARACTERÍSTICAS } \\
\hline Social & $\begin{array}{l}\text { Melhoria na qualidade de vida baseando-se na justiça da distribuição de renda, } \\
\text { bens e serviços e na diminuição de diferenças nos campos da educação, saúde, } \\
\text { habitação, etc., ou seja, diminuição das diferenças sociais e das taxas de pobreza. }\end{array}$ \\
\hline Econômica & $\begin{array}{l}\text { Desenvolvimento intersetorial balanceado, com capacidade de modernização } \\
\text { contínua dos instrumentos de produção, com inserção imperante na economia } \\
\text { internacional e com certa autonomia na pesquisa científica/tecnológica. }\end{array}$ \\
\hline Ecológica & $\begin{array}{l}\text { Capacidade de uma população ocupar uma determinada área, explorando seus } \\
\text { recursos naturais sem prejudicar, ao longo do tempo, a integridade ecológica do } \\
\text { meio ambiente no qual está incluso. }\end{array}$ \\
\hline Cultural & $\begin{array}{l}\text { Busca a realização de mudanças em harmonia com a continuidade cultural } \\
\text { vigente. }\end{array}$ \\
\hline Ambiental & Permite que ecossistemas naturais realizem autodepuração. \\
\hline Territorial & $\begin{array}{l}\text { Visa a eliminação de desigualdades interregionais, a destinação igualitária de } \\
\text { investimentos públicos e a visão do eco-desenvolvimento na conservação da } \\
\text { biodiversidade. }\end{array}$ \\
\hline Política nacional & $\begin{array}{l}\text { Está relacionada a um nível razoável de coesão social, democracia e à capacidade } \\
\text { do Estado de implementar o projeto nacional. }\end{array}$ \\
\hline $\begin{array}{l}\text { Política } \\
\text { internacional }\end{array}$ & $\begin{array}{l}\text { Tem relação direta com o controle do sistema financeiro internacional, garantia } \\
\text { da paz, gestão do patrimônio global como herança da humanidade, verdadeira } \\
\text { cooperação científica e diminuição das disparidades sociais entre os hemisférios } \\
\text { norte-sul. }\end{array}$ \\
\hline
\end{tabular}

Quadro 3.3. As diferentes dimensões da sustentabilidade

Fonte: Baseado em Sachs (1990). 
Na opinião de Sachs (2002), a sustentabilidade tem como diferentes bases as dimensões: social, econômica, ecológica, cultural, ambiental, territorial, a de política nacional e a de política internacional.

O reconhecimento de interdependência entre as diferentes dimensões, de acordo com Gomes (2004), é necessário para que seja alcançado um desempenho alinhado ao conceito de desenvolvimento sustentável.

De qualquer forma, não basta definir o que é sustentabilidade e quais devem ser suas dimensões sem decidir o caminho a ser seguido para atingir tal sustentabilidade. Não obstante, a avaliação sobre o desempenho da estratégia decidida deve ocorrer para que haja críticas que auxiliem em encontrar novas propostas, possibilitando êxito na busca do desenvolvimento sustentável.

\subsection{Aspectos relacionados à busca pelo desenvolvimento sustentável}

O desenvolvimento sustentável está relacionado a uma série de visões e dimensões, se figurando como um conceito intrinsecamente complexo. Dadas as suas relações sistêmicas, atingir o desenvolvimento sustentável implica na necessidade de considerar diversos aspectos.

Segundo Fernandez (2005), para se atingir a sustentabilidade é necessário:

i. Conservar o meio ambiente;

ii. Controlar o crescimento populacional;

iii. Diminuir o consumismo;

iv. Mudar a economia (coletivar os lucros ou individualizar os prejuízos);

v. Mudança cultural (de quem tem mais é o melhor).

Neste contexto surgem os "Princípios de Bellagio", os quais representam a síntese consensual sobre os principais aspectos relacionados à avaliação do desenvolvimento sustentável.

Tais princípios foram concebidos em 1996 por ocasião da reunião de especialistas e pesquisadores que ocorreu no Centro de Conferências de Bellagio na Itália, apoiado pela Fundação Rockfeller (HARDI e ZDAN,1997).

Os Princípios de Bellagio, segundo Hardi e Zdan (1997) servem como guia para implementação e/ou avaliação de um processo que almeje a sustentabilidade, desde a escolha e o projeto de indicadores, a sua interpretação, até a comunicação de resultados, sendo assim, a avaliação do progresso rumo à sustentabilidade pode seguir tais princípios. Os mesmos autores afirmam que estes princípios estão interrelacionados e devem ser aplicados conjuntamente, orientando para a melhoria dos processos de avaliação na sua aplicação. 
São dez os princípios formulados (Quadro 3.4) com esta intenção, utilizados na avaliação de iniciativas de desenvolvimento em todos os níveis, desde o comunitário até as experiências internacionais (VAN BELLEN, 2005).

\begin{tabular}{|c|c|}
\hline Princípios & A avaliação do progresso rumo à sustentabilidade deve \\
\hline $\begin{array}{l}\text { 1.1- GUIA DE } \\
\text { VISÃO E METAS }\end{array}$ & $\begin{array}{l}\text { - Ser guiada por uma visão clara do que seja desenvolvimento sustentável e } \\
\text { das metas que definem esta visão. }\end{array}$ \\
\hline $\begin{array}{l}\text { 2- PERSPECTIVA } \\
\text { HOLÍSTICA }\end{array}$ & $\begin{array}{l}\text { - Incluir uma revisão do sistema todo e de suas partes. } \\
\text { - Considerar o bem-estar dos subsistemas ecológico, social e econômico, seu } \\
\text { estado atual, bem como sua direção e sua taxa de mudança, de seus } \\
\text { componentes, e a interação entre as suas partes. } \\
\text { - Considerar as conseqüências positivas e negativas da atividade humana de } \\
\text { modo a refletir os custos e benefícios para os sistemas ecológico e humano em } \\
\text { termos monetários e não monetários. }\end{array}$ \\
\hline $\begin{array}{l}\text { 3- ELEMENTOS } \\
\text { ESSENCIAIS }\end{array}$ & $\begin{array}{l}\text { - Considerar a eqüidade e a disparidade dentro da população atual e entre as } \\
\text { gerações presentes e futuras, lidando com a utilização de recursos, } \\
\text { superconsumo e pobreza, direitos humanos e acessos a serviços. } \\
\text { - Considerar as condições ecológicas das quais a vida depende. } \\
\text { - Considerar o desenvolvimento econômico e outros aspectos que não são } \\
\text { oferecidos pelo mercado e contribuem para o bem-estar social e humano. }\end{array}$ \\
\hline $\begin{array}{l}\text { 4- ESCOPO } \\
\text { ADEQUADO }\end{array}$ & $\begin{array}{l}\text { - Adotar um horizonte de tempo suficientemente longo para abranger as } \\
\text { escalas de tempo humano e dos ecossistemas, atendendo às necessidades das } \\
\text { futuras gerações, bem como da geração presente em termos de processo de } \\
\text { tomada de decisão em curto prazo. } \\
\text { - Definir o espaço de estudo para abranger não apenas impactos locais, mas } \\
\text { também impactos de longa distância sobre pessoas e ecossistemas. } \\
\text { - Construir um histórico das condições presentes e passadas para antecipar } \\
\text { futuras condições. }\end{array}$ \\
\hline $\begin{array}{l}\text { 5- FOCO } \\
\text { PRÁTICO }\end{array}$ & $\begin{array}{l}\text { Ser baseada em: } \\
\text { - Um sistema organizado que relacione as visões e metas dos indicadores e os } \\
\text { critérios de avaliação. } \\
\text { - Um número limitado de questões-chave para análise. } \\
\text { - Um número limitado de indicadores ou combinação de indicadores para } \\
\text { fornecer um sinal claro do progresso. } \\
\text { - Uma padronização das medidas quando possível para permitir comparações. } \\
\text { - Uma comparação dos valores dos indicadores com as metas, valores de } \\
\text { referência, padrão mínimo e tendências. }\end{array}$ \\
\hline $\begin{array}{l}\text { 6-ABERTURA / } \\
\text { TRANSPARÊNCIA } \\
(\text { OPENNESS }) \\
\end{array}$ & $\begin{array}{l}\text { - Construir os dados e indicadores de modo que sejam acessíveis ao público. } \\
\text { - Tornar explícitos todos os julgamentos, suposições e incertezas nos dados e } \\
\text { nas interpretações. }\end{array}$ \\
\hline $\begin{array}{l}\text { 7- } \\
\text { COMUNICAÇÃO } \\
\text { EFETIVA }\end{array}$ & $\begin{array}{l}\text { - Projetada para atender às necessidades do público e do grupo de usuários. } \\
\text { - Ser feita de forma que os indicadores e as ferramentas estimulem e engajem } \\
\text { os tomadores de decisão. } \\
\text { - Procurar a simplicidade na estrutura do sistema e utilizar linguagem clara e } \\
\text { simples. }\end{array}$ \\
\hline
\end{tabular}

(Continua...) 


\begin{tabular}{|c|c|}
\hline $\begin{array}{l}\text { 8- AMPLA } \\
\text { PARTICIPAÇÃO }\end{array}$ & $\begin{array}{l}\text { - Obter ampla representação do público: profissionais, técnicos e } \\
\text { comunitários, incluindo participação de jovens, mulheres e indígenas para } \\
\text { garantir o reconhecimento dos valores, que são diversos e dinâmicos. } \\
\text { - Garantir a participação dos tomadores de decisão para assegurar uma forte } \\
\text { ligação na adoção de políticas e nos resultados da ação. }\end{array}$ \\
\hline $\begin{array}{l}\text { 9- AVALIAÇÃO } \\
\text { CONSTANTE }\end{array}$ & $\begin{array}{l}\text { - Desenvolver a capacidade de repetidas medidas para determinar tendências. } \\
\text { - Ser interativa, adaptativa e responsiva às mudanças, porque os sistemas são } \\
\text { complexos e se alteram frequentemente. } \\
\text { - Ajustar as metas, sistemas e indicadores com os insights decorrentes do } \\
\text { processo. } \\
\text { - Promover o desenvolvimento do aprendizado coletivo e o feedback } \\
\text { necessário para a tomada de decisão. }\end{array}$ \\
\hline $\begin{array}{l}10- \\
\text { CAPACIDADE } \\
\text { INSTITUCIONAL }\end{array}$ & $\begin{array}{l}\text { Ser continuada e assegurada por: } \\
\text { - Delegação clara de responsabilidade e provimento de suporte constante no } \\
\text { processo de tomada de decisão. } \\
\text { - Provimento de capacidade institucional para a coleta de dados, sua } \\
\text { manutenção e documentação. } \\
\text { - Apoio ao desenvolvimento da capacitação local de avaliação. }\end{array}$ \\
\hline
\end{tabular}

Quadro 3.4- Princípios de Bellagio

Fonte: Adaptado de Hardi e Zdan (1997)

Estes princípios podem ser vistos como conjuntos de metas, ações, que facilitam o alcance do progresso rumo à sustentabilidade e/ou que são necessárias para a mensuração da mesma.

Ainda no contexto dos aspectos a serem considerados no processo de avaliação ou mensuração da sustentabilidade, Van Bellen (2005) ilustra que o mesmo deve estar focado nos seguintes pontos:

i. Nas atividades que criam problemas nos ecossistemas locais e no ambiente global, na economia local e nacional, e nas comunidades e indivíduos;

ii. Nas mudanças resultantes no ecossistema, na economia e na sociedade e indivíduos em curto e em longo prazo, reversíveis e não reversíveis;

iii. Nas respostas do sistema político, sua extensão e seu impacto.

Como observado neste contexto teórico sobre a sustentabilidade, suas interfaces e sobre os aspectos a serem considerados em sua avaliação, existem valores divergentes para os diferentes atores em relação ao 'o que' precisa ser sustentável.

Segundo Redclift (2007) e Veiga (2005), em geral, são os níveis de produção e consumo presentes e futuros que precisam ser sustentáveis.

Para os autores o aumento da população em nível global ocasionará o aumento das demandas no meio ambiente, fato que deveria ser incorporado na definição do conceito de desenvolvimento sustentável. 
Redclift (2007) também identifica que, ao mesmo tempo em que haveria um aumento de renda individual para população global, as práticas de consumo individual também mudariam, dando a escolha para populações, como a do Brasil, de ter um estilo de vida como uma população norte-industrializada.

De acordo com Veiga (2005) o que desvia esta situação atualmente é a incapacidade financeira destas pessoas em serem consumidores efetivos, porém existe certa preocupação se países como a China e a Índia continuarem apresentando elevados índices de crescimento econômico por um longo período. Por estes motivos que o desenvolvimento sustentável é considerado fator indutor do ponto de equilíbrio socioeconômico e ambiental e implica em mudanças nos processos de produção e consumo.

Estes conceitos e pretensões de mudança na sociedade buscam evitar que a crise ambiental continue aumentando em todo o mundo e que sistemicamente não aconteça o mesmo com as outras dimensões integradas ao processo de sustentabilidade.

Sheng (1999) afirma que as causas que acionam as atividades insustentáveis podem ser conferidas às instituições sociais, aos sistemas de informação e aos valores adotados pela sociedade. Isto porque estes atores, supostamente, colocam em prática valores que são onerosos à sociedade.

Os valores sociais determinam o certo do errado, o que é ou não importante do ponto de vista de uma sociedade e os econômicos estão relacionados a estes valores sociais.

Através de suas observações, Sheng (1999) expressa que o produto de um sistema de informação amplo de uma sociedade são os indicadores de sustentabilidade. Estes devem expressar os valores de aspectos sociais, ambientais e econômicos colocados pela sociedade nos níveis local, nacional e global e devem ser desenvolvidos e utilizados pelas instituições sociais para fazer cumprir os representativos valores sociais.

Com isto, os indicadores podem conduzir as atividades humanas na direção de uma sociedade sustentável. Sendo assim, os sistemas de informação podem refletir os valores de uma sociedade, como também podem influenciar estes valores.

Para que sejam capazes de refletir os valores de uma sociedade, bem como influenciar positivamente estes valores rumo ao desenvolvimento sustentável, tais sistemas precisam ser credíveis e adequados para apoiar decisões, considerando os preceitos envolvidos pelo conceito de sustentabilidade.

Observa-se, por tal contexto que, para implantar uma estratégia voltada para a sustentabilidade, há um longo caminho no ponto de vista pragmático, já que deve-se transformar e ajustar as práticas de planejamento e gestão do global ao local. 
Não obstante, é necessário avançar na compreensão dos processos humanos e naturais, bem como suas relações com os problemas ambientais, econômicos e sociais para que seja possível colocar em prática o conceito de desenvolvimento sustentável.

Como observado ao longo do capítulo a evolução do conceito e suas diversas reflexões tiveram como principais produtos a sua evolução em termos de conscientização ambiental, emprego em ações e políticas públicas por meio de debates e conferências, bem como nas tentativas de conciliação de objetivos econômicos, demandas sociais e qualidade ambiental.

Para que ocorram expressivos incrementos nestas discussões, bem como ocorra a promoção de ações efetivas, embasando futuras discussões e tomadas de decisão mais concretas na busca pelo desenvolvimento sustentável, é necessário que as informações disponíveis cumpram seu importante papel de promover o conhecimento e a sensibilização dos diversos atores na busca pela sustentabilidade.

Portanto o capítulo a seguir traz uma discussão sobre indicadores, mais especificamente indicadores ambientais, e sua qualidade em apoiar o debate sobre a sustentabilidade. 


\section{INDICADORES AMBIENTAIS NA INFORMAÇÃO E TOMADA DE DECISÃO}

Para apoiar políticas voltadas para a sustentabilidade é necessário suporte por informações que sejam relacionadas a diferentes processos, tais como o econômico, social e ambiental, sendo que tais informações devem ser monitoradas de maneira transparente e comunicadas por uma vasta gama de meios de comunicação (MCGLADE, 2007).

A informação é um fator crítico para o sucesso do gerenciamento das constantes mudanças e inovações que ocorrem no desenvolvimento, seja esta informação integrada ou mesmo por dimensões (social, ambiental, econômico, outros).

A comunicação da informação é a principal função dos indicadores ambientais (EEA, 2003). Eles fornecem conhecimento sobre questões e/ou fenômenos considerados importantes para os seus diversos usuários, subsidia os processos de planejamento e gestão ambiental favorecendo o controle e monitoramento do meio ambiente, bem como o aumento da participação da sociedade na gestão pública (SANTOS, 2004).

Deste modo, um indicador ambiental deve possuir disponibilidade em qualidade e quantidade, não se resumindo apenas a um exercício teórico de aproximação da realidade. Isto porque a informação relevante, atual e adequada é a chave para o planejamento e tomada de decisão (LIMA, 2008).

Neste sentido, o presente capítulo fará entender o que são indicadores ambientais, como surgiram, a importância de sua qualidade e disponibilidade e seu papel como informação e suporte à tomada de decisão.

\subsection{O que define um indicador?}

As atuais definições dos indicadores e do uso da terminologia nesta área são particularmente confusas (BAKKES et al., 1994). Esta elevada quantidade de termologias e entendimentos pode dar margem à existência de equívocos na definição e utilização de indicadores que muitas vezes são utilizados como sinônimos de "dados, informação, parâmetro e/ou variáveis". Por isso, é interessante recorrer à etimologia para melhor esclarecimento sobre estes termos e da definição empregada na pesquisa.

Quando se toma do termo "dado" faz-se referência a uma medida, quantidade, ou observação de uma propriedade (parâmetro), que pode ser apresentado de diversas formas, tais como números, descrições, caracteres ou mesmo símbolos (SANTOS, 2004).

Segundo Winograd e Farrow (2009) os dados são a base para indicadores, índices, informações e por si só não podem ser usados para interpretar mudanças ou condições. 
Contudo, como destacado por Magalhães Jr (2007) a qualidade do dado está baseada na sua qualidade informacional, ou seja, na sua capacidade de transmitir conhecimento, por meio de sua interpretação. Assim, um dado torna-se um indicador quando sua compreensão ultrapassa o número, a mensuração, no sentido de adquirir significado através da informação interpretada (veja o Quadro 4.1).

Não obstante é importante lembrar que há diferentes visões, interpretações, usos e destinações, quando o dado ou informação é analisado (OECD, 1993). Ex: um valor sobre um parâmetro ligado à água pode ter diferentes significados quando analisado em diferentes regiões sob a forma de um indicador de qualidade de água.

Um mesmo indicador pode também ser visto de diferentes maneiras. Neste sentido um mesmo indicador pode representar diferentes dimensões, dependendo do sistema em que ele esta sendo analisado (BRIASSOULIS, 2001). Por ex: PIB; taxa de desmatamento; tratamento de água... - podem ser vistos como indicadores ambientais (indicadores de pressão no sistema ambiental) ou indicadores econômicos (indicadores de estado no sistema econômico).

Parâmetro Dado

Quadro 4.1- Caracterização de um parâmetro como indicador.

Fonte: Baseado em Santos (2004).

Sendo assim, não se considera como indicador a simples mensuração de um parâmetro (valor), mas sim a informação que provém do significado desta mensuração, possibilitando, portanto avaliar a situação e as tendências do ambiente (no caso do indicador ambiental).

Em outra visão, Gallopín (1997) traz que o Indicador é uma variável, a qual é uma representação operacional de um atributo (característica, propriedade do sistema), sendo que esta variável transmite informação da condição e/ou tendência do atributo. Ainda segundo o autor, a variável indica o atributo, não sendo o atributo em si, mas a imagem do atributo (mensuração específica ou processo de observação). 
Desta forma, ao comparar a visão de Gallopín (1997) com a visão tramada anteriormente, observa-se que são formas distintas de explicar um indicador, sendo que a abordagem apresentada por Gallopín, uma abordagem de concepção, enquanto outras definições tentam apresentar uma estrutura de formação de um indicador.

Ainda assim, a característica essencial que permeia um indicador é a sua capacidade de transmitir informação sobre as condições ou tendências de uma característica do sistema , sendo esta definição concordada por todas estas vertentes.

Não obstante, observa-se na teoria questionamentos sobre a existência de diferenças entre indicador e índice.

Khanna, (2000) coloca que um índice é composto de indicadores (suas variáveis) e resulta em um valor agregado final baseado em todo um procedimento de cálculo. De uma forma mais simples, a autora expressa que um índice é um indicador de alta categoria, salientando adicionalmente que um índice pode compor outro índice.

Porém, o termo indicador se refere a um parâmetro selecionado, que pode, nas visões de Siche et al. (2007), ser considerado isoladamente ou em combinação com outros indicadores (indicador agregado) com intuito de refletir as condições do sistema em análise.

Desta forma, um Indicador Agregado pode ser definido como a reunião de parâmetros (ou indicadores) não envolvendo ponderações ou outras técnicas analíticas adicionais, sendo que um indicador simples seria definido como aquele que representa um único parâmetro (SANTOS, 2004).

Apesar da simples ideia de definição de índice ser baseada em agregação de indicadores, Gallopín (1997) refuta tal definição e afirma que a distinção entre índices e indicadores baseia-se na complexidade da função pelos quais os mesmos são obtidos, onde um índice advém de numa função complexa de duas ou mais variáveis individuais.

Gomes, Marcelino e Espada (2000) consideram indicadores como um pré-tratamento aos dados originais enquanto que os índices correspondem a um nível superior de agregação.

Como expresso por Van Bellen (2005), os índices se mostram necessários ao informar sobre os problemas complexos do desenvolvimento sustentável, pois os tomadores de decisão podem se utilizar destes índices no processo decisório por serem, desconsiderando as exceções, facilmente entendíveis.

Contudo, alguns autores indicam que ainda que o alto nível de agregação intensifique a percepção dos problemas, tal agregação faz com que sejam perdidas ou escondidas informações em cada estágio de agregação; informações estas potencialmente valiosas na 
orientação de ações para a sustentabilidade ou solução de problemas (MEADOWS, 1998; BOSSEL, 1999; GALLOPÍN, 1997; SANTOS, 2004; REED, FRASER e DOUGILL, 2006).

Deste modo, as principais vantagens do índice são a facilidade de comunicação com o público que não se interessa por detalhes e prefere quadros resumidos dos principais fatos, além do fato de representar diversas variáveis em um único número. No entanto, sua principal desvantagem consiste na perda de informação das variáveis individuais, não substituindo uma avaliação detalhada de um construto.

Hammond et al. (1995) apresentam a estrutura de agregação de dados sob a forma de pirâmide de informação. Para melhor compreensão da relação entre a pirâmide de informação, correspondente ao nível de agregação dos dados, com o nível de entendimento sobre esta agregação é possível recorrer à Figura 4.1.

Nesta figura são demonstradas a pirâmide de Hammond et al. (1995) em paralelo à pirâmide apresentada por Emmert et al. (1996 apud SHIELDS; SOLAR; MARTIN, 2002).

Como é possível observar, o topo da pirâmide de informação corresponde ao grau máximo de agregação de dados, enquanto a base representa os dados primários desagregados, e a consideração de quais etapas são necessárias vai depender das particularidades de cada avaliação (SHIELDS; SOLAR; MARTIN, 2002).

Uma análise interessante é feita por Santos (2004) ao colocar que à medida que se eleva o nível na pirâmide também se eleva os níveis de custo. Assim, quanto mais se trabalha em níveis menores, mais o trabalho é viável economicamente.

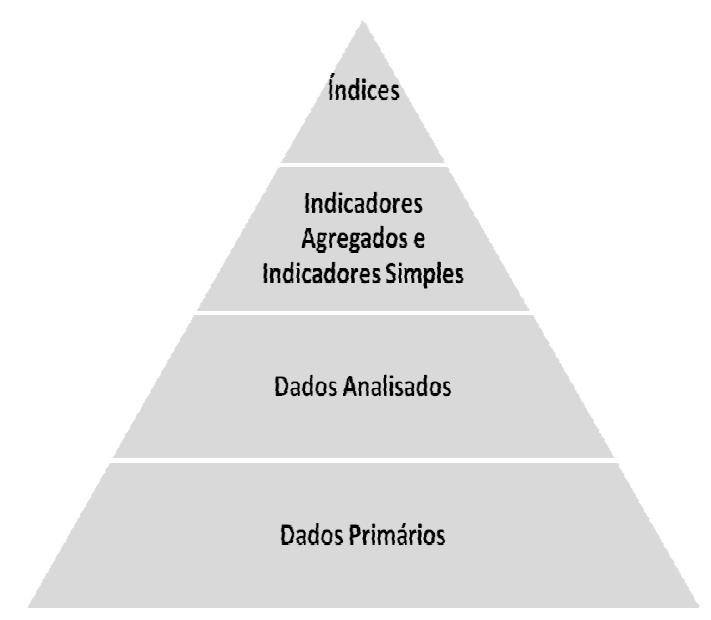

(a)

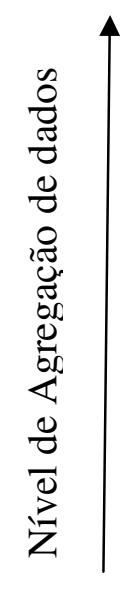

(b)

(a) Pirâmide de informação representando o nível de agregação; e

(b) a relação entre a agregação e o usuário.

Figura 4.1- Pirâmide de informação e sua relação com o usuário

Fonte: Baseado em Hammond et al. (1995) e Emmert et al. (1996 apud SHIELDS; SOLAR; MARTIN, 2002). 
Ao relacionar a pirâmide de informação (representando o nível de agregação) e a pirâmide de usuário, observa-se que os índices e indicadores (mais simples como, por exemplo, os qualitativos) são utilizados por tomadores de decisão e o público em geral devido a sua objetividade e simplicidade, desconsiderando exceções. Já no caso de dados unicamente com tratamentos estatísticos, ou primários, são compreensíveis e necessários por aqueles que precisam de uma informação mais técnico-científica.

Sendo assim, a eficiência na compreensibilidade e utilidade do indicador vai depender da sua relação com seu usuário. Observa-se pelo histórico dos indicadores (apresentado na sessão seguinte) que tais usuários, bem como os próprios indicadores sofreram mudanças ao longo de seu desenvolvimento e utilização.

Contudo, baseando nas visões observadas é possível evidenciar que o termo indicador está voltado à sua função informacional, e deste modo um índice é considerado um indicador no que diz respeito a esta função.

Suas diferenças se encontram somente no formato estrutural, sendo o índice um agregado de informações com um resultado único baseado em um procedimento de cálculo mais complexo, enquanto um indicador possui uma estrutura mais simples, envolvendo o resultado para um único parâmetro ou mesmo possibilitando uma união com outros indicadores (agregados).

\subsection{O surgimento dos indicadores ambientais}

Como estabelecem Turnhout, Hisschemoller e Eijsackers (2007), ainda que em 1902 Kolkwitz e Marsson já se utilizassem de indicadores ambientais (espécies indicadoras) para descrever ecossistemas aquáticos, os indicadores começaram a obter um caráter mais acadêmico e político somente na década de 1980.

Segundo Cappelli (2007) a ideia inicial para o desenvolvimento e utilização de conjunto de indicadores ambientais ocorreu no Canadá e em alguns países da Europa.

Adicionalmente Quiroga (2001) explica que são três as gerações de indicadores. Os chamados indicadores de primeira geração surgiram na década de 1980, sendo que as relações socioeconômicas que envolvem o desenvolvimento não eram incorporadas por tais indicadores e estes não buscavam inter-relações entre os componentes de um sistema. Podem ser citados como exemplos destes indicadores o de emissões de $\mathrm{CO}_{2}$ e de erosão do solo.

A formulação e operação de indicadores de segunda geração iniciaram-se com a Conferência das Nações Unidas em 1992, com a difusão do conceito de "desenvolvimento sustentável". Isto de alguma forma em resposta aos preceitos da Agenda 21 como uma 
maneira de monitorar o progresso tendo em vista o desenvolvimento sustentável.

Como apresentado no capítulo anterior, a grande motivação para trabalhos de planejamento e desenvolvimento sustentável se originou deste encontro, integrando as dimensões econômicas, social, ambiental e institucional.

Por isto observavam-se demandas na elaboração de indicadores mais completos e complexos; o que resultou nos chamados indicadores de segunda geração. Estes indicadores passaram a ser multidimensionais, ou seja, compostos por quatro dimensões fundamentais do desenvolvimento: a econômica, a social, a institucional e a ambiental, mas ainda não estabeleciam ligações entre si.

Neste momento a Organização das Nações Unidas constituiu a CDS (Comissão de Desenvolvimento Sustentável) para monitorar os avanços em direção ao desenvolvimento sustentável (CAPPELLI, 2007).

A CDS teve como função primordial liderar os esforços para motivar a criação e o planejamento do uso de indicadores ambientais e de desenvolvimento sustentável nos países signatários da Agenda 21.

Desta forma, a segunda geração de indicadores (iniciados na década de 1990) corresponde a um foco multidimensional do desenvolvimento sustentável, sendo conhecidos como indicadores de sustentabilidade.

$\mathrm{Na}$ terceira geração, os esforços não se concentraram mais na criação de listas de indicadores multidimensionais, e sim na criação de indicadores vinculantes, sinérgicos, que apresentassem correlações claras com os demais, indicando as diversas manifestações de um mesmo sistema.

Com a ascensão da visão sistêmica nas discussões de sustentabilidade é evidenciada a necessidade de indicadores de terceira geração. Contudo, o desenvolvimento deste tipo de indicador se encontra ainda em uma fase incipiente, estando mais consolidados em termos de discussão e emprego os indicadores de primeira e segunda geração.

Ainda sobre o desenvolvimento de indicadores de segunda e terceira geração, Quiroga (2001) coloca que os países que alcançaram notoriedade pela qualidade de suas propostas são o Canadá e a Nova Zelândia. Já na América Latina quem vem liderando estas iniciativas são: México, Chile, Costa Rica e Brasil.

Como apresentado por Quiroga (2001) é possível observar que os indicadores ambientais caracterizam-se como os indicadores de primeira geração, pois correspondem aos primeiros indicadores idealizados por volta dos anos 80 e que têm sido desenvolvidos até hoje. Tais indicadores são parte integrante da sistemática sustentável, representando desde um 
fenômeno ambiental complexo (sistema florestal, aquático), até uma dimensão reduzida (ambiente contaminado em um setor produtivo).

Com a crescente importância do tema, observam-se uma intensa produção de trabalhos sobre indicadores atualmente. No caso do Banco Mundial, é apresentado anualmente um documento sobre Indicadores de Desenvolvimento Mundial que traz centenas de dados e levantamentos estatísticos sobre todos os tipos de indicadores de mais de 180 países, dentre os quais se encontra o Brasil.

Este trabalho é fruto das contribuições das diversas organizações nacionais e internacionais, governamentais e não governamentais distribuídas entre os países participantes. São estas: FAO (Organização das Nações Unidas para Agricultura e Alimentação), IMF (Fundo Monetário Internacional), UNESCO (Organização das Nações Unidas para a Educação, Ciência e Cultura), UNEP (Programa Ambiental das Nações Unidas), dentre outras (THE WORLD BANK, 2006).

Quase 20 anos depois da conferência das Nações Unidas, muito foi aprendido sobre o uso potencial de indicadores em avanço ao desenvolvimento sustentável. Assim, uma vez que os indicadores ambientais são parte integrante da sistemática sustentável, pode-se considerar que os mesmos visam compor parte do conjunto de funções dos indicadores de sustentabilidade, as quais, segundo Malheiros, Phillip Jr. e Aguiar (2005) são as que seguem:

- Prover maior entendimento nas complexas conexões entre os elementos da sustentabilidade;

- Comunicar assuntos relevantes sobre sustentabilidade;

- Servir para o planejamento e gerenciamento da sustentabilidade;

- Avaliar impactos políticos.

Heller e Ribeiro (2004) afirmam que um grande avanço na discussão sobre indicadores foi o desenvolvimento do indicador denominado "Pegada Ecológica", do inglês "ecological footprint", definido por um cálculo do quanto é necessário de recursos naturais para sustentar o estilo de vida. O mesmo considera a capacidade que o planeta tem de oferecer e renovar tais recursos bem como sua capacidade de absorção de resíduos gerados.

De acordo com Rees (1992) a metodologia original estabelece uma matriz de consumo/uso de terra, que considera:

- Cinco categorias principais do consumo (alimento, moradia, transporte, bens de consumo e serviços); e

- Seis categorias principais do uso da terra (energia da terra, ambiente (degradado) 
construído, jardins, terra fértil, pasto e floresta sob controle).

No Brasil, esta é a ferramenta mais notada e conhecida pelos especialistas que lidam com o conceito de desenvolvimento sustentável (VAN BELLEN, 2005).

Outro índice surgido dentro deste cenário e que é considerado de grande importância na discussão sobre a sustentabilidade de países é o ISE (Índice de Sustentabilidade Ambiental) o qual mede a magnitude das pressões sobre o sistema ambiental, considerando o esgotamento dos recursos naturais e as taxas de poluição. Sua estrutura é baseada em uma média ponderada de 21 indicadores (com 76 variáveis) que sumarizam 5 componentes temáticos (ESTY et al., 2005).

Além destes são muitos os índices e indicadores que surgiram depois do Relatório Brundlant, ou seja, depois da oficialização do conceito de desenvolvimento sustentável, ganhando maior força com a Agenda 21.

Tais indicadores e índices têm um perfil diferenciado daqueles anteriores a estes marcos. Esta diferenciação está desde a inserção da participação pública na elaboração de muitos deles, até a sua visão integrada e conectiva. Observou-se que os indicadores evoluíram ao longo do tempo, bem como evoluiu a percepção de importância dos mesmos.

Isto mostra que indicadores têm se tornado mais fortes e úteis para apoiar discussões e decisões ao mesmo tempo em que se demonstra que toda esta evolução histórica serviu para mostrar que os indicadores de diferentes gerações possuem certa dependência, uma vez que indicadores de primeira geração (ambientais) são necessários para compor os de segunda geração (de sustentabilidade), sendo estes aperfeiçoados para representarem melhor a sistêmica ao qual estão relacionados (terceira geração).

Portanto, é importante saber com maior detalhe a relação entre um indicador ambiental e um indicador de sustentabilidade.

\subsection{Indicadores ambientais - componente da Sustentabilidade}

As discussões sobre sustentabilidade têm a finalidade de analisar as múltiplas relações, causas e impactos de um problema complexo e, deste modo, buscar uma solução estratégica através da elaboração de opções apropriadas de política para o problema em questão (ROTMANS, 2006). Assim, se torna necessária e adequada a abordagem sistêmica, multidimensional e interdisciplinar para lidar com a complexidade do tema.

Esta integração proposta não se mostra apenas uma questão de conexão entre áreas de conhecimento, mas também entre ferramentas, métodos, dimensões (basicamente: econômica, ecológica e social), atores, formuladores de políticas e especialistas (WEAVER; ROTMANS, 
2006). Independentemente dos objetivos e do contexto da política pública que está sendo proposta, o tipo de informação que é demandada deve ser adequada e útil para subsidiar um processo decisório na formulação de alternativas. Por tal motivo é imperativo que se utilize indicadores apropriados ao compor ferramentas de avaliação integrada de sustentabilidade.

Malheiros Philippi e Coutinho, (2008) enfatizam que o papel dos indicadores como ferramenta é o estabelecimento de uma visão de conjunto que exige um processo de avaliação de resultados em relação às metas de sustentabilidade estabelecidas. Com isto, são colocadas condições adequadas de acompanhamento pelas partes interessadas, dando suporte ao processo decisório.

Portanto, ao se descrever a sustentabilidade, muitas vezes se faz uma analogia com um quebra-cabeça, no qual os seus blocos de construção são apresentados como diferentes dimensões e que devem ser combinados por meio de suas interfaces obtendo um encaixe que traga êxito ao retratar uma paisagem única.

Porém a sustentabilidade é mais do que uma agregação padronizada de "peças" e por isso há a necessidade de compreender como realizar os "encaixes" ideais através das interligações dos distintos componentes para refletir a dinâmica do conjunto, devendo-se considerar a abordagem sistêmica e a interdisciplinar.

De qualquer forma, todos os componentes necessários para que isso aconteça devem ser adequados e credíveis. Por tal motivo uma análise sobre a qualidade das informações, ou seja, dos indicadores, torna-se necessária para efetividade e eficácia de uma avaliação de sustentabilidade.

Para melhor entendimento desta relação Briassoulis (2001) explica que indicadores podem ser classificados como indicadores uni e multidimensionais. Segundo o autor os indicadores unidimensionais descrevem uma única dimensão do desenvolvimento sustentável (ex: indicadores ambientais), enquanto indicadores multidimensionais são os indicadores que combinam mais de uma dimensão (ex: uso de energia/pessoa: econômico+social).

Os indicadores multidimensionais são formados pelos unidimensionais. Portanto, uma vez que os indicadores de sustentabilidade são compostos por diferentes indicadores, inclusive os indicadores ambientais, estes últimos se tornam parte integrante e indivisível da estrutura de informação, avaliação e tomada de decisão sobre sustentabilidade.

Malheiros, Phillip Jr. e Aguiar (2005) descrevem exemplos de indicadores de diferentes dimensões e suas medições como:

- Indicadores sociais: nível de emprego, equidade e exclusão social, pobreza e distribuição de renda, bem-estar e qualidade de vida, dentre outros. 
- Indicadores econômicos: padrão de consumo e de produção, uso de energia, desenvolvimento e estrutura econômica, gestão de resíduos, dentre outros.

- Indicadores ambientais: uso sustentável de recursos naturais, clima global, capacidade de suporte de ecossistemas, uso do solo, dentre outros.

- Indicadores institucionais: ciência e tecnologia, governabilidade e papel da sociedade civil, conscientização da comunidade e informação, dentre outros.

No caso do componente ambiental, que é o foco da pesquisa, a utilização de indicadores ambientais deve permitir a análise das condições, mudanças da qualidade ambiental, além de favorecer o entendimento das interfaces da sustentabilidade, possibilitando inclusive a apresentação de tendências, como uma ferramenta de suporte no processo de tomada de decisão e formulação de políticas e práticas sustentáveis.

A dimensão ambiental tem sua importância destacada por Gibson et. al (2005) quando estes colocam que entre vários princípios que direcionam as mudanças à caminho da sustentabilidade, a integridade do sistema sócio-ecológico é um dos quais deve ser seguido, discutido e empregado, considerando a importância da proteção das funções ecológicas das quais dependem a qualidade ambiental e claro, o homem.

Através de um modelo ilustrativo (Figura 4.2) é fácil visualizar as dimensões que basicamente compõem a sustentabilidade e as intersecções entre as áreas, enfatizando a necessidade de interdisciplinaridade e transdiciplinaridade (TODOROV; MARINOVA, 2009), sem intenção de limitar a abrangência do conceito, que permite considerar outras dimensões que se considerem importantes.

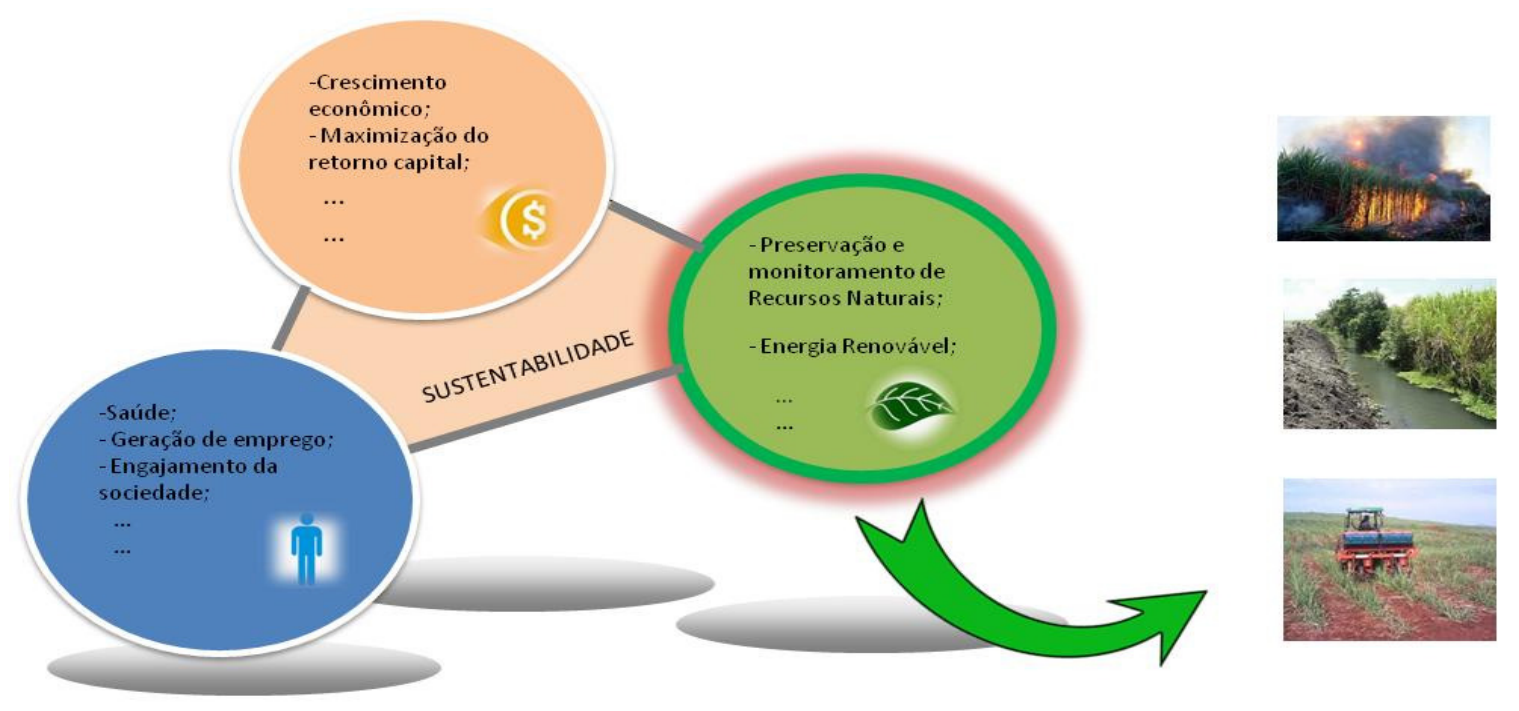

Figura 4.2- Dimensão ambiental como componente da sustentabilidade Fonte: Elaborada pela autora. 
Os indicadores ambientais representam diversos elementos-chave (físicos, químicos ou biológicos) de um ecossistema complexo ou de um problema ambiental, (SAUNDERS; MARGULES;HILL, 1998).

Segundo EEA (2003), indicadores ambientais comunicam os aspectos considerados críticos ou típicos para as inter-relações complexas entre as espécies naturais e os componentes abióticos do sistema ambiental. Munn (1975) define indicadores ambientais como um parâmetro que fornece medidas da magnitude do impacto ou, como expresso por Moreira (1988), uma medida das condições ambientais de uma área ou ecossistema.

De acordo com Danz et al, (2005) os indicadores ambientais podem ser uma ferramenta para medir e avaliar as consequências das atividades antrópicas no sistema biológico; bem como permita que as pessoas ajam sobre questões do meio ambiente (EEA, 1999).

De qualquer forma os indicadores ambientais devem conter informações sobre condições ambientais, locais ou regionais, não se restringindo às medidas de impactos ambientais, uma vez que tais indicadores podem também trazer informações expressas em termos de pressão, estado e resposta (HELLER; RIBEIRO, 2004).

Sua função está em diagnosticar a saúde do ecossistema e fornecer uma ferramenta para monitorar condições e mudanças ambientais ao longo do tempo (JORGENSEN, 2005).

Em outras palavras, indicadores ambientais são ferramentas que podem fornecer informações ao longo do tempo em uma variedade de escalas espaciais que podem mostrar as tendências ambientais, sendo, por tais propriedades, cada vez mais usados como uma maneira simples de observar o complexo ambiente, avaliar o impacto das atividades e direcionar respostas a estes problemas.

É por estes motivos que os indicadores ambientais são vistos como uma ferramenta para desenvolvimento de políticas e decisão ambiental em diferentes escalas, sendo de fundamental importância na formulação dos indicadores de sustentabilidade (IDS) uma vez que, como visto por Malheiros, Phillip Jr. e Aguiar (2005), estes são compostos por indicadores do tipo ambiental, social, econômico e institucional.

Dada esta relação intrínseca com os indicadores de sustentabilidade é de inegável importância a elaboração, seleção e validação de indicadores ambientais por meio de um processo estruturado e coeso, capaz de garantir que as informações colhidas sejam relevantes e principalmente verídicas, ou seja, sejam pertinentes na tomada de decisão e que sejam cientificamente válidos. Para tanto é necessário que alguns princípios sejam considerados, os quais orientam ou avaliam sobre a qualidade de indicadores. 


\subsection{Boas práticas na construção de indicadores}

Desde a Conferência das Nações Unidas sobre o Meio Ambiente e Desenvolvimento em 1992, muitos trabalhos têm sido feitos com intuito de desenvolver ferramentas de informações apropriadas para cumprir o proposto no capítulo 32 da Agenda 21: a integração do meio ambiente e desenvolvimento para a formulação de políticas (UNCED, 1993).

As iniciativas voltadas ao desenvolvimento de informações ambientais vieram por meio de esforços internacionais voltados para o desenvolvimento de estatísticas ambientais.

Foram responsáveis por estas iniciativas a Comissão Econômica Européia, organizações de estatísticas dos Estados Unidos e do Canadá e o Escritório de Estatística das Nações Unidas - EENU (MUELLER, 1992). Ainda segundo Mueller (1992) até hoje o trabalho destas organizações vêm servindo de base para iniciativas no campo das estatísticas ambientais para diversos países.

É evidente a necessidade de informações adequadas, organizadas e disponibilizadas, sendo imprescindíveis para planejar, executar e tomar decisões.

The World Bank (1997) afirma que para o desenvolvimento de indicadores ambientais proveitosos é necessário não só uma percepção de conceitos e definições, mas também um conhecimento profundo das necessidades políticas.

Ainda segundo indicações do World Bank (1997), o principal determinante de um bom indicador é a ligação da medição das condições ambientais com as opções políticas concretas. Estas opções implicam uma relação entre questões ambientais e sociais, sendo que os indicadores devem influenciar na tomada de decisão. Por isso, é essencial que estes indicadores sejam apropriados.

De acordo com a Woerden (2007) indicadores que fornecem informações inadequadas e imprecisas sobre o que está sendo mensurado são considerados indicadores "pobres". Por exemplo, um indicador que reflete uma mudança em longa escala de tempo, quando os decisores necessitam de conhecimento sobre as alterações em curta escala de tempo.

Não obstante, são também considerados indicadores de baixa capacidade de informação para a tomada de decisão adequada aqueles que apresentam apenas a visão técnica de mensuração e tratamento dos dados, ignorando, por exemplo, a dinâmica do construto em observação, sua inferência na capacidade de suporte do meio, a participação do usuário na discussão de sua relevância, enfim, impossibilitando sua utilização para o desenvolvimento de planos e políticas voltadas para a sustentabilidade.

O Quadro 4.2, traz uma comparação entre os perfis dos indicadores tradicionais (pobres) e os indicadores que seguem a abordagem da sustentabilidade, sendo estes os 
buscados pelos atuais processos de gestão e planejamento, no sentido de que decisões sejam amparadas por uma melhor análise, sistêmica, integrada.

De acordo com Sato (1999) os indicadores considerados tradicionais são caracterizados por mensurações estáticas dos parâmetros aferidos, enquanto os indicadores de sustentabilidade trazem adicionalmente aspectos relacionados com a mensuração de questões dinâmicas envolvendo o sistema analisado.

\begin{tabular}{|c|c|c|c|c|c|}
\hline \multicolumn{2}{|c|}{ Indicadores Econômicos } & \multicolumn{2}{|c|}{ Indicadores Sociais } & \multicolumn{2}{|c|}{ Indicadores Ambientais } \\
\hline Tradicionais & Sustentabilidade & Tradicionais & Sustentabilidade & Tradicionais & Sustentabilidade \\
\hline $\begin{array}{c}\text { Renda média; } \\
\text { Renda } \\
\text { percapita }\end{array}$ & $\begin{array}{c}\mathrm{N}^{\mathrm{o}} \text { de horas } \\
\text { trabalhadas/ média } \\
\text { de salário necessária } \\
\text { para as necessidades } \\
\text { básicas; }\end{array}$ & $\begin{array}{c}\text { Testes e } \\
\text { pontuações } \\
\text { padronizados } \\
\text { (exames do } \\
\text { MEC: } \\
\text { Provão...); }\end{array}$ & $\begin{array}{c}\mathrm{N}^{\circ} \text { estudantes } \\
\text { treinados p/ os } \\
\text { trabalhos disponíveis } \\
\text { na comunidade; } \\
\mathrm{N}^{\mathrm{o}} \text { estudantes que } \\
\text { ingressam na } \\
\text { faculdade e retornam à } \\
\text { sua comunidade; }\end{array}$ & $\begin{array}{c}\text { Níveis } \\
\text { ambientais de } \\
\text { poluição do ar, } \\
\text { água, medidos } \\
\text { geralmente em } \\
\text { ppm ou } \\
\text { poluentes } \\
\text { específicos; }\end{array}$ & $\begin{array}{l}\text { Habilidade do } \\
\text { ecossistema de } \\
\text { processar e } \\
\text { assimilar } \\
\text { poluentes; }\end{array}$ \\
\hline $\begin{array}{c}\text { Taxa de } \\
\text { desemprego; } \\
\mathrm{N}^{\circ} \text { de } \\
\text { empresas; } \\
\mathrm{N}^{\circ} \text { empregos; }\end{array}$ & $\begin{array}{l}\text { Elasticidade do } \\
\text { mercado de } \\
\text { trabalho; } \\
\text { Habilidade do } \\
\text { mercado de ser } \\
\text { flexível em tempos } \\
\text { de mudanças; }\end{array}$ & $\begin{array}{l}\mathrm{N}^{\mathrm{o}} \text { de eleitores } \\
\text { registrados; }\end{array}$ & $\begin{array}{c}\mathrm{N}^{\mathrm{o}} \text { de eleitores que } \\
\text { votam nas eleições; } \\
\mathrm{N}^{\mathrm{o}} \text { de eleitores } \\
\text { "engajados" } \\
\text { politicamente; }\end{array}$ & $\begin{array}{l}\text { Toneladas de } \\
\text { resíduos sólidos } \\
\text { produzidos; }\end{array}$ & $\begin{array}{l}\text { Vol. de material } \\
\text { reciclado por } \\
\text { pessoa/total de } \\
\text { resíduos sólidos } \\
\text { produzidos (uso } \\
\text { cíclico das fontes } \\
\text { de recursos); }\end{array}$ \\
\hline $\begin{array}{c}\text { Tamanho da } \\
\text { economia } \\
\text { medido por } \\
\text { índices como } \\
\text { PIB. }\end{array}$ & $\begin{array}{c}\text { Maior } \\
\text { independência } \\
\text { financeira local, } \\
\text { possível; }\end{array}$ & & & $\begin{array}{c}\text { Energia per } \\
\text { capita utilizada; }\end{array}$ & $\begin{array}{l}\text { Energia renovável } \\
\text { /energia não } \\
\text { renovável; } \\
\text { Quantidade total } \\
\text { de energia usada. }\end{array}$ \\
\hline
\end{tabular}

Quadro 4.2- Diferença entre indicadores tradicionais e de sustentabilidade Fonte: Adaptado de Sato (1999).

Para conseguir bons indicadores alguns critérios de boas práticas devem ser considerados, como, por exemplo, aqueles formulados pelo The World Bank (1997) e OECD (1993), e utilizados pelo modelo GEO - Global Environment Outlook (WOERDEN, 2007) quais são comumente utilizados para processos de seleção de bons indicadores. De acordo com estes critérios, indicadores devem:

a) Ser construído dentro de um modelo conceitual aceito;

b) Ser claramente definido (fácil de entender e interpretar);

c) Mostrar tendências ao longo do tempo;

d) Ser cientificamente credível e com base em dados de alta qualidade;

e) Ser politicamente relevantes;

f) Ser relevantes para os usuários, politicamente aceitável e uma base para ação;

g) Ser sensível às mudanças ambientais e atividades humanas;

h) Fornecer base de comparação internacional provendo um limiar/valor de referência; 
i) Ser objeto de agregação (de uso doméstico à comunidade e da comunidade à nação);

j) Ser objetivo (independente da coleta dos dados);

k) Ter exigências razoáveis em relação aos dados (ou dados que estão disponíveis ou dados que podem ser coletados a baixo custo); e

1) Ser limitados em números.

Este último princípio de boas práticas é uma consideração importante quanto à visão sobre o número adequado de indicadores, isto porque, uma quantidade muito grande destes pode trazer uma "confusão" na interpretação, enquanto um número pequeno pode limitar o escopo do entendimento (MEADOWS, 1998; BOSSEL, 1999, WOERDEN, 2007).

$\mathrm{Na}$ tentativa de resolver este problema, é importante considerar um conjunto de assuntos prioritários para que correlacionem ao conjunto de indicadores.

De acordo com CSIRO (1999), um bom indicador ambiental deve possuir os seguintes requisitos:

a) Ter um significativo e legítimo valor científico;

b) Representar um aspecto ambiental de importância para a sociedade;

c) Demonstrar algo de importância e de entendimento imediato;

d) Ter um processo de mensuração legítimo e prático;

e) Ajudar a focar informações para responder questões importantes; e

f) Ser eficiente e efetivo no apoio ao processo de tomada de decisão.

No processo de seleção de indicadores Heller e Ribeiro (2004) explicam que os indicadores devem ser selecionados de forma que contribuam para atender os seguintes princípios básicos:

i. Capacidade de identificar os elementos de pressão sobre o meio ambiente, o estado decorrente dessas pressões e as respostas sociais em relação às mesmas, informando tanto o estágio atual como as tendências de qualidade deste meio e dos estoques de recursos naturais;

ii. Capacidade de auxiliar o processo de tomada de decisões nas instâncias governamentais e em segmentos sociais, auxiliando na definição de objetivos e metas da política de meio ambiente;

iii. Capacidade de interagir de forma sistêmica apresentando como, por exemplo, a influência das respostas sobre os elementos de pressão e esses sobre o estado do meio ambiente;

iv. Capacidade de associar os aspectos ambientais aos processos econômicos e sociais. 
Após análise desses princípios, os indicadores selecionados devem demonstrar a qualidade ambiental, e poderão ser relacionados aos principais fatores de pressão, estado e resposta. São exemplos de fatores relacionados à:

- Pressão: emissões de poluentes pelo setor produtivo, desmatamentos, urbanização, geração de esgotos e resíduos;

- Estado: preservação da fauna e da flora, qualidade do ar, das águas e do solo, indicadores de níveis de saúde; e

- Resposta: controle, incentivos, capacitação, produção científica e tecnológica, ações decorrentes de políticas públicas, programas, projetos.

Para que os indicadores sirvam para um processo de tomada de decisões que atenda as necessidades, estes devem refletir as diversas perspectivas que envolvem os múltiplos grupos de interesse, tais como: cidadãos, o setor público e privado, e os próprios tomadores de decisão (GALLOPÍN, 1997; GOMES, MARCELINO, ESPADA, 2000; SANTOS, 2004).

Desta forma, o processo participativo dos vários atores abarcados se torna essencial, tanto no momento de definir as metas e prioridades para o indicador quanto no processo de comunicação do indicador, com a efetiva compreensão e interpretação dos resultados em relação aos valores e visões destes atores.

Outras recomendações para a obtenção de um indicador ideal, úteis em planejamentos e medidas para o desenvolvimento sustentável podem ser verificadas no Quadro 4.3.

\begin{tabular}{cl}
\hline Requisitos & Explicação \\
\hline Representatividade & Refere-se à capacidade de retratar os problemas da área de estudo. \\
\hline Validade científica & Em suma, tem relação à forma de coleta e elaboração do dado. \\
\hline Fonte de informação & $\begin{array}{l}\text { Deve-se observar a confiabilidade da sua origem (se de órgão oficial, instituição } \\
\text { creditada, organização não governamental, jornal, etc.). }\end{array}$ \\
\hline Relevância & $\begin{array}{l}\text { O indicador deve possuir concordância com o quadro legislativo do governo local } \\
\text { para possibilitar a avaliação e monitoramento do progresso no sentido de alcançar } \\
\text { resultados para a sociedade. }\end{array}$ \\
\hline Valores de referência & $\begin{array}{l}\text { Para que o usuário possa estabelecer comparações e julgar a relevância do seu } \\
\text { valor. }\end{array}$ \\
\hline Conformidade & $\begin{array}{l}\text { Deve-se averiguar o tempo decorrido entre a coleta do dado e a realidade que se } \\
\text { deseja representar. Neste aspecto, é evidente que para cada temática, há um } \\
\text { intervalo de tempo aceitável, que deve ser julgado pelo seu especialista. }\end{array}$ \\
\hline Redundância & $\begin{array}{l}\text { Deve se tomar cuidado para que o indicador não a apresente, ou seja, que } \\
\text { diferentes dados coletados não expressem a mesma informação. }\end{array}$ \\
\hline Sensibilidade às & $\begin{array}{l}\text { A medida que ocorrem as alterações no ambiente, mesmo que pequenas, a resposta } \\
\text { do dado é imediata, mudando o seu valor; e se for de natureza preventiva que seja } \\
\text { capaz de sinalizar a degradação antes da ocorrência de sérios danos. }\end{array}$ \\
\hline Séries temporais & $\begin{array}{l}\text { Se a sensibilidade às mudanças ao longo do tempo, pode-se gerar séries temporais } \\
\text { de dados (lineares, cíclicos ou sazonais), entendidas como ótimos tradutoras dos } \\
\text { fenômenos de diferentes dinâmicas em um determinado tempo. Quando for } \\
\text { importante a analise da evolução, os indicadores devem ter a capacidade de } \\
\text { expressar as mudanças em uma escala de tempo compatível com os problemas. }\end{array}$ \\
\hline
\end{tabular}




\begin{tabular}{|c|c|}
\hline Abrangência & $\begin{array}{l}\text { No que se refere a dados espaciais, o indicador deve apresentar limites bem } \\
\text { definidos no espaço, de forma a facilitar, geográfica e operacionalmente, o } \\
\text { gerenciamento das propostas do planejamento. }\end{array}$ \\
\hline Conectividade & $\begin{array}{l}\text { Conectividade do indicador com outros do meio, ou seja, os elos entre as diversas } \\
\text { informações e as respostas integradas às suas mudanças. }\end{array}$ \\
\hline Integração & $\begin{array}{l}\text { É importante observar se o indicador é integrador, se tem a capacidade de sintetizar } \\
\text { informações de vários outros indicadores. }\end{array}$ \\
\hline Tipo de Informação & $\begin{array}{l}\text { Informação prescritiva: deve-se considerar se a informação é prescritiva - aquela } \\
\text { que é analítica e apresenta recomendações ao desenvolvimento de alternativas, } \\
\text { constituindo um bom indicador. } \\
\text { Informação descritiva: deve-se considerar se a informação é descritiva - restringe- } \\
\text { se à descrição das propriedades do meio, sem a pretensão de fornecer subsídios } \\
\text { diretos à tomada de decisão. }\end{array}$ \\
\hline Disponibil & $\begin{array}{l}\text { Informação sobre o indicador, sem perda de tempo que impeça ou dificulte o } \\
\text { planejamento. }\end{array}$ \\
\hline $\begin{array}{l}\text { municação } \\
\text { dos indic }\end{array}$ & $\begin{array}{l}\text { Comunicados de forma que envolva o público, por gráficos e informações } \\
\text { contextuais, auxiliando na compreensão e interpretação da medição. }\end{array}$ \\
\hline Custo razoável & $\begin{array}{l}\text { Corresponde ao valor ideal para obtenção da informação em função da quantidade } \\
\text { de dados, da unidade de área e da escala de trabalho. Em suma, pretende-se que } \\
\text { haja uma relação custo/benefício }\end{array}$ \\
\hline Participação popular & Em algum momento, ou na elaboração ou revisão dos indicadores. \\
\hline $\begin{array}{l}\text { Atualização e } \\
\text { Divulgação }\end{array}$ & $\begin{array}{l}\text { Os dados precisam ser coletados e reportados regularmente, devendo haver um } \\
\text { tempo mínimo entre a coleta e a reportagem, para garantir a atualidade e utilidade } \\
\text { para o usuário. }\end{array}$ \\
\hline Fácil compreensão & $\begin{array}{l}\text { Indicadores devem ser simples e fáceis de compreender para informar o grupo de } \\
\text { pessoas que tomará as decisões quantos aos rumos do planejamento. }\end{array}$ \\
\hline $\begin{array}{l}\text { Modelo conceitual } \\
\quad \text { estrutural }\end{array}$ & $\begin{array}{l}\text { Usado como guia para o desenvolvimento e estruturação de um conjunto de } \\
\text { indicadores, de uma forma coerente. Sem ele, o conjunto se torna uma mistura } \\
\text { eclética de indicadores, sem qualquer justificação clara para a sua seleção. }\end{array}$ \\
\hline \multicolumn{2}{|c|}{$\begin{array}{l}\text { Quadro 4.3- Condições para um indicador ideal } \\
\text { Fonte: Baseado em Santos (2004), APHO - The Association Of Public Health Observatorie. (2008), ACOS - } \\
\text { Advisory Committee on Official Statistics, 2009, Martínez (2009), SIBIS - Statistical Indicators Benchmarking } \\
\text { the Information Society ( 2003) e CSO (Central Statistical Office - Ireland, 2008). }\end{array}$} \\
\hline
\end{tabular}

Mesmo na intenção de demonstrar todos os princípios de boas práticas que se espera encontrar em um conjunto de indicadores, é unânime na opinião dos autores citados que a possibilidade de encontrar em absoluto todos estes critérios é diminuta.

Ao julgar os critérios que sejam considerados mais importantes pelos envolvidos se torna possível desenhar e selecionar indicadores que auxiliem a sociedade a tomar decisões e realizar planejamentos, isto porque possibilitam entender o que está acontecendo no ambiente analisado através de medidas que refletem valores de uma sociedade, ao mesmo tempo em que o que é medido também pode se tornar um valor para esta mesma sociedade.

\subsection{O papel da Informação Ambiental}

De acordo com o capítulo 40 da Agenda 21, no desenvolvimento sustentável, cada pessoa é usuário e provedor de informação, desde que adequadamente apresentadas, sendo que a necessidade de informação existe em todos os níveis, desde o de tomada de decisões ao individual (UNCED, 1993). 
O papel da informação se refere em possibilitar o planejamento, indicando onde e o que está disponível. Já os sistemas de informação buscam auxiliar ao apontar demandas de informação ou identificar as existentes, sendo sempre melhor observar o que usuários desejam com o intento em atender a estas necessidades (LIMA, 2008).

Isto ressalta então a necessidade do aperfeiçoamento, disponibilidade e utilização de informações (indicadores) para o desenvolvimento de políticas, através da definição de prioridades e avaliação dos resultados, tanto por parte do governo como pela sociedade.

Neste contexto, os indicadores ambientais vêm para apresentar informações resultantes de situações simples ou complexas, desempenhando um importante papel no apoio ao processo decisório (GUTIÉRREZ-ESPELETA, 1998).

The World Bank (1997) afirma que o desenvolvimento de indicadores ambientais úteis demanda não só uma compreensão de conceitos e definições, mas também um maior conhecimento das necessidades políticas.

Ainda de acordo com a CCDRA (2004) e a EUROSTAT (2004) a formulação de indicadores de sustentabilidade deve corresponder às prioridades e necessidades dos usuários, tendo como finalidade descrever o progresso do desenvolvimento sustentável, engajar políticas relevantes a este desenvolvimento, aumentar a conscientização dos atores desenvolvidos e alertar e prevenir danos nos vários setores relacionados.

Segundo Jesinghaus (1999), os indicadores são poderosas ferramentas para a tomada de decisão quando adequados, sendo ao mesmo tempo uma péssima "receita" para formulação de políticas quando o contrário. Em outras palavras, um bom indicador deve fornecer informações com qualidade e focar em aspectos que são tidos como relevantes por seus usuários ao mesmo tempo em que deve servir como elo da medição de condições ambientais com opções políticas concretas.

De acordo com a EEA (2003), em relação à formulação de políticas, indicadores ambientais são usados para:

i. Permitir aos decisores políticos avaliar a gravidade dos problemas ambientais;

ii. Identificar fatores-chave que causam pressão sobre o ambiente e assim apoiar o desenvolvimento de políticas e definição de prioridades;

iii. Monitorar a implicação e a eficácia das respostas políticas; e

iv. Sensibilizar a opinião pública sobre questões ambientais.

Moldan (1997) e Winograd e Farrow (2009) expõem uma visão geral do ciclo de tomada de decisão em função do uso de indicadores em cada uma dessas fases:

- Identificação do problema; 
- Avaliação do problema;

- A sensibilização do público (reconhecimento do problema);

- A formulação de políticas;

- Implementação de políticas; e

- Avaliação de políticas.

Do mesmo modo, é imprescindível identificar e corrigir problemas que acarretam o uso ineficiente da informação ou ao não uso de serviços de informação, como por exemplo, aqueles relativos à falta de confiabilidade dos dados, a não disponibilidade da informação, à forma imprópria de apresentação, entre outros (LIMA, 2008).

Lima (2008) expressa que todo sistema de informação deve reunir informações pertinentes, capazes de responderem às questões propostas por seus usuários, independente de quem sejam estes, e quais informações, quando reunidas, devem ser criteriosamente escolhidas, organizadas, analisadas, consolidadas e eventualmente explanadas.

Adicionalmente, (O’BRIEN, 2004) comenta que o serviço de informação (entidade organizada que participa da transferência da informação) deve organizar documentos e sínteses para divulgar informações consolidadas e tratadas, entre os tomadores de decisão e àqueles que estas decisões vão interessar e/ou afetar.

Isto tudo possibilita a formulação de políticas e diretrizes, fazendo com que o poder público consiga atingir seus objetivos que, de acordo com Lima (2008, p. 47), são:

\footnotetext{
“(...) servir a coletividade, ocasionando maior bem-estar social e acelerando o processo de desenvolvimento. O Estado intervindo para orientar, estimular, controlar, proibir, subsidiar, produzir, comprar, vender, operar em serviços e setores que de interesse nacional e naqueles em que a iniciativa privada não está sensibilizada a atuar. Ou ainda, o Estado regulando os serviços ao cidadão.”
}

O Estado, como órgão de defesa dos interesses da sociedade, deve basear sua ação em informações adequadas e consolidadas para que possibilite melhoria do nível de vida da sociedade e também a defesa dos interesses desta. Ao se falar em meio ambiente isto não é diferente, tendo em vista a crescente necessidade de compreender a conjuntura ambiental e de ponderar sobre a sua deterioração, sendo que este quadro é intrinsecamente ligado ao desenvolvimento sustentável.

Além do seu papel como informação ambiental para apoio de discussões e tomada de decisão, os indicadores ambientais têm um papel de fundamental importância na conscientização e mobilização da sociedade; na elaboração de um planejamento sustentável; 
no monitoramento; e na avaliação da sustentabilidade (MALHEIROS, PHILLIP JR. e AGUIAR, 2005).

Estes indicadores devem ser desenvolvidos e utilizados pelas instituições sociais, dirigindo as atividades humanas a uma sociedade sustentável, consequentemente fazendo cumprir valores sociais representativos.

Deste modo, Sheng (1999) afirma que o trabalho sobre indicadores é um processo social a partir do momento que diferentes segmentos de uma sociedade identificam e concordam sobre aspectos importantes na qualidade de vida humana, bem como estabelecem objetivos e prazos para atingir os mesmos. Adicionalmente, ainda segundo o autor, o trabalho sobre indicadores deve ter uma relação de vínculo entre os escritórios oficiais de estatística, os meios de comunicação e a sociedade com intuito de aumentar a consciência dos envolvidos sobre as questões ambientais, econômicas e sociais.

Em outras palavras, um debate social bem informado deriva da disponibilidade e publicidade da informação. De fato os escritórios oficiais de estatística devem fornecer indicadores para expressar os aspectos identificados socialmente como os mais importantes. Assim também os meios de comunicação, enquanto instituições sociais, através da publicidade, devem demonstrar estes indicadores e seus objetivos, facilitando debates sociais que estarão em curso e a representação da sociedade.

A sociedade, por fim, deve verificar se as instituições sociais existentes promovem ou detêm o progresso para os objetivos estabelecidos. Durante este processo é ideal que sejam utilizados modelos e métodos na criação e/ou planejamento de tais indicadores.

São exemplos destes modelos o P-E-R (Pressão-Estado-Resposta) que foi desenvolvido na década de 1970 pelo canadense Anthony Friend, e posteriormente adotado pela Organização para a Cooperação e Desenvolvimento Econômico (OECD, 1993), sendo este modelo base para outros como P-E-I-R (onde I é Impacto) e depois o F-P-E-I-R (onde F é Força-Motriz) usados pelo Modelo Geo (Global Environment Outlook) (Woerden, 2007).

Outro exemplo é o indicado pela ISO (International Standardization Organization), que compõe a norma ISO-14031 e propõe a seleção e aplicação de indicadores nas organizações objetivando o gerenciamento do desempenho ambiental de uma empresa. Esta norma foi publicada em 2004 e os indicadores relacionados devem ser específicos para uma determinada área, sendo relevantes, de fácil comprovação, válidos cientificamente e devem ter custos de medição aceitáveis (LEMOS, 2007).

Tais modelos dão suportes à integração dos indicadores ambientais, viabilizando uma simplificação das complexas relações presentes, favorecendo o processo de tomada de 
decisão, bem como favorecendo que a construção destes indicadores venha a ser incorporada pelos sistemas de gestão da saúde pública e ambiental e pela sociedade no seu dia a dia.

Para a gestão ambiental, estes modelos de indicadores devem apoiar os sistemas de gestão de forma a orientar a aplicação de novas metas e ações mediante as mudanças observadas nestes indicadores.

Assim, indicadores adquirem força quando são efetivamente aplicados na comunicação e nos processos de decisão, não havendo sentido para sua construção se os agentes envolvidos não confiarem neles para orientar políticas e guiar a tomada de decisões, desde pontos relacionados a ações e influências de alcance individual, até as decisões mais amplas, relacionadas ao coletivo (GUTIÉRREZ-ESPELETA, 1998; BOSSEL, 1999; WINOGRAD; FARROW, 2009).

Porém, mesmo observando estas necessidades, muitos trabalhos sobre ou com indicadores nem sempre os aplicam em todo seu potencial e embora muito seja desejado, o uso efetivo de indicadores não é sempre óbvio. O empoderamento dos indicadores depende de muitos fatores, incluindo: análise da complexidade através de uso de indicadores, maior domínio sobre indicadores por múltiplos agentes envolvidos, e a inclusão de indicadores no processo de orçamentos.

É possível notar motivações que justificam a dependência destes fatores, tais como:

(i) Teoria de Sistemas indica interações complexas que aparecem no contexto de sustentabilidade.

Indicadores são meios de articular esta complexidade. Com este fim, muitos modelos têm sido gerados e voltados para o propósito de identificar indicadores que reflitam o que está acontecendo no sistema.

Assim, entender o potencial de cada componente, por exemplo, ambiental, social e econômico, e seus respectivos indicadores, é essencial para melhor idealização dos modelos de interação.

(ii) Essencialmente, indicadores ganham força quando são usados por aqueles responsáveis pela sustentabilidade.

Isto ocorre mais efetivamente quando os usuários têm domínio intelectual sobre indicadores e quando os indicadores são relevantes e refletem seu campo de ação.

Este domínio pode ser obtido por diferentes maneiras: envolvimento direto dos usuários e agentes envolvidos no processo de desenvolvimento de indicadores, cultivando domínio no uso de indicadores para comunicação estratégica; e capacidade de instituições e pessoas para adotar indicadores. 
(iii) Lucros estão progressivamente sendo feitos com a inclusão de indicadores em processos orçamentários.

A avaliação do desempenho pode qualitativamente usar um conjunto de critérios ou usar abordagens quantitativas baseadas no desempenho de indicadores e resultados esperados.

No contexto do governo, tais informações são usadas para dar suporte às tomadas de decisão nas prioridades departamentais anuais e estimativas orçamentárias.

Entre os desafios da inclusão da medição de desempenho nos processos orçamentários estão: falta de medidas consistentes, obtenção de resultados de dados direcionados, mudança de prioridades, estilos de gerenciamento que são reativos ao invés de pró-ativos, e prioridades de curto prazo.

Neste contexto, o empoderamento dos indicadores tem relação com a seleção, simplificação de fenômenos complexos e comunicação de informações entre os atores envolvidos.

Ainda que a formulação, análise, interpretação e validação dos indicadores sejam complexas, estes indicadores são considerados informações essenciais que auxiliam tanto na avaliação do sistema em estudo no presente momento, como na construção de cenários na formulação e implantação de melhores práticas e políticas no caminho da sustentabilidade.

De tal forma, por meio de indicadores adequados, questões complexas de gestão se tornam mais simples, transparentes e acessíveis, facilitando assim a conscientização da sociedade e norteando os tomadores de decisão.

Sendo assim, o que se espera de um indicador ou índice para que apoie a discussão de sustentabilidade é que este se refira aos elementos atinentes a sustentabilidade de um sistema e tornem claros seus objetivos, sua base conceitual e seu público usuário (SICHE et al., 2007; SHIELDS; SOLAR; MARTIN, 2002; REED; FRASER; DOUGILL, 2006).

Com o objetivo de contribuir com as discussões acerca da sustentabilidade do etanol de cana-de-açúcar, bem como direcionar de maneira embasada a formação de um conjunto de indicadores ambientais que sirva, juntamente com as discussões dos demais componentes da sustentabilidade, de sustentáculo para políticas públicas voltadas para a sustentabilidade desta atividade, o presente estudo apresentou neste capítulo uma revisão acerca da atividade sucroalcooleira e suas interfaces com o componente ambiental. 


\section{ETANOL E MEIO AMBIENTE}

O Etanol, também conhecido como álcool, é uma substância orgânica derivada de processos de fermentação de biomassa que tem seu uso observado em diversos produtos, desde bebidas, perfumes, alimentos, dentre outros.

No Brasil o Etanol é também largamente utilizado como combustível para motores de combustão interna, onde o produto ganhou, ao longo do tempo, bastante notoriedade e representatividade dentro da matriz energética nacional.

Algumas das principais motivações para este resultado são as características de fonte energética renovável, a possibilidade de substituição de outros combustíveis como a gasolina (em motores veiculares) e os óleos (em caldeiras para produção de energia), contribuindo assim, tanto ao meio ambiente, com a redução de emissões em comparação a outras fontes utilizadas, quanto para a economia, com geração de renda, melhoria dos quadros energéticos e redução da dependência de fontes não renováveis, de maneira especial o petróleo.

Contudo, é importante ressaltar que os benefícios da atividade sucroalcooleira não eliminam os impactos negativos desta atividade, em especial no que tange as questões socioambientais envolvidas nos processos de produção e consumo. Tal perspectiva fica ainda mais complexa ao analisar a atividade sob a ótica da sustentabilidade integrada.

Neste capítulo são abordados elementos do histórico da atividade no Brasil, com especial enfoque na produção e consumo do etanol de cana-de-açúcar, levantando programas e planos governamentais, evolução histórica no país e no Estado de São Paulo.

Não obstante, a pesquisa apresenta as interfaces da atividade sucroalcooleira com algumas legislações ambientais pertinentes nas esferas estaduais e federais como forma de verificar a aptidão destas na condução da sustentabilidade.

A pesquisa traz também os impactos ambientais e os principais pontos discutidos sobre a sustentabilidade da atividade objetivando consolidar suas bases para a composição e debate das necessidades de um quadro de indicadores ambientais consistente para contribuir para a avaliação integrada da sustentabilidade à atividade.

\subsection{Histórico da agroindústria sucroalcooleira}

A atividade sucroalcooleira é historicamente de grande importância para o Brasil, dado seu peso para a formação política, econômica e social do país. Seu surgimento data da colonização portuguesa onde, por muito tempo o açúcar, um de seus subprodutos, se mostrou 
a principal atividade dentro da economia agroexportadora colonial, constituindo, até hoje, um importante setor para o país. (GREMAUD; VASCONCELLOS; TONETO, 2005)

Apesar de toda sua abrangência econômica e sua importância para a caracterização social do país a atividade sucroalcooleira brasileira observou quadros de instabilidade ao longo de seu desenvolvimento histórico, principalmente no que tange o aspecto econômico, com crises cíclicas envolvendo cenários de superprodução e depreciação de preços, crises econômicas mundiais, concorrências externas, dentre outras (CERQUEIRA LEITE, 2010).

De fato, dentro do contexto histórico da atividade não se observam preocupações com outros aspectos envolvidos na atividade (tais como o social e o ambiental) que motivassem discussões sobre políticas e gestão do setor.

Já sobre o aspecto econômico, dado o peso geopolítico da atividade, a história demonstra uma intensa atuação do governo em seu socorro nos momentos de crise, com o objetivo de minimizar os efeitos nocivos e mesmo estimular seu crescimento. Estes estímulos foram executados basicamente através de políticas regulatórias e protecionistas, tais como garantias de preços, compra de excedentes produtivos, etc. (CERQUEIRA LEITE, 2010).

Como aborda Vian (2003) é possível observar a existência de ao menos quatro grandes fases do desenvolvimento da atividade sucroalcooleira, cuja ação política do estado teve participação efetiva. Na primeira fase observa-se a atuação da Coroa Portuguesa como sócia na formação de engenhos e produção de açúcar e detendo os direitos de comercialização.

Vian (2003) expressa que, como consequência da observação de uma oportunidade de mercado esta fase embrionária deu lugar a uma segunda fase de expansão da atividade com incentivo à produção.

Contudo, este incentivo observou limitações significativas devido ao volume de taxas para a comercialização do produto.

Com a independência do Brasil observa-se uma terceira fase, pautada em políticas liberais para investimentos e comercialização, com fortes incentivos para a exportação para o setor que passou a sofrer com problemas de alta sazonalidade produtiva.

De acordo com Vian (2003) este problema fora combatido, já nos anos de 1930, com uma política intervencionista com a atuação do governo no planejamento e controle da produção sucroalcooleira. Um marco do período foi a criação do IAA - Instituto do Açúcar e Álcool que surge como agente regulamentador do setor, voltado para controle da produção do açúcar e modernização, expansão e fomento às exportações da agroindústria sucroalcooleira.

Contudo, o marco definitivo para a alavancagem do setor foi a criação, em 1975 do Programa Nacional do Álcool (PROALCOOL), criado para atender a uma demanda 
específica, qual seja, reduzir a dependência nacional dos combustíveis à base de petróleo, marcando a quarta fase.

Tal necessidade se motivou pela crise que se abateu sobre o mundo nos anos de 197374 com a elevação dos preços mundiais do petróleo e consequente impacto sobre toda a estrutura econômica das nações com matrizes energéticas dependentes deste insumo. (GREMAUD; VASCONCELLOS; TONETO, 2005)

Como tratado por Vian (2003) o etanol como combustível naquela época já era utilizado como aditivo à gasolina, num processo que ocorria desde o início da década de 1930, contudo, com a criação do PROALCOOL a proporção de adição saltou de 5\% para 25\%, sendo que, por volta de 1978 começaram a surgir os primeiros veículos movidos totalmente a etanol (na época denominado álcool).
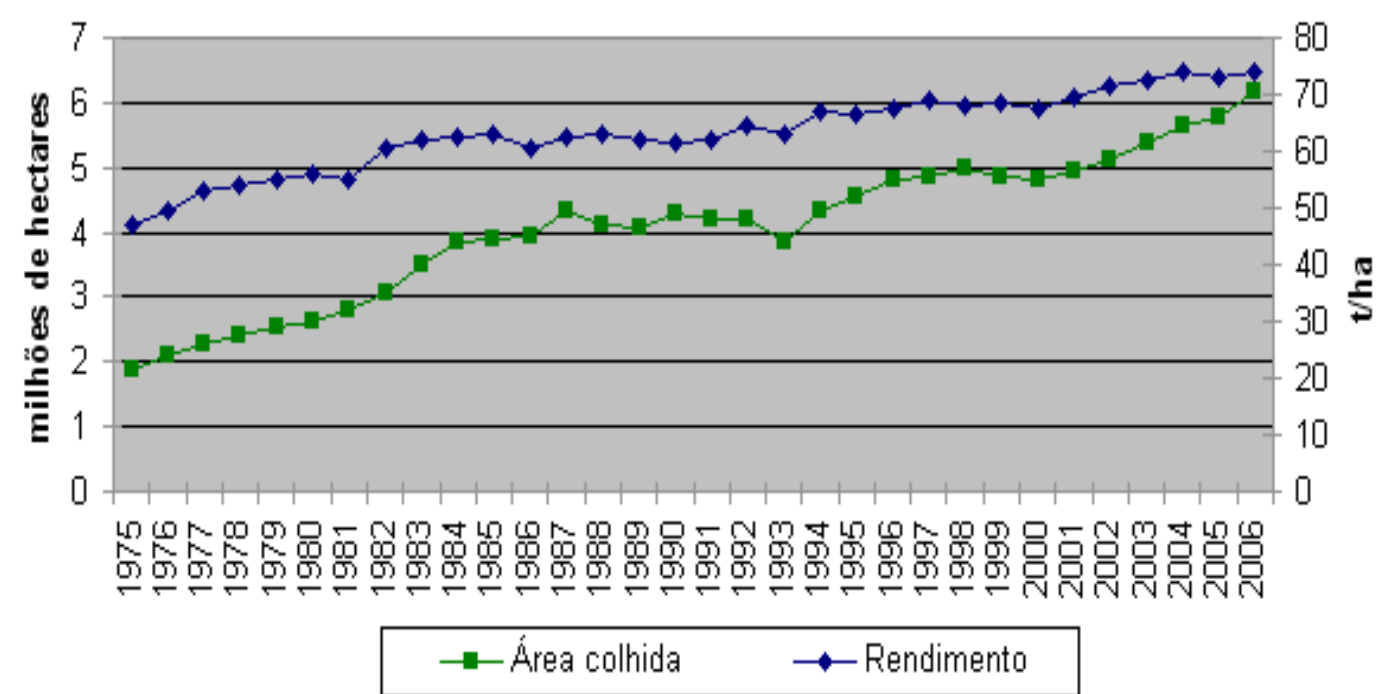

Gráfico 5.1- Evolução histórica da área plantada de cana-de-açúcar no Brasil Fonte: Aguiar et al (2009).

Em decorrência da nova demanda e das tendências de mercado para o produto, bem como dos incentivos à instalação de unidades produtoras o etanol ganhou impulso na época, fazendo com que o volume de área plantada de cana-de-açúcar tivesse uma grande elevação, como pode ser observado no Gráfico 5.1.

Já em 1979, com a segunda crise do Petróleo a atividade ganhou ainda mais respaldo dentro da política energética nacional, com incentivos à instalação de destilarias (produtoras de etanol) e melhorias nas estruturas de cobrança e fixação de preços (regulados pela IAA), bem como a consolidação de incentivos à venda de carros movidos a etanol que, em 1989 chegaram a representar 75\% dos automóveis vendidos no período. (ANFAVEA, 2007) 
Entretanto, após a década de 1980 o setor passou por um longo período de redução da produção do etanol, devido a problemas com a redução dos preços do petróleo e a queda dos preços do etanol, incertezas nas políticas setoriais, bem como da elevação dos preços internacionais do açúcar, que fizeram com que a atividade sucroalcooleira se voltasse novamente para um cenário agroexportador de commodities (açúcar).

A escassez do etanol fez com que o produto tivesse uma sensível queda em importância que foi sentida em toda a década de 1990. O quadro de incerteza nas políticas e as tendências de mercado culminaram com a extinção do IAA e início do processo de desregulamentação do setor sucroalcooleira finalizado em 1999. (VIAN, 2003).

O processo que ficou conhecido como desregulamentação do setor sucroalcooleiro foi a retirada da postura de estado-regulador que se caracterizou dentro do país desde os anos 1930 até o final do século, onde, através de políticas de controle o estado implementava mecanismos e efetivamente gerenciava os aspectos econômicos da atividade, tais como: volume de produção de cana-de-açúcar, preços praticados, percentual destinado à produção de álcool e açúcar, dentre outros.

O Proálcool deixou, contudo, diversos produtos para a atividade, frutos de pesquisas e novas tecnologias para plantio, tratamento, colheita e uso dos insumos do setor, tais como os citados por Vian (2003):

- Uso de controle biológico;

- Desenvolvimento e seleção de novas variedades de cana-de-açúcar;

- Otimização dos processos de colheita e transporte (mecanização);

- Cogeração de energia elétrica;

- Processos de fertirigação das lavouras;

- Melhorias nos processos de fermentação, dentre outros.

Como é possível observar no Gráfico 5.1 anterior, desde a implementação do Próalcool os níveis de rendimento da produtividade da atividade foram vertiginosamente elevados, demonstrando o acúmulo de expertise acumulado pelo setor no Brasil.

Paralelo ao movimento de maximização da produção e consolidação do etanol, são intensificadas as preocupações com o esgotamento das fontes de energia não renováveis, em especial do petróleo, dada a elevação da demanda mundial, igualmente aos impactos provenientes de sua utilização. Tal quadro, juntamente com a desregulamentação do setor e o surgimento dos veículos bicombustíveis fez com que o etanol se consolidasse como uma alternativa atrativa para substituição da gasolina. 
Atualmente, segundo a ANFAVEA (2010) 94,55\% do total de automóveis comercializados no Brasil de janeiro a outubro de 2010 são movidos tanto a etanol quanto a gasolina (comumente conhecidos como veículos flex).

A cana-de-açúcar destinada à produção do etanol também experimentou este crescimento. Como observa a ÚNICA (2010a) o Brasil é atualmente o primeiro no ranking mundial de produção de cana-de-açúcar, com mais de 569 milhões de toneladas na safra 2008/09.

Ainda segundo a ÚNICA (2010b) da safra de 1990/91 para a safra de 2008/09 houve um crescimento de $421,55 \%$ na produção de cana-de-açúcar no país.

Como é possível observar pelo Gráfico 5.2 o Estado de São Paulo contribui com grande parte desta produção, respondendo por 63,3\% do total de cana-de-açúcar produzida no país, sendo que, no mesmo período de 1990/91 a 2008/09 o crescimento da produção no estado foi de 566,45\%. (ÚNICA, 2010d).

A produção do etanol contribui significativamente para este crescimento. De acordo com a ÚNICA (2010c), de 1990/91 a 2008/09 a produção de etanol cresceu 238,93\% ultrapassando a barreira dos 27,51 bilhões de litros por safra.

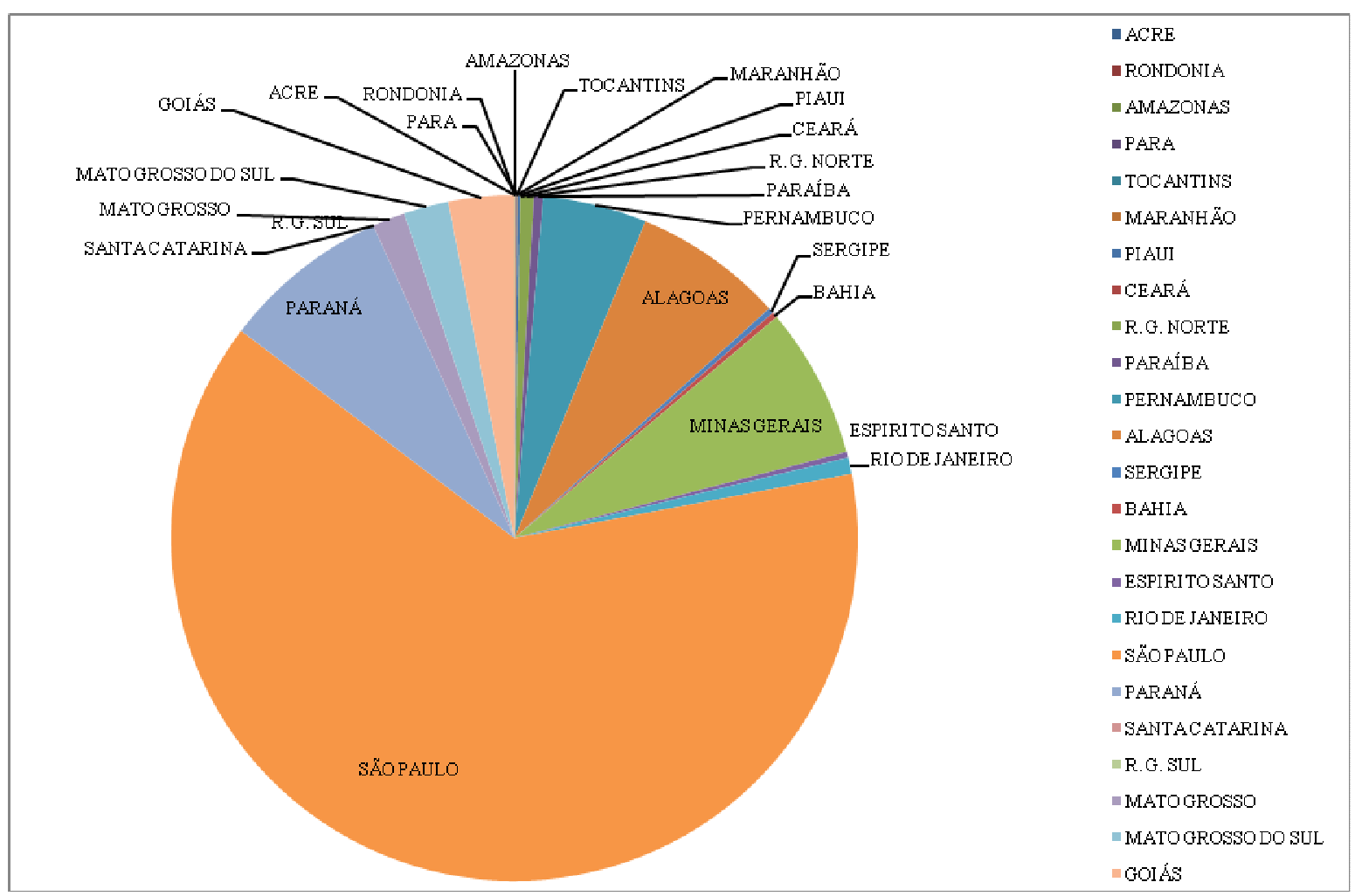

Gráfico 5.2- Produção de cana-de-açúcar por estado - safra 2008/09

Fonte: ÚNICA (2010b) 
Deste volume total de produção, 66,07\% da produção é de etanol hidratado (utilizado como combustível diretamente nos motores a álcool ou flexfuel), com um volume de cerca de 18,85 bilhões de litros produzidos só na safra 08/09.

O Estado de São Paulo apresentou o maior crescimento entre os Estados do período de 1990/91 para 2008/09 com 215,3\% de aumento na produção de etanol, se posicionando também como o maior produtor deste produto, respondendo por $61 \%$ do etanol produzido no país (ÚNICA, 2010c).

Este grande volume de produção se reflete também na área cultivada.

De acordo com a CONAB (2010) a área total de cana-de-açúcar está estimada em 8.167,5 mil hectares para 2010, sendo o Estado de São Paulo o maior com 53,60\% da área total (4.377,66 mil hectares), seguido por Minas Gerais com 8,65\% (706,58 mil hectares) e Paraná com 7,51\% (613,67 mil hectares), ficando os outros Estados com 30,24\%.

Considerando sua escala de produção e expansão a atividade sucroalcooleira tem sofrido questionamentos tanto da comunidade internacional quanto nacional acerca de sua sustentabilidade, em especial no que tange o bioetanol enquanto fonte energética sustentável, dados os impactos evidenciados por estudos acerca do mesmo. (SMEETS et al., 2008).

Para melhor posicionar a atividade em termos de escala e evolução a pesquisa apresenta abaixo um quadro geral sobre a atividade no Estado.

\subsection{Atividade sucroalcooleira no estado de São Paulo}

Como apresentado anteriormente, dados estatísticos evidenciam que a produção do etanol no Estado de São Paulo cresceu 215,3\% nas últimas 10 safras, principalmente por motivações econômicas.

Este movimento expansionista do Etanol, juntamente com o crescimento da produção de açúcar e outros subprodutos da cana-de-açúcar, fez com que o volume de cana produzido no estado crescesse $566,45 \%$ no período. (ÚNICA, 2010b)

Ainda que a produtividade média por área tenha sofrido uma elevação considerável, pelos dados apresentados pela Única (2010b) fica evidente que a grande responsável pela elevação na produção não foi o aumento da produtividade das unidades, mas sim a expansão da cultura para outras áreas.

Isto significa que com o aumento da área cultivada com a cana-de-açúcar que, segundo a CONAB (2010), cresceu $173 \%$ apenas nas safras de 2003/04 à 2008/09, a cultura é a que ocupa a maior área, ocupando atualmente 53,6\% da área agricultável de todo o Estado de São Paulo. 
Como é possível observar pelo Gráfico 5.3 a cana-de-açúcar ocupa grande parte do Estado de São Paulo, contudo, um perfil observável desta ocupação é a não uniformidade da mesma, tendo em vista que as regiões de Ribeirão Preto e Franca concentram grande parte das áreas ocupadas pela cana.

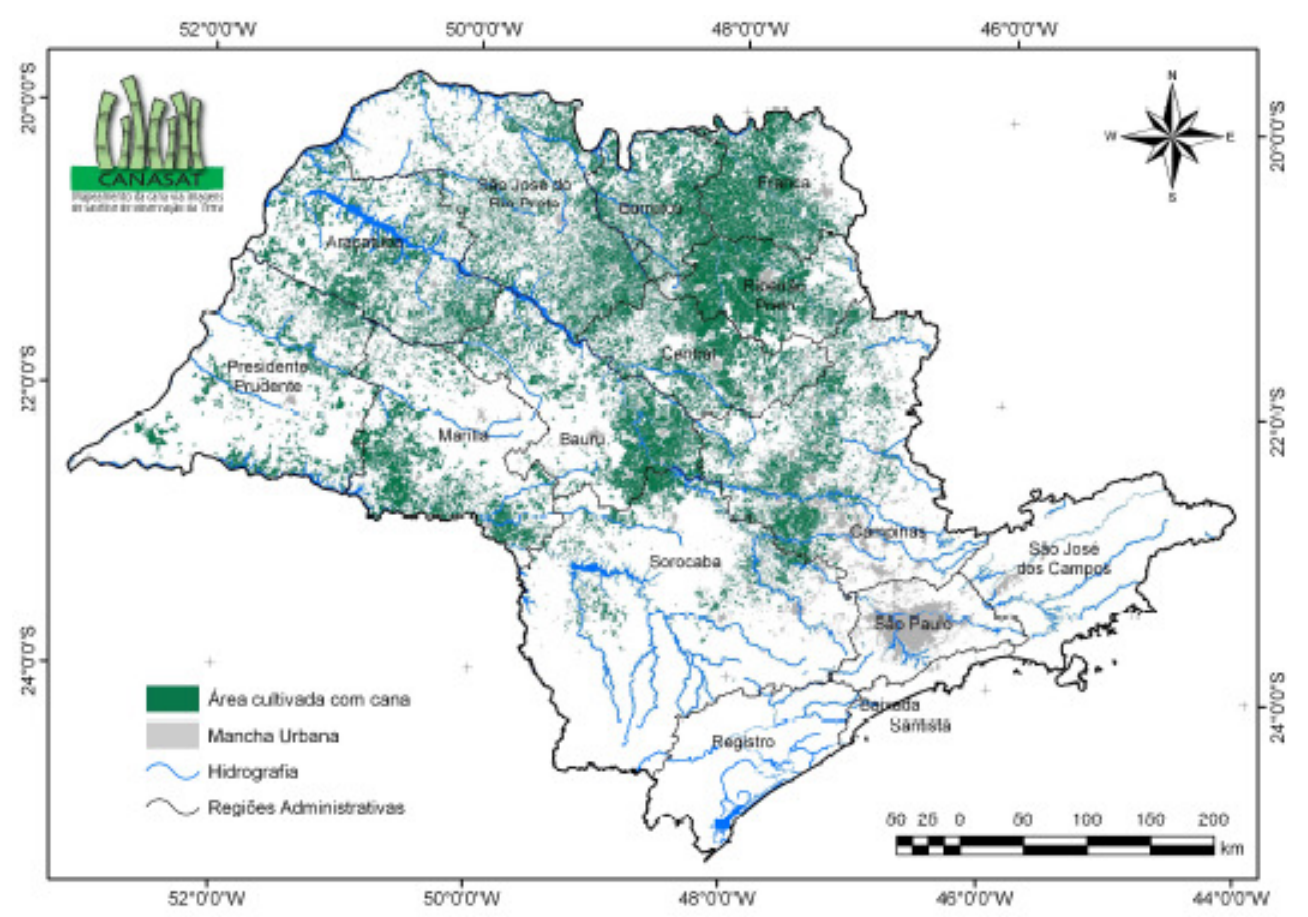

Gráfico 5.3- Ocupação da cana no Estado de São Paulo

Fonte: Rudorff, et al (2009, p. 27)

Segundo Aguiar et al (2009) ainda que exista a maior preponderância da região de Ribeirão Preto esta não é a região onde se observa a maior expansão da atividade. Em grande parte este quadro se deve à saturação da região de Ribeirão Preto e Franca, historicamente grandes produtoras do produto. Tal fato pode ser observado pelo Gráfico 5.4 apresentado a seguir.

A região detentora da maior expansão da atividade nas safras de 2003/04 à 2008/09, segundo Aguiar et al (2009) é a região de Araçatuba, onde o aumento do cultivo da cana-deaçúcar no período foi de cerca de 238,7\%.

Como é possível observar a região de Ribeirão Preto e Franca concentra grande parte da produção de cana-de-açúcar nacional, seguidas das regiões onde a atividade se encontra em ampla expansão.

Para melhor visualização da dinâmica da atividade nos últimos anos Aguiar et al (2009) apresenta um quadro geral por região da expansão da atividade sucroalcooleira nas safras de 2003/04 à 2008/09. 


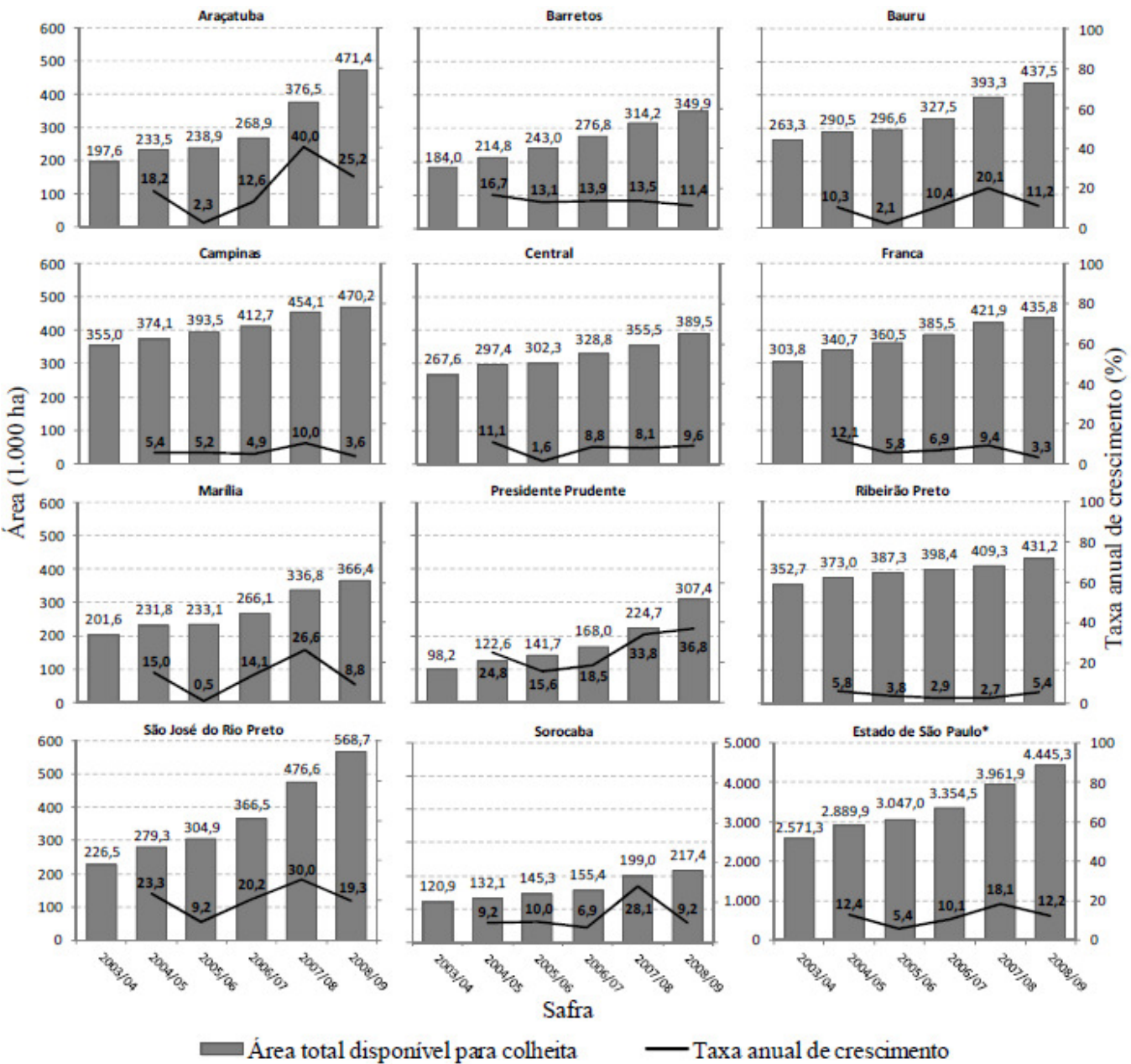

Gráfico 5.4- Evolução da área cultivada e da taxa de crescimento produtivo da cana-de-açúcar por região no estado de São Paulo

Fonte: Aguiar et al (2009, p. 14).

O volume de produção do etanol tem sido sentido em toda a matriz energética nacional. Sua representatividade e principalmente as perspectivas de crescimento futuras são importantes para entendimento e discussão dos cenários futuros da atividade.

Tais questões são abordadas na sessão seguinte que traz a representatividade do etanol na matriz energética nacional e as perspectivas futuras de evolução da matriz em relação a cada fonte energética que a compõe.

\subsection{Etanol e a matriz energética nacional}

A matriz energética nacional demanda atualmente cerca de 243,7 milhões de TEPs Toneladas Equivalentes de Petróleo de acordo com o MME (2010a).

Ainda segundo o MME (2010a) a demanda de energia cresceu 296,83\% nos últimos 36 (trinta e seis) anos no país. Esta dinâmica pode ser observada no Gráfico 5.5. 


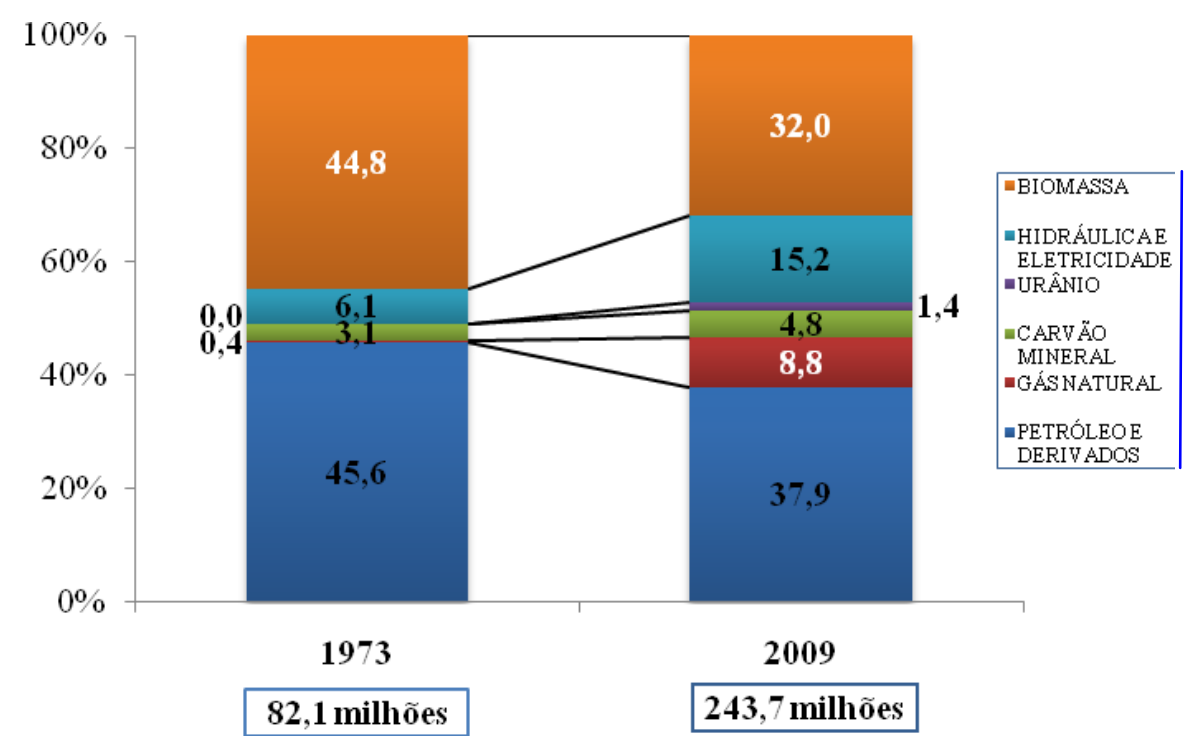

Gráfico 5.5- Matriz Energética Brasileira Fonte: MME (2010a)

Como é possível observar houve um crescimento significativo na demanda energética nacional. Contudo, políticas de diversificação da matriz energética têm feito com que a matriz tenha aumentos de outras fontes energéticas, principalmente da Hidráulica e Elétrica que teve um incremento de $249 \%$ no período e do gás natural, que teve um incremento de $2.200 \%$.

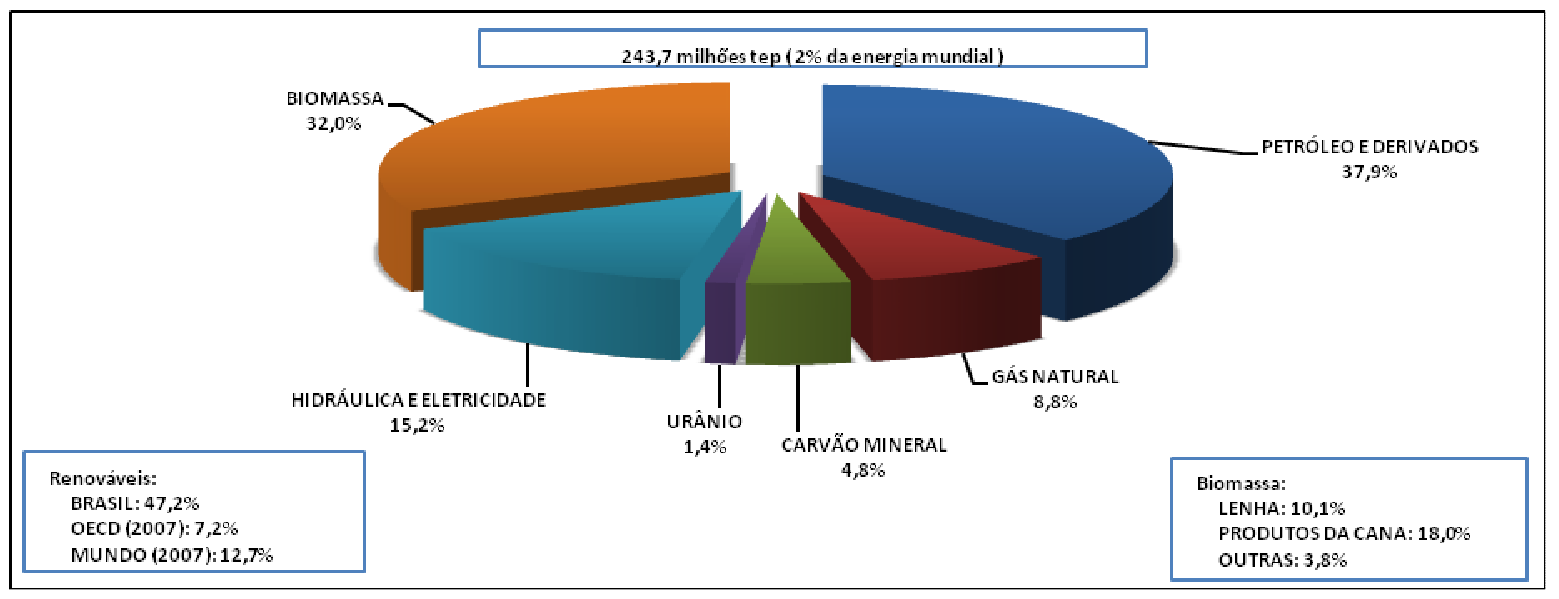

Gráfico 5.6- Matriz Energética Nacional por fonte de Energia Fonte: MME (2010a).

No caso da energia hidráulica e elétrica o incremento se deu pela implementação de novas unidades produtoras, notadamente hidroelétricas, ao longo da malha hídrica nacional, enquanto o incremento no gás natural foi derivado principalmente da construção de dutos (gasodutos) para escoamento da produção de outros países e também pela descoberta de novos reservatórios de gás no Brasil. (MME 2010b) 
O país goza de uma matriz que conta com $47 \%$ de energia proveniente de fontes renováveis, superior à matriz mundial, como se observa pelo Gráfico 5.6.

Como é possível observar a matriz apresenta ainda uma grande preponderância da lenha (com o uso do carvão), mas a cana se mostra a principal fonte da biomassa. Não obstante, sua proporção frente à lenha e ao carvão vegetal vem crescendo vertiginosamente como observa-se pelo Gráfico 5.7.

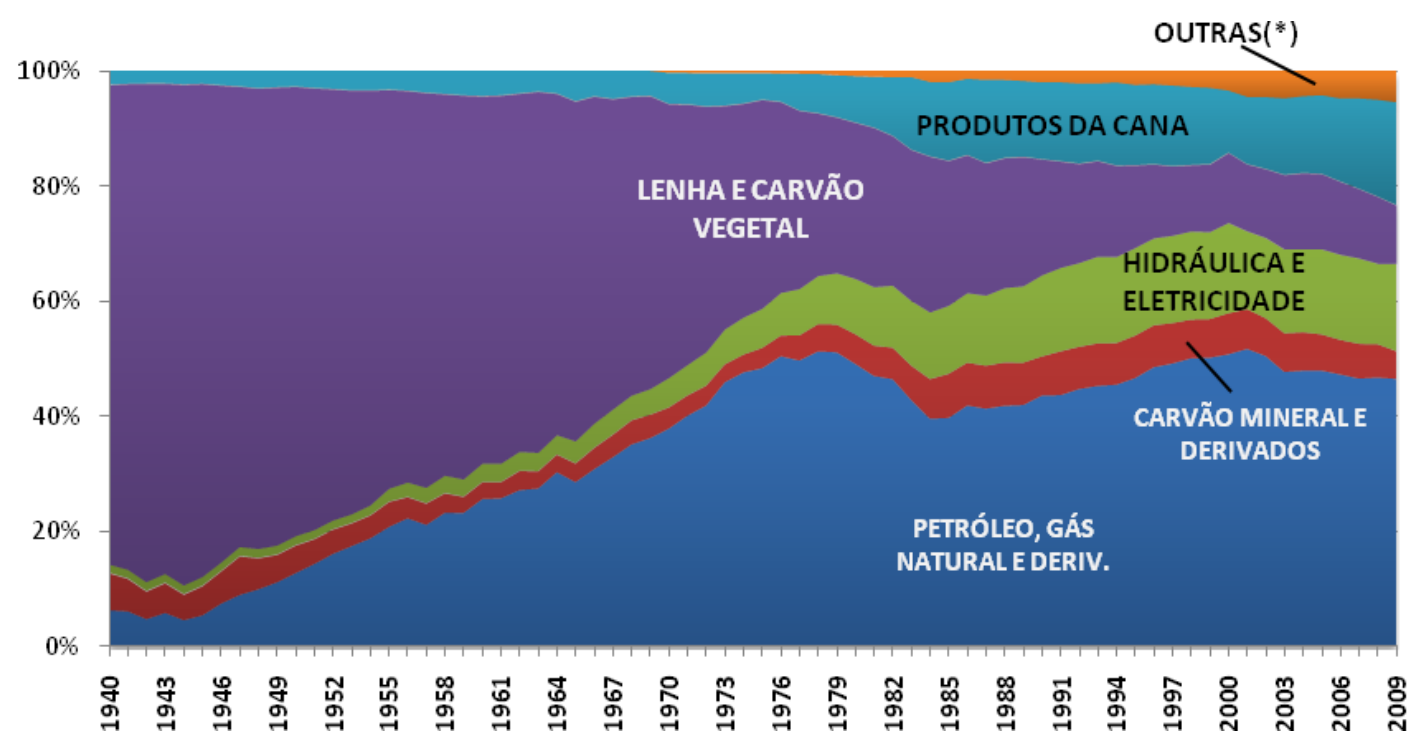

Gráfico 5.7- Evolução da representação da Matriz Energética por fonte no Brasil Fonte: MME (2010b)

No Gráfico 5.7 é possível verificar que a matriz energética nacional vem sofrendo uma alteração na produção e consumo com aumento do uso da energia hidráulica e elétrica, bem como dos produtos da cana e redução principalmente da Lenha e do Carvão Vegetal (provenientes de derrubada de árvores), bem como um cenário de controle e mesmo proporcional redução do uso de produtos derivados do petróleo.

O setor de transportes é um dos maiores consumidores de energia dentro da matriz nacional, sendo que, analisando a evolução histórica observa-se que nos últimos anos o etanol (no Gráfico 5.8 como álcool) tem avançado em representatividade neste setor.

Todo este quadro de elevação na escala produtiva, representatividade no Estado e tendência de evolução, demonstrada no Plano Nacional de Energia (MME, 2010b) apresenta um cenário de crescimento da atividade, o que tem gerado indagações sobre a sustentabilidade do bioetanol como alternativa energética sustentável.

Destaca-se neste sentido a posição de incentivador da atividade que observa-se na política energética nacional, principalmente através da PEN - Plano Energético Nacional, no 
qual está previsto um acréscimo de 395,74\% na produção de etanol em relação à produção atual para o ano de 2030 como expresso pelo MME (2007).

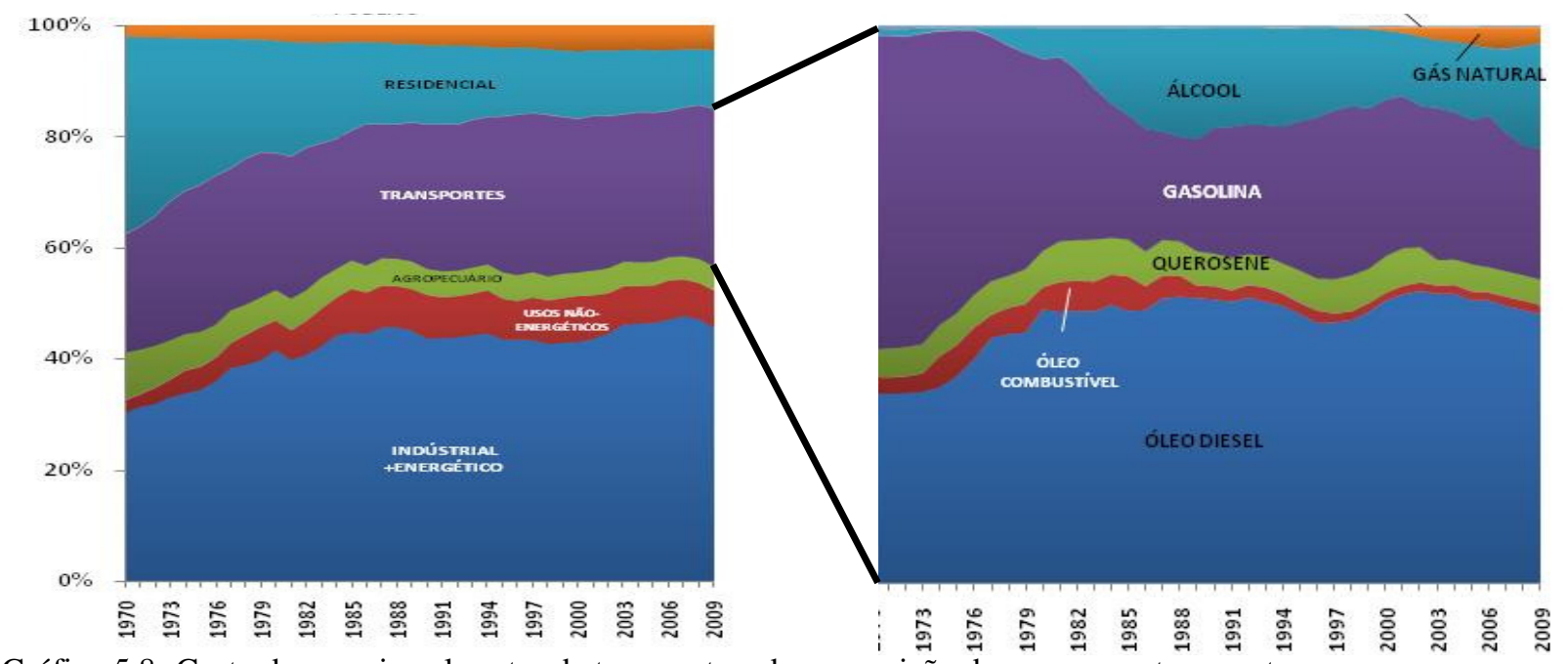

Gráfico 5.8- Gasto de energia pelo setor de transporte e decomposição do uso para o transporte Fonte: (MME, 2010b).

Com esta evolução, as discussões sobre o etanol e a apresentação de diversos estudos sobre os problemas do modelo produtivo do etanol de cana-de-açúcar, em especial abordando os impactos negativos do cultivo e da produção industrial, tem colocado em confronto a viabilidade do produto enquanto fonte sustentável de energia.

Nestes estudos os principais problemas apresentados sobre o modelo de produção estão baseados no uso intensivo do solo e dos recursos naturais, super exploração da mão de obra sujeitando às condições subumanas de trabalho e à ampliação da monocultura. (OMETTO; MANGABEIRA; HOTT, 2005; SMEETS et al., 2008).

Desta forma, dada a escala produtiva, suas tendências e as discussões sobre a sustentabilidade, os mecanismos de gestão e as informações disponíveis devem ser eficientes para dar suporte às tomadas de decisões, capacitando os agentes a discorrerem com mais propriedade sobre o tema e maximizarem o entendimento sobre a sustentabilidade do etanol.

Para que a tomada de decisão seja realizada em bases sólidas as informações devem ser pertinentes, o que significa que os impactos da atividade sucroalcooleira, considerando a esfera ambiental, devem ser conhecidos e mapeados para a composição de informações que permitam propriedade nas discussões e formulações de políticas públicas.

Com vista a este objetivo, a pesquisa apresenta na sessão seguinte um estudo baseado em revisões da literatura sobre os impactos ambientais provenientes da atividade sucroenergética, buscando fornecer bases para a discussão da composição de informações ambientais eficientes para a tomada de decisão. 


\subsection{Impactos ambientais negativos da atividade sucroalcooleira}

O conceito de "impacto ambiental" é encontrado de diversas formas na literatura. A Resolução nº 01/86 do Conselho Nacional do Meio Ambiente (CONAMA), de 23/01/86 $\left(\operatorname{artigo} 1^{\circ}\right)$, define impacto ambiental como:

“Art. $1^{\circ}$ (...) qualquer alteração das propriedades físicas, químicas e biológicas do meio ambiente (...) resultante das atividades humanas que, direta ou indiretamente afete: a saúde, a segurança e o bem-estar da população; as atividades sociais e econômicas; a biota; as condições sanitárias e estéticas do meio ambiente; e a qualidade dos recursos ambientais" (BRASIL, 1986).

Outros conceitos corroboram com esta definição, tais como o apresentado pelo Environmental Protection Agency (EPA, 2010) que define impacto ambiental com o efeito de uma atividade ou substância no meio ambiente.

Adicionalmente, a ISO (2004 apud SÁNCHEZ, 2008, p. 29) define impacto ambiental como “[...] qualquer modificação do meio ambiente, adversa ou benéfica, que resulte, no todo ou em parte, das atividades, produtos ou serviços de uma organização".

Apesar das diferenças, existe concordância entre distintos conceitos no ponto de vista de Sánchez (2008), ao analisar que impacto ambiental é uma consequência de atividades, causas de qualquer modificação ambiental, independentemente de sua importância.

O mesmo autor também expõe a inconveniência de algumas definições ao observar certa semelhança da definição de impacto ambiental com o poluição ambiental, como no caso da Resolução $n^{\circ}$ 01/86 do CONAMA, e explica que a emissão de matéria ou energia (além da capacidade de carga do meio) é o que representa o conceito de poluição, e que esta, causa o impacto ambiental, porém nem todo impacto ambiental tem a poluição como causa.

Isto fica mais evidente quando se entende que "impacto ambiental" não se refere somente a impacto negativo.

De qualquer forma, à luz de todas estas considerações a noção de impacto ambiental que melhor reflete o escopo deste trabalho é o colocado de forma clara por Sánchez (2008), no sentido que impacto ambiental é o resultado (consequência) de uma ação humana (causa), sendo aqui nesta pesquisa com conotação adversa, ou seja, com foco em impactos negativos.

No caso específico da pesquisa estes impactos dizem respeito às atividades de produção e consumo do etanol de cana-de-açúcar no Estado de São Paulo, englobando impactos percebidos nas componentes ambientais água, solo e ar. 


\subsubsection{Qualidade do ar}

Diversos autores (tais como MACEDO et al, 2004; SOARES et al, 2009; KALTSCHMITT; REINHARDT; STELZER, 1997), bem como a mídia e o marketing empresarial colocam o etanol como capaz de reduzir as emissões líquidas de $\mathrm{CO}_{2}$ ao substituir a gasolina, sendo um potencial mitigador da emissão de gases de efeito estufa (GEE).

Esta propriedade benéfica do etanol ainda é discutível, principalmente porque aspectos de sua produção e consumo estão relacionados a outros GEE quando se considera os insumos utilizados na produção, o consumo de combustíveis fósseis tanto pelos maquinários agrícolas quanto para o transporte do produto, as queimadas, o impacto do carbono sequestrado do solo quando comparado com a vegetação nativa substituída, dentre outros.

A maior parte de emissão de GEE ocorre na queima da palha do canavial, na qual há emissão principalmente de metano e óxido nitroso (GARCIA; SPERLING, 2010). Ao se comparar o potencial de efeito-estufa destes gases com o $\mathrm{CO}_{2}$, o IPCC (2006) expõe que uma molécula do gás metano $\left(\mathrm{CH}_{4}\right)$ tem um potencial 21 vezes maior, enquanto que uma molécula de óxido nitroso $\left(\mathrm{N}_{2} \mathrm{O}\right)$ abrange um potencial 310 vezes maior que o $\mathrm{CO}_{2}$.

Sendo a prática da queima utilizada para aumentar a produtividade do trabalho na colheita e reduzir custos de transporte, é preocupante esta situação no Estado de São Paulo, sendo este, responsável por $61 \%$ da produção nacional de etanol (IBGE, 2004). Estimou-se que $40 \%$ da colheita da cana (safra 2008/2009) tenham sido manual (CTC, 2009), o que torna imperativa a prática da queima prévia do canavial.

Neste aspecto, a colheita mecanizada poderia reduzir as emissões, supondo que seja possível introduzí-la no terreno e mesmo assim não poderia desconsiderar que a colheita mecanizada também gera emissões. Ao observar este panorama, outro ponto a ser considerado é a existência dos diferentes cenários tecnológicos, entre grandes e pequenos produtores, que trazem diferenças significativas na quantificação das emissões (SOARES et al, 2009).

Estas peculiaridades se tornam muitas vezes pontos cruciais para o questionamento da sustentabilidade do etanol, sendo a atividade mais sustentável em uma região e menos em outra por estes motivos.

O uso de fertilizantes nitrogenados ou da torta de filtro também apresenta quantidades importantes de emissão de GEE, pois promovem a liberação de $\mathrm{N}_{2} \mathrm{O}$ no solo, agravando o problema se a queima da palha da cana for realizada. (SOARES et al, 2009).

As emissões de $\mathrm{N}_{2} \mathrm{O}$ dos solos ocorrem principalmente em decorrência da desnitrificação do nitrogênio mineral $(\mathrm{N})$, a qual consiste na redução microbiana do nitrato $\left(\mathrm{NO}_{3}\right)$ às formas gasosas $\left(\mathrm{NO}, \mathrm{N}_{2} \mathrm{O}\right.$ e $\left.\mathrm{N}_{2}\right)$ que são perdidas para a atmosfera (CGEE, 2009). 
Portanto, o aumento das adições de fertilizantes nitrogenados sintéticos aos solos agrícolas seria um ótimo indicador das crescentes emissões de $\mathrm{N}_{2} \mathrm{O}$ na atmosfera.

Por outro lado, o problema parece ser menor em relação aos defensivos agrícolas, mas não porque os fatores de emissão de GEE para estes não sejam elevados, e sim porque o consumo de defensivos agrícolas pela cultura da cana é baixo quando comparado a outras culturas, tais como milho (-40\%), café, citros e soja (aproximadamente -90\%). (ÚNICA, 2010a; ARRIGONI, 2005).

No entanto, o aumento pelo consumo pode implicar em um aumento importante no total das emissões, principalmente devido às queimadas que, segundo Cintra, Andrade e Alves (2004) respondem por grande parte das emissões agrícolas mundiais de $\mathrm{CO}_{2}$.

A queima da cana-de-açúcar também provoca outras emissões potencialmente danosas para o meio ambiente e para a saúde humana, tais como materiais particulados, inclusive de partículas menores que 2,5 microns (Material Particulado Fino ou MP 2,5), capazes de atingir nocivamente os pulmões. (CINTRA; ANDRADE; ALVES, 2004)

Os materiais particulados são conhecidos popularmente como fumaça ou fuligem, e ao atingirem os núcleos urbanos causam incômodos a população como poluição visual na atmosfera local, maior consumo de água para limpeza e no caso de partículas muito pequenas, como o caso do MP 2,5, acaba provocando problemas respiratórios sérios.

Não obstante a queima de combustíveis fósseis pelos maquinários agrícolas e pelo transporte do produto (etanol), bem como a queima da biomassa (queimadas), somadas às emissões pelo solo (processos biológicos), resultam direta e indiretamente nas emissões crescentes de óxidos de nitrogênio (NOx), sendo estes grandes influenciadores no aumento das concentrações de ozônio troposférico. (UGUCIONE et al, 2002; CÓNSUL et al, 2004).

Em altas concentrações o ozônio pode afetar a função pulmonar, e em baixas, causar tosse, falta de ar, muco, ardor na garganta, náuseas e até diminuição da função pulmonar quando em casos mais graves. (MALILAY,1999 apud RIBEIRO, 2008.)

No caso da vegetação, o mesmo ocasiona danos às colheitas, plantações agrícolas e plantas ornamentais devido ao seu caráter altamente oxidante, sendo capaz até mesmo de modificar o equilíbrio ambiental de ecossistemas (CETESB, 2008). É bom ressaltar que o ozônio encontrado na faixa de ar próxima do solo, onde respiramos, é tóxico, entretanto, na estratosfera ele tem o papel de "protetor" da Terra contra os raios ultravioletas.

Quando comparado com os combustíveis fósseis o etanol representa um ganho em reduções nos gases de efeito estufa (GEE), tendo em vista a menor emissão destes gases pela queima do etanol (GOMES; ARAÚJO, 2009). 
O uso de etanol em motores flexíveis contribui de certa forma para a melhoria da qualidade do ar nas grandes cidades, uma vez que reduz consideravelmente o nível de emissões prejudiciais advindas do uso de combustíveis fósseis (ver Tabela 5.1).

De acordo com Coelho, Lora e Guardabassi (2010) entre os principais efeitos positivos do uso de etanol (puro ou em mistura com a gasolina) nos centros urbanos destacam-se:

- A eliminação dos compostos de chumbo na gasolina;

- A redução nas emissões de monóxido de carbono;

- A eliminação de enxofre e material particulado; e

- Emissão menos tóxica (aldeídos emitidos pelo uso do etanol são menos tóxicos que os comparados a gasolina).

Tabela 5.1 - Emissões médias dos veículos homologados pelo Proconve $\mathrm{e}^{5}$

\begin{tabular}{lccccc}
\hline \multicolumn{1}{c}{ Combustível utilizado } & $\mathrm{Co}$ & $\mathrm{HC}$ & $\mathrm{NOx}$ & $\mathrm{RCHO}$ & $\mathrm{CO}_{2}$ \\
\hline Gasolina C (22\% de etanol anidro) & 0,33 & 0,08 & 0,08 & 0,002 & 192 \\
\hline Etanol hidratado* & 0,67 & 0,12 & 0,05 & 0,014 & 200 \\
\hline Flex com gasolina C & 0,48 & 0,10 & 0,05 & 0,003 & 185 \\
\hline Flex com àlcool & 0,47 & 0,11 & 0,07 & 0,014 & 177 \\
\hline
\end{tabular}

Emissões medidas em (g/km).

Fonte: Baseado em CETESB (2008).

Contudo, como afirma Gomes e Araújo (2009) existem duas questões fundamentais para serem analisadas quanto à substituição dos combustíveis fósseis pelo biocombustíveis.

O primeiro diz respeito ao balanço energético como um todo, isto é, a necessidade de avaliar as emissões provenientes dos processos produtivos e de consumo do bioetanol em comparação à cadeia dos combustíveis fósseis. De acordo com os autores, esta relação pode ser mais ou menos benéfica em função dos recursos e métodos empregados na produção e consumo do etanol.

Em uma segunda esfera é o aumento exponencial da quantidade de veículos utilizados, fazendo com que sua tecnologia, por menos prejudicial que seja não consiga evitar impactos negativos cumulativos.

Outra ressalva importante é que o bioetanol apresenta uma demanda hídrica bastante significativa, podendo trazer prejuízos acentuados a regiões com disponibilidade hídrica deficiente, ou seja, é possível que se tenha um ganho na esfera atmosférica, mas que este ganho venha associado a uma perda em outro componente ambiental, no caso a dimensão hídrica (GOMES; ARAÚJO, 2009).

5 Proconve é o Programa de Controle da Poluição do Ar por Veículos Automotores que tem o objetivo de reduzir a emissão de poluentes dos veículos automotores, sendo um programa permanente e de responsabilidade da CETESB. 
Ao observar todo este cenário fica evidente a importância em se discutir a qualidade do ar, em especial as queimadas, uma vez que esta tem relação direta tanto na ordem ambiental quanto na econômica e social.

Para isso é necessário que existam leis e políticas eficientes nas diversas esferas, principalmente estadual e municipal, como, por exemplo, a lei n. 11.241 /02 do Estado de São Paulo que dispõe sobre a eliminação gradativa das queimadas, bem como de projetos de lei municipais como em Avaré, Mirandópolis, entre outros que proíbem a queimada no local.

Estas atitudes normativas já são um indicativo que a queima da palha é um problema grave. De qualquer forma devem-se colocar normas e preceitos que prevejam a eliminação da queima e não apenas a regulação da atividade.

Adicionalmente, se mostra essencial o envolvimento voluntário promovido por acordos ou protocolos como forma de maximizar as ações mitigadoras de impactos, considerando que diversas vezes a lei estabelece prazos inadequados à realidade e não garante uma fiscalização eficaz e eficiente de seu cumprimento.

Um exemplo disto é o Protocolo Agroambiental, formado por uma parceria entre a Secretaria de Agricultura e Abastecimento e o setor sucroalcooleiro, no qual estão inseridas diretrizes para a redução da queimada da palha da cana-de-açúcar, da poluição atmosférica, entre outras preocupações ambientais voltadas ao uso do solo e da água, dentro de um horizonte temporal inferior ao estabelecido em lei.

\subsubsection{Qualidade do solo}

Ao se falar dos impactos ambientais referentes ao solo alude-se principalmente a descaracterização do ambiente natural a partir da remoção da vegetação primitiva e práticas incorretas de uso e preservação do solo. Estas ações levam a efeitos maléficos como erosão e/ ou compactação do solo, saturação e/ou toxicidade por agrotóxicos tanto in loco como em corpos hídricos, e consequentemente desencadeiam uma enorme quantidade de impactos.

A compactação do solo é decorrente da mecanização da agricultura, deslocando equipamentos e veículos sobre solos estruturados, o que resulta em sua deformação e compactação. O problema é pior ao se considerar que as operações posteriores de preparo e cultivo da terra demandarão novos investimentos, maquinário e combustível para descompactação deste solo, o que ainda causa fragilidade econômica; bem como emissão de poluentes atmosféricos (ver sessão 5.4.1- Qualidade do Ar).

Solos compactados geram certas modificações ambientais de muita importância agronômica como: aumento da resistência mecânica à penetração radicular, dimuição da 
aeração, modificação do fluxo e da disponibilidade de água e nutrientes (MATOS, 1997; GABRIEL FILHO, 1993).

O processo erosivo é a maior causa da degradação das terras agrícolas, entretanto é relativamente pequena a perda de solo por erosão gerado pela cultura da cana no Brasil. Na Tabela 5.2 é demonstrada uma comparação da cana com outras culturas.

Tabela 5.2- Perdas de solo em culturas anuais e semi-perenes

\begin{tabular}{cc}
\hline Cultura Anual & Perdas de Solo (t/ha.ano) \\
\hline Mamona & 41,5 \\
Feijão & 38,1 \\
Mandioca & 33,9 \\
Amendoim & 26,7 \\
Arroz & 25,1 \\
Soja & 20,1 \\
Batata & 18,4 \\
Cana-de-açúcar & 12,4 \\
\hline
\end{tabular}

Fonte: Adaptado de Donzelli (2005).

A erosão é causada pela alteração estrutural do solo, e no caso da cana esta alteração é provocada principalmente pela prática da queima, a qual reduz a água do solo por meio do calor intenso. Assim, nutrientes e solo são perdidos por carregamento ou enxurradas, o que compromete não só a qualidade daquele solo, mas também pode ocasionar o assoreamento de mananciais (MARTINS FILHO et al, 2009).

Em relação à erosão, Martins Filho et al (2009) colocam seus efeitos no solo, como:

- Perdas de nutrientes e matéria orgânica;

- Perdas de solo muito além dos níveis toleráveis;

- Alterações na textura, estrutura; e

- Quedas nas taxas de infiltração e retenção de água.

Adicionalmente, observam-se outros problemas causados pela erosão, tais como a contaminação e até mesmo assoreamento dos corpos d'água provocados pelo carregamento de partículas contaminantes (agroquímicos) e de solo, bem como a lixiviação de fertilizantes que contamina os solos e os corpos d'água ou áreas de recarga ${ }^{6}$.

A partir deste quadro percebe-se um círculo vicioso, já que os nutrientes são carregados por escoamento erosivo se torna necessário a compensação das perdas de nutrientes, sendo feito pela reposição de fertilizantes industriais no solo. Para mitigar estes impactos Martins Filho et al (2009) indicam que a utilização de tecnologias de cultivo e

\footnotetext{
${ }^{6}$ Estes problemas serão mais bem tratados no tópico a seguir sobre qualidade dos recursos hídricos.
} 
colheita são importantes, uma vez que permitem a realização da colheita sem utilização da queimada em algumas áreas.

Mesmo que a cultura da cana não propicie valores de perda de solo significativos, é importante que o processo de mecanização seja adequado para determinado local, considerando o tipo de solo, a condição climática, entre outros, para que não ocasione solos compactados, e por sua vez, a erosão e toda a cadeia de impactos já mencionados.

Outras tecnologias como a utilização de plantio direto (manejo do solo onde a palha e os restos vegetais são deixados na superfície para cobertura do solo) são capazes de potencializar a mitigação destes impactos, melhorando sensivelmente o nível de conservação dos solos (DONZELLI, 2005). Entende-se por conservação do solo a manutenção e melhoramento de sua capacidade produtiva (Lei Estadual n 6.171, de 04 de julho de 1988, que dispõe sobre o uso, conservação e preservação do solo agrícola).

Torna-se perceptível que o componente ecológico "solo" possui grande significância dentre os outros componentes analisados nesta pesquisa (água e ar), uma vez que o solo possui interfaces de envolvimento direto com tais componentes.

Por fim, apresenta-se na sessão seguinte a qualidade dos recursos hídricos (“água”), complementando os componentes ambientais observados pela presente pesquisa.

\subsubsection{Qualidade dos Recursos Hídricos}

Os impactos nos recursos hídricos possuem ligações diretas e/ou indiretas com o tipo de manejo do solo. Por tal motivo, nesta sessão serão abordados problemas evidenciados no componente ambiental solo além dos recursos hídricos.

Numa primeira análise observam-se os efeitos do uso fertilizantes minerais e orgânicos na produção da cana-de-açúcar, a matéria-prima do etanol. De fato o impacto dos fertilizantes na qualidade dos recursos hídricos depende da condição de uso e taxa de aplicação do produto, além do tipo de solo.

Neste cenário, os componentes principais dos fertilizantes (nitrogênio, fósforo e potássio) podem ser encontrados na água subterrânea, resultado das altas taxas de lixiviação, principalmente em solos submetidos ao plantio contínuo (OLIVEIRA, et al, 2002).

É importante expor a maior vulnerabilidade de solos arenosos com lençol freático raso, que na adubação com nitrogênio, podem sofrer contaminação por nitratos. $\mathrm{O}$ nitrato (NO3-), produto final de uma das reações do nitrogênio (a nitrificação), é um composto químico altamente resistente, passível de contaminar as águas subterrâneas por lixiviação e a atmosfera através do processo de desnitrificação (PIERZYNSKI; SIMS; VANCE, 2000). 
Este componente também é prejudicial à saúde humana, já que a sua ingestão é associada ao risco de enfermidades como a metemoglobinemia (síndrome do bebê azul) e ao câncer gástrico (MANASSARAM; BACKER; MOLLD, 2007).

O fósforo é transportado pelo escoamento superficial para águas superficiais e embora não apresente risco direto para a saúde humana é altamente prejudicial ao meio ambiente por provocar eutrofização de rios e lagos, já que este nutriente favorece a proliferação de algas no corpo d'água com implicações diretas para outros parâmetros de qualidade de água, como por exemplo, aumento da DBO e diminuição do oxigênio (MARTINS FILHO et al, 2009).

Sobre os efeitos do potássio é importante considerar que o amplo uso da fertirrigação possibilita a saturação do solo por sais, o que consequentemente, provoca riscos de contaminação das águas subterrâneas.

A vantagem ambiental no uso destes fertilizantes é a redução da necessidade de novas áreas pelos ganhos de produtividade e, portanto, redução do efeito de supressão de mata nativa. No entanto os danos são graves, pois estão associados aos riscos de contaminação do solo e, deste modo, dos corpos d'água.

Quanto a cana-de-açúcar, a intensidade do uso de fertilizantes ocupa o quarto lugar em comparação a 10 culturas com área acima de 1 milhão de hectares (Tabela 5.3).

Do ponto de vista ambiental, o uso controlado do vinhoto e da torta de filtro como fertilizante é uma boa prática na cultura da cana, pois segundo a CGEE (2009):

- Permite a total reciclagem dos resíduos industriais: vinhoto, torta de filtro e água de lavagem, limpeza do chão, purga do circuito fechado e condensados remanescentes;

- Aumenta a fertilidade do solo;

- Reduz da captação de água para irrigação;

- Reduz o uso de fertilizantes químicos; e

- Reduz os custos.

Ao se considerar a substituição de fertilizantes comercializados por vinhoto e torta de filtro é possível reduzir consideravelmente a quantidade destes primeiros, todavia, inicia então a preocupação com a utilização inadequada da fertirrigação ${ }^{7}$, isto porque a aplicação desses elementos como fertilizantes também pode ocasionar a salinização dos lençóis freáticos pela lixiviação de nutrientes, como também a nitrificação do solo e contaminação dos lençóis freáticos (VEIGA FILHO, 2007).

\footnotetext{
${ }^{7}$ Fertirrigação é uma aplicação combinada de água e nutrientes que no caso da cana-de-açúcar se utiliza do vinhoto.
} 
Tabela 5.3 - Intensidade do uso de fertilizantes por culturas no Brasil

\begin{tabular}{cccc}
\hline Cultura & Área $(1.000 \mathrm{ha})^{2}$ & Consumo $(1.000 \mathrm{t})$ & Consumo/área (t/ha) \\
\hline Algodão & 1.012 & 950 & 0,94 \\
Café $^{1}$ & 2.551 & 1.375 & 0,54 \\
Laranja $^{1}$ & 823 & 406 & 0,49 \\
Cana-de-açúcar $^{1}$ & 5.592 & 2.600 & 0,46 \\
Soja & 21.069 & 8.428 & 0,40 \\
Milho & 13.043 & 4.082 & 0,31 \\
Trigo & 2.489 & 742 & 0,30 \\
Arroz & 3.575 & 872 & 0,24 \\
Feijão & 4.223 & 650 & 0,15 \\
Reflorestamento & 1.150 & 129 & 0,11 \\
\hline
\end{tabular}

${ }^{\mathrm{T}}$ Essas culturas têm o plantio e colheita no próprio ano.

${ }^{2}$ Dados do Levantamento Sistemático da Produção Agrícola, LSPA, IBGE e CONAB.

Fonte: Donzelli (2005) - dados referentes a 2003.

Para Souza (2005) a salinização somente seria problema para o solo se a fertirrigação ultrapassasse a quantidade de $300 \mathrm{~m} 3 / \mathrm{ha}^{8}$, sendo que neste caso afetaria inclusive a qualidade e produtividade da cultura. Isto mostra a inviabilidade do uso irracional da fertirrigação.

Segundo Macedo et al. (2004), a substituição de 30\% de fertilizantes por fertirrigação induz uma redução de $100 \mathrm{~kg} /$ ha na aplicação de fertilizantes como mostra a Tabela 5.4.

Como apresenta a CGEE (2009) o vinhoto é o efluente líquido com a maior carga poluidora da indústria sucroalcooleira, sendo que a quantidade despejada pelas destilarias varia de 10 a 18 litros por litro de bioetanol produzido, variando em função das condições tecnológicas empregadas pela indústria.

Tabela 5.4- Taxa de aplicação de fertilizantes

Taxa (Kg/ ha)

Macro-Nutriente

Cana Plantada

Cana Soca

\begin{tabular}{lcccc} 
& Situação 1 & Situação 2 & Situação 1 & Situação 2 \\
\hline Nitrogênio & 30 & - & 80 & 90 \\
Fósforo & 120 & 50 & 25 & - \\
Potássio & 120 & 80 & 120 & - \\
\hline
\end{tabular}

Fonte: Macedo et al. (2004).

No Estado de São Paulo, a dose de vinhoto aplicada por fertirrigação é regulamentada pela portaria P4231 da Companhia Ambiental do Estado de São Paulo (CETESB), estando condicionada ao seu teor de potássio e à análise química do solo (ROSSETO; SANTIAGO, 2010).

Para o bom emprego do vinhoto Souza (2005) coloca que é importante respeitar as características do solo onde é aplicada e a localização das nascentes d'água, explicando

\footnotetext{
${ }^{8}$ Baseado em estudos feitos em três tipos de solos (aluvial, $51 \%$ de argila; podzólico vermelho amarelo, $38 \%$ de argila; e hidromórfico, 5,5\% de argila)
} 
adicionalmente que resultados de testes indicam que não há impactos nocivos ao solo quando há utilização da vinhaça com doses inferiores a $300 \mathrm{~m}^{3} /$ ha.

O mesmo autor aponta que, no caso do vinhoto, pelas avaliações dos riscos em cinco anos (ciclo) conclui-se que existem metais presentes, mas em teores muito baixos, não representando perigo para o meio ambiente. Em relação aos macro e microelementos minerais, os que apresentam maior concentração nos lixiviados seriam o $\mathrm{K}^{+}, \mathrm{Ca}^{2+}, \mathrm{SO}_{4}{ }^{2-} \mathrm{e} \mathrm{Cl}^{-}$.

Os problemas do vinhoto identificados como potenciais são observados pelo seu poder como poluente que é cerca de cem vezes maior que do esgoto doméstico, decorrente da sua riqueza em matéria orgânica, baixo $\mathrm{PH}$ e por causa dos altos índices de demanda bioquímica de oxigênio - DBO (20.000 a 35.000 mg/l) (SILVA; GOMES; ALSINA., 2007).

Como estabelecem Canellas et al (2007), devido ao fato do PH influenciar na solubilidade dos nutrientes é necessário fornecer artificialmente os nutrientes em falta, mediante uma adubação adequada e correção do PH do terreno.

Tabela 5.5- Composição físico-química da vinhaça

\begin{tabular}{ccccc}
\hline Parâmetro & Unidade & Mínimo & Média & Máximo \\
\hline pH & - & 3,50 & 4,15 & 4,90 \\
Temperatura & ${ }^{\circ} \mathrm{C}$ & 65 & 89 & 111 \\
Demanda Bioquímica de Oxigênio & $\mathrm{mg} / \mathrm{L}$ & 6680 & 16950 & 75330 \\
Demanda Química de Oxigênio & $\mathrm{mg} / \mathrm{L}$ & 9200 & 28450 & 97400 \\
Nitrogênio & $\mathrm{mg} / \mathrm{L}$ & 90 & 357 & 885 \\
Nitrogênio amoniacal & $\mathrm{mg} / \mathrm{L}$ & 1 & 11 & 65 \\
Fósforo Total & $\mathrm{mg} / \mathrm{L}$ & 18 & 60 & 188 \\
Potássio Total & $\mathrm{mg} / \mathrm{L}$ & 814 & 2035 & 3852 \\
Cálcio & $\mathrm{mg} / \mathrm{L}$ & 71 & 515 & 1096 \\
Magnésio & $\mathrm{mg} / \mathrm{L}$ & 97 & 226 & 456 \\
Manganês & $\mathrm{mg} / \mathrm{L}$ & 1 & 5 & 12 \\
Ferro & $\mathrm{mg} / \mathrm{L}$ & 2 & 25 & 200 \\
Sódio & $\mathrm{mg} / \mathrm{L}$ & 8 & 52 & 220 \\
Cloreto & $\mathrm{mg} / \mathrm{L}$ & 480 & 1219 & 2300 \\
Sulfato & $\mathrm{mg} / \mathrm{L}$ & 790 & 1538 & 2800 \\
Sulfito & $\mathrm{mg} / \mathrm{L}$ & 5 & 36 & 153 \\
Etanol - CG & $\% \mathrm{v} / \mathrm{v}$ & 0,01 & 0.09 & 1.19 \\
Levedura & $\% \mathrm{v} / \mathrm{v}$ & 0,38 & 1,35 & 5,00 \\
Glicerol & $\% \mathrm{v} / \mathrm{v}$ & 0,26 & 0.59 & 2.5 \\
\hline
\end{tabular}

Fonte: Elia Neto, Nakahodo (1995).

Como é possível observar pela Tabela 5.5 a variabilidade dos valores é bastante acentuada, o que indica que os manejos e tecnologias aplicados, bem como as características do ambiente são deteminantes para um maior ou menor impacto da vinhaça. 
Sobre a torta de filtro Rosseto e Santiago (2010) esclarecem que esta apresenta alto teor de matéria orgânica, fósforo, cálcio, magnésio, nitrogênio e umidade, podendo até substituir totalmente a adubação fosfatada (ver Tabela 5.6).

Embora o vinhoto e a torta de filtro sejam subprodutos orgânicos, não se pode dizer que apenas a substituição de fertilizantes por vinhoto e torta de filtro traria menores impactos ambientais, uma vez que seu emprego inadequado também apresentaria problemas de contaminação do solo e dos recursos hídricos.

Portanto, para que este ponto não se torne apenas uma vantagem econômica decorrente da viabilidade da utilização destes resíduos como insumos na produção, o monitoramento e fiscalização desta prática devem ser feitos, pois estas são medidas essências para garantir a sustentabilidade.

É importante construir oportunidades para garantir a prática do uso do vinhoto nos canaviais, como induzir conhecimento em relação às qualidades do vinhoto e sua utilização para os usineiros, além de um correto plano de manejo.

Tabela 5.6- Composição química aproximada de 100 gramas de torta de filtro.

\begin{tabular}{cc}
\hline Parâmetro & Quantidade \\
\hline Carbono & $8,04 \%$ \\
Nitrogênio & $0,28 \%$ \\
Fósforo Orgânico & $0,53 \mathrm{mg}$ \\
Fósforo Inorgânico & $1,18 \mathrm{mg}$ \\
Fósforo Total & $1,70 \mathrm{mg}$ \\
Potássio & $56.64 \mathrm{mg}$ \\
Carbono & $0,80 \mathrm{~g}$ \\
Magnésio & $76,9 \mathrm{mg}$ \\
Matéria Orgânica & $16,90 \%$ \\
Água livre & $77,77 \%$ \\
Boro & $3 \mathrm{ppm}$ \\
Cobre & $11-15 \mathrm{ppm}$ \\
Manganês & $138-196 \mathrm{ppm}$ \\
Zinco & $20-33 \mathrm{ppm}$ \\
Cobalto & $0,3 \mathrm{ppm}$ \\
Ferro & $3.500 \mathrm{ppm}$ \\
\hline
\end{tabular}

Fonte: Vitti et al. (2006 apud ROSSETO; SANTIAGO, 2010).

Uma alternativa para isto é o emprego da Norma técnica P 4.231/2005 da CETESB/SMA (que regulamenta a aplicação do vinhoto no Estado de São Paulo) para outros Estados e até mesmo para nível nacional, com as adaptações necessárias.

Existe ainda a problemática dos defensivos agrícolas inseticidas, herbicidas, fungicidas. Estas substâncias são tóxicas, sendo que, quando usadas de forma indevida, 
acabam sendo levadas para os rios pelas chuvas, provocando a contaminação e diminuição da potabilidade da água, trazendo problemas para a biota aquática e para a saúde humana.

A Figura 5.1 a seguir apresenta a quantidade de defensivos agrícolas empregados na produção de cana-de-açúcar.

Segundo Arrigoni (2005) e a Anvisa (2008) o consumo de inseticidas pela cultura da cana é relativamente baixo, sendo que o consumo de fungicidas e acaricidas é praticamente nulo. Ao comparar a cana-de-açúcar com outras lavouras como citros, milho, café e soja, no que tange ao uso de pesticidas, esta apresenta um consumo inferior.

Tal quadro pode ser otimizado pelo emprego de controle biológico para as principais pragas da cultura. Contudo, como expresso por Scorza Júnior (2009) a cultura da cana-deaçúcar ainda assim é responsável por 13\% do consumo de agroquímicos no Brasil, figurandose a quarta maior consumidora de agrotóxicos atualmente.

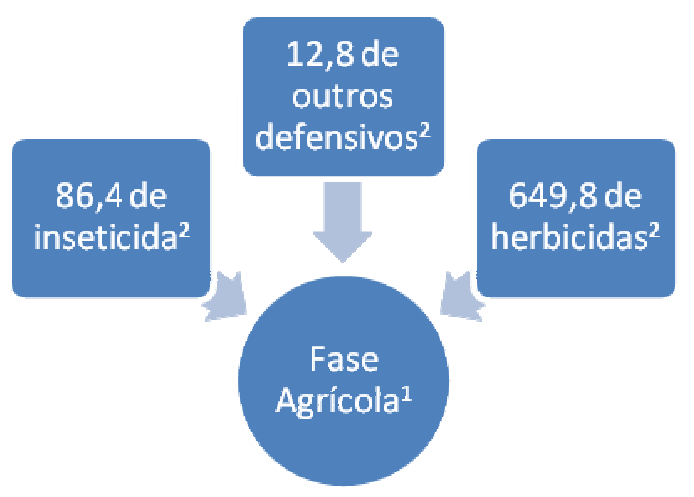

Figura 5.1- Uso de defensivos agrícolas pela cultura de cana-de-açúcar Fonte: Adaptado de Arrigoni (2005).

NOTAS: ${ }^{1}$ Considerando 71 t de cana/ha e 881 de etanol/t de cana.

${ }^{2}\left(\mathrm{mg} / \mathrm{m}^{3}\right.$ etanol).

Observa-se que a visão tratada por Arrigoni (2005) e a Anvisa (2008) se mostra uma visão otimista em relação à cultura, isto é, uma visão para um cenário onde emprega-se diversas tecnologias e manejos para a cultura da cana-de-açúcar, o que não se observa na prática em todas as áreas onde a cultura está presente.

Os herbicidas já são um produto muito utilizado pela cultura de cana, uma vez que plantas daninhas levam a grandes perdas por redução de produtividade, ultrapassando o café e o milho como exemplos para comparação (ARRIGONI, 2005).

Contudo, observam-se dificuldades em discutir estes produtos e seus impactos devido ao elevado número de compostos ativos e a variação da composição nos mesmos, sendo que no mercado encontram-se milhares de produtos diferentes, cada um com suas particularidades 
e consequências negativas. Não obstante estas consequências vão depender também da situação em que são empregados, ou seja, tipo de solo, quantidade da dosagem, outros.

De qualquer modo isto não isenta a necessidade de avaliação para cada caso e do questionamento sobre o quanto a cultura da cana-de-açúcar, isto é, de discutir se a produção do etanol se encontra perto ou distante do desenvolvimento sustentável.

Mas, de todos os problemas apresentados até o momento, o consumo da água pela produção do etanol tem sido o assunto mais preocupante e acentuado nas discussões sobre os componentes ambientais, pois na discussão desta matéria não são encontradas soluções práticas e rentáveis se comparado às outras questões já discutidas.

Na fase agrícola a produção de cana-de-açúcar no Estado de São Paulo é realizada praticamente sem o uso de irrigação (ARRIGONI, 2005), porém na fase industrial sua demanda é preocupante.

Tal quadro pode piorar ainda mais ao considerar o aumento da demanda hídrica devido à expansão canavieira (como exposto na seção anterior - 5.2 sobre a expansão canavieira no Estado de São Paulo) que pode acarretar a exploração de regiões com déficits hídricos mais acentuados. (GOMES; ARAÚJO, 2009)

Esta alta dependência na fase industrial é porque a água captada é usada em vários processos, principalmente para resfriamento de equipamentos e sistemas (Tabela 5.7).

Tabela 5.7- Usos da água (valores médios) em usinas de álcool (destilarias)

\begin{tabular}{cccc}
\hline Setor & Processo & $\begin{array}{c}\text { Uso médio }\left(\mathbf{m}^{\mathbf{3}} / \mathbf{t} \text { de }\right. \\
\text { cana total })\end{array}$ & $\begin{array}{c}\text { Distribuição } \\
(\mathbf{\%})\end{array}$ \\
\hline Alimentação & Lavagem de cana & 5.33 & 25,4 \\
Extração (Moendas) & Embebição & 0,25 & 1,2 \\
& Resfriamento de Mancais & 0,15 & 0,7 \\
Tratamento de Caldo & Preparo de Leite de cal & 0,01 & 0,1 \\
& Embebição de Filtros & 0,04 & 0,2 \\
& Condensadores dos Filtros & 0,30 & 1,4 \\
Concentração do Caldo & Diluição de méis & 0,03 & 0,1 \\
Geração de Energia & Produção de Vapor & 0,50 & 2,4 \\
& Resfriamento tubogeradores & 0,20 & 1,0 \\
Fermentação & Resfriamento do caldo & 1,00 & 4,8 \\
& Resfriamento de dornas & 3,00 & 14,3 \\
Destilaria & Resfriamento de condensadores & 4,00 & 19,0 \\
Outros & Limpeza de pisos e equipamentos & 0,05 & 0,2 \\
& Uso Potável & 0,03 & 0,1 \\
Total & & $\mathbf{2 1 , 0 0}$ & $\mathbf{1 0 0 , 0}$ \\
\hline
\end{tabular}

Fonte: Neto (2005).

Para que as taxas de captação de água possam ser reduzidas significativamente, devese utilizar das formas de reutilização da água como, por exemplo, sua reutilização para 
fertirrigação juntamente com a vinhaça, e/ou substituir a lavagem de cana molhada por lavagem seca (CGEE, 2009; THE WORLD BANK, 1997; SMEETS et al. 2008).

Sabendo que o problema se agrava muito mais ao considerar a expansão da cana, é perceptível que toda esta ampliação agrícola-produtiva não se resume somente ao questionamento sobre sua influência do aumento da demanda de água, mas vai além disto.

É de fundamental importância investigação e estudos com intuito de ter conhecimento sobre quais áreas estão sendo incorporadas e quais são as consequências.

Na opinião de Donzelli (2005) a expansão da cana vem ocorrendo pela incorporação de áreas de pastagens (extensivas na maioria) e, neste sentido, auxilia mais do que prejudica. Para o autor tal auxílio é derivado da recuperação destes solos, uma vez que a pecuária é mais nociva ao solo do que a agricultura e que a cultura canavieira possui destaque por realizar tratamento de solo, fertirrigação e ser uma cultura com baixa taxa de erosão.

Todavia, como estabelecem Guimarães, Turetta e Coutinho (2010) estudos têm apresentado que os deslocamentos da pecuária e de culturas menos rentáveis pela expansão da cana podem ocorrer sobre áreas de florestas nativas e de biomas sensíveis como é o caso do Cerrado e a Mata Atlântica no Estado de São Paulo, isto é, mesmo que de modo indireto, a atividade estaria trazendo problemas de ocupação do solo e impactos na biodiversidade.

O quadro de impactos da cultura da cana-de-açúcar nas diversas dimensões ambientais e sua tendência de forte expansão no Brasil forçam a discussões sobre a sustentabilidade da atividade, em especial no que tange o etanol, como estabelecem Guimarães, Turetta e Coutinho (2010).

\subsection{Discussões sobre sustentabilidade para o etanol de cana de açúcar}

Conduzir as atividades rumo à sustentabilidade é uma temática que vem sendo amplamente discutida entre diversos interessados, tais como: empresas, ONGs, estudiosos, políticos, sociedade, dentre outros. Estas discussões ganham contornos divergentes em função das particularidades dos pontos de vista e mesmo dos conceitos sobre sustentabilidade, seja de uma forma genérica ou mesmo em relação à sustentabilidade de uma atividade específica.

Como abordado por Turner (1987) e discutido no capítulo 3, existem diversas visões sobre sustentabilidade relacionando o crescimento econômico e o meio ambiente. Estas visões distintas provocam pontos de vistas igualmente distintos sobre sustentabilidade.

Não obstante, as divergências sobre o conceito de sustentabilidade são provenientes também, de acordo com Tayra (2006), de particularidades nos valores, visões e objetivos dos 
envolvidos, provocando visões e enfoques distintos sobre sustentabilidade, seja global, local ou mesmo sustentabilidade de uma atividade específica.

Contudo, ainda que seja um tema divergente, a busca por um consenso sobre o entendimento de sustentabilidade de uma atividade é algo importante para todos os envolvidos, uma vez que esta discussão avança para uma atuação capaz de garantir a continuidade da atividade sem prejuízos para a sociedade e o meio ambiente.

Ao considerar os biocombustíveis uma das áreas energéticas com maior crescimento nos últimos anos no Brasil, principalmente pela representatividade do etanol de cana-deaçúcar neste cenário (ÚNICA, 2010c), suas perspectivas futuras (MME, 2007), suas relações históricas no que tange os aspectos político-econômico-sociais e os impactos da atividade no meio ambiente (apresentados na sessão 5.4 deste capítulo), discutir o conceito de sustentabilidade do setor é algo de interesse de todos os envolvidos com a atividade.

As partes interessadas na atividade são todos os atores envolvidos de forma direta ou indireta com o ciclo de vida do etanol, desde os envolvidos com a produção e uso de insumos, produção industrial, consumo e os impactados pela cultura.

Diretamente envolvidos podem ser observados os trabalhadores, fornecedores e consumidores relacionados com a atividade, enquanto indiretamente envolvidos são todos os atores afetados de alguma forma pela cadeia do produto, tais como: sociedades locais e globais (afetadas pela produção e uso do produto), produtores locais de outras atividades, consumidores de produtos concorrentes (produção concorrente), dentre outros.

Como abordado por Sachs (2002) a sustentabilidade deve ter suas bases em diferentes dimensões, tais como: social, econômica, ecológica, cultural, ambiental, territorial, política nacional e política internacional.

De acordo com Tayra (2006) as discussões sobre sustentabilidade adotando o pluralismo metodológico e de objetivos tem se mostrado polarizadas para uma orientação mais econômica. Para o presente estudo concentra-se na observação das ações voltadas para a dimensão ambiental, visualizando assim, no âmbito do componente ambiental as principais ações relacionadas à sua sustentabilidade.

Ao analisar o contexto do etanol de cana-de-açúcar a ÚNICA (2010a) indica que o Brasil tem reduções líquidas de GEEs da ordem de 46,6 milhões de toneladas por ano de $\mathrm{CO}_{2}$ pela utilização do etanol nos transportes em detrimento à gasolina.

Este cálculo leva em consideração a captação de $\mathrm{CO}_{2}$ pela produção agrícola da cana, as emissões da produção industrial e logística e as emissões derivadas da queima do etanol nos meios de transportes. 
Não obstante a reutilização de rejeitos sólidos da produção como a cogeração de energia elétrica pelo bagaço e disponibilização de excedentes produtivos para o sistema energético nacional, bem como reutilização de rejeitos líquidos através do manejo da água e da fertirrigação são também exemplos de minimização de impactos ambientais pela atividade.

Tais características fizeram com que o etanol ganhasse notoriedade na busca por práticas sustentáveis em energia.

Todavia, estudos demonstram diversos impactos provenientes da produção e uso do etanol, sendo o controle e monitoramento destes impactos dependente de tecnologia, conscientização, regulamentação e fiscalização, pairando dúvidas sobre a capacidade do mesmo em se configurar como uma solução viável para a condução da sustentabilidade na matriz energética.

Em inúmeras formas, a preocupação com a sustentabilidade da atividade tem feito com que ações sejam tomadas em esferas locais, regionais e globais frente à sustentabilidade dos biocombustíveis, principalmente através da produção de critérios e certificações para a sustentabilidade. Tais questões estão discutidas nos âmbitos internacional e nacional nas sessões seguintes.

\subsection{Sustentabilidade para o etanol no contexto internacional}

As discussões sobre sustentabilidade no âmbito mundial vêm sendo conduzidas principalmente por meio de agências e órgãos de fomento e centros de pesquisa voltados para a formulação, divulgação e utilização de critérios, guias e indicadores de sustentabilidade como é possível observar no Quadro 5.1.

\begin{tabular}{|c|c|c|}
\hline Instituições & Contribuição & Endereço eletrônico \\
\hline $\begin{array}{l}\text { Nações Unidas (CSD, } \\
\text { PNUMA, CEPAL, outros) }\end{array}$ & $\begin{array}{l}\text { Critérios de Sustentabilidade nos } \\
\text { aspectos social, ambiental e } \\
\text { econômico }\end{array}$ & http://www.un.org \\
\hline $\begin{array}{l}\text { WWF (Fundo Mundial para a } \\
\text { Vida Selvagem) }\end{array}$ & $\begin{array}{l}\text { Apóiam a Sustentabilidade } \\
\text { Ecológica }\end{array}$ & http://www.wwf.org \\
\hline $\begin{array}{l}\text { IISD (Instituto Internacional } \\
\text { para o Desenvolvimento } \\
\text { Sustentável) }\end{array}$ & $\begin{array}{l}\text { Indicadores para desenvolvimento } \\
\text { sustentável }\end{array}$ & http://www.iisd.org \\
\hline $\begin{array}{l}\text { OECD (Organização para a } \\
\text { Cooperação Econômica e } \\
\text { Desenvolvimento) }\end{array}$ & $\begin{array}{l}\text { Indicadores para desenvolvimento } \\
\text { sustentável e Indicadores } \\
\text { Agroecológicos }\end{array}$ & http://www.oecd.org \\
\hline $\begin{array}{l}\text { The World Bank (Banco } \\
\text { Mundial) }\end{array}$ & $\begin{array}{l}\text { Indicadores ambientais e de } \\
\text { desenvolvimento sustentável }\end{array}$ & http://www.worldbank.org/ \\
\hline
\end{tabular}

Quadro 5.1- Exemplos de Instituições mundiais e suas contribuições para a sustentabilidade

Fonte: Elaborado pela autora 
O grande número de instituições, bem como suas contribuições para o tema e sua acessibilidade demonstra a preocupação comum destes agentes com a questão da sustentabilidade.

O setor de energia é um dos setores de destaque no que tange a sustentabilidade, dados os impactos provenientes da produção e uso das fontes energéticas disponíveis e utilizadas em larga escala atualmente. Como expresso por Goldemberg e Lucon (2008) o etanol desponta como um possível candidato para conduzir a matriz energética rumo à sustentabilidade.

Contudo, a produção e uso deste produto apresentam também impactos que desafiam sua viabilidade como fonte energética sustentável. A preocupação com os impactos negativos da produção e uso do etanol faz com que diversos atores busquem produzir critérios e certificações de sustentabilidade que possam guiar o produto para a sustentabilidade.

Em especial observa-se que têm sido formulados sistemas de certificação de sustentabilidade bioenergética, sendo estes sistemas, em grande parte, provenientes de procedimentos para a conformidade de qualidade relacionada a padrões de sustentabilidade. (LEWANDOWSKI; FAAIJ, 2006).

De uma forma geral, observa-se que os esforços para a garantia de sustentabilidade da atividade bioenergética vêm sendo constituídos sob a forma de sistemas de certificação, que, como expresso por Delzeit e Holm-Müller (2008), são formas de conformidade no atendimento a normas e padrões pré-estabelecidos para a produção e uso dos produtos.

A justificativa para o aumento das preocupações com sistemas de certificação de bioenergia, segundo Lewandowski e Faaij (2006), está relacionada ao aumento da comercialização destes produtos e suas tendências futuras, principalmente direcionadas por melhorias nos quadros relacionados aos custos de importação e a melhoria nas garantias logísticas e de suprimentos destes produtos.

Ainda segundo os autores estes sistemas de certificação estão pautados em critérios ou guias para gestão de aspectos ambientais e sociais relacionados com o processo devendo, tais critérios e guias, contemplarem todos os stakeholders relacionados com a produção e comercialização (nacional e internacionalmente).

Neste contexto existem diversos critérios econômicos, sociais, ambientais, etc. que estão sendo desenvolvidos como critérios para a sustentabilidade da bioenergia. Estes critérios compõem os sistemas de certificação, que estão baseados principalmente em indicadores, utilizados como fontes para tornar mensuráveis e verificáveis os aspectos observados.

Lewandowski e Faaij (2006) apresentam um quadro (Quadro 5.2) que aponta os stakeholders envolvidos com a produção e comercialização de bioenergia. 


\begin{tabular}{|c|c|}
\hline Stakeholders & Interesse na certificação \\
\hline Indústria e comercio & $\begin{array}{l}\text { Instrumento para marketing ambiental e acesso a mercados; Ferramenta } \\
\text { para controle da origem e qualidade dos materiais utilizados, produtos ou } \\
\text { serviços. }\end{array}$ \\
\hline Compradores e consumidores & $\begin{array}{l}\text { Fornecimento de informações sobre impactos dos produtos comprados; } \\
\text { Melhoria na confiança nos produtos; Fornecimento de informações se os } \\
\text { produtos atendem os padrões de qualidade ou padrões técnicos; }\end{array}$ \\
\hline Produtores e gestores & $\begin{array}{l}\text { Ferramenta para acesso a mercados ou para ganho de vantagem } \\
\text { mercadológica; Fornece informações para otimização do processo } \\
\text { produtivo; Permite a diferenciação dos produtos }\end{array}$ \\
\hline Governantes & $\begin{array}{l}\text { Instrumento político para promover gestão e padrões de consumo } \\
\text { sustentáveis; Fornece informações para tomada de decisão }\end{array}$ \\
\hline
\end{tabular}

Quadro 5.2 - Interesse dos diversos stakeholders na certificação bioenergética

Fonte: Lewandowski e Faaij (2006, p. 85)

Diversas outras iniciativas são observadas no cenário mundial que tratam da sustentabilidade de biocombustíveis, com destaque para iniciativas como o BSI - Better Sugarcane Initiative (2010) que compõe um conjunto de seis princípios, a saber:

a) Obediência à lei;

b) Respeito aos direitos humanos e às normas trabalhistas;

c) Eficiência em entradas, produção e processos para alcance da sustentabilidade;

d) Gerenciar ativamente a biodiversidade e os serviços dos ecossistemas;

e) Melhoria contínua nas áreas chave do negócio.

Outra iniciativa de destaque no campo da certificação de sustentabilidade é a RSB Roundtable on Sustainable Biofuels (2010).

A RSB é uma iniciativa internacional que incorpora diversos agentes para a concepção de um sistema de certificação que garanta a sustentabilidade da produção e processos de biocombustíveis por meio de um sistema de avaliação de terceira parte $^{9}$ para certificação de padrões de sustentabilidade.

Entretanto, observam-se lacunas no quadro de stakeholders apresentado por Lewandowski e Faaij (2006), em especial em impactos apresentados pelos próprios autores e que é corroborado por Delzeit e Holm-Müller (2008).

Estes autores afirmam que os impactos do setor sucroenergético estão relacionados com a intensificação da monocultura e a pressão desta sobre outras culturas, em especial sobre culturas de gênero alimentício, além de problemas relacionados ao subemprego da mão de obra e ao uso intensivo dos recursos naturais.

\footnotetext{
${ }^{9}$ Sistema de avaliação no qual uma terceira parte independente (órgão ou entidade certificadora não relacionada com o produtor ou com o comprador) avalia a conformidade do ator no atendimento aos requisitos da norma.
} 
Desta forma, observa-se que existem diversos outros interesses não considerados nos processos de criação de sistemas de certificação bioenergética para a sustentabilidade apresentados por Lewandowski e Faaij (2006), caracterizando estas certificações como mecanismos mais relacionados com a prática comercial do que efetivamente com os preceitos da sustentabilidade discutidos no capítulo 3 desta pesquisa e afirmados por autores como Tayra (2006), Sachs (2002), dentre outros, no que tange a participação dos atores envolvidos.

Este posicionamento não contrapõe o posicionamento der Goldemberg e Lucon (2008) sobre os benefícios do bioetanol na condução da matriz energética para a sustentabilidade.

Contudo, observa-se que o posicionamento internacional, em especial relacionado à comercialização, ainda que seja uma iniciativa pró-ativa e que alavanca as discussões sobre sustentabilidade da atividade e trazem a utilização de critérios e indicadores para sua avaliação, não podem ser consideradas ações que, de forma padronizada, são capazes de conduzir a atividade rumo à sustentabilidade.

\subsection{Sustentabilidade para o etanol no contexto brasileiro}

O Brasil é o principal produtor de etanol de cana-de-açúcar do mundo com elevadas perspectivas de crescimento para os próximos anos. Tais perspectivas têm feito com que o setor sucroenergético seja cobrado de respostas eficientes na mitigação dos impactos provocados pela produção e uso de etanol em larga escala.

Dadas estas características e a competitividade real do etanol brasileiro com a gasolina, o país tem se mostrado um dos principais na composição e utilização de biocombustíveis (notadamente o etanol) em seu mercado doméstico, expandindo também suas intenções para o mercado externo por meio de exportações.

Para Goldemberg e Lucon (2008) o etanol brasileiro é dotado de características que o tornam viável para substituição dos derivados de petróleo, principalmente pela capacidade de produção, tecnologia e pelos seus custos competitivos.

Não obstante, Goldemberg e Lucon (2008) expressam que os impactos provenientes da atividade sucroenergética podem ser mitigados por meio de um planejamento consistente para o uso do solo e dos recursos naturais que contemplem a preservação dos ecossistemas, da biodiversidade, dos recursos hídricos, de um adequado manejo de fertilizantes e de controle de pragas, além de um gerenciamento da competitividade entre culturas, em especial sobre terras com alimentos e de populações assentadas.

Estas ações mitigadoras observadas estão principalmente relacionadas com o uso de tecnologia para a produção e emprego de novas variedades de cana, métodos de controle de 
pragas, políticas públicas e regulação ambiental, dentre outros (CGEE, 2009). Diversas instituições estão envolvidas neste sentido, como é observável pelo Quadro 5.3.

\begin{tabular}{cl}
\hline Instituições & \multicolumn{1}{c}{ Ações realizadas } \\
\hline $\begin{array}{c}\text { Universidades } \\
\text { Instituto de Pesq. Tecnológica } \\
\text { (IPT) }\end{array}$ & $\begin{array}{l}\text { Responsáveis pela realização de pesquisas, desenvolvimento e } \\
\text { consolidação do setor sucroalcooleiro no país. }\end{array}$ \\
$\begin{array}{c}\text { Agência Paulista de Tecnologia dos } \\
\text { Agronegócios (APTA) }\end{array}$ & $\begin{array}{l}\text { Realiza estudos socioeconômicos, propõe e analisa políticas } \\
\text { públicas, gera informações e banco de dados que auxiliam o } \\
\text { planejamento e operacionalização econômica do setor. }\end{array}$ \\
\hline $\begin{array}{c}\text { Instituto de Economia Agrícola } \\
\text { (IEA) }\end{array}$ & $\begin{array}{l}\text { Responsável por pesquisas para o desenvolvimento de novas } \\
\text { variedades e melhoramentos genético, fitotécnico, fisiológico, } \\
\text { climatológico, da cana-de-açúcar com aproximadamente 35 } \\
\text { variedades em produção, buscando aumentar os níveis de } \\
\text { produtividade, tolerância à seca, resistentes a pragas e } \\
\text { indicadas à produção de etanol, entre outras. }\end{array}$ \\
\hline $\begin{array}{c}\text { Instituto Agronômico de Campinas } \\
\text { (IAC) }\end{array}$ & $\begin{array}{l}\text { Desenvolve pesquisas relativas às pragas e doenças, prestando } \\
\text { assistência e certificação às usinas quanto ao controle de pragas } \\
\text { e doenças, implantação de biofábricas, além de oferecer cursos } \\
\text { específicos aos interesses do setor. }\end{array}$ \\
\hline Instituto Biológico (IB) & $\begin{array}{l}\text { Desenvolve pesquisas tecnológicas para um grupo de } \\
\text { associados (produtores) nas áreas agrícola, climatológica, } \\
\text { biotecnológica e industrial para a produção de açúcar, etanol e } \\
\text { energia em toda a cadeia de valor da cana-de-açúcar. }\end{array}$ \\
\hline Centro de Tecnologia Canavieira \\
CTC e da Canavialis/ Allelys
\end{tabular}

Quadro 5.3- Instituições e suas ações realizadas para o setor sucroalcooleiro Fonte: CGEE (2009)

No caso nacional, a discussão sobre a cultura da cana-de-açúcar em relação ao seu potencial em gerar energia renovável, em contribuir para a mudança no uso de combustíveis fósseis e em desenvolver um cenário agroenergético promissor é paralela àquela sobre seu potencial em modificar as regiões onde atua, já que uma expansão da produção de etanol na escala pretendida ocasionaria diversos tipos de impactos regionais, sejam eles diretos, indiretos, ou cumulativos, em todos os aspectos (sociais, econômicos, ambientais).

Dentro destes impactos, inclui-se no plano socioeconômico o aumento da densidade populacional, da necessidade de serviços de infraestrutura e de serviços públicos, comércio e atividades industriais, dentre outros. Estes também são efeitos que devem ser considerados em uma análise integrada de sustentabilidade.

Assim como observado nas iniciativas internacionais, também no plano nacional são verificadas construções de sistemas de certificação ambiental voltadas para os conceitos de sustentabilidade que se utiliza de critérios e indicadores para a avaliação da sustentabilidade da atividade (CGEE, 2009), principalmente com foco no comércio internacional. 
Logo, as empresas quando buscam a certificação (socioambiental) tratam as questões ambientais como um fator estratégico, em busca de um diferencial no mercado. Isto porque a certificação socioambiental visa diferenciação do produto ao assegurar que o mesmo é comprometido com o desenvolvimento sustentável (ex: diferenciação no processo de produção).

Ainda assim, Molina (2010, p. 44) coloca que "a certificação socioambiental representa um importante instrumento em busca do desenvolvimento mais sustentável", uma vez que as organizações necessitam passar por um processo de mudança organizacional envolvida em questões socioambientais para que consigam atingir os benefícios econômicos provenientes da certificação.

Observa-se, porém, a necessidade de incorporar os diversos agentes dentro de uma composição que discuta os valores e as necessidades observadas pelos diversos envolvidos, conduzindo assim a um entendimento de sustentabilidade partilhado por todos.

Desta forma, as discussões sobre sustentabilidade do etanol de cana-de-açúcar devem considerar um conceito de sustentabilidade que englobe as indicações expressas por Bossel (1999), Gallopin (2003) e Hammond (1995) num contexto integrado, capaz de incorporar apontamentos ambientais, sociais e econômicos na composição de políticas públicas, que conduza a tomadas de decisões eficientes, suportadas por informações qualificadas em tempo, eficácia e abrangência.

De uma forma geral a sustentabilidade é um conceito normativo, contendo valores, percepções e preferências que precedem uma análise técnica ou científica. Há também diversas maneiras de se definir conceitos e consequentemente indicadores para avaliar desenvolvimento sustentável. Com o objetivo de maximizar a eficiência na seleção de indicadores para o contexto do etanol de cana-de-açúcar a pesquisa lançou mão da estrutura metodológica que será apresentada e discutida no capítulo seguinte. 


\section{ANÁLISE E DISCUSSÃO DOS RESULTADOS}

O objetivo principal do trabalho desenvolvido foi propor uma estrutura de análise sobre a adequabilidade de indicadores ambientais, por meio de dois enfoques complementares:

a) Nas boas práticas de construção e utilização de indicadores: como estes necessitem ser para que possuam solidez analítica, credibilidade técnica, e outras características essenciais para um bom monitoramento e apresentação de resultados, considerados aqui como princípios de adequação técnica-científica;

b) Nas características essenciais que demonstram a inserção da visão de sustentabilidade no perfil dos indicadores, indicando a qualidade destes para apoio na tomada de decisão e representatividade nesta temática, sendo uma análise de reflexão conceitual.

Estes enfoques foram trabalhados de modo participativo, através de consultas diretas aos especialistas por meio de entrevistas semi-estruturadas e uma oficina de discussão, permitindo uma maior reflexão, discussão e delineamento para o alcance do objetivo.

Considerando estas duas abordagens adotadas pela pesquisa, bem como seu recorte estadual, optou-se, para escopo de investigação, os indicadores ambientais produzidos e divulgados pela Secretaria do Meio Ambiente - SMA e por suas instituições vinculadas, por sua importância devido a sua função dentro do SISNAMA e do SEAQUA, ao ser o responsável em realizar, além de seu o papel de planejador das políticas ambientais no âmbito estadual, o papel de controlador, fiscalizador e relator da situação do meio ambiente, tendo os indicadores ambientais como principal ferramenta para isto.

Com intuito de exemplificar de forma mais aprofundada a análise crítica foi escolhido o Índice, o Índice de Qualidade da Água (IQA), sendo que esta aplicação possibilitou encontrar os pontos fortes e fracos do indicador analisado. Contudo, este método pode se aplicado para qualquer outro indicador ou conjunto de indicadores que se queira avaliar.

Tal apresentação está disponível neste capítulo, bem como uma análise SWOT realizada com o objetivo de apresentar, de forma mais consistente e adequada à tomada de decisão os resultados do indicador analisado.

Da mesma forma que o método de avaliação, observa-se que a análise SWOT poderia também ser empregada a qualquer outro tipo de indicador, ou mesmo a um conjunto ou sistema de indicadores. A utilidade do método se encontra principalmente na maximização 
dos resultados de avaliação e emprego de indicadores ambientais para o suporte à tomada de decisão em políticas públicas rumo à sustentabilidade.

O quadro (Quadro 6.1) apresenta claramente os produtos obtidos e os procedimentos metodológicos que os geraram, sendo explicado detalhadamente em seguida.

\begin{tabular}{|c|c|c|}
\hline META & ATIVIDADES & PRODUTOS \\
\hline $\begin{array}{l}\text { 1. Levantamento e análise de } \\
\text { acervo bibliográfico. }\end{array}$ & $\begin{array}{l}\text { - Temas: } \\
\text { 1. Sustentabilidade } \\
\text { 2. Indicadores Ambientais } \\
\text { 3. Secretaria Estadual de Meio } \\
\text { Ambiente. } \\
\text { 4. Etanol de cana-de-açúcar }\end{array}$ & $\begin{array}{l}\text { Embasamento teórico para o } \\
\text { desenvolvimento da pesquisa e } \\
\text { para elaboração de método de } \\
\text { análise. }\end{array}$ \\
\hline $\begin{array}{l}\text { 2. Mapeamento dos indicadores } \\
\text { ambientais da Secretaria Estadual } \\
\text { do Meio Ambiente. }\end{array}$ & $\begin{array}{l}\text { - Identificação das instituições } \\
\text { que compõem a SMA e que } \\
\text { produzem informações ambientais } \\
\text { e assim o levantamento dos } \\
\text { indicadores } \\
\text { relacionados. }\end{array}$ & $\begin{array}{l}\text { Caracterização e sistematização } \\
\text { dos indicadores ambientais no } \\
\text { contexto da pesquisa. }\end{array}$ \\
\hline $\begin{array}{l}\text { 3. Apreciação e discussão das } \\
\text { bases conceituais sobre } \\
\text { indicadores ambientais e sua } \\
\text { relação com os impactos } \\
\text { negativos gerados pelo ciclo de } \\
\text { vida do etanol de cana-de-açúcar, } \\
\text { com apoio de especialistas. }\end{array}$ & $\begin{array}{l}\text { - Consulta aos especialistas- } \\
\text { Discussão sobre a pertinência dos } \\
\text { indicadores ambientais para a } \\
\text { seleção e análise. }\end{array}$ & $\begin{array}{l}\text { Elaboração e validação do método } \\
\text { de seleção baseado nos Impactos } \\
\text { Negativos Significativos em } \\
\text { relação ao ciclo de vida do etanol } \\
\text { de cana de cana-de-açúcar. } \\
\text { Obtenção dos indicadores-chave } \\
\text { para análise. }\end{array}$ \\
\hline $\begin{array}{l}\text { 4. Apreciação e discussão das } \\
\text { bases conceituais sobre os } \\
\text { critérios de análise. }\end{array}$ & $\begin{array}{l}\text { Oficina de especialistas } \\
\text { Discussão e decisão sobre quais e } \\
\text { como deveriam ser os critérios à } \\
\text { serem considerados na futura } \\
\text { análise para que conseguissem } \\
\text { apresentar os pontos fortes e fracos } \\
\text { dos indicadores ambientais chave. }\end{array}$ & $\begin{array}{l}\text { Composição e validação do método } \\
\text { de análise através da indicação, } \\
\text { modificação e subtração dos } \\
\text { critérios de boas práticas trazidos } \\
\text { da revisão bibliográfica. }\end{array}$ \\
\hline $\begin{array}{l}\text { 5. Aplicação ao estudo de caso e } \\
\text { SWOT }\end{array}$ & $\begin{array}{l}\text { Entrevista ao técnico especialista e } \\
\text { aplicação dos critérios de análise } \\
\text { para um indicador- chave. }\end{array}$ & $\begin{array}{l}\text { Conclusão sobre a eficiência do } \\
\text { procedimento metodológico para o } \\
\text { objetivo da pesquisa. }\end{array}$ \\
\hline
\end{tabular}

Quadro 6.1- Produtos obtidos por meio dos procedimentos metodológicos adotados

\subsection{Considerações sobre a base conceitual}

A consolidação da base teórica, na primeira etapa do trabalho, foi indispensável para a o entendimento de como devem ser os indicadores ambientais, independentemente de estes serem tradutores de impactos ou de estado do ambiente.

Por meio da revisão bibliográfica observou-se que os indicadores devem se assentar sobre critérios para desempenharem adequadamente seu papel de monitoria das modificações, da qualidade do meio ambiente e da efetividade deste monitoramento, conseguindo assim auxiliar no questionamento e no desenvolvimento sustentável. No caso específico desta pesquisa, tal debate se passa no contexto do etanol de cana-de-açúcar. 
Os critérios levantados e discutidos pela bibliografia passaram por um processo de avaliação por meio de consultas e por uma oficina, formadas por uma equipe de especialistas no tema. Os produtos deste método de validação dos critérios estão expostos no decorrer deste capítulo que discute também a aplicação do método em um indicador.

A escolha do etanol de cana-de-açúcar se deve à vanguarda do tema para a sociedade, estando este inserido como um dos principais produtos da busca pela sustentabilidade da matriz energética dos países.

Por meio da sistematização e discussão das informações contidas em documentos internacionais, de experiências e debates sobre indicadores ambientais, de organizações e instituições voltadas à discussão da sustentabilidade do etanol, o trabalho foi capaz de obter a real percepção da importância e força que esta problemática tem tido.

No caso nacional isto fica ainda mais evidente. A preocupação em encontrar um caminho que demonstre a integração do meio ambiente com a saúde da sociedade e os avanços para maior lucro não só uma meta do Estado de São Paulo, mas da Nação.

Tal perspectiva se faz presente nos planos e políticas voltadas para o setor energético que contemplam os produtos energéticos da indústria sucroalcooleira, em primeira instância o etanol, como produtos que devem ganhar em representatividade no cenário energético nacional no futuro.

Paralelamente, os indicadores ambientais têm sido usados para possibilitar a busca deste objetivo, principalmente pelos meios como as tentativas na elaboração de processos de certificação, ou projetos estratégicos com adesão voluntária, para relatar e comprovar controle aos órgãos fiscalizadores, enfim, todos estes meios se utilizam de indicadores ambientais.

Estes meios, ainda que possuam um perfil de tecnocentrismo complacente, em especial em sua divulgação, estão em grande parte condicionados a uma visão tecnocêntrica extremista, com interesses muito mais produtivos, de lucro econômico, de autorização para operação, ou possibilidade de comercialização internacional, o que demonstrou a inexistência de aplicação de indicadores voltados a uma perspectiva de sustentabilidade forte para a atividade canavieira e consequentemente para o etanol no Brasil.

Neste sentido, é ainda mais importante saber o quanto os indicadores ambientais da Secretaria Estadual do Meio Ambiente podem contribuir para apoiar as decisões voltadas à discussão da sustentabilidade do etanol.

Observou-se que na literatura brasileira tem havido discussões teóricas profundas tanto sobre os temas de sustentabilidade como para indicadores. Porém a prática tem demonstrado uma fragmentação, ou inércia na integração das distintas dimensões que deveriam compor a 
sustentabilidade, sempre sobressaindo uma dimensão mais do que outra, ou seja, maior discussão na dimensão ambiental, ou econômica ou social, mas quase nada factível sobre a integração destas para que pudessem conduzir a atividade, de alguma forma, a sustentabilidade.

Esse descompasso entre os diversos interesses, felizmente, tem criado a necessidade de um esforço intenso pelas partes envolvidas, tais como organizações representativas do setor, organizações não governamentais, institutos de pesquisa e do próprio governo para se adequarem a esta nova visão de integração, que é exigida pela idéia de sustentabilidade.

Observa-se que esta discussão não está apenas concentrada nas instituições de pesquisa e universidades, existindo uma grande gama de livros, relatórios e outras formas de publicações governamentais sobre o tema, por intermédio de seus diversos agentes.

De todos os aspectos, observa-se que é grande o emprego de indicadores ambientais para acompanhamento do desempenho, para estipulação de metas e para fiscalização e controle das ações voltadas à sustentabilidade.

\subsection{Fontes e método de obtenção dos indicadores (mapeamento)}

A publicidade, a participação popular e o acesso público e gratuito à informação são expressamente garantidos pela Constituição Federal (Ibid., arts. 5. , XXXIII; 37 e 225, parágrafo 1. , IV), bem como pela Lei da Política Nacional do Meio Ambiente (Lei Federal n. 6938/81), que prevê a obrigatoriedade do poder público manter um sistema nacional de informações sobre o meio ambiente, elaborar relatório de qualidade e prestar informações relativas ao meio ambiente, produzindo-as, quando inexistentes.

Neste mesmo contexto apresenta-se a Lei Federal 10650/03 que dispõe sobre o acesso público às informações e dados existentes nos órgão integrantes do SISNAMA, em meio escrito, visual, sonoro ou eletrônico, sendo que o prazo para ser fornecida a informação, resguardando sigilos industrial, comercial e financeiro, é de 30 dias.

Com isto, fica explícita a importância na investigação das fontes de informações, mais precisamente da condição de seus indicadores ambientais (por serem equivalentes a estas informações), e assim poder analisar suas forças e fraquezas no que se refere ao seu papel de ferramenta no processo decisório, no caso desta pesquisa, para etanol de cana-de-açúcar.

Considerando a grande quantidade e variabilidade de informações ambientais no Estado de São Paulo, dada a repartição de competências institucionais e a descentralização da gestão ambiental no país, seria inviável e improdutivo mapeá-los na totalidade, ainda que restritamente aos temas ar, água e vegetação. 
Por esse motivo, optou-se por testar o método de mapeamento dos indicadores ambientais (atmosfera, solo e água) e suas respectivas fontes de informação a partir dos Relatórios de Qualidade Ambiental (RQAs) produzidos pela Secretaria do Meio Ambiente (SMA), com a finalidade de apresentar um produto útil e factível. Nos RQAs as instituições relacionadas ao mapeamento, especificamente aos indicadores ambientais, foram aquelas que estão vinculadas à SMA, dada sua competência como fonte de informações e ao mesmo tempo sua importância institucional no Estado de São Paulo.

Todo o material analisado é composto por dados disponíveis e acessíveis à sociedade por meio de acesso online, publicados pelos Relatórios Ambientais vinculados ao endereço eletrônico da SMA. As informações mapeadas estão relacionadas aos indicadores físicoquímicos voltados aos componentes ambientais água, solo e ar que têm interface com o etanol de cana-de-açúcar.

Mesmo com a decisão de analisar os RQAs, foi importante entender como é a estruturação da Secretaria de Meio Ambiente do Estado de São Paulo e as funções de seus departamentos, núcleos e centros de análises dentro de suas respectivas temáticas ambientais.

Entretanto, foram realizadas duas entrevistas na SMA/SP. Uma destas entrevistas foi realizada junto à Coordenadoria de Planejamento Ambiental - CPLA; órgão responsável por elaborar e publicar o Relatório de Qualidade Ambiental Anual, o qual contém os principais temas e indicadores ambientais da SMA.

Contudo, mesmo com esta relevância, a CPLA não é a única a elaborar relatórios, algumas instituições da SMA também realizam este papel.

Observou-se que as informações produzidas pelas instituições vinculadas à SMA também são contempladas indiretamente, já que a CPLA se utiliza destas informações para formular o seu relatório geral com periodicidade anual. Todavia, a mesma indicou todos os outros RQAs produzidos separadamente por cada instituição que os realizam, sendo que estes também foram analisados no mapeamento. Os relatórios analisados para o mapeamento dos indicadores utilizados nesta pesquisa foram demonstrados no Quadro 2.2 do capítulo Materiais e Métodos.

A outra entrevista foi realizada junto ao Departamento de Desenvolvimento Sustentável da Coordenadoria de Biodiversidade e Recursos Naturais (CBRN), com o intuito de prover o entendimento necessário sobre como o conceito de sustentabilidade tem sido trabalhado por meio dos indicadores. A entrevista questionou sobre os indicadores ambientais no que se refere a elaboração e divulgação dos mesmos, sobre as instituições responsáveis por eles e sobre os trabalhos e relatórios existentes relacionados aos indicadores. 
De acordo com estas entrevistas foi posto que, dentro da nova estrutura da SMA, todas as suas instituições vinculadas (ver Figura 2.3 do capítulo 2) são coletoras de informações e cada uma trabalha e define as informações mais importantes para seu escopo de funções.

Porém são distintas estas informações, pois existem aquelas voltadas às instituições de pesquisa científica-tecnológica (ex. Instituto Botânico), outras voltadas a processos de gestão (como a Fundação Florestal dentro do Instituto Florestal que trabalha a gestão das unidades de conservação e que atualmente tem iniciado a elaboração de um índice de gestão de unidades de Conservação, com participação pública), e aquelas que trabalham com informações de estado e qualidade do meio ambiente, por meio de fiscalização (como a CETESB).

Cada uma destas instituições possui o seu próprio banco de dados e a troca de informações é feita por transações pelos diversos meios de comunicação, o que evidencia uma ausência de um banco de dados único, ou mesmo relacionado entre todos, demonstrando uma ausência na integração destas informações. Esta ausência é minimizada por meio da CPLA na sua função de organizadora e divulgadora de tais informações.

No que se refere aos RQAs da SMA, uma novidade no ano de 2009 foi a elaboração do Painel de Qualidade Ambiental, no formato mais simples do que os demais, com apresentação dos indicadores em formato qualitativo, através de cores e de desenhos com expressões faciais de bom, regular e ruim para os resultados, além de apresentar metas para aqueles que se mostravam ruins.

Esta inovação mostra certa preocupação sobre o nível de entendimento da sociedade sobre o que se pretende mostrar, pois, como visto anteriormente, a divulgação da informação somente não é garantia de informar, já que para isso se depende do formato da informação e da capacidade de entendimento do usuário de acordo com cada assunto.

Não obstante, este relatório trouxe propostas de dois novos indicadores ambientais, já com meta para os mesmos sendo alegados como objetivos para os próximos relatórios. São estes: Pegada Ecológica, relacionado à área total necessária para sustentar a população do Estado em função dos recursos naturais disponíveis para Energia, Agropecuária, Recursos Hídricos e Compensação de Emissões; e o índice de Conservação do solo que relaciona as condições físicas, químicas e biológicas do solo.

Isto mostra a importância dada na atualização do conjunto de indicadores ambientais para uma melhor análise de cenários, pensando em investigar sobre problemáticas que vão se tornando indispensáveis de discussão.

Paralelamente, evidenciou-se que a reestruturação da SMA em 2008 foi importante ao facilitar a integração entre as suas partes, apesar desta ainda ser deficiente, pois, na opinião 
dos entrevistados, o órgão sempre trabalhou de forma fragmentada, não havendo comunicação entre as coordenadorias, sendo que a partir desta data as coordenadorias têm trabalhado mais unidas no processo de planejamento e gestão ambiental.

Esta opinião ficou comprovada ao evidenciar que tanto os novos formatos de divulgação dos indicadores, como outros trabalhos (exemplo, os projetos estratégicos, caderno de planejamento por UGRIs, entre outros também em fase de amadurecimento) da SMA têm acontecido com o envolvimento de diferentes departamentos e centros inseridos nas coordenadorias e ainda, por uma articulação com outras secretarias (exemplo, Secretaria de Agricultura e Abastecimento) e fontes de informação (exemplo, IBGE).

Como expresso pelos entrevistados, em outrora o apoio destas fontes externas, no que se refere à disponibilização de dados, era difícil, com agentes demonstrando uma postura fechada. Segundo os entrevistados o órgão público coletor de informações era "dono" da informação, com uma visão perfeccionista, acreditando que tais dados necessitavam de melhor tratamento ou formato para poder disponibilizá-los.

De qualquer forma, não se busca uma discussão mais ampla sobre fontes externas de informações, uma vez que estas não estão no recorte desta pesquisa, mas sim as instituições componentes da SMA.

Entre as instituições componentes da SMA, os problemas que persistem são: a ausência de um banco de dados único, organizado e o acesso livre pela intranet para todos os departamentos. Isto porque, quando existe a necessidade da informação, principalmente quando são feitos os relatórios, é necessário entrar em contato e buscar na fonte produtora.

Todavia, de acordo com os entrevistados, este banco de dados único já está sendo elaborado em um processo coordenado pela CPLA com a pretensão de conclusão para o ano de 2011. A ideia é que este banco de dados único seja uma integração dos sistemas de informações ambientais já existentes (em todos os âmbitos), e que possa ser, de alguma forma, acessado por municípios e usuários dependentes desta informação.

\subsection{Sobre a escolha dos indicadores-chave (método de seleção dos indicadores)}

Uma equipe multidisciplinar foi usada na pesquisa, que contou com representantes de cada um dos três campos ambientais: água, ar e solo, juntamente com especialistas em planejamento, sustentabilidade integrada, sendo todos estes acadêmicos e consultores.

Para o procedimento de escolha dos indicadores, foram realizadas 3 consultas diretas e individuais, com os representantes dos componentes ambientais, sendo uma para cada componente . 
Esta equipe analisou os impactos ambientais negativos significativos do ciclo de vida do etanol de cana-de-açúcar levantados pela revisão bibliográfica.

Os impactos selecionados serviram como base de seleção dos indicadores ambientais que seriam considerados pertinentes para auxiliar na discussão do etanol e sua sustentabilidade.

Este esforço foi necessário uma vez que, após o mapeamento realizado junto aos RQAs, foram observados 410 indicadores ambientais. Deste montante, 27 indicadores foram eliminados previamente, por serem duplicados (presentes em mais de um relatório). Assim restaram 383 indicadores para a avaliação.

Ao separar destes 383 aqueles indicadores ambientais de responsabilidade da SMA e de suas instituições componentes resultaram em um número de 119 indicadores ambientais, ou seja, este conjunto representa somente aqueles indicadores produzidos no âmbito da SMA. (Para melhor visualização e compreensão vide Figura 6.1).

Ao mapear os indicadores dos Relatórios procurou-se obter um conjunto ligado diretamente a SMA e que pudesse ser analisado sobre sua possibilidade de utilização no que diz respeito a dar suporte à discussão sobre o etanol e a sua sustentabilidade.

Isto porque os indicadores ambientais mapeados possuem muitos recortes, como por exemplo: indicadores ambientais com interface na dimensão energética, indicadores ambientais do componente biodiversidade (não pertencente ao recorte deste trabalho), indicadores ambientais com interface na gestão e políticas, enfim, sendo escolhido para esta pesquisa somente o recorte relacionado aos impactos ambientais negativos da produção e consumo do etanol pertencente aos componentes água, solo e ar.

Por este motivo foi levantado os impactos considerados mais relevantes pela literatura relacionada aos impactos do ciclo de vida do etanol e por meio de saturação teórica obteve a seguinte lista de impactos negativos do ciclo de vida, aqui denominados impactos negativos significativos no etanol de cana-de-açúcar (ver Quadro 6.2).

Esta lista foi discutida e validada pelos especialistas ambientais consultados, sendo que estes puderam indicar alterações à relação causa-impacto apresentada pela esquematização do quadro. Assim, foi elaborada a relação final e válida de impactos (ver Quadro 6.2) que serviu de base para a seleção dos indicadores-chave (aqueles relevantes para o contexto do etanol).

Assim que foi definida esta base de seleção e validada pelos especialistas ambientais, por meio das mesmas entrevistas analisaram os indicadores pré-selecionados pela autora, validaram aqueles que poderiam ser relevantes a esta base e indicaram aqueles que poderiam 
ser descartados. Esta discussão foi baseada no material apresentado no APÊNDICE A. Este material facilitou o direcionamento das entrevistas, sendo que os especialistas podiam contribuir com sua opinião sobre alguns aspectos mais técnicos dos indicadores.

Entretanto, estes aspectos mais técnicos, questionados na entrevista não foram muito fáceis de serem respondidos por tais especialistas, pois mostrava a necessidade de conhecimento sobre o histórico e a "vida" do indicador, ou seja, se tratavam de detalhes que somente técnicos da própria fonte produtora do indicador conseguiriam debater.

Portanto, o único tópico respondido por todos os especialistas foi o tópico 1: Representatividade (qual é o grau de relação que o indicador tem com os impactos negativos significativos do etanol?). De qualquer forma, as respostas dos outros tópicos foram consideradas como complementação para a discussão na oficina geral.

Os especialistas pontuavam suas resposta de 0 a 5 devido ao grau de relação/relevância que o indicador tinha com o tópico discutido, onde 0 era nenhuma relevância e 5 era muita relevância. Com isso, foram considerados todos aquelas respostas com valor acima de 3 conseguindo um conjunto de 50 indicadores-chave para análise.

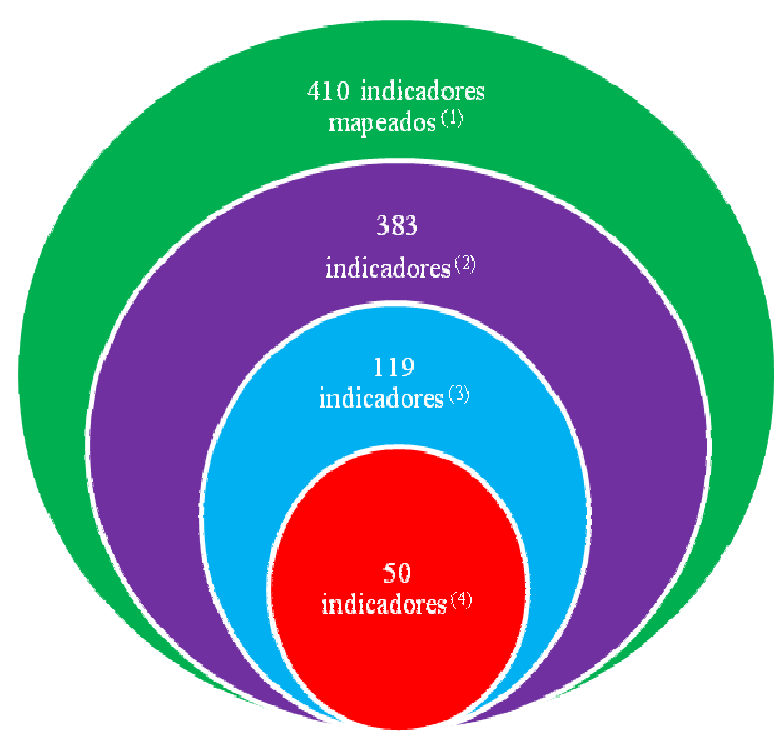

\footnotetext{
${ }^{1}$ Indicadores sistematizados e divulgados pelos Relatórios de Qualidade Ambiental.

${ }^{2}$ Retirados os indicadores duplicados e de outras dimensões (energéticos, biodiversidade, outros).

${ }^{3}$ Indicadores produzidos pelas instituições componentes da SMA/SP.

${ }^{4}$ Indicadores Ambientais pertinentes aos impactos negativos significativos do etanol de cana-de-açúcar Indicadores-chave para a análise.

Figura 6.1- Resultado do mapeamento dos indicadores ambientais
}

Este procedimento se mostrou válido para identificar a existência de indicadores que conseguissem cobrir os impactos ambientais negativos significativos gerados pelo ciclo de vida do etanol, principalmente pelo fato de tais indicadores não terem sido elaborados com este intuito diretamente. 


\begin{tabular}{|c|c|c|c|c|c|}
\hline $\begin{array}{c}\text { Componente } \\
\text { ambiental afetado }\end{array}$ & $\begin{array}{l}\text { Fase do ciclo de } \\
\text { vida }\end{array}$ & Atividade & Aspecto Ambiental & $\begin{array}{l}\text { Impactos Significativos } \\
\text { (Diretos) }\end{array}$ & Impactos Significativos (Indiretos de 1.ordem) \\
\hline \multirow{6}{*}{ Água } & \multirow{6}{*}{$\begin{array}{l}\text { Fase agrícola e } \\
\text { industrial }\end{array}$} & \multirow{6}{*}{$\begin{array}{c}\text { Utilização da } \\
\text { água no } \\
\text { processo } \\
\text { agrícola e } \\
\text { industrial }\end{array}$} & \multirow{2}{*}{ Consumo de água } & \multirow{2}{*}{$\begin{array}{c}\text { Redução da Disponibilidade } \\
\text { Hídrica }\end{array}$} & Diminuição de produtividade agrícola \\
\hline & & & & & Aumento de preços \\
\hline & & & \multirow{4}{*}{$\begin{array}{l}\text { Descarte em corpos d'água } \\
\text { superficiais }\end{array}$} & $\begin{array}{l}\text { Aumento de concentração de } \\
\text { sólidos sedimentados }\end{array}$ & Assoreamento de águas superficiais \\
\hline & & & & \multirow{3}{*}{$\begin{array}{l}\text { Aumento de demanda de } \\
\text { oxigênio - DBO e DQO } \\
\text { (água superficial) }\end{array}$} & Redução da potabilidade da água superficial \\
\hline & & & & & Diminuição da qualidade de vida aquática \\
\hline & & & & & Redução da qualidade hídrica \\
\hline \multirow{8}{*}{ Atmosfera } & \multirow{8}{*}{$\begin{array}{l}\text { Fase agrícola, } \\
\text { industrial, e de } \\
\text { consumo }\end{array}$} & \multirow{8}{*}{$\begin{array}{l}\text { Queimada / } \\
\text { transporte } \\
\text { /maquinário } \\
\text { agrícola e } \\
\text { caminhões/ } \\
\text { consumo de } \\
\text { etanol por } \\
\text { veículos } \\
\text { automotores }\end{array}$} & $\begin{array}{c}\text { Emissão de óxidos de carbono } \\
\text { (COx) }\end{array}$ & \multirow{3}{*}{$\begin{array}{c}\text { Formação fotoquímica do } \\
\text { Ozônio Troposférico }\end{array}$} & \multirow{8}{*}{ Aumento de Problemas respiratórios da população. } \\
\hline & & & Emissão de Hidrocarbonetos & & \\
\hline & & & $\begin{array}{l}\text { Emissão de Óxidos de } \\
\text { Nitrogênio (NOx) }\end{array}$ & & \\
\hline & & & Emissão de CH4 (metano) & \multirow{5}{*}{ Acidificação atmosférica } & \\
\hline & & & Emissão de Aldeídos & & \\
\hline & & & $\begin{array}{l}\text { Emissão de Óxidos de } \\
\text { Enxofre (SOx) }\end{array}$ & & \\
\hline & & & Fumaça & & \\
\hline & & & $\begin{array}{l}\text { Emissão de materiais } \\
\text { particulados }\end{array}$ & & \\
\hline \multirow{4}{*}{ Solo / água } & \multirow{4}{*}{ Fase agrícola } & \multirow{4}{*}{\begin{tabular}{|} 
Utilização de \\
maquinário \\
agrícola pesado \\
/ colheita \\
mecanizada
\end{tabular}} & \multirow{4}{*}{ Alteração física do solo } & Erosão & Assoreamento de águas superficiais \\
\hline & & & & $\begin{array}{l}\text { Incapacitação de retenção de } \\
\text { nutrientes }\end{array}$ & \multirow{2}{*}{ Redução do potencial produtivo do solo } \\
\hline & & & & $\begin{array}{l}\text { Incapacitação de retenção de } \\
\text { água } \\
\end{array}$ & \\
\hline & & & & $\begin{array}{c}\text { Diminuição da porosidade do } \\
\text { solo (compactação) }\end{array}$ & $\begin{array}{l}\text { Diminuição de produtividade por danos ao } \\
\text { desenvolvimento de raízes }\end{array}$ \\
\hline
\end{tabular}

(Continua ...) 


\begin{tabular}{|c|c|c|c|c|c|}
\hline $\begin{array}{c}\text { Componente } \\
\text { ambiental afetado }\end{array}$ & $\begin{array}{l}\text { Fase do ciclo de } \\
\text { vida }\end{array}$ & Atividade & Aspecto Ambiental & $\begin{array}{l}\text { Impactos Significativos } \\
\text { (Diretos) }\end{array}$ & Impactos Significativos (Indiretos de 1.ordem) \\
\hline \multirow{7}{*}{ Solo/água } & \multirow{7}{*}{ Fase agrícola } & \multirow{7}{*}{$\begin{array}{l}\text { Utilização de } \\
\text { agroquímicos }\end{array}$} & \multirow{4}{*}{$\begin{array}{l}\text { Escoamento / Lixiviação de } \\
\text { nutrientes aos mananciais }\end{array}$} & \begin{tabular}{|c|} 
Eutrofização de águas \\
superficiais (principalmente por \\
Nitrogênio e Fósforo)
\end{tabular} & $\begin{array}{l}\text { Aumento de demanda de oxigênio - DBO e DQO } \\
\text { (água superficial) }\end{array}$ \\
\hline & & & & $\begin{array}{l}\text { Salinização dos lençóis } \\
\text { freáticos }\end{array}$ & Toxidez do lençol freático \\
\hline & & & & \begin{tabular}{|c|} 
Diminuição da potabilidade dos \\
mananciais
\end{tabular} & Aumento de custos para tratamento de água \\
\hline & & & & Saturação do solo por Fósforo & Eutrofização de águas superficiais \\
\hline & & & \multirow{3}{*}{ Alteração química do solo } & Nitrificação do solo & Contaminação de mananciais por nitrato \\
\hline & & & & Salinização do solo & Diminuição de produtividade agrícola \\
\hline & & & & Saturação do solo por Potássio & Eutrofização de águas superficiais \\
\hline \multirow{8}{*}{ Solo / água } & \multirow{8}{*}{ Fase agrícola } & \multirow{8}{*}{$\begin{array}{l}\text { Utilização de } \\
\text { Vinhoto e/ou } \\
\text { torta de filtro }\end{array}$} & \multirow{3}{*}{$\begin{array}{c}\text { Infiltração no solo } \\
\text { (fertirrigação e } \\
\text { transbordamento de áreas de } \\
\text { sacrifício) }\end{array}$} & \begin{tabular}{|c|} 
Saturação da água subterrânea \\
por meio de lixiviação de \\
nutrientes (em especial por \\
Potássio e Nitrogênio) \\
\end{tabular} & Toxicidade do lençol freático \\
\hline & & & & $\begin{array}{l}\text { Aumento de demanda de } \\
\text { oxigênio - DBO e DQO } \\
\text { (água superficial) }\end{array}$ & \multirow[t]{2}{*}{$\begin{array}{l}\text { Redução da qualidade hídrica / da potabilidade } \\
\text { /Diminuição da população biótica. }\end{array}$} \\
\hline & & & & Acidificação de corpos dágua & \\
\hline & & & \multirow{5}{*}{$\begin{array}{l}\text { Lançamento do efluente em } \\
\text { mananciais / Escoamento } \\
\text { superficial (fertirrigação) }\end{array}$} & $\begin{array}{l}\text { Eutrofização da água } \\
\text { superficial (Principalmente } \\
\text { Fósforo) }\end{array}$ & $\begin{array}{c}\text { Aumento de demanda de oxigênio - DBO e DQO } \\
\text { (água superficial) }\end{array}$ \\
\hline & & & & $\begin{array}{c}\text { Acidificação do solo (baixo PH } \\
\text { da vinhaça) }\end{array}$ & $\begin{array}{l}\text { Redução da solubilidade de nutrientes (cálcio, } \\
\text { magnésio, fósforo, molibdénio, boro) para absorção } \\
\text { de raízes }\end{array}$ \\
\hline & & & & Salinização do solo & Diminuição de produtividade agrícola \\
\hline & & & & Nitrificação do solo & Contaminação de mananciais por nitrato \\
\hline & & & & $\begin{array}{l}\text { Salinização dos lençóis } \\
\text { freáticos }\end{array}$ & $\begin{array}{l}\text { Toxidez na água subterrânea causada por } \\
\text { concentração de íons específicos (principalmente } \\
\text { sódio, cloreto e boro) }\end{array}$ \\
\hline
\end{tabular}

\section{(Continua...)}




\begin{tabular}{|c|c|c|c|c|c|}
\hline $\begin{array}{c}\text { Componente } \\
\text { ambiental afetado }\end{array}$ & $\begin{array}{c}\begin{array}{c}\text { Fase do ciclo de } \\
\text { vida }\end{array} \\
\end{array}$ & Atividade & Aspecto Ambiental & $\begin{array}{c}\text { Impactos Significativos } \\
\text { (Diretos) }\end{array}$ & Impactos Significativos (Indiretos de 1.ordem) \\
\hline \multirow[t]{2}{*}{ Biodiversidade } & \multirow[t]{2}{*}{ Fase agrícola } & \multirow[t]{2}{*}{$\begin{array}{l}\text { Implementação } \\
\text { da monocultura }\end{array}$} & $\begin{array}{c}\text { Desmatamento / } \\
\text { descaracterização do } \\
\text { ambiente natural / remoção } \\
\text { da vegetação primitiva } \\
\end{array}$ & Redução da biodiversidade & $\begin{array}{c}\text { Aumento do risco de extinção das espécies mais } \\
\text { frágeis }\end{array}$ \\
\hline & & & Expansão da cultura & $\begin{array}{c}\text { Deslocamento de atividades } \\
\text { agropecuárias }\end{array}$ & Supressão de ecossistemas frágeis \\
\hline \multirow{4}{*}{ Solo } & \multirow{4}{*}{ Fase agrícola } & \multirow{4}{*}{ Queimada } & \multirow{4}{*}{ Alteração física do solo } & $\begin{array}{c}\text { Redução de microorganismos } \\
\text { no solo }\end{array}$ & \multirow{3}{*}{ Redução da biodiversidade } \\
\hline & & & & $\begin{array}{c}\text { Redução e danos à Fauna } \\
\text { existente na lavoura }\end{array}$ & \\
\hline & & & & $\begin{array}{l}\text { Redução entomológica } \\
\text { (insetos benéficos) }\end{array}$ & \\
\hline & & & & Erosão & Assoreamento de águas superficiais \\
\hline
\end{tabular}

Impactos desconsiderados para a seleção dos indicadores-chave (com interfaces mais fortes na dimensão econômica, social ou ao componente ambiental biodiversidade).

Quadro 6.2-Impactos negativos significativos levantados da literatura e discutidos pelos especialistas da área ambiental (água,solo e ar) 


\begin{tabular}{|c|c|c|c|c|c|}
\hline $\begin{array}{c}\text { Componente } \\
\text { ambiental } \\
\text { afetado }\end{array}$ & Fase do ciclo de vida & Atividade & Aspecto Ambiental & $\begin{array}{l}\text { Impactos Significativos } \\
\text { (Diretos) }\end{array}$ & $\begin{array}{c}\text { Impactos Significativos (Indiretos de } \\
\text { 1.ordem) }\end{array}$ \\
\hline \multirow{6}{*}{ Água } & \multirow{6}{*}{ Fase agrícola e industrial } & \multirow{6}{*}{$\begin{array}{c}\text { Utilização da } \\
\text { água no processo } \\
\text { industrial }\end{array}$} & \multirow{2}{*}{ Consumo de água } & \multirow{2}{*}{$\begin{array}{c}\text { Redução da Disponibilidade } \\
\text { Hídrica } \\
\end{array}$} & Diminuição de produtividade \\
\hline & & & & & Aumento de preços \\
\hline & & & \multirow{4}{*}{$\begin{array}{c}\text { Descarte de águas residuais } \\
\text { em corpos d'água superficiais }\end{array}$} & $\begin{array}{c}\text { Aumento de concentração de } \\
\text { sólidos sedimentados }\end{array}$ & $\begin{array}{c}\text { Contribuição para o assoreamento de águas } \\
\text { superficiais }\end{array}$ \\
\hline & & & & \multirow{3}{*}{$\begin{array}{c}\text { Aumento de demanda de } \\
\text { oxigênio - DBO e DQO } \\
\text { (água superficial) }\end{array}$} & Redução da potabilidade da água superficial \\
\hline & & & & & Diminuição da qualidade de vida aquática \\
\hline & & & & & Redução da qualidade hídrica \\
\hline \multirow{8}{*}{ Atmosfera } & \multirow{8}{*}{$\begin{array}{c}\text { Fase agrícola, industrial, } \\
\text { de transporte e de } \\
\text { consumo }\end{array}$} & \multirow{8}{*}{$\begin{array}{l}\text { Queimada / } \\
\text { transporte } \\
\text { /maquinário } \\
\text { agrícola e } \\
\text { caminhões/ } \\
\text { consumo de } \\
\text { etanol por } \\
\text { veículos } \\
\text { automotores }\end{array}$} & $\begin{array}{c}\text { Emissão de óxidos de carbono } \\
(\mathrm{COx})\end{array}$ & \multirow{3}{*}{$\begin{array}{c}\text { Formação fotoquímica do } \\
\text { Ozônio Troposférico }\end{array}$} & \multirow{2}{*}{$\begin{array}{l}\text { Aumento de Problemas respiratórios da } \\
\text { população. }\end{array}$} \\
\hline & & & \begin{tabular}{|l|} 
Emissão de Hidrocarbonetos \\
\end{tabular} & & \\
\hline & & & $\begin{array}{l}\text { Emissão de Óxidos de } \\
\text { Nitrogênio (NOx) }\end{array}$ & & \multirow{5}{*}{ Danos à flora } \\
\hline & & & Desconsiderado & \multirow{4}{*}{ Acidificação atmosférica } & \\
\hline & & & Desconsiderado & & \\
\hline & & & Desconsiderado & & \\
\hline & & & Fumaça & & \\
\hline & & & $\begin{array}{c}\text { Emissão de materiais } \\
\text { particulados }\end{array}$ & $\begin{array}{l}\text { Diminuição da qualidade da } \\
\text { água }\end{array}$ & Redução da qualidade hídrica \\
\hline \multirow{6}{*}{ Solo } & \multirow{6}{*}{ Fase agrícola } & \multirow{6}{*}{$\begin{array}{c}\text { Utilização de } \\
\text { maquinário } \\
\text { agrícola pesado / } \\
\text { colheita } \\
\text { mecanizada }\end{array}$} & \multirow{6}{*}{ Alteração física do solo } & \multirow[b]{2}{*}{ Erosão (hídrica) } & Perda de solo e nutrientes \\
\hline & & & & & $\begin{array}{c}\text { Contribuição para o assoreamento de águas } \\
\text { superficiais }\end{array}$ \\
\hline & & & & Diminuição da capacidade de & Redução do potencial produtivo do solo \\
\hline & & & & $\begin{array}{c}\text { retenção de nutrientes pelo } \\
\text { solo. }\end{array}$ & Aumento de uso de fertilizantes \\
\hline & & & & $\begin{array}{l}\text { Diminuição da capacidade de } \\
\text { retenção de água pelo solo }\end{array}$ & Escoamento e carregamento de nutrientes \\
\hline & & & & \begin{tabular}{|c|}
$\begin{array}{c}\text { Diminuição da porosidade do } \\
\text { solo (compactação) }\end{array}$ \\
\end{tabular} & Desconsiderado \\
\hline
\end{tabular}

(Continua...) 


\begin{tabular}{|c|c|c|c|c|c|}
\hline $\begin{array}{c}\text { Componente } \\
\text { ambiental } \\
\text { afetado } \\
\end{array}$ & Fase do ciclo de vida & Atividade & Aspecto Ambiental & $\begin{array}{l}\text { Impactos Significativos } \\
\text { (Diretos) }\end{array}$ & $\begin{array}{c}\text { Impactos Significativos (Indiretos de } \\
\text { 1.ordem) }\end{array}$ \\
\hline \multirow{10}{*}{ Solo/ água } & \multirow{10}{*}{ Fase agrícola } & \multirow{10}{*}{$\begin{array}{l}\text { Utilização de } \\
\text { agroquímicos }\end{array}$} & \multirow{7}{*}{$\begin{array}{l}\text { Escoamento / Lixiviação de } \\
\text { substâncias (sintéticas e } \\
\text { nutrientes) aos mananciais }\end{array}$} & $\begin{array}{c}\text { Eutrofização de águas } \\
\text { superficiais (N-P-K) }\end{array}$ & \multirow{2}{*}{$\begin{array}{l}\text { Aumento de demanda de oxigênio - } \\
\text { DBO e DQO (água superficial) }\end{array}$} \\
\hline & & & & $\begin{array}{c}\text { Contaminação Sintética de } \\
\text { corpos d'água }\end{array}$ & \\
\hline & & & & Desconsiderado & Desconsiderado \\
\hline & & & & $\begin{array}{c}\text { Diminuição da potabilidade } \\
\text { dos mananciais }\end{array}$ & Aumento de custos para tratamento de água \\
\hline & & & & \multirow[b]{2}{*}{ Erosão (hídrica) } & Perda de solo e nutrientes \\
\hline & & & & & $\begin{array}{c}\text { Contribuição para o assoreamento de águas } \\
\text { superficiais }\end{array}$ \\
\hline & & & & Desconsiderado & Desconsiderado \\
\hline & & & \multirow{3}{*}{ Alteração química do solo } & Nitrificação do solo & Contaminação de mananciais por nitrato \\
\hline & & & & Desconsiderado & Desconsiderado \\
\hline & & & & Acúmulo de P-K no solo & Eutrofização de águas superficiais \\
\hline \multirow{9}{*}{ Solo / água } & \multirow{9}{*}{ Fase agrícola e industrial } & \multirow{9}{*}{$\begin{array}{c}\text { Vinhoto e/ou torta } \\
\text { de filtro (industrial } \\
\text { e produtivo) }\end{array}$} & \multirow{4}{*}{$\begin{array}{c}\text { SOLO - Infiltração de } \\
\text { excesso de fertirrigação e } \\
\text { transbordamento de áreas de } \\
\text { sacrifício }\end{array}$} & $\begin{array}{c}\text { Acúmulo da água subterrânea } \\
\text { por meio de lixiviação de } \\
\text { nutrientes (em especial K-N ) }\end{array}$ & Contaminação do lençol freático \\
\hline & & & & \multirow{3}{*}{$\begin{array}{c}\text { Aumento de demanda de } \\
\text { oxigênio - DBO e DQO } \\
\text { (superficial) Acidificação de } \\
\text { corpos d'água }\end{array}$} & Redução da qualidade hídrica \\
\hline & & & & & Redução da potabilidade \\
\hline & & & & & Desequilíbrio da população biótica \\
\hline & & & \multirow{5}{*}{$\begin{array}{l}\text { ÁGUA - Lançamento do } \\
\text { efluente em mananciais / } \\
\text { Escoamento superficial } \\
\text { (fertirrigação) }\end{array}$} & $\begin{array}{c}\text { Eutrofização da água } \\
\text { superficial (Principalmente } \\
\text { Fósforo) }\end{array}$ & $\begin{array}{l}\text { Aumento de demanda de oxigênio - } \\
\text { DBO e DQO (água superficial) }\end{array}$ \\
\hline & & & & $\begin{array}{l}\text { Acidificação do solo ( baixo } \\
\text { PH da vinhaça) }\end{array}$ & $\begin{array}{l}\text { Redução da solubilidade de nutrientes } \\
\text { (cálcio, magnésio, fósforo, molibdénio, } \\
\text { boro) p/ absorção da raíz }\end{array}$ \\
\hline & & & & Desconsiderado & Desconsiderado \\
\hline & & & & Nitrificação do solo & Contaminação de mananciais por nitrato \\
\hline & & & & Desconsiderado & Desconsiderado \\
\hline
\end{tabular}

(Continua...) 


\begin{tabular}{|c|c|c|c|c|c|}
\hline $\begin{array}{l}\text { Componente } \\
\text { ambiental } \\
\text { afetado }\end{array}$ & Fase do ciclo de vida & Atividade & Aspecto Ambiental & $\begin{array}{l}\text { Impactos Significativos } \\
\text { (Diretos) }\end{array}$ & $\begin{array}{c}\text { Impactos Significativos (Indiretos de } \\
\text { 1.ordem) }\end{array}$ \\
\hline \multirow[t]{2}{*}{ Solo } & \multirow[t]{2}{*}{ Fase agrícola } & \multirow[t]{2}{*}{$\begin{array}{l}\text { Implementação da } \\
\text { monocultura }\end{array}$} & $\begin{array}{c}\text { Desmatamento / } \\
\text { descaracterização do } \\
\text { ambiente natural / remoção da } \\
\text { vegetação primitiva }\end{array}$ & Redução da biodiversidade & $\begin{array}{l}\text { Aumento do risco de extinção das espécies } \\
\text { mais frágeis }\end{array}$ \\
\hline & & & Expansão da cultura & $\begin{array}{l}\text { Deslocamento de atividades } \\
\text { agropecuárias }\end{array}$ & Supressão de ecossistemas frágeis \\
\hline \multirow{4}{*}{ Solo } & \multirow{4}{*}{ Fase agrícola } & \multirow{4}{*}{ Preparo do solo } & \multirow{4}{*}{$\begin{array}{l}\text { Remoção da cobertura } \\
\text { vegetal do solo }\end{array}$} & \multirow[b]{2}{*}{ Erosão (hídrica) } & Perda de solo e nutrientes \\
\hline & & & & & $\begin{array}{c}\text { Contribuição para o assoreamento de águas } \\
\text { superficiais }\end{array}$ \\
\hline & & & & \multirow[b]{2}{*}{ Erosão (Eólica) } & Carregamento de nutrientes \\
\hline & & & & & $\begin{array}{c}\text { Dispersão de material particulado e } \\
\text { partículas inaláveis }\end{array}$ \\
\hline \multirow{6}{*}{ Solo } & \multirow{6}{*}{ Fase agrícola } & \multirow{6}{*}{ Queimada } & \multirow{6}{*}{ Alteração física do solo } & $\begin{array}{c}\text { Redução de microorganismos } \\
\text { no solo }\end{array}$ & \multirow{3}{*}{ Redução da biodiversidade } \\
\hline & & & & $\begin{array}{l}\text { Redução e danos à Fauna } \\
\text { existente na lavoura }\end{array}$ & \\
\hline & & & & $\begin{array}{l}\text { Redução entomológica } \\
\text { (insetos benéficos) }\end{array}$ & \\
\hline & & & & \multirow{3}{*}{$\begin{array}{c}\text { Solo sem cobertura vegetal e } \\
\text { matéria orgânica }\end{array}$} & Erosão (hídrica) \\
\hline & & & & & Erosão (Eólica) \\
\hline & & & & & Aumento da evaporação do solo \\
\hline
\end{tabular}

Impactos desconsiderados para a seleção dos indicadores-chave (com interfaces mais fortes na dimensão econômica, social ou ao componente ambiental biodiversidade)

Alterações de itens pelos especialistas

Acréscimo de itens pelos especialistas.

Quadro 6.3- Impactos negativos significativos utilizados como base de seleção dos indicadores-chave 
O quadro de impactos negativos significativos apresenta uma relação determinística de causa-efeito, e considera somente impactos diretos e indiretos de até $1^{\mathrm{a}}$ ordem, evitando uma cadeia de relações muito ampla e consequentemente uma diminuição no grau de inferência ao contexto do etanol.

Ao observar detalhadamente os impactos listados se percebe uma repetição de muitos deles, já que as relações entre os componentes ambientais são sistêmicas, e, portanto, ao ter um impacto direto no componente solo, por exemplo, há um impacto indireto na água.

Por esse motivo, a Figura 6.2 apresenta um esquema mais claro, sem as sobreposições dos itens, para uma melhor compreensão de quais impactos negativos significativos foram utilizados para serem correlacionados aos 119 indicadores da SMA e assim resultar no grupo menor de 50 indicadores-chave.

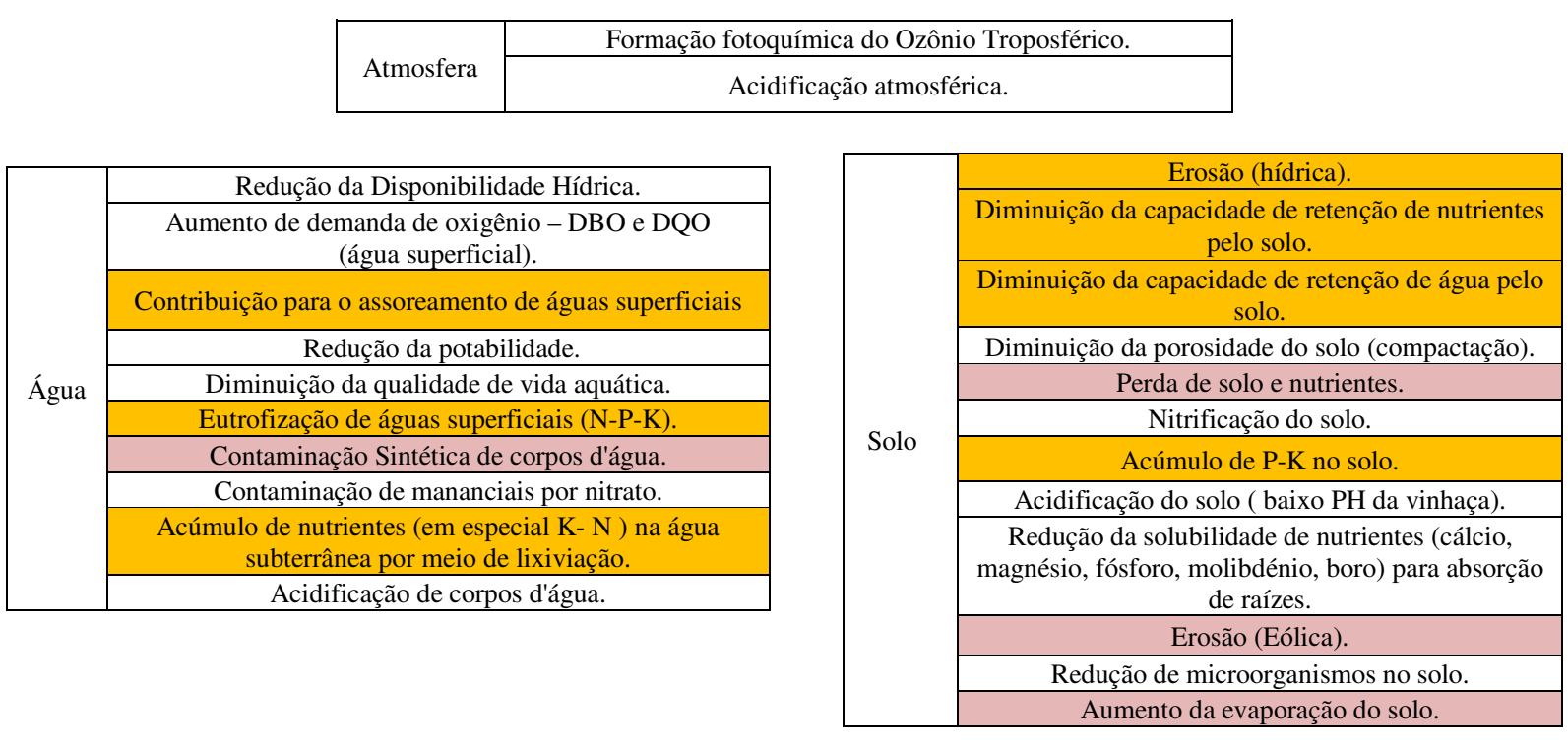

Alterações de itens pelos especialistas.

Acréscimo de itens pelos especialistas.

Figura 6.2- Representação simplificada dos impactos negativos significativos do ciclo de vida do etanol de canade-açúcar

A seguir (Figura 6.3) são apresentados os indicadores-chave por componente ambiental, sendo as descrições dos índices apresentadas no APÊNDICE D.

Como resultado da seleção dos indicadores-chave foram obtidos: 6 indicadores de água subterrânea, 35 indicadores de água superficial ${ }^{10}, 2$ indicadores de solo ${ }^{11}$, e 7 indicadores

\footnotetext{
${ }^{10}$ Indicadores repetidos na composição dos índices foram considerados uma única vez na contagem.

${ }^{11}$ Os mesmos indicadores de água subterrânea foram apresentados pelos RQAs como indicadores de solo e, portanto foram considerados somente uma vez na contagem.
} 
atmosféricos, totalizando 50 indicadores-chave relacionados aos impactos negativos significativos do ciclo de vida do etanol de cana-de-açúcar.

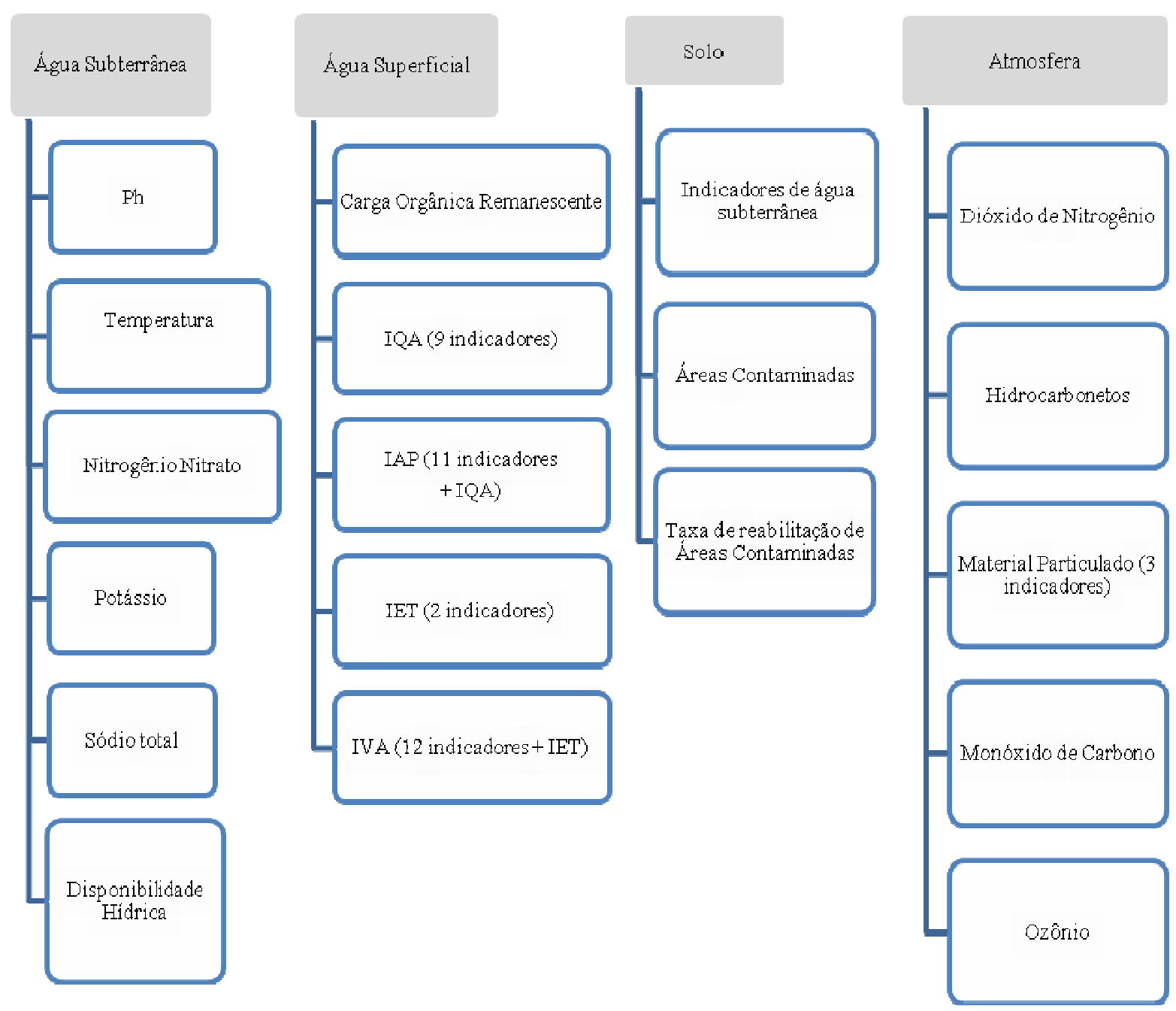

Figura 6.3- Conjunto de indicadores-chave correspondentes aos impactos negativos significativos do ciclo de vida do etanol de cana-de-açúcar

Lembrando que estes indicadores foram escolhidos com apoio dos especialistas ambientais (receberam pontuação 3 ou mais na tabela de análise utilizada para consultar o especialista - ver APÊNDICE A).

Os indicadores ambientais não selecionados correspondiam a outros componentes ambientais, ou simplesmente não apresentavam relação com os impactos negativos significativos do ciclo de vida do etanol de cana-de-açúcar.

Os impactos ambientais negativos significativos não cobertos pelos indicadores ambientais da SMA são: 


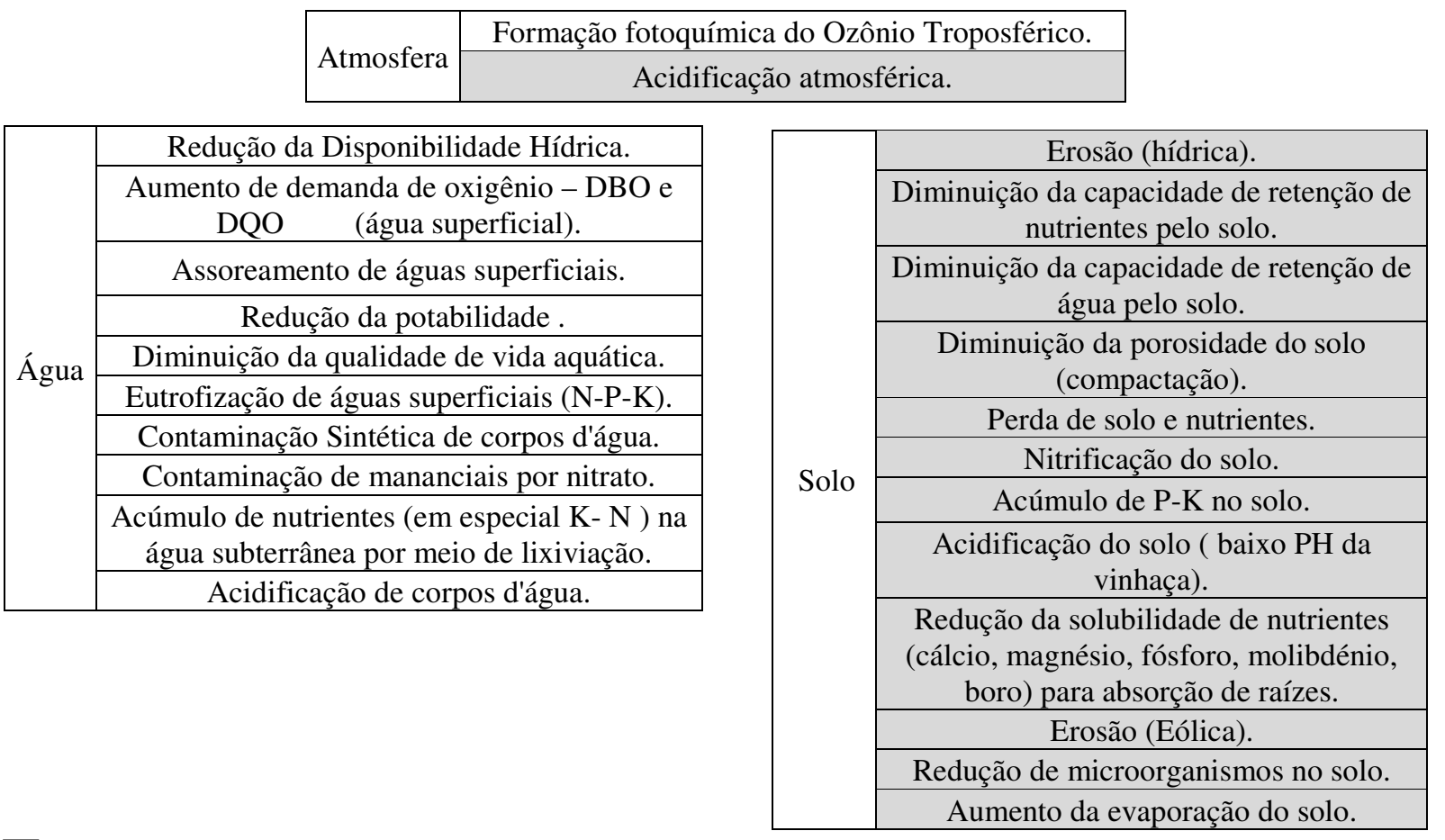

Impactos ambientais negativos significativos não cobertos pelos indicadores mapeados.

Figura 6.4- Impactos negativos significativos não cobertos pelos indicadores ambientais da Secretaria Estadual do Meio Ambiente

Este cenário já fora evidenciado quando, por meio do mapeamento, percebeu-se uma ausência de indicadores de solo, já que a maioria dos indicadores do tema eram os mesmos relacionados ao de impacto e/ou estado das águas subterrâneas.

Por outro lado, a água parece ser o tema mais significante, principalmente por sua extensa rede de monitoramento de coleta automática e manual, não minimizando a importância do tema atmosfera, o qual possui um cenário similar.

\subsection{Método de Análise}

Um time de especialistas foi usado para o desenho e validação do método de análise.

Este método se baseou nos princípios de boas práticas de elaboração e utilização de indicadores e foram colocados por meio de uma dinâmica em grupo em uma oficina para discussão (ver APÊNDICE B).

Estes especialistas são representantes dos temas: ambiental, sustentabilidade, indicadores e planejamento.

O grupo discutiu e analisou os vários princípios levantados pela bibliografia sobre indicadores, princípios estes de qualidade técnico-científica e de sustentabilidade, que foram apresentados no capítulo 4 e que foram pré-selecionados seguindo os critérios apresentados no capítulo 2. 
A dinâmica em grupo com o material de apoio permitiu adaptar, desconsiderar, ou simplesmente validar a pertinência de cada critério ${ }^{12}$ para o objetivo deste trabalho.

Ao mesmo tempo, os especialistas indicaram procedimentos a serem realizados para a aplicação do critério na análise, ou seja, indicaram quais os meios de verificar se aquele critério era ou não contemplado pelo indicador. Foram sugeridos procedimentos pela autora para alguns critérios, podendo estes também ser modificados pelos especialistas.

O Quadro 6.5 apresenta o resultado da oficina, já com as modificações sugeridas. Estes foram considerados critérios para a análise dos pontos fortes e fracos dos indicadores ambientais da SMA. A separação por categoria foi uma elaboração da autora para uma estruturação mais clara quanto às características comuns dos critérios.

\begin{tabular}{|c|c|c|c|}
\hline Categoria & Critério & Descrição & $\begin{array}{l}\text { Como verificar se este critério é contemplado } \\
\text { pelo indicador? O que deve ser feito ou checado? }\end{array}$ \\
\hline \multirow{5}{*}{$\begin{array}{l}\text { Validade e } \\
\text { Significância }\end{array}$} & $\begin{array}{l}\text { Representati- } \\
\text { vidade }\end{array}$ & $\begin{array}{l}\text { Refere-se à capacidade de } \\
\text { retratar os problemas da área } \\
\text { de estudo. }\end{array}$ & $\begin{array}{l}\text { Co-relacionar os indicadores com os } \\
\text { impactos ambientais negativos significativos } \\
\text { (método de seleção elaborado pela pesquisa). }\end{array}$ \\
\hline & Relevância & $\begin{array}{c}\text { Para ser representativo neste } \\
\text { sentido o indicador tem que } \\
\text { ser considerado importante } \\
\text { pelo seu usuário. }\end{array}$ & $\begin{array}{l}\text { Verificar se na construção do indicador e no } \\
\text { seu uso houve ou há um processo } \\
\text { participativo de discussão com os usuários. }\end{array}$ \\
\hline & Significância & $\begin{array}{l}\text { O indicador deve ser } \\
\text { relacionado a problemáticas } \\
\text { não somente de escala local } \\
\text { e sim de importância } \\
\text { nacional, global. }\end{array}$ & $\begin{array}{l}\text { Relacionar o indicador às maiores } \\
\text { problemáticas ambientais ligadas à } \\
\text { sustentabilidade do etanol, como por exemplo, } \\
\text { problemas com a água, mudança climática, } \\
\text { perda da biodiversidade, segurança alimentar, } \\
\text { etc. }\end{array}$ \\
\hline & $\begin{array}{l}\text { Valores de } \\
\text { Referência }\end{array}$ & $\begin{array}{l}\text { Os indicadores devem } \\
\text { utilizar-se de valores de } \\
\text { referência (meta ou um } \\
\text { limite) que incorporam a } \\
\text { capacidade de suporte do } \\
\text { meio. }\end{array}$ & $\begin{array}{l}\text { Checar a opinião do especialista perito }{ }^{1} \text { no } \\
\text { indicador. (ou) } \\
\text { Se utilizar de métodos que mostrem a } \\
\text { discrepância entre os valores de referência e a } \\
\text { capacidade de suporte, como por exemplo, } \\
\text { metodologia de uso da terra ou de aptidão } \\
\text { agrícola da terra, comparando o mapeamento } \\
\text { com o que esta sendo colocado como valores } \\
\text { de referência. }\end{array}$ \\
\hline & $\begin{array}{l}\text { Sensibilidade } \\
\text { às mudanças }\end{array}$ & $\begin{array}{l}\text { À medida que ocorrem as } \\
\text { alterações no ambiente, } \\
\text { mesmo que pequenas, a } \\
\text { resposta do dado é imediata, } \\
\text { mudando o seu valor; e se } \\
\text { for de natureza preventiva } \\
\text { que seja capaz de sinalizar a } \\
\text { degradação antes da } \\
\text { ocorrência de sérios danos. }\end{array}$ & $\begin{array}{l}\text { Consultar o especialista perito no indicador se } \\
\text { o método e a base de dados utilizados pelo } \\
\text { indicador levam em consideração as } \\
\text { mudanças do que se quer medir considerando } \\
\text { o ciclo do impacto ambiental significativo pra } \\
\text { observar se a método é sensível as mudanças. }\end{array}$ \\
\hline
\end{tabular}

(Continua...)

12 Para conhecimento dos critérios (princípios) apresentados inicialmente para discussão na oficina, ver o material utilizado na dinâmica no APÊNDICE B. 


\begin{tabular}{|c|c|c|c|}
\hline Categoria & Critério & Descrição & $\begin{array}{l}\text { Como verificar se este critério é contemplado pelo } \\
\text { indicador? O que deve ser feito ou checado? }\end{array}$ \\
\hline & $\begin{array}{l}\text { Séries } \\
\text { temporais }\end{array}$ & $\begin{array}{c}\text { Se a sensibilidade às } \\
\text { mudanças se mantém ao } \\
\text { longo do tempo, pode-se } \\
\text { gerar series temporais de } \\
\text { dados, ótimos tradutores } \\
\text { dos fenômenos de } \\
\text { diferentes dinâmicas em } \\
\text { um determinado tempo. } \\
\text { Quando for importante a } \\
\text { analise da evolução, os } \\
\text { indicadores devem ter a } \\
\text { capacidade de expressar } \\
\text { as mudanças em uma } \\
\text { escala de tempo } \\
\text { compatível com os } \\
\text { problemas. } \\
\end{array}$ & $\begin{array}{l}\text { Consultar o especialista perito no indicador para } \\
\text { verificar se o tipo de monitoramento que está } \\
\text { sendo feito é capaz de captar as oscilações que } \\
\text { ocorrem no aspecto mensurado (critério acima) e } \\
\text { se estes monitoramentos estão sendo realizados } \\
\text { com o objetivo de embasar avaliações futuras, } \\
\text { sejam de tendências e formação de cenários } \\
\text { futuros. Verificar se apresenta padrão histórico de } \\
\text { coleta e análise. }\end{array}$ \\
\hline & $\begin{array}{l}\text { Fácil } \\
\text { compreensão }\end{array}$ & $\begin{array}{l}\text { Indicadores devem ser } \\
\text { simples e fáceis de } \\
\text { compreender, para } \\
\text { informar o grupo de } \\
\text { pessoas que tomará as } \\
\text { decisões quantos aos } \\
\text { rumos do planejamento. } \\
\end{array}$ & $\begin{array}{l}\text { Utilizar-se da literatura pra descrever como seria } \\
\text { um indicador de fácil compreensão para e sua } \\
\text { justificativa. }\end{array}$ \\
\hline $\begin{array}{l}\text { Validade e } \\
\text { Significância }\end{array}$ & $\begin{array}{l}\text { Participação } \\
\text { popular }\end{array}$ & $\begin{array}{l}\text { A validação popular } \\
\text { assegura maior } \\
\text { compreensão e } \\
\text { importância ao indicador } \\
\text { pelos stakeholders. }\end{array}$ & $\begin{array}{l}\text { Este critério já seria contemplado uma vez que o } \\
\text { critério (Relevância) fosse observado. }\end{array}$ \\
\hline $\begin{array}{l}\text { Tipo de } \\
\text { informação }\end{array}$ & Preventiva & $\begin{array}{l}\text { O indicador ao ser } \\
\text { preventivo consegue } \\
\text { apoiar o processo de } \\
\text { decisão para avaliar a } \\
\text { sustentabilidade. }\end{array}$ & $\begin{array}{l}\text { Verificar se a informação trazida pelo indicador é } \\
\text { preventiva, ou somente descritiva sem a pretensão } \\
\text { de fornecer subsídios diretos à tomada de decisão. }\end{array}$ \\
\hline $\begin{array}{l}\text { Solidez } \\
\text { Analítica }\end{array}$ & $\begin{array}{l}\text { Validade } \\
\text { Científica }\end{array}$ & $\begin{array}{l}\text { Ter fundamentos } \\
\text { científicos e técnicos }\end{array}$ & $\begin{array}{l}\text { Este critério já seria contemplado uma vez que os } \\
\text { critérios (valores de referência, sensibilidade as } \\
\text { mudanças e séries temporais) fossem observados. }\end{array}$ \\
\hline $\begin{array}{l}\text { Mensurabilida } \\
\text { de }\end{array}$ & $\begin{array}{l}\text { Disponibilida } \\
\text { de e Acesso }\end{array}$ & $\begin{array}{l}\text { Estar disponível e ser } \\
\text { fácil de obter. }\end{array}$ & $\begin{array}{l}\text { Este critério já seria contemplado uma vez que o } \\
\text { critério (Atualização e divulgação) fosse } \\
\text { observado. }\end{array}$ \\
\hline $\begin{array}{l}\text { Mensurabilida } \\
\text { de }\end{array}$ & $\begin{array}{l}\text { Atualização e } \\
\text { divulgação }\end{array}$ & $\begin{array}{l}\text { Os dados precisam ser } \\
\text { coletados e reportados } \\
\text { regularmente, devendo } \\
\text { haver um tempo mínimo } \\
\text { entre a coleta e a } \\
\text { reportagem, para garantir } \\
\text { a atualidade e utilidade } \\
\text { para o usuário. }\end{array}$ & $\begin{array}{l}\text { Consultar o especialista perito no indicador para } \\
\text { verificar sobre a capacidade institucional do } \\
\text { sistema, se este é integrado e alimentado } \\
\text { periodicamente e como é divulgada esta } \\
\text { atualização. }\end{array}$ \\
\hline $\begin{array}{l}\text { Mensurabilida } \\
\text { de }\end{array}$ & $\begin{array}{l}\text { Abrangência } \\
\text { do indicador }\end{array}$ & $\begin{array}{c}\text { Deve haver } \\
\text { compatibilidade entre a } \\
\text { escala da informação e a } \\
\text { escala adotada para o } \\
\text { estudo. }\end{array}$ & $\begin{array}{l}\text { Confirmar com o especialista perito no indicador } \\
\text { se existem informações que justifiquem o modo } \\
\text { pelo qual o indicador foi delimitado } \\
\text { geograficamente e temporalmente. }\end{array}$ \\
\hline $\begin{array}{l}\text { Mensurabilida } \\
\text { de }\end{array}$ & Custo & $\begin{array}{l}\text { Em suma, pretende-se } \\
\text { que haja uma relação } \\
\text { custo/benefício razoável. }\end{array}$ & $\begin{array}{l}\text { Confirmar com o especialista perito no indicador } \\
\text { se o custo é sustentável para manter o indicador a } \\
\text { longo prazo. }\end{array}$ \\
\hline
\end{tabular}

(Continua...) 


\begin{tabular}{|c|c|c|c|}
\hline Categoria & Critério & Descrição & $\begin{array}{l}\text { Como verificar se este critério é contemplado pelo } \\
\text { indicador? O que deve ser feito ou checado? }\end{array}$ \\
\hline $\begin{array}{l}\text { Mensurabilida } \\
\text { de }\end{array}$ & $\begin{array}{l}\text { Conformidade } \\
\text { Temporal }\end{array}$ & $\begin{array}{l}\text { Deve-se averiguar o } \\
\text { tempo decorrido entre a } \\
\text { coleta do dado e a } \\
\text { realidade que se deseja } \\
\text { representar. Neste } \\
\text { aspecto, é evidente que } \\
\text { para cada temática, há um } \\
\text { intervalo de tempo } \\
\text { aceitável, que deve ser } \\
\text { julgado pelo seu } \\
\text { especialista. }\end{array}$ & $\begin{array}{l}\text { Este critério já seria contemplado uma vez que os } \\
\text { critérios (valores de referência, sensibilidade as } \\
\text { mudanças e séries temporais) fossem observados. }\end{array}$ \\
\hline \multirow{4}{*}{$\begin{array}{l}\text { Sistematização } \\
\text { do conjunto de } \\
\text { indicadores }\end{array}$} & Conectividade & $\begin{array}{l}\text { Conectividade do } \\
\text { indicador com outros do } \\
\text { meio, ou seja, os elos } \\
\text { entre as diversas } \\
\text { informações e as } \\
\text { respostas integradas às } \\
\text { suas mudanças. }\end{array}$ & $\begin{array}{l}\text { Critério válido somente para análise de um } \\
\text { conjunto de indicadores. }\end{array}$ \\
\hline & Integração & $\begin{array}{l}\text { É importante observar se } \\
\text { o indicador é integrador, } \\
\text { se tem a capacidade de } \\
\text { sintetizar informações de } \\
\text { vários outros indicadores. }\end{array}$ & $\begin{array}{l}\text { Critério inválido para analisar pontos fortes ou } \\
\text { fracos, pois dependendo da situação este critério } \\
\text { pode ser uma vantagem ou desvantagem. }\end{array}$ \\
\hline & $\begin{array}{l}\text { Uso de um } \\
\text { modelo } \\
\text { conceitual } \\
\text { estrutural }\end{array}$ & $\begin{array}{l}\text { Usado como guia para o } \\
\text { desenvolvimento e } \\
\text { estruturação de um } \\
\text { conjunto de indicadores, } \\
\text { de uma forma coerente. } \\
\text { Sem ele, o conjunto se } \\
\text { torna uma mistura } \\
\text { eclética de indicadores, } \\
\text { sem qualquer justificação } \\
\text { clara para a sua seleção. }\end{array}$ & $\begin{array}{l}\text { Critério válido somente para análise de um } \\
\text { conjunto de indicadores. }\end{array}$ \\
\hline & Redundância & $\begin{array}{l}\text { Deve se tomar cuidado } \\
\text { para que o indicador não } \\
\text { a apresente, ou seja, que } \\
\text { diferentes dados } \\
\text { coletados não expressem } \\
\text { a mesma informação. }\end{array}$ & $\begin{array}{l}\text { Critério válido somente para análise de um } \\
\text { conjunto de indicadores. }\end{array}$ \\
\hline
\end{tabular}

O especialista perito será aquele que participou da elaboração do indicador, ou que possui informação sobre seu histórico e utilização por ter ou estar trabalhando com o mesmo em sua fonte produtora.

Critérios modificados e/ou adaptados na oficina.

Critérios não utilizados para a aplicação neste estudo de caso.

Quadro 6.4- Resultados da oficina - critérios de análise

O resultado desta revisão foi aplicado como método de análise dos pontos fortes e fracos em um indicador para exemplificação, sendo estes critérios vistos como contribuição para futuros trabalhos que anseiem analisar a aptidão de um ou vários indicadores no apoio às decisões dentro da temática da sustentabilidade.

O diferencial deste conjunto de critérios está em agrupar características exigidas por um bom indicador com características técnicas, de controle, científico, dentre outras que requerem um olhar mais pragmático voltado à sustentabilidade, diminuindo a lacuna entre 
ciência e política, já que este olhar acrescenta maior linguagem, interesse e consenso entre os envolvidos, apoiando a reflexão para a tomada de decisão.

Ao embasar a política ambiental com indicadores desenhados por estes preceitos possivelmente se conseguiria influenciar mudanças de produção e consumo de uma forma que, aumentando a qualidade ambiental, aumentaria consequentemente o bem estar social e a estabilidade econômica. E isto não seria diferente para o caso do etanol.

\subsection{Aplicação do método de análise ao Índice de Qualidade da Água - IQA}

O método de análise foi aplicado para um único índice com o intuito de exemplificar e averiguar a eficiência dos procedimentos metodológicos propostos por esta pesquisa no que se refere a indicar os pontos fortes e fracos de indicadores ambientais e sua utilização para discutir sustentabilidade, aqui no que concerne ao etanol de cana-de-açúcar.

O índice escolhido é o Índice de Qualidade de Água - IQA, um dos mais conceituados e consolidados da SMA, devido principalmente ao seu histórico e por ter sido utilizado como base para a formulação de novos índices de qualidade de água.

Para bom emprego de alguns dos critérios foi consultado um especialista em água que com vasta experiência profissional junto à CETESB auxiliou nas discussões que necessitavam de informações mais específicas. Isto devido a tais informações que não são disponibilizadas por meio dos RQAs, visto que são questões mais técnicas e diversas vezes disponibilizadas apenas internamente, na fonte produtora do indicador.

Por isso a consulta ao especialista, aqui denominado como perito, foi baseada em uma entrevista semiestruturada (ver APÊNDICE C), a qual serviu de apoio para melhor direcionamento do parecer. O resultado da análise está representado na tabela a seguir e foi baseado em duas condições: nas informações dos RQAs, no conhecimento e na experiência do perito consultado sobre o indicador (Tabela 6.1).

Tabela 6.1: Resultados da análise dos pontos fortes e fracos do IQA

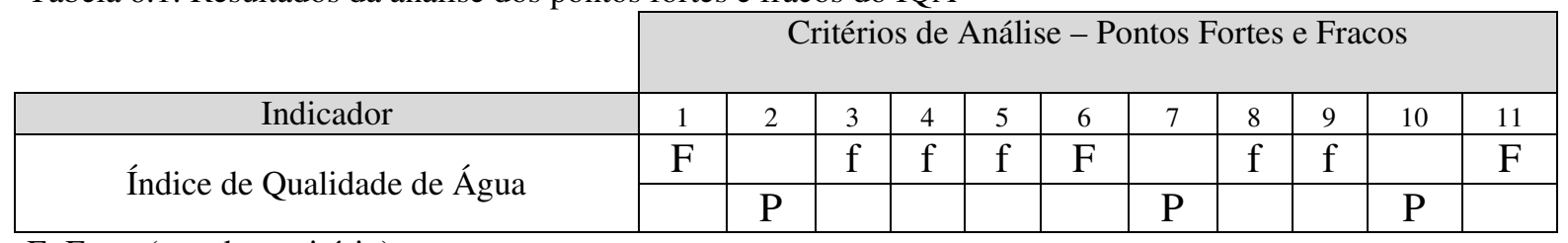

F- Forte (atende o critério).

$\mathrm{f}$ - fraco (não atende o critério).

$\mathrm{P}$ - Atende parcialmente o critério.

A seguir, observa-se a caracterização do índice, bem como as considerações sobre os resultados da aplicação do método de análise demonstrado na Tabela 6.1. 


\subsubsection{Caracterização do IQA}

O Índice de qualidade de água foi originado pelos mesmos motivos que todos os índices e indicadores ambientais: para informar a sociedade sobre os aspectos ambientais do desenvolvimento e para fundamentar o processo decisório das políticas públicas e sua avaliação (SMA, 2009).

Este índice tem sido utilizado pela CETESB desde 1975 com intuito de servir de informação básica sobre a qualidade de água para o público em geral, bem como para a gestão dos recursos hídricos. O mesmo é uma adaptação desenvolvida pela CETESB a partir de um estudo realizado pela National Sanitation Foundation dos Estados Unidos (CETESB, 2008b).

Sua composição possui nove parâmetros: temperatura, pH, oxigênio dissolvido, demanda bioquímica de oxigênio, coliformes termotolerantes, nitrogênio total, fósforo total, resíduos totais e turbidez.

A partir do cálculo do índice, pode-se determinar a qualidade das águas brutas, que é indicada por uma escala de 0 a 100, representado na Tabela 6.2.

\begin{tabular}{|c|c|}
\hline Categoria & Ponderação \\
\hline ÓTIMA & $79<\mathrm{IQA} \leq 100$ \\
\hline $\mathrm{BOA}$ & $51<\mathrm{IQA} \leq 79$ \\
\hline REGULAR & $36<\mathrm{IQA} \leq 51$ \\
\hline RUIM & $19<\mathrm{IQA} \leq 36$ \\
\hline PÉSSIMA & $\mathrm{IQA} \leq 19$ \\
\hline
\end{tabular}

Fonte: CETESB (2008b)

6.5.2 Análise dos pontos fortes e fracos do IQA

Nesta seção serão explicados os resultados (Tabela 6.1) da análise sobre os pontos fortes e fracos do IQA, discutindo o quanto este índice é capaz de auxiliar na tomada de decisão relacionada ao questionamento da sustentabilidade do etanol de cana-de-açúcar.

\section{Representatividade}

Este critério já foi considerado válido (forte) desde o momento que o IQA foi selecionado para a análise (consulta ao especialista), pois o critério refere-se à capacidade do indicador em retratar os problemas ambientais relacionados ao contexto do estudo. Se este critério não tivesse sido considerado válido o índice não seria se quer selecionado para a 
análise, o que mostra que não há possibilidade de outro resultado, uma vez que o indicador já esteja em processo de análise.

O IQA tem relação próxima com os impactos negativos significativos gerados pela produção do etanol na qualidade da água (ver Quadro 6.5), devido principalmente aos parâmetros: $\mathrm{pH}$, oxigênio dissolvido, demanda bioquímica de oxigênio, nitrogênio total, fósforo total, resíduos totais e turbidez, ou seja, sete parâmetros dos nove totais.

\begin{tabular}{|c|c|}
\hline \multirow{10}{*}{ Água } & Redução da Disponibilidade Hídrica. \\
\hline & $\begin{array}{c}\text { Aumento de demanda de oxigênio - DBO e } \\
\text { DQO (água superficial). }\end{array}$ \\
\hline & Assoreamento de águas superficiais. \\
\hline & Redução da potabilidade. \\
\hline & Diminuição da qualidade de vida aquática. \\
\hline & Eutrofização de águas superficiais (N-P-K). \\
\hline & Contaminação Sintética de corpos d'água. \\
\hline & Contaminação de mananciais por nitrato. \\
\hline & $\begin{array}{l}\text { Acúmulo de nutrientes (em especial K- N ) na } \\
\text { água subterrânea por meio de lixiviação. }\end{array}$ \\
\hline & Acidificação de corpos d'água. \\
\hline
\end{tabular}

\section{Relevância}

O IQA é uma adaptação de uma experiência americana para a realidade brasileira, que começou a ser utilizado pela CETESB a mais de três décadas.

De acordo com o perito entrevistado, nesta época não havia abertura para participação, sendo que na sua elaboração houve uma representação maior de técnicos das ciências exatas, sem muita abertura até para especialistas de outras áreas.

Como relatado, atualmente ao fazer os índices de água (Índice da Qualidade de Água para a Proteção da Vida Aquática (IVA), Índice de Qualidade de Água Bruta para Fins de Abastecimento Público (IAP), Índice de Balneabilidade (IB)) já são realizadas oficinas, debates com especialistas diversos, sendo que há a participação nestes fóruns de discussão das organizações não governamentais, de profissionais da academia e de representantes dos comitês de bacia. De qualquer forma isto não aconteceu na elaboração do IQA, pois a visão de processo participativo não era a mesma de hoje.

Todavia pode-se dizer que existe indiretamente a discussão participativa do IQA uma vez que os outros índices mais novos são compostos pelo próprio IQA, e ainda, estes novos índices de água, foram originados devido a críticas ao IQA, sendo adicionados novos parâmetros, e assim compondo esses novos índices. 
Deste modo, no caso desta análise a relevância do IQA foi considerada parcial, já que a participação pelo usuário na discussão de sua importância é indireta, porém os novos índices são como uma evolução do IQA.

Ao mesmo tempo, na opinião de alguns participantes da oficina, para o IQA seria desnecessária a participação pública na sua elaboração e discussão, por ele ser um indicador físico-químico de perfil técnico e de regulamentação.

Porém, um indicador tem melhores condições de se tornar útil ao usuário se for considerado válido não apenas cientificamente, mas ao prover informações relevantes a estes, desde que estas informações sejam vistas como importantes por eles. Caso contrário, o indicador pode apresentar um custo/benefício desfavorável.

\section{Significância}

A temática água é vinculada a qualquer contexto de produção seja ele agrícola ou industrial, pois estas atividades podem representar uma potencial ameaça à qualidade dos recursos hídricos.

Ao voltá-la para a discussão da sustentabilidade do etanol, sua importância se torna evidente, principalmente analisando o ciclo de vida do produto, o qual mostra claramente que, ainda que a atividade canavieira do estado em sua fase agrícola não se utilize de grandes volumes do recurso (já que o processo de irrigação se dá pelo reuso da água proveniente do sistema produtivo), esta realidade não se apresenta a mesma na fase industrial.

Mas ao se falar de IQA o foco é qualidade do recurso hídrico, mais especificamente da água superficial, não sendo seu objetivo calcular a quantidade utilizada deste recurso.

Neste quadro a problemática tem interface com outro componente ambiental, o solo. O manejo do solo possui influência direta sobre os impactos dos corpos d'água, desde o carregamento de solo e nutrientes aos mananciais (causando eutrofização e assoreamento), até o comprometimento da qualidade das águas superficiais e subterrâneas por meio de contaminação sintética por produtos químicos.

Assim sendo, a qualidade da água obtida através do IQA apresenta algumas limitações, pois o índice não contempla parâmetros como, por exemplo, metais pesados, compostos orgânicos com potencial mutagênico, número de células de cianobactérias, pois estes são considerados por outros índices de água (CETESB, 2008b).

A partir de 2002, a CETESB começou a utilizar índices específicos para cada uso do recurso hídrico (IAP - Índice de Qualidade de Águas Brutas para Fins de Abastecimento Público; IVA - Índice de Preservação da Vida Aquática, IB - índice de Balneabilidade) o que 
reflete que os índices estão sendo aprimorados com o tempo, pois as diferenças entre eles observadas são somente as variáveis de interesse. Mesmo assim o IQA se mostra adequado para trazer informações importantes, no que se refere aos seus parâmetros, sobre os impactos negativos gerados por uma produção inapropriada do etanol.

Contudo, considerando que o critério significância implica no potencial do indicador em refletir questões em esfera não apenas local, regional, mas também nacional e global, o IQA se mostra limitado para discutir a sustentabilidade do etanol, uma vez que seria necessária a incorporação de outros parâmetros não considerados por ele.

Sua significância está mais associada tanto à Legislação Estadual (Decreto Estadual 8468/76) quanto à Federal (Resolução CONAMA 357/05), que estabelecem o uso preponderante do recurso hídrico, dentre outros, para abastecimento público, sendo este a principal importância no uso do IQA.

O seu valor também é estabelecido por ele apresentar informação pública sobre o estado das águas no território paulista por meio do Relatório de Situação dos Recursos Hídricos (Lei Estadual 7.663/91), o qual tem periodicidade anual, e ao mesmo tempo contribuindo para o cumprimento das metas do Plano Estadual de Recursos Hídricos.

Sabendo que a diminuição da qualidade das águas superficiais e de reservatórios por ele representado é diretamente relacionada a práticas inadequadas na produção do etanol, este índice se torna oportuno ao questionamento sobre a sustentabilidade da atividade, porém com fraca significância.

\section{Valores de Referência}

Com o aumento da pressão sobre os recursos naturais, a capacidade de suporte tem sido uma preocupação cada vez mais presente na área ambiental. A capacidade de suporte é o ponto além do qual a pressão sobre o recurso o levaria a uma deterioração inaceitável.

Ao observar o IQA utilizado pela CETESB nota-se que este índice apresenta uma fragilidade em relação à consideração da capacidade de suporte, tendo em vista que seus valores são derivados de padrões fixos para seus parâmetros.

Uma vez que a capacidade de suporte não é fixa de acordo com os distintos ecossistemas, o índice (IQA) não possui esta sensibilidade, pois ele se utiliza no seu cálculo de padrões fixos para a representatividade e interpretação de seus parâmetros desconsiderando estas diferenças.

Ainda que o IQA utilizado pela CETESB tenha sofrido uma alteração em relação ao IQA original com o objetivo de refletir melhor a realidade do Estado de São Paulo (através da 
consideração da contaminação das águas por esgoto doméstico), esta adaptação não o torna capaz de considerar a capacidade de suporte, tendo em vista que esta alteração se dá apenas nos parâmetros de análise, continuando a utilizar valores de referência fixos para suas curvas de variação e peso relativo de seus parâmetros, bem como a interpretação de seus resultados.

\section{Sensibilidade às mudanças}

À medida que ocorrem as alterações no ambiente, mesmo que pequenas, a resposta do dado deve ser imediata, mudando o seu valor; sinalizando a degradação antes da ocorrência de sérios danos.

O tipo de monitoramento para cada parâmetro inserido no IQA difere de acordo com o ponto a ser monitorado, sendo que em alguns locais o monitoramento é feito por meio automático, e, à medida que ocorrem as alterações no ambiente a resposta do dado é imediata.

Porém, nos locais que o monitoramento é feito manualmente, a frequência de análise distingue-se, diminuindo a capacidade do índice em sinalizar a degradação, dependendo do ciclo do impacto.

Portanto o índice de qualidade de água se mostra insensível a mudanças bruscas dos parâmetros mensurados manualmente, o que faz com que este índice não tenha capacidade de informar o usuário em tempo hábil para tomada de decisão.

\section{Séries temporais}

Sobre o critério de séries temporais, observa-se que as séries de dados, de forma isolada, não são capazes de prover informações válidas à tomada de decisão. É necessário que haja um esforço de análise das séries temporais que permita ao analista observar o comportamento da série fornecendo assim os subsídios para a formulação de cenários futuros.

É por meio destas perspectivas de comportamento das séries que será possível avaliar os cenários e tomar decisões de políticas públicas realmente sustentáveis.

Neste sentido o indicador deve ser capaz de capturar, por sua rede de monitoramento, as alterações inter e entre os ciclos hidrológicos. De acordo com o perito consultado, a frequência do monitoramento é adequada, contemplando estes aspectos.

$\mathrm{O}$ mesmo indicou que o monitoramento passou de mensal para bimestral numa tentativa de minimizar os custos de monitoramento. Esta foi também uma decisão técnica uma vez que foi realizado um estudo prévio através de um teste de hipótese para verificar a possibilidade disto. Segundo o perito este teste demonstrou que não haveria prejuízos para a série caso houvesse esta alteração. 
Não obstante, para confiabilidade da série o perito explica que o monitoramento é realizado em pontos fixos com intervalo contínuo, o que garante fidedignidade aos dados e principalmente às eventuais análises realizadas sobre estes dados. Outro ponto importante a ser considerado é o tamanho da série, uma vez que o índice já vem sendo calculado por mais de 30 anos, fornecendo uma base de dados consistente para a análise. Com isto, entende-se que sobre o critério séries temporais o indicador apresenta-se forte.

\section{Fácil compreensão}

Os problemas complexos do desenvolvimento sustentável necessitam de índices, pois os tomadores de decisão se utilizam destes índices no processo decisório por serem, desconsiderando as exceções, facilmente entendíveis (VAN BELLEN, 2005).

As principais vantagens de um índice estão na facilidade de comunicação com o público leigo e no fato de representar diversas variáveis em um único número.

Contudo, alguns autores interpretam que o alto nível de agregação intensifica a percepção dos problemas, porém perdem ou escondem informação em cada estágio de agregação; informações estas potencialmente valiosas na orientação de ações para melhoria da sustentabilidade ou solução de problemas. (MEADOWS, 1998; BOSSEL, 1999; GALLOPÍN, 1997; SANTOS, 2004; REED, FRASER e DOUGILL, 2006)

Por este motivo, os índices devem permitir sua abertura para que as informações das variáveis individuais e a interação entre as mesmas possam ser consultadas, sendo que esta ação deve ser fácil a ponto de possibilitar a averiguação mais detalhadas. Portanto, um índice forte com olhar na sustentabilidade deve, ao mesmo tempo, fornecer uma avaliação integrada e permitir uma análise detalhada e compreensível por meio da desagregação de suas variáveis.

O IQA não permite que esta desagregação seja realizada pelo usuário, sendo que a informação mais detalhada de seus parâmetros dependeria de divulgação por meio online ou pelos RQAs, ação que não ocorre uma vez que este índice tem sido usado com intuito de transmitir uma avaliação integrada. Por outro lado, sua representação é tanto quanti como qualitativa (através de cores) facilitando para o usuário compreender o limiar de seus valores.

Sendo assim, o critério foi considerado parcialmente contemplado ao se considerar na análise estas vantagens e desvantagens do índice.

\section{Informação Preventiva}

No caso do índice de qualidade de água alguns de seus parâmetros são monitorados em tempo real, como é o caso do oxigênio dissolvido, porém a maioria se utiliza de medições 
por monitoramento manual, sendo necessário então um tempo maior dependente da coleta e tratamento dos dados para se ter uma avaliação, ou seja, somente depois que aconteceu o dano é que se consegue ter conhecimento e fazer o controle se possível.

Neste sentido a informação indicada pelo IQA de uma forma geral se mostra prescritiva, analítica, porém com recomendações posteriores a uma modificação no meio, se tornando muito mais um dado histórico sobre o que já ocorreu do que uma informação que subsidie diretamente a tomada de decisão.

Neste sentido, seria importante que todos os seus parâmetros fossem monitorados de tal forma que se obtivesse pelo menos um alerta sobre oscilações importantes, sendo assim possível de prevenir ou entender o problema antes de seu agravamento.

Na opinião do perito, uma vez que o parâmetro oxigênio dissolvido (OD) possui um monitoramento nessas condições, e que uma oscilação severa nos resultados dos outros parâmetros influenciaria nas concentrações de OD, o mesmo considera então parcial a apreciação deste critério pelo índice.

Porém, não se considera a existência de limiares para influência do OD por outros parâmetros. Sendo assim, é possível que ocorram variações importantes nos outros parâmetros, contudo em volumes insuficientes para desencadear uma reação que provoque uma variação também no OD.

Dada esta probabilidade de ocorrência, bem como a sua incapacidade de utilização para ações preventivas, o índice se mostra fraco neste critério.

\section{Atualização e divulgação}

De acordo com o perito entrevistado a atualização do índice de qualidade de água acontece por um sistema integrado internamente, de acordo com o período de tratamento dos dados, mas não é feita da mesma forma para os usuários externos, sendo que estes devem esperar a sua atualização por meio da divulgação, que acontece pelos RQAs anuais, como o Relatório de Qualidade Ambiental do Estado de São Paulo (organizado pela CPLA/SMA) e o Relatório de Situação dos Recursos Hídricos no Estado de São Paulo (elaborado pela Coordenadoria de Recursos Hídricos - CRHi/SMA).

Os índices IVA e IAP são disponibilizados online bimestralmente e, portanto, indiretamente, o IQA estaria sendo divulgado já que estes índices contêm os parâmetros do IQA na sua composição. Porém os resultados não são atualizados periodicamente no site, encontrando muitas vezes a informação correspondendo somente há anos anteriores (3 a 4 anos atrás). 
Esta situação mostra um interesse muito maior em apresentar os índices para a sociedade do que utilizá-los online para informar.

Por meio desta investigação, esta análise desconsidera que este critério tenha sido contemplado, ainda que seja possível "baixar" os RQAs diretamente do site da SMA, tendo em vista que estes relatórios trazem informações de anos anteriores e não dos últimos monitoramentos (resultados).

\section{Abrangência do indicador}

O perito especialista foi consultado sobre o modo pelo qual o indicador é delimitado geograficamente e temporalmente. $\mathrm{O}$ mesmo indicou que o monitoramento passou de mensal para bimestral a partir de 2008 numa tentativa de minimizar os custos de monitoramento.

Esta modificação, afirma o perito, sofreu um estudo prévio para verificar a possibilidade de tal mudança relacionada à escala temporal e este estudo apontou eficácia e ausência de prejuízos para a confiabilidade da série e da análise de tendência caso houvesse esta alteração. Ao comentar sobre a compatibilidade da escala geográfica da informação, o especialista explica que o monitoramento é realizado em pontos fixos com intervalo contínuo, o que garante confiabilidade as análises realizadas sobre estes dados.

Estes pontos fixos são ou a jusante de uma indústria ou a montante de uma captação, pertencentes a uma rede de monitoramento de águas superficiais que hoje possui 408 pontos de monitoramento: 333 estações manuais, 13 estações automáticas (dados em tempo real), 26 pontos de análise de sedimento dos corpos d'água e 36 estações de diagnóstico de balneabilidade. Em 1974 quando a operação da rede de monitoramente iniciou havia 47 pontos de amostragem.

A densidade da rede de monitoramento é de 2,21 pontos $/ 1.000 \mathrm{~km}^{2}$, bem acima do valor recomendado pela União Europeia (1 ponto / $1.000 \mathrm{~km}^{2}$ ). Todavia, este valor não é representativo se analisarmos o Estado em sua totalidade, uma vez que grande parte destes pontos se concentra em apenas quatro UGRHIs, as principais em termos de densidade populacional.

Com o intuito de avaliar o modo de controle da qualidade dos recursos hídricos a Coordenadoria de Recursos Hídricos da SMA tem trabalhado com um indicador recente chamado Densidade da Rede de Monitoramento das Águas Superficiais, principalmente por motivos de inúmeras modificações que ocorre na rede como a ampliação do número de pontos de amostragem, adequação das frequências de coletas, incremento de novas variáveis de qualidade, outros (CRHi, 2009). 
Deste modo, a análise considera que o índice possui abrangência adequada somente no quesito tempo, e assim, apresenta parcialmente concordância com este critério.

\section{Custo}

Não se mantêm um indicador em longo prazo se o custo para a obtenção da informação for alto. Sua manutenção depende de recursos humanos, técnicos e financeiros. Como abordado pelo perito, considerando o fator custo, o IQA sofreu alterações na sua frequência de monitoramento, com todas as adaptações necessárias e adequadas que mantivesse sua qualidade com uma relação custo/benefício no mesmo nível.

Não existem bases de comparação dos custos deste índice, tais como: custo da rede de monitoramento deste e de outros índices, etc. Contudo, considerando o elevado histórico deste, bem como as adaptações do mesmo para sua manutenção, observa-se que, para a SMA, este índice apresenta atualmente um custo/benefício favorável.

Desta forma, este histórico e principalmente o posicionamento apresentado pelo perito sobre a eficiência da adaptação do indicador no que tange o seu monitoramento para a manutenção de sua viabilidade tal critério é considerado um ponto forte deste índice.

\subsection{Considerações sobre a análise}

Os indicadores, dentro de uma função de apoio à política pública que norteie a sustentabilidade, devem ser elaborados num formato que forneçam bases sólidas para a tomada de decisão, contribuindo com a integração do meio ambiente com os componentes econômico-sociais.

As discussões sobre os pontos fortes e fracos dos indicadores ambientais têm como finalidade verificar a capacidade de tais indicadores em embasar tomadas de decisão que respondam aos questionamentos da sustentabilidade na esfera das políticas públicas.

Os indicadores ambientais inseridos na visão de sustentabilidade não devem contemplar apenas as funções técnicas de mensuração e operação (derivações) de parâmetros. Pelo contrário, tais indicadores devem ter a capacidade de auxiliar na compreensão e reflexão sobre impactos e objetos avaliados, traduzir o estado do meio ambiente de forma que possibilite a informação e principalmente que apoie a tomada de decisão.

Para tanto, os indicadores devem ser constituídos segundo princípios de boas práticas que verifiquem esta propriedade, ou seja, devem ter a capacidade de retratar estes princípios para que sejam capazes de cumprir a função de apoio às políticas públicas rumo à sustentabilidade. 
Os critérios de análise aplicados pela pesquisa foram desenhados justamente com vistas a verificar a capacidade dos indicadores de refletirem a estes princípios de boas práticas. Neste sentido, o que se observa pela aplicação dos critérios são os pontos fortes e fracos dos indicadores em contribuir às discussões sobre a sustentabilidade contribuindo na formulação e avaliação de políticas públicas.

Neste sentido, o método, por meio da aplicação ao IQA, se mostrou capaz de discutir a aptidão de tais indicadores em refletir as preocupações sobre a sustentabilidade do etanol de cana-de-açúcar no Estado de São Paulo, permitindo avaliar a adequação do índice neste novo contexto de sustentabilidade.

Como observado na Tabela 6.1 e explicado ao longo da seção 6.6 da pesquisa, o IQA apresenta cinco pontos fracos e apenas três pontos fortes em relação aos 11 critérios de análise empregados. Os demais pontos foram considerados parciais, isto é, apresenta pontos fortes e fracos para o mesmo critério.

Tal cenário mostra que o IQA está distante da visão empregada sobre o que espera-se de um indicador ambiental adequado para a discussão de sustentabilidade do etanol de canade-açúcar no Estado de São Paulo, sendo que sua utilização se tornaria mais efetiva caso os pontos fracos fossem trabalhados.

Para verificar mais claramente as informações apresentadas dentro da análise do índice a pesquisa recorreu a um arranjo estruturado por meio de uma análise SWOT, a qual está apresentada na sessão seguinte.

\subsection{SWOT}

A Swot é uma análise utilizada principalmente com o objetivo de prover os decisores com informações relacionadas a fatores importantes de uma determinada situação, tendo como produto a redução das incertezas e formulação de estratégias. (MARCELINO, 2004)

Assim, a análise SWOT corresponde à identificação e integração dos principais aspectos que caracterizam uma posição estratégica num determinado momento, tanto âmbito interno como externo (FUSCALDI; MARCELINO, 2008).

\subsubsection{Cenário, Políticas Públicas e tomada de decisão}

A evolução histórica do etanol de cana-de-açúcar demonstra que esta atividade apresenta tendências de elevado crescimento ao longo dos próximos anos, o que é uma perspectiva apoiada pela política energética nacional presente tanto no Plano Nacional de 
Energia - cenário 2030 (MME, 2010c), quanto na perspectiva da Matriz Energética Nacional - cenário 2030 (MME, 2007).

$\mathrm{O}$ incentivo ao etanol, bem como os impactos relacionados à atividade nos componentes sociais e em especial nos componentes ambientais (água, solo e ar apresentados no capítulo 5 da pesquisa) faz com que os agentes responsáveis pelas políticas públicas de meio ambiente, tanto nível federal, quanto estadual e municipal, sejam obrigados a lançarem mão de instrumentos de planejamento e gestão que sejam eficientes para condução da atividade rumo à sustentabilidade.

Esta perspectiva torna interessante e necessária a avaliação dos instrumentos destinados à formulação de políticas públicas relacionadas ao componente ambiental por parte de seu órgão responsável no Estado de São Paulo, qual seja a SMA.

Desta forma, os indicadores ambientais no contexto do etanol de cana-de-açúcar no Estado de São Paulo devem ter como uma de suas propriedades a capacidade de responder a esta demanda da SMA/SP, qual seja, servir de suporte e direcionador para a formulação de políticas públicas sustentáveis para o setor.

Por meio da análise SWOT dos indicadores produzidos e utilizados pela SMA/SP é possível verificar, com vistas aos seus objetivos e missão, a acuidade com que estes indicadores informam sobre a habilidade e sobre os planejamentos em políticas públicas para o etanol de cana-de-açúcar no Estado.

Considerando o conteúdo obtido a partir da oficina de discussão, bem como às consultas aos especialistas, a presente pesquisa traz adicionalmente a avaliação, por meio de uma SWOT de um dos principais indicadores da SMA/SP, qual seja o IQA - Índice de Qualidade de Água, demonstrando a estrutura segundo a qual os indicadores devem ser avaliados para composição de uma política pública que, respondendo aos critérios levantados, seja capaz de conduzir a atividade rumo à sustentabilidade.

Esta análise é apresentada por meio de uma matriz que compara os critérios analisados de indicadores (apresentados anteriormente) com os aspectos relacionados às oportunidades e ameaças presentes no cenário estratégico descrito pela pesquisa para a SMA/SP.

Espera-se que, por meio desta análise, seja possível apresentar um quadro de referência para a avaliação do conjunto de indicadores empregados pela SMA/SP, garantindo informações úteis à tomada de decisão e formulação de políticas públicas no que tange a atividade do etanol de cana-de-açúcar, bem como a formulação e utilização de indicadores ambientais para este propósito. 


\subsubsection{Aplicação e considerações sobre a SWOT}

De uma forma geral, na sessão anterior já haviam sido colocadas as forças e fraquezas do índice de qualidade da água. Para realização da SWOT resta então o levantamento das oportunidades e ameaças no emprego deste índice para o contexto analisado.

As oportunidades identificadas para emprego do IQA no setor sucroalcooleiro foram:

- Melhoria na rede de monitoramento: Através da melhoria do monitoramento (seja pela colocação de novos pontos ou mesmo pelo emprego de novas tecnologias de monitoramento) o índice teria resultados mais confiáveis.

- Melhoria da fiscalização: Caso haja melhoria na fiscalização o IQA tem a oportunidade de ganhar em Status na política pública de gestão sucroenergética.

- Aumento da intolerância aos impactos: caso haja uma elevação na intolerância da sociedade sobre os impactos do etanol no componente água o IQA pode ser mais bem aplicado/visto.

- Capacidade Institucional: Pela elevação do nível da capacidade institucional (recursos tecnológicos, humanos, integração institucional, etc) o IQA pode ter um ganho no emprego para o etanol.

Com a mesma sistemática, foram identificadas, como ameaças ao emprego do índice no contexto do etanol questões como:

- Mudança na tecnologia sucroalcooleira: podem invalidar os parâmetros considerados pelo indicador, tornando importantes outros parâmetros não analisados.

- Produção de índices mais robustos/potentes: Índices mais robustos podem fazer com que o IQA caia em desuso.

- Insuficiência de recursos/restrições orçamentárias: Caso haja uma elevação no custo do índice, é possível que por insuficiência de recursos não haja a possibilidade de emprego adequado do índice.

- Mudança na legislação: Caso a legislação imponha a obrigatoriedade de consideração de parâmetros não incorporados no IQA o mesmo se torna inútil.

Seguindo o método apresentado por Marcelino (2008) a pesquisa atribuiu pontuações nas relações observadas entre os pontos fortes e fracos e suas respectivas oportunidades e ameaças. 
A pontuação foi atribuída seguindo indicações (informações) das entrevistas, bem como análise teórica do índice, utilizando pesos de 1 a 3, sendo considerado 1 para questões de pouca significância, 2 para questões significativas e 3 para muito significativa. Os resultados estão organizados na Tabela 6.3.

A determinação do valor de referência ( 1 a 3 ) apresentado na Tabela 6.3 é proveniente da relação entre as oportunidades de melhoria e ameaças listadas na sessão anterior aos respectivos pontos fortes e fracos levantados.

As oportunidades e ameaças são, na prática, cenários que têm capacidade de influenciar a eficiência (qualidade) do indicador no apoio ao planejamento, implementação e avaliação de políticas públicas pela SMA no que tange o etanol de cana-de-açúcar.

Para melhor compreensão do trabalho realizado (SWOT) é interessante recorrer à exemplificação de uma das pontuações atribuídas, no caso, a pontuação atribuída à relação entre o ponto forte "Series Temporais" e a oportunidade de "Melhoria na rede de monitoramento".

Segundo as indicações apontadas pelo perito entrevistado sobre o IQA, o critério séries temporais é considerado um ponto forte do indicador por ter propriedades interessantes para análise, tais como confiabilidade nas séries pela utilização de pontos fixos de análise, histórico de longo prazo, dentre outros.

Como observado nos RQAs a densidade da rede de monitoramento do IQA é superior à indicada pela União Europeia, contudo, esta rede não está distribuída uniformemente estando concentrada nas regiões de maior densidade populacional.

Ainda segundo os RQAs, esta rede conta com monitoramentos automáticos e manuais.

Desta forma, melhorias na rede de monitoramento, tanto em termos de tecnologia, quanto e principalmente em termos de melhoria na distribuição desta rede no Estado podem potencializar fortemente o emprego deste indicador em políticas públicas sobre o etanol no que concerne às séries temporais.

Tal potencialização é evidenciada uma vez que esta rede estaria monitorando áreas onde a atividade é concentrada ou vem apresentando crescimento significativo, as quais não necessariamente têm maior densidade populacional.

Neste sentido os dados coletados pela rede formariam uma série com potencial de emprego para estas regiões, uma vez que os dados obtidos ganham força para composição de análises, permitindo a avaliação de tendências e informação para a tomada de decisão.

Com base nesta constatação é atribuída a pontuação 3 para esta relação. 


\begin{tabular}{|c|c|c|c|c|c|c|c|c|c|c|c|c|c|c|c|c|}
\hline \multirow[b]{2}{*}{ IQA } & \multicolumn{6}{|c|}{ FORTES } & & \multicolumn{8}{|c|}{ FRACOS } & \\
\hline & 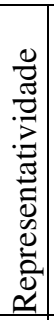 & 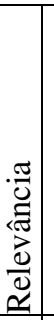 & 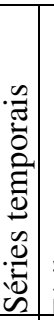 & 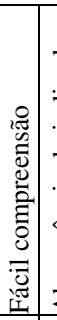 & 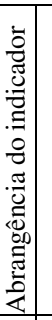 & $\begin{array}{c}\stackrel{0}{\mathscr{5}} \\
\stackrel{5}{\Xi} \\
\end{array}$ & 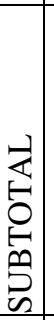 & 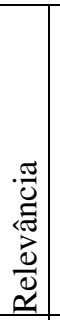 & 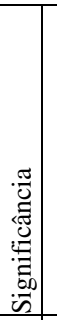 & 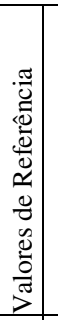 & 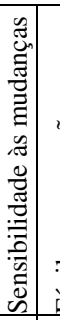 & 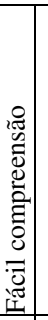 & 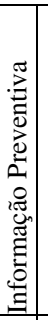 & 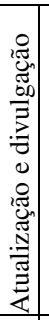 & 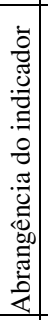 & 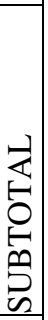 \\
\hline d Melhoria na rede de monitoramento & 1 & 1 & 3 & 1 & 3 & 3 & 12 & 2 & 1 & 2 & 3 & 1 & 3 & 2 & 3 & 14 \\
\hline Melhoria da fiscalização & 3 & 1 & 2 & 1 & 2 & 3 & 12 & 2 & 1 & 2 & 3 & 1 & 3 & 1 & 3 & 13 \\
\hline Aumento da intolerância aos impactos & 1 & 3 & 1 & 1 & 1 & 2 & 9 & 3 & 1 & 3 & 1 & 1 & 1 & 2 & 1 & 9 \\
\hline ô Capacidade Institucional & 1 & 2 & 3 & 3 & 3 & 3 & 15 & 2 & 1 & 2 & 3 & 3 & 2 & 3 & 3 & 16 \\
\hline SUBTOTAL & 6 & 7 & 9 & 6 & 9 & 11 & 48 & 9 & 4 & 9 & 10 & 6 & 9 & 8 & 10 & 65 \\
\hline Mudança na tecnologia sucroalcooleira & 3 & 3 & 1 & 1 & 1 & 1 & 10 & 3 & 3 & 3 & 1 & 1 & 3 & 1 & 2 & 11 \\
\hline Produção de índices mais robustos/potentes & 3 & 3 & 1 & 1 & 2 & 2 & 12 & 3 & 3 & 1 & 1 & 1 & 1 & 3 & 2 & 9 \\
\hline Insuficiência de recursos/restrições orçamentárias & 1 & 1 & 3 & 2 & 3 & 3 & 13 & 2 & 3 & 2 & 2 & 3 & 3 & 3 & 3 & 16 \\
\hline Mudança na legislação & 2 & 3 & 1 & 2 & 3 & 2 & 13 & 3 & 3 & 3 & 2 & 2 & 3 & 3 & 3 & 16 \\
\hline SUBTOTAL & 9 & 10 & 6 & 6 & 9 & 8 & 48 & 11 & 12 & 9 & 6 & 7 & 10 & 10 & 10 & 75 \\
\hline $\begin{array}{l}\text { Quadrante Q1-Potencial ofensivo } \\
\text { Quadrante Q2-Potencial defensivo } \\
\text { Quadrante Q3-Debilidade ofensiva } \\
\text { Quadrante Q4-Vulnerabilidade }\end{array}$ & & & & & & & & & & & & & & & & \\
\hline
\end{tabular}

A avaliação por quadrantes é um método que, segundo Marcelino (2008), permite uma visão geral sobre o quadro estratégico de vulnerabilidades, debilidades ofensivas, bem como de potencial ofensivo e defensivo do indicador analisado. Estes quadrantes (destacados na Tabela 6.3) são provenientes da soma das pontuações atribuídas a cada uma das relações entre pontos fortes e fracos, oportunidades e ameaças. (MARCELINO, 2008).

De acordo com o autor, o índice de vulnerabilidade é proveniente da soma dos pontos fracos e das ameaças, já o índice de debilidade ofensiva é mensurado pela soma dos pontos fracos e oportunidades. No caso do índice de potencial ofensivo seu resultado é proveniente da soma dos pontos fortes com as oportunidades, enquanto o índice de potencial defensivo é adquirido a partir da soma dos pontos fortes com as ameaças. Extraindo os dados da Tabela 6.3 e considerando os quadrantes segundo uma ordem crescente da esquerda para a direita é possível apresentar a tabela:

Tabela 6.4- Análise de quadrantes

\begin{tabular}{|c|c|c|}
\hline QUADRANTE & ÍNDICE & RESULTADO \\
\hline Q1 & Potencial ofensivo & 48 \\
\hline Q2 & Potencial defensivo & 48 \\
\hline Q3 & Debilidade ofensiva & 65 \\
\hline Q4 & Vulnerabilidade & 75 \\
\hline
\end{tabular}


Como apresentado por Marcelino (2008) o Potencial ofensivo aponta um elenco de oportunidades que confrontados com os pontos fortes identificam cenário bastante otimista, enquanto o potencial defensivo aponta para um confronto entre as ameaças identificadas no ambiente com as mesmas qualidades reconhecidas como pontos fortes, tornando-se suficiente para minimizar ou neutralizar estas ameaças.

Pela avaliação dos resultados observa-se bom potencial ofensivo e defensivo com $67 \%$ de potencial para ambos os casos, já que o resultado máximo possível para estes quadrantes segundo a análise seria de 72 pontos.

Já no que tange a debilidade ofensiva, de acordo com Marcelino (2008), este quadrante expressa o quanto os impactos negativos podem restringir o aproveitamento de oportunidades. De forma paralela, o grau de vulnerabilidade apresenta a ausência de elementos internos que absorvam o impacto das ameaças.

Em ambos os casos os valores possíveis eram 96. No caso da debilidade ofensiva o valor atribuído pela análise foi 65 , ou seja, $67 \%$ de debilidade ofensiva, enquanto no caso da vulnerabilidade o valor atribuído pela análise foi de 75 dos 96 possíveis.

Entende-se que, por tais resultados, a vulnerabilidade do IQA para responder às questões tratadas pelos critérios levantados sobre sustentabilidade do etanol de cana-deaçúcar, se mostra bastante elevada, sendo interessantes tais resultados para compor estratégias para avaliação ou mesmo emprego deste índice em políticas públicas.

Por fim, é importante considerar que este método pode ser aplicado a qualquer indicador, ou grupo de indicadores, sendo válido para apoio à gestão e análise. 


\section{CONSIDERAÇÕES FINAIS}

O cenário no qual se discute o tema sustentabilidade é constantemente modificado em função de alterações sobre entendimentos relacionados a cada uma de suas dimensões e dos componentes que às formam, o que, juntamente com a evolução das pesquisas e aumento da compreensão sobre os fenômenos observados nestas dimensões e componentes, faz com que o conceito evolua com o tempo.

Observa-se que dois dos principais produtos desta evolução são, respectivamente, o progresso na conscientização ambiental e o emprego do conceito de sustentabilidade em ações e políticas por meio de debates e conferências, bem como nas tentativas de conciliação de objetivos econômicos, demandas sociais e qualidade ambiental.

Para que ocorram expressivos incrementos nestas discussões, bem como ocorra à promoção de ações efetivas, embasando futuras discussões e tomadas de decisão mais concretas na busca pelo desenvolvimento sustentável é necessário que as informações disponíveis cumpram seu importante papel de promover o conhecimento e a sensibilização dos diversos atores na busca pela sustentabilidade.

Disponibilizar tais informações aos diversos usuários de forma a garantir a comunicação do conhecimento e a conscientização é a função primordial dos indicadores.

Observa-se que após a Conferência das Nações Unidas sobre o Meio Ambiente e Desenvolvimento no Rio de Janeiro, foram feitas muitas tentativas em desenvolver indicadores considerando o olhar do conceito de sustentabilidade e, portanto nos preceitos trazidos pela Agenda 21.

Estas tentativas anseiam conseguir ferramentas capazes de alcançar a nova proposta de desenvolvimento sustentável, elaborada sob uma forma conciliatória que busca contornar resistências à sua aplicação nas políticas de desenvolvimento, trazendo também uma nova perspectiva, bem como integrando novos componentes para sua discussão, tais como: justiça social, governança, dentre outros.

A integração do meio ambiente à formulação de políticas ganha destaque neste sentido, fazendo com que sejam necessárias ferramentas de possibilitem tal agregação.

Os indicadores são estas ferramentas, valiosas e úteis para tomada de decisão e no desenvolvimento de políticas sustentáveis.

Considerada como uma união sistêmica de diversos componentes, dentre os quais um deles é o ambiental, a sustentabilidade deve considerar as relações entre os diversos elementos que formam seu sistema. Desta forma, evidencia-se a importância direta dos componentes da 
dimensão ambiental considerados na pesquisa (componentes: água, solo e ar) como parte integrante da sustentabilidade.

A utilização de indicadores ambientais deve permitir a análise das condições, mudanças da qualidade ambiental e favorecer o entendimento das interfaces da sustentabilidade, possibilitando inclusive a apresentação de tendências, como uma ferramenta de suporte no processo de tomada de decisão e formulação de políticas e práticas sustentáveis.

Por estes motivos que esta pesquisa buscou propor uma estrutura de análise estratégica que evidenciasse pontos fortes e fracos de indicadores ambientais frente aos preceitos da sustentabilidade e princípios de boas práticas na elaboração e uso de tais indicadores.

Durante o processo de levantamento destes princípios para apoio à sustentabilidade foram encontradas muitas definições, sobreposições conceituais e interpretações de acordo com as distintas experiências. Neste sentido, de acordo com o consenso formado para cada experiência particular, os princípios podem ter maior ou menor relevância, bem como diferentes interpretações.

Para verificação destas questões o caso analisado expôs o debate sobre a sustentabilidade do etanol de cana-de-açúcar, considerando os indicadores ambientais da Secretaria do Meio Ambiente do Estado de São Paulo.

O objetivo desta análise foi ao mesmo tempo em que fornecer um contexto para o debate dos princípios de boas práticas na formulação e uso de indicadores ambientais para o desenvolvimento sustentável, expor uma metodologia para tal análise, considerando uma discussão teórica sobre o método de avaliação.

Essa estrutura ou método de análise buscou contribuir com as discussões acerca da sustentabilidade do etanol de cana-de-açúcar, ao direcionar de maneira embasada a formação de um conjunto de indicadores ambientais que sirva, juntamente com as discussões das demais dimensões componentes da sustentabilidade, de sustentáculo para políticas públicas voltadas para a sustentabilidade desta atividade, valendo-se dos critérios de boas práticas para tanto.

Tais princípios foram listados e discutidos com vistas aos conceitos de sustentabilidade levantados e aos impactos negativos considerados significativos das atividades de produção e consumo do etanol de cana-de-açúcar, sendo estes impactos significativos selecionados por uma saturação teórica que considerou a cadeia causal dos impactos apresentada no Quadro 6.3, a qual foi validada por especialistas ambientais (água, solo e ar) por meio de consultas diretas. 
Com base neste cenário foi proposta uma análise estratégica dos indicadores ambientais para a adequabilidade de tais indicadores frente aos preceitos da sustentabilidade, do que se espera de um indicador ideal para apoiar a tomada de decisão e informar a população sobre a qualidade do meio ambiente.

Esta busca é justificada pela importância de apontar indicadores ambientais a serem considerados adequados para o processo de avaliação e fomento de melhores políticas e práticas sustentáveis, ampliando o acesso às informações ambientais e suas interfaces com as questões sociais e econômicas, favorecendo a participação das partes interessadas nos processos de tomada de decisão, o que contribui para a consolidação do desenvolvimento em bases duradouras.

No que tange ao contexto do etanol, tal questão se mostra importante considerando sua escala de produção e expansão (tendência) principalmente pelos questionamentos sobre a sustentabilidade da atividade tanto da comunidade nacional quanto internacional, em especial no que tange o bioetanol enquanto fonte energética sustentável, dados os impactos evidenciados na pesquisa, em especial sobre o uso intensivo de solos e recursos naturais e o emprego de fertirrigação e agroquímicos, entre outros discutidos no capítulo 5.

De fato, dentro do contexto histórico da atividade não se observam preocupações com aspectos sociais e ambientais relacionados à mesma que motivassem discussões sobre políticas e gestão do setor, sendo que nos dias atuais a discussão da sustentabilidade para o etanol tem se concentrado na utilização de sistemas de certificação como mecanismos para fomento da comercialização destes produtos.

Face ao âmbito do presente trabalho, a proposta de mapeamento e de análise de indicadores ambientais frente à discussão da sustentabilidade do etanol se mostra importante, uma vez que ao se discutir a sustentabilidade de uma atividade se faz necessária a existência de indicadores ambientais que consigam cobrir os impactos negativos mais relevantes e ainda, que estes garantam a qualidade do processo de coleta, processamento, avaliação e comunicação da informação sobre o desempenho ambiental e da sustentabilidade, sendo esta análise suportada por um processo participativo.

A presente proposta metodológica reuniu em um mesmo plano a utilização de levantamentos bibliográficos, documentais e dos conhecimentos teóricos e práticos de especialistas e técnicos em indicadores, componentes ambientais e de sustentabilidade para conduzir a um contexto comum sobre a consolidação de critérios de boas práticas, bem como da utilidade do emprego dos indicadores presentes na SMA/SP para cobrir, segundo os critérios de boas práticas, os impactos considerados. 
O envolvimento de especialistas, por meio da Oficina de discussão, na elaboração dos critérios se tornou essencial para garantir efetivação e eficácia na sua aplicação. Isto aconteceu especialmente pela quantidade de princípios de boas práticas observados na literatura e suas varias peculiaridades e ambiguidades, ainda havendo a ausência de procedimentos que guiassem uma forma de utilização cabível para o estudo de caso.

Outra ressalva é relacionada às entrevistas. Apesar destas apresentarem certa limitação ao se basearem em informações referentes à percepção do entrevistado sobre o problema, a entrevista ou consulta permitiu por parte do pesquisador, controle sobre omissões de respostas ou interpretações distorcidas e por isto se mostrou um método válido.

O reconhecimento da complexidade em constituir um conjunto de indicadores de sustentabilidade voltados à discussão do ciclo de vida do etanol constitui um importante desafio.

A elaboração dos procedimentos metodológicos foi desenhada de acordo com o conhecimento adquirido pelo o estudo da literatura somado a contribuição dos especialistas. Portanto, esta estrutura foi sendo elaborada e lapidada de acordo com as indicações e com a evolução proporcionada pelas mesmas.

Tal estrutura foi discutida e validada por estes especialistas (entrevistas e oficina) e se demonstrou eficaz na sua aplicação, podendo ser usada no papel de guia metodológico por futuros trabalhos com objetivos semelhantes. Neste sentido seu formato é apresentado (Figura 7.1) de maneira genérica, para que possibilite esta intenção.

O conjunto de métodos produzidos foi empregado no IQA-SMA/SP - Indice de Qualidade do Ar da Secretaria do Meio Ambiente do Estado de São Paulo como forma ilustrativa de seu emprego.

O resultado de tal emprego demonstrou que o IQA se mostra frágil sobre os aspectos que se espera de um indicador capaz de apoiar a discussão de sustentabilidade, uma vez que o mesmo não demonstra poucas ligações com os elementos de sustentabilidade tramados na pesquisa, isto é para o contexto do etanol de cana-de-açúcar, como observado e discutido no capítulo 6 anteriormente apresentado.

Desta forma, a pesquisa entende ter seus objetivos alcançados, ao oferecer e discutir a adequação dos métodos para contribuir com a construção de um dos pilares essenciais ao desenvolvimento sustentável, o ambiental, e portando possibilitar que os indicadores ambientais alcancem o papel de instrumento fundamental e apropriado para suporte as tomadas de decisão, ações estratégicas e políticas no caminho a sustentabilidade. 


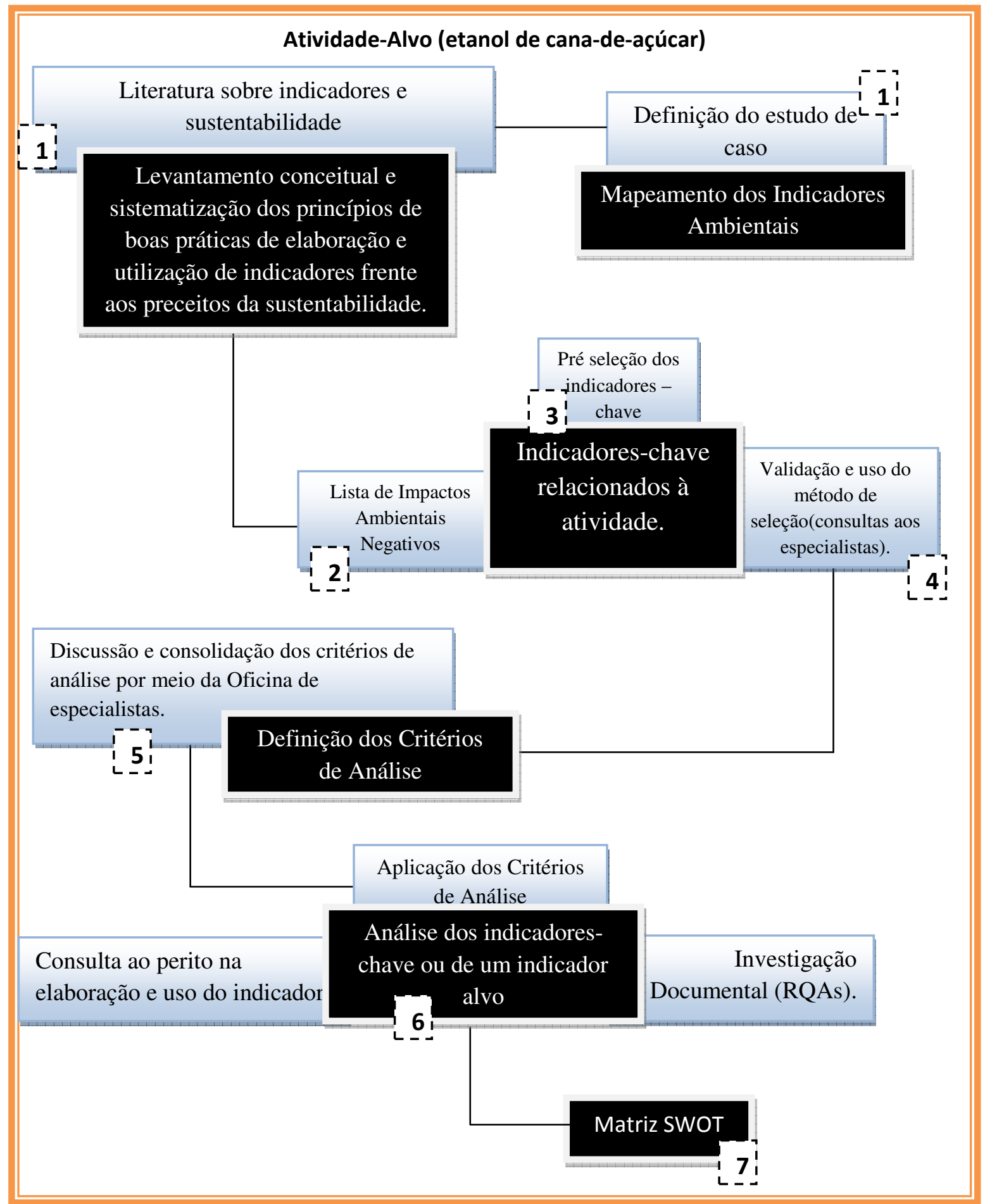

Figura 7.1- Estrutura de análise estratégica proposta

Porém tornam-se interessantes estudos que dêem continuidade na investigação de instrumentos e procedimentos que se coloquem aplicáveis e adequados para a análise de sustentabilidade e de monitoramento do desenvolvimento sustentável. 


\section{REFERÊNCIAS BIBLIOGRÁFICAS}

ABRANTES. J. S. (2003). Bio (sócio) diversidade e empreendedorismo ambiental na Amazônia. Brasilia: Garamond.

ACOS - Advisory Committee on Official Statistics. (2009). Good practice guidelines for the development and reporting of indicators. Wellington: Statistics New Zealand. Disponível em: http://www.statisticsnz.govt.nz/. Acesso em: 09 out 2010.

AGUIAR, D. A. (2009). Expansão da cana-de-açúcar no Estado de São Paulo: safras 2003/2004 a 2008/2009. In: SIMPOSIO BRASILEIRO DE SENSORIAMENTO REMOTO, 24., 2009, Natal. Anais... Natal: INPE, p. 9-16.

ANFAVEA - ASSOCIAÇÃO NACIONAL DE FABRICANTES DE VEÍCULOS AUTOMOTORES (2007).

Indústria Automobilística Brasileira: 50 Anos. 2007. Disponível em: <http://www.anfavea.co m.br/50anos/indice.pdf.> Acesso em: $21 \mathrm{dez} 2010$.

(2010). Anuário da Indústria Automobilística Brasileira: edição 2010. Disponível em: <http://anfavea2010.virapagina.com.br/anfavea2010/>. Acesso em: $27 \mathrm{dez} 2010$.

APHO - THE ASSOCIATION OF PUBLIC HEALTH OBSERVATORIE. (2008). The Good Indicators

Guide: Understanding how to use and choose indicators. Disponível em:

http://www.apho.org.uk/resource/item.aspx?RID=44584. Acesso em: 01 nov 2010.

ARRIGONI, E. B. (2005). Defensivos (pesticidas e outros). In: MACEDO, I. C. et al. A Energia da cana-deaçúcar: doze estudos sobre a agroindústria da cana-de-açúcar no Brasil e a sua sustentabilidade. São Paulo: Berlendis \& Vertecchia, ÚNICA. Cap.8.

ANVISA - Agência Nacional de Vigilância Sanitária. (2008). Evolução do consumo de agrotóxicos no Brasil 2003-2007. Disponível em: <http://www.mmcbrasil.com.br/materiais/151009_consumo_agrotoxicos_br.pdf>. Acessado em: 04 nov de 2010.

BAKKES, J.A.; et al (1994). An overview of environmental indicators: state of the art and perspectives. Nairobi: United Nations Environment Programme (UNEP)/Dutch National Institute of Public Health and Environmental Protection (RIVM).

BINSWANGER. H. C. (1999). Fazendo a sustentabilidade funcionar. In: CAVALCANTI C. (Org.), Meio ambiente, desenvolvimento sustentável e políticas públicas. 2. ed., São Paulo: Cortez.

BONI, V.; QUARESMA, S. J. (2005). Aprendendo a entrevistar: como fazer entrevistas em Ciências Sociais. Revista Eletrônica dos Pós-Graduandos em Sociologia Política da UFSC, Santa Catarina, v. 2 n.1-3, p. 6880, jan.-/jul. Disponível em: www.emtese.ufsc.br. Acesso em: 04 ago. 2010.

BOSSEL, H. (1999). Indicators for sustainable development: theory, methods, applications: a report to Balaton Group. International Institute for Sustainable Development. Winnipeg, Manitoba, Canada, IISD, 124p.

BSI - BETTER SUGARCANE INITIATIVE (2010). Disponível em: <http://www.bettersuga rcane.org/>. Acesso em: 02/11/2010.

BRASIL. (1981). Lei no 6.938, de 31 de agosto de 1981. Dispõe sobre a Política Nacional do Meio Ambiente, seus fins e mecanismos de formulação e aplicação, e dá outras providências. Diário Oficial da União, Brasília, DF, n. 167, Seção I, p. 16.509, 02 set. 1981

(1986). RESOLUÇÃO CONAMA No 001, de 23 de janeiro de 1986. Estabelece as definições, as responsabilidades, os critérios básicos e as diretrizes gerais para uso e implementação da Avaliação do Impacto Ambiental como um dos instrumentos da Política Nacional do Meio Ambiente. Diário Oficial da União, Brasília, DF, 17 fev. 1986.

(1989). Lei $n^{\circ} 7.804$, de 18 de julho de 1989. Altera a Lei $n^{\circ}$ 6.938, de 31 de agosto de 1981, que dispõe sobre a Política Nacional do Meio Ambiente, seus fins e mecanismos de formulação e aplicação, a Lei nº 7.735, 
de 22 de fevereiro de 1989, a Lei nº 6.803, de 2 de junho de 1980, e dá outras providências. Diário Oficial da União, Brasília, DF, nº.137, Seção I, p. 12.026, 20 jul. 1989

(1990). Lei n ${ }^{\circ}$ 8.028, de 12 de abril de 1990. Dispõe sobre a organização da Presidência da República e dos Ministérios, e dá outras providências. Diário Oficial da União, Brasília, DF, n.21-A, Seção I, p. 7.096, 13 abr. 1990.

BRIASSOULIS, H. (2001). Sustainable development and its indicators: through a (planner's) glass darkly. Journal of Environmental Planning and Management, London, v.44, n. 3, p. 409-427, may.

CANELLAS, L. P. et al. (2007). Estoque e qualidade da matéria orgânica de um solo cultivado com cana-deaçúcar por longo tempo. Revista Brasileira de Ciência do Solo, Viçosa, v. 31, n. 2, mar./abr.

CAPPELLI, S. (org). (2007). Indicadores de aplicação e cumprimento da norma ambiental para ar, água e vegetação no Brasil. Santiago: CEPAL/Nações Unidas.

CAVALCANTI, C. (Org.) (1994). Desenvolvimento e natureza: estudos para uma sociedade sustentável. São Paulo: Cortez.

CCDRA - COMISSÃO DE COORDENAÇÃO E DESENVOLVIMENTO REGIONAL DO ALGARVE. (2004). Sistema de indicadores de desenvolvimento sustentável do Algarve. Faro: SIG.

CCGE- CENTRO DE GESTÃO E ESTUDOS ESTRATÉGICOS. (2009). Bioetanol combustível: uma oportunidade para o Brasil. Brasília: Centro de gestão e estudos estratégicos (CGEE), 536p.

CERQUEIRA LEITE, R. C. (2010) A estratégia brasileira para o etanol. In: CORTEZ, L. A. B. (Coord.) Bioetanol de cana-de-açúcar: P\&D para produtividade e sustentabilidade. São Paulo: Edgar Blücher, 1.ed.

CETESB - COMPANHIA AMBIENTAL DO ESTADO DE SÃO PAULO. [entre 2006 e 2011]. Histórico. Disponível em: <http://cetesb.sp.gov.br/institucional/institucional/52-Historico>. Acesso em: 10 jan. 2011.

(2005). Qualidade do ar no estado de São Paulo. São Paulo: Secretaria do Meio Ambiente do Estado de São Paulo. (Série relatórios 2008).

(2008b). Relatório de Qualidade das Águas Interiores do Estado de São Paulo. São Paulo: Secretaria de Meio Ambiente. Série Relatórios 2008.

(2009) A CETESB mudou, para melhor atender à população de São Paulo. Disponível em: <http://www.cetesb.sp.gov.br/nova_cetesb.asp>. Acesso em: 10 jan. 2011.

CINTRA, F.N.; ANDRADE, P.; ALVES, M.C.M. (2004). Avaliação dos reflexos do Protocolo de Kyoto no setor sucroalcooleiro. Disponível em: <http://www.cori.rei.unicamp.br>. Acesso em: 31 ago. 2004.

COELHO, S.T.; LORA, B.A.; GUARDABASSI, P.M. (2010) Aspectos ambientais da cadeia do etanol de cana-de-açúcar no Estado de São Paulo. In: CORTEZ, L. A. B. (Coord.) Bioetanol de cana-de-açúcar: P\&D para produtividade e sustentabilidade. São Paulo: Edgar Blücher, 1.ed.

CONAB - COMPANHIA NACIONAL DE ABASTECIMENTO. (2010). Acompanhamento da Sacra Brasileira, $3^{\circ}$ levantamento. Cana-de-açúcar dez/2009. Disponível em:<http://www.conab.gov.br/detalhe. php?c=4543\&t=2\#this $>$. Acesso em: $02 \mathrm{dez} 2010$.

CÓNSUL, J.M.D., et al (2004). Decomposição catalítica de óxidos de nitrogênio. Química Nova, São Paulo, v.27, n. 3, p. 432-440.

CRHi - Coordenadoria de Recursos Hídricos. (2009). Relatório de Situação de Recursos Hídricos do Estado de São Paulo. São Paulo: Secretaria de Meio Ambiente.

CSIRO - COMMONWEALTH SCIENTIFIC AND INDUSTRIAL RESEARCH ORGANISATION. (1999). A guidebook to environmental indicators. Disponível em: <http://www.csiro.au/csiro/envind/ code/pages/menu.htm>. Acesso em: $11 \mathrm{dez} .2008$. 
CSO - CENTRAL STATISTICAL OFFICE. (2008). Measuring Ireland's Progress 2007. Dublin: Stationary Office, 2008. Disponível em: <http://www.cso.ie/releasespublications/documents/other_releas es/2007/progress2007/measuringirelandsprogress.pdf>. Acessado em 24 ago de 2010.

CTC- CENTRO DE TECNOLOGIA CANAVIEIRA. (2009). Disponível em: http://www.ctc.com.br/. Acessado em: 23 mar. 2009.

DANZ, N. P., et al (2005). Environmentally stratified sampling design for the development of great lakes environmental indicators. Environmental Monitoring and Assessment, New York, n. 102, p. 41-65.

DELZEIT, R.; HOLM-MULLER, K. (2008). Steps to discern sustainability criteria for a certification scheme of bioethanol in Brazil: Approach and difficulties. Energy, Amsterdam, v. 34, p. 662-668.

DIAS, R. (2007). Gestão Ambiental: Responsabilidade Social e Sustentabilidade. São Paulo: Atlas.

DONZELLI, J.L. (2005). Preservação dos solos agrícolas. Capítulo 7. In: MACEDO, I. C. et al. A Energia da cana-de-açúcar: doze estudos sobre a agroindústria da cana-de-açúcar no Brasil e a sua sustentabilidade. São Paulo: Berlendis \& Vertecchia, Unica.

EEA - EUROPEAN ENVIRONMENT AGENCY. (1999). Environmental indicators: typology and overview. Copenhagen: EEA. (Technical report, n.25).

(2003). Environmental Indicators: typology and Use in Reporting. EEA, 2003. Disponível em: $<$ http://www.brahmatwinn.unijena.de/fileadmin/Geoinformatik/projekte/brahmatwinn/Workshops/FEEM/Indicat ors/EEA_Working_paper_DPSIR.pdf.>. Acesso em: 23 jun. 2010.

ELIA NETO, A.; NAKAHODO, T. (1995). Caracterização físico-química da vinhaça. Piracicaba: Centro de Tecnologia Canavieira.

EPA - ENVIRONMENTAL PROTECTION AGENCY. WASTES. (2010). Educational Materials. Disponível em: <http://www.epa.gov/waste/education/quest/gloss1a.htm>. Acesso em: 17 dez. 2010.

ESTY, D. C.; et al. (2005). Environmental Sustainability Index: benchmarking national environmental stewardship. New Haven: Yale Center for Environmental Law \& Policy.

EUROSTAT - STATISTICAL OFFICE OF THE EUROPEAN COMMUNITIES. (2004). EU member state experiences with sustainable development. Disponível em: <http://epp.eurostat. ec.europa.eu/cache/ITY_OFFPUB/KS-AU-04-001/EN/KS-AU-04-001-EN.PDF>. Acesso em: 20 jul. 2008.

FERNANDEZ, F. (2005). Aprendendo a lição de Chaco Canyon: do desenvolvimento a uma vida sustentável. Revista Reflexão, São Paulo, v 6, n. 15, p. 13-19, ago.

FURRIELA, R. B. (2002). Democracia, cidadania e meio ambiente. São Paulo: Annablume / Fapesp.

FUSCALDI, K. C.; MARCELINO, G. F. (2008). Análise Swot: O caso da Secretaria de Política Agrícola. (Anais). Congresso da Sociedade Brasileira de Economia, Administração e Sociologia Rural. 6, Rio Branco: SOBER.

GABRIEL FILHO, A. (1993). Influência da variação de algumas propriedades físicas do solo no desenvolvimento de plantas de eucalipto (Eucaliptus grandis). $100 \mathrm{f}$. Dissertação (Mestrado). Faculdade de Ciências Agrárias, Universidade Estadual Paulista Julio de Mesquita Filho, Botucatu, 1993.

GALLOPÍN, G. (1997). Indicators and their use: information for decision making. In: MOLDAN, B.; BILHARZ, S. Sustainability Indicators. Chichester: Scientific Committee On Problems of the Environment SCOPE (Report on the project on Indicators of Sustainable Development.).

GALLOPÍN, G. C. (2003). A systems approach to sustainability and sustainable development. Santiago: Ed. Cepal. (ONU- Serie Medio Ambiente e Desarrollo n. 64). 
GARCIA, J. C.; SPERLING, E. V. (2010). Emissão de gases de efeito estufa no ciclo de vida do etanol: estimativa nas fases de agricultura e industrialização em Minas Gerais. Engenharia Sanitária e Ambiental, Rio de Janeiro, v. 15, n. 3, Set.

GIBSON, R. et al. (2005). Sustainability Assessment: criteria, processes and application. London, Sterling: Earthscan.

GIL, A.C. (2002). Como elaborar projetos de pesquisa. 4. ed. São Paulo: Atlas.

GOLDEMBERG; J.; LUCON, O. (2008). Energia, Meio Ambiente e Desenvolvimento. 3. ed. rev. ampl. São Paulo: Editora da Universidade de São Paulo.

GOMES, M. L.; MARCELINO, M. M.; ESPADA, M. (2000). Proposta para um sistema de indicadores de desenvolvimento sustentável. Portugal: Direção de Serviços de Informação e Acreditação/Direção Geral do Ambiente. 228 p. Disponível em: <http://www.iambiente.pt/sids/sids.pdf>. Acesso em: 12 nov. 2009.

GOMES, I. (2004). Sustentabilidade social e ambiental na agricultura familiar. Revista de Biologia e Ciências da Terra, Recife, v. 5, n.1.

GOMES, M. S. P.; ARAUJO, M. S. M. (2009). Bio-fuels production and the environmental indicators. Renewable and Sustainable Energy Reviews, Amsterdam, v. 13, p. 2201-2204.

GREMAUD, A. P.; VASCONCELLOS, M. A. S.; TONETO, R. (2005). Economia brasileira e contemporânea. 6. ed., São Paulo: Atlas.

GUIMARÃES' L. T.; TURETTA, A. P. D.; COUTINHO, H. L. C. (2010). Uma proposta para avaliar a sustentabilidade da expansão do cultivo da cana-de-açúcar no estado do Mato Grosso do Sul. Revista Sociedade e Natureza, Uberlândia, v.22, n.2, aug.

GUTIÉRREZ-ESPELETA, E. E. (1998). Designing Environmental Indicators for Decision makers. In: CONFERENCE OF THE INTERNATIONAL ASSOCIATION OF SURVEY STATISTICIAN AND THE INTERNATIONAL ASSOCIATION FOR OFFICIAL STATISTICS. México: Aguascalientes. Proceedings... México: INEGI - Instituto Nacional de Estadística, Geografía e Informática.

HAMMOND, A. et al. (1995). Environmental Indicators: a systematic approach to measuring and reporting on environmental policy performance in the context of sustainable development. Washington, D.C.: World Resources Institute.

HARDI, P.; ZDAN, T. (1997). Assessing Sustainable Development: Principles in Practice. Minnesota: Canadian Cataloguing in Publication Data. 166 p.

HEINK, U.; KOWARIK, I. (2010). What are indicators? On the definition of indicators in ecology and environmental planning. Environmental Indicator, Amsterdam, v.10, n. 3, p. 584-593, mai.

HELLER, L.; RIBEIRO, J. C. J. (2004). Indicadores ambientais para países em desenvolvimento. In: CONGRESO INTERAMERICANO DE INGENIERIA SANITARIA Y AMBIENTAL. 29., 2004. Proceedings... San Juan.

IBGE - INSTITUTO BRASILEIRO DE GEOGRAFIA E ESTATÍSTICA. (2004). Previsão e Acompanhamento de Safras nos Estados de São Paulo, Paraná, Santa Catarina e Distrito Federal. Disponível em: $<$ http://www.ibge.gov.br/home/estatistica/economia/agropecuaria/estatisticas_previsao_safras/Previsao_safras.p df>. Acesso em: 08 mar. 2010.

IPCC-NGGIP. (2006). Guidlines for national greenhouse gas inventories: 2006. Disponível em: <http://www.ipccnggi.iges.or.jp/public/2006gl>. Acesso em: 15 jan. 2009.

IPEA - INSTITUTO DE PESQUISA ECONÔMICA APLICADA. (2007). Objetivos de desenvolvimento do milênio: relatório nacional de acompanhamento. Disponível em: <http://www.ipea.gov.br/sites/000/2/ download/TerceiroRelatorioNacionalODM.pdf>. Acesso em: 07 jan. 2011. 
JATOBÁ, S.U.S.; CIDADE, L.C.F.; VARGAS, G.M. (2009). Ecologismo, Ambientalismo e Ecologia Política: diferentes visões da sustentabilidade e do território. Sociedade e Estado, Brasília, v.24, n.1, p. 47-87, jan-abr.

JESINGHAUS, J. (1999). Indicators for decision- making. European Commission: JRC/ISIS/MIA. Disponível em: <http://esl.jrc.it/e>. Acesso em: 23 dez. 2010.

JORGENSEN, S.E. (2005). Introduction. In: JORGENSEN, S.E.; COSTANZA, R.; XU, F.L. (Eds.). Handbook of ecological indicators for assessment of ecosystem health. New York: CRC Press Taylor \& Francis Group.

KHANNA, N. (2000). Measuring environmental quality: an index of pollution. Ecological Economics, Amsterdam, v. 35, n. 2, p. 191-202, nov.

KALTSCHMITT, M.; REINHARDT, G.A.; STELZER, T. (1997). Life cycle analysis of biofuels under different environmental aspects. Biomass and Bioenergy, Amsterdam, v. 12, n. 2, p. 121-134.

KATES, R.W.; PARRIS, T.H.; LEISEROWITZ, A.A. (2005). What is sustainable development? Goals, indicators, values and practice. Environment: Science and Policy for Sustainable Development, St.Louis, v.47, n.3, p.8-21, apr.

KHANNA, N. (2000). Measuring environmental quality: an index of pollution. Ecological Economics, Amsterdam, v. 35, n. 2, p. 191-202, nov.

LAKATOS, E. M.; MARCONI, M. A. (1992). Metodologia do trabalho científico: procedimentos básicos, pesquisa bibliográfica, projeto e relatório, publicações e trabalhos científicos. 4. ed. São Paulo: Atlas.

LÉLÉ, S. M. (1991). Sustainable Development: a critical review. World Development, Gredt Britain, v.19, n.6, p.607-621, jun.

LEMOS, H. M. (2007). As Normas ISO 14000. Instituto Brasil PNUMA. Disponível em:

$<$ http://www.brasilpnuma.org.br/pordentro/saibamais_iso14000.htm>. Acesso em: 15 fev. 2009.

LEWANDOWSKI, I.; FAAIJ, A.P.C. (2006). Steps towards the development of a certification system for sustainable bio-energy trade. Biomass and Bioenergy, Amsterdam, v. 30, n. 2, p. 83-104, fev.

LIMA, R. C. M. (2008). Informação para o desenvolvimento e a formação de recursos humanos e especializados. Rio de Janeiro: E-papers.

LUDWIG. V. S. (2004). Protocolo de Kyoto: compromisos incumplidos e instrumentos emergentes. Boletín Económico de ICE $n^{\circ}$ 2815. Set. 2004. Disponível em: <http://www.revistasice.info/cmsrevistas ICE/pdfs/BICE_2815_45-59_3CCEF71A454D80CF74EB8DC04101DAB4.pdf>. Acesso em: 23 dez. 2010.

MACEDO, I. C. et al. (2004). Balanço das emissões de gases do efeito estufa na produção e no uso do etanol no Brasil. São Paulo: Secretaria de Meio Ambiente do Estado de São Paulo.

MAGALHÃES JÚNIOR, A.P. (2007). Indicadores ambientais e recursos hídricos: realidade e perspectivas para o Brasil a partir da experiência francesa. Rio de Janeiro: Bertrand Brasil. 688p.

MALHEIROS, T. F.; PHILIPPI JR. A.; AGUIAR, A. O. (2005). Indicadores de desenvolvimento sustentável. In: PHILIPPI JR. A. Saneamento, saúde e ambiente: fundamentos para um desenvolvimento sustentável. Barueri: Manole.

MALHEIROS, T. F.; PHILIPPI JR., A.; COUTINHO, S. M. V. (2008). Agenda 21 nacional e indicadores de desenvolvimento sustentável: contexto brasileiro. Revista Saúde e Sociedade, São Paulo, v. 17, n. 1, p. 7-20, mar.

MANASSARAM, D. M.; BACKER, L. C.; MOLL D. M. (2007). A review of nitrates in drinking water: maternal exposure and adverse reproductive and developmental outcomes. Revista Ciência \& Saúde Coletiva, Rio de Janeiro, v.12, n.1, Jan./Mar. 
MARCELINO, G.F. (2004). Gestão Estratégica de Universidade: A constrição da FACE/UnB. Brasília: Universidade de Brasília, Faculdade de Administração, Contabilidade, Economia, Ciência da Informação e Documentação. 256p.

MARTINS FILHO, M. V. et al. (2009). Perdas de solo e nutrientes por erosão num Argissolo com resíduos vegetais de cana-de-açúcar. Revista de Engenharia Agrícola, Jaboticabal, v.29, n.1, Jan./Mar.

MARTÍNEZ, R.Q. (2009). Guía metodológica para desarrollar indicadores ambientales y de desarrollo sostenible en países de América Latina y el Caribe. Santiago do Chile: CEPAL.

MATOS, A. T. (1997). Manejo e conservação do solo. Rio de Janeiro: Campos Universidade do Norte Fluminense.

McGLADE, J. (2007). Foreword: Finding the Right Indicators for policymaking. In: HÁK, T.; MOLDAN, B.; DAHL, A.L. Sustainability Indicators: A scientific assessment. Washington: Island Press.

MEADOWS, D. (1998). Indicators and information systems for sustainable development. Hartland Four Corners: Sustainability Institute, 1998.

MME - MINISTÉRIO DE MINAS E ENERGIA. (2007). Matriz Energética Nacional 2030. Disponível em: $<$ http://www.mme.gov.br/spe/galerias/arquivos/Publicacoes/matriz_energetica_nacional_2030/Matriz EnergeticaNacional2030.pdf>. Acesso em: 21 nov. 2010.

(2010a). Balanço energético nacional 2010: Ano base 2009. Disponível em: <http://www.mme. gov.br/mme/menu/todas_publicacoes.html>. Acesso em: 14 set. 2010.

(2010b). Relatório anual de energia 2010. Ano Base 2009. Disponível em: <http://www.mme. gov.br/mme/menu/todas_publicacoes.html.> Acesso em: 14 nov. 2010.

(2010c) Plano Nacional de Energia 2030. Set. 2010. Disponível em: <http://www.mme.gov.br/ mme/galerias/arquivos/ publicações/pne_2030/8_Biomassa.pdf>. Acesso em: 21 nov. 2010.

MOLDAN, B. (1997). Decision-making cycle. In: MOLDAN, B; BILLHARZ. S. (Eds.) Sustainability indicators: report of the project on indicators of sustainable development. New York: John Wiley \& Sons.

MOLINA, N. S. (2010) Marketing ambiental e certificações socioambientais: uma análise no contexto do etanol brasileiro. Dissertação (Mestrado). 128 p. Escola de Engenharia de São Carlos - EESC, Universidade de São Paulo - USP, São Carlos.

MONTIBELLER-FILLHO, G. (2000). Apropriações diferenciadas do conceito de desenvolvimento sustentável. Geosul, Florianópolis, v.15, n 29, p. 44-54, jan/jun.

MOREIRA, I.V.D. (1988). EIA in Latin America. In: WATHERN, P. (Org.). Environmental impact assessment: theory and practice. London: Unwin Hyman, p. 239-253.

MUELLER, C.C. (1992). Situação atual da produção de informações sistemáticas sobre o meio ambiente. Ciência da Informação, Brasília, v.21, n.1, p.14-22, jan./abr.

MUNN, R.E. (1975). Environmental impact assessment: principles and procedures. SCOPE report 5. Toronto: John Wiley \& Sons.

NETO, A. E. (2005). Captação e uso de água no processamento de cana-de-açúcar. In: MACEDO, I C. et al. A Energia da cana-de-açúcar: doze estudos sobre a agroindústria da cana-de-açúcar no Brasil e a sua sustentabilidade. São Paulo: Berlendis \& Vertecchia, ÚNICA.

O’BRIEN, J. A. (2004). Sistemas de informação e as decisões gerenciais na era da internet. São Paulo: Saraiva. 
OECD - ORGANIZATION FOR ECONOMIC CO-OPERATION AND DEVELOPMENT. (1993). Core set of indicators for environmental performance reviews. Environment Monographs $\mathrm{N}^{\circ}$ 83. OECD. Disponível em: <http://www.nssd.net/pdf/gd93179.pdf>. Acesso em: 23 fev. 2010.

OLIVEIRA, M. W. et al (2002). Leaching of nitrogen, potassium, calcium and magnesium in a sandy soil cultivated with sugarcan. Revista Pesquisa Agropecuária Brasileira. vol.37 no.6 Brasília June 2002.

OMETTO, A.R.; MANGABEIRA, J.A.C.; HOTT, M.C. (2005). Mapeamento de potenciais de impactos ambientais da queima de cana-de-açúcar no Brasil. In: SIMPÓSIO BRASILEIRO DE SENSORIAMENTO REMOTO, 12., 2005, Goiânia. Anais... Goiânia: INPE, p. 2297-2299.

PIERRI, N. (2001). O processo histórico e teórico que conduz à proposta de desenvolvimento sustentável. In: PIERRI N.; FOLADORIO, G.(Eds). Sustentabilidad? Desacuerdos sobre el desarollo sostenible. Montevideo: Trabajo y Capital, 271p.

PIERZYNSKY, G.M.; SIMS, J.T.; VANCE, G.F. (2000). Soil and environmental quality. 2.ed. Boca Raton. PNUD - PROGRAMA DAS NAÇÕES UNIDAS PARA O DESENVOLVIMENTO. (ANO). Objetivos de desenvolvimento do milênio. Disponível em: <http://www.pnud.org.br/odm/>. Acesso em: 06 jan. 2011.

QUIROGA, R. Indicadores de sostenibilidad ambiental y desarollo sostenible: estado Del arte y perspectivas. n.16, Santiago: CEPAL, 2001.

RABINOVICH, J. E.; TORRES, F.(2004). Caracterización de los Síndromes de sostenibilidad del desarrollo: El caso de Argentina. Santiago: Cepal - ONU. (Serie Seminarios y conferencias n. 38).

REDCLIFT, M. R. (2007). Sustainable development (1987-2005) - an oxymoron comes of age. Horizontes Antropológicos, Porto Alegre, ano 12, n. 25, p. 65-84, jan./jun.

REED, M.S.; FRASER, E.D.G.; DOUGILL, A.J. (2006). An adaptive learning process for developing and applying sustainability indicators with local communities, Ecological Economics, Amsterdam, v. 59, p.406-418.

REES, W. (1992). Ecological footprints and appropriated carrying capacity: what urban economies leaves. Environment and Urbanization, Thousand Oaks, v. 4, n. 2, p. 121-130.

RIBEIRO, H. (2008). Queimadas de cana-de-açúcar no Brasil: efeitos à saúde respiratória. Revista Saúde Pública, São Paulo, v. 42, n. 2, abr. Disponível em: <http://www.scielo.br/>. Acesso em: 23 dez. 2010.

ROMEIRO A. R. (2003). Economia ou economia política da sustentabilidade. In MAY, P.H., LUSTOSA, M.C., VINHA V. (Orgs), Economia do Meio Ambiente: teoria e pratica. Rio de Janeiro: Elsevier.

ROSSETO, R.; SANTIAGO, A. D. (2010). Adubação: Resíduos e alternativas. Disponível em: <http://www.agencia.cnptia.embrapa.br/gestor/cana-de-acucar/arvore/CONTAG01397112005 16717.html>. Acesso em: 20 dez. 2010.

ROTMANS, J. (2006). Tools for integrated sustainability assessment: a two-track approach. The Integrated Assessment Journal, Vancouver, v. 6, n. 4, p. 35-57.

RSB - Roundtable on Sustainable Biofuels (2010). Disponível em: <http://rsb.epfl.ch/>. Acesso em: 26 de dez. 2010 .

RUDORFF, B. F. T. et al. (2009). Mapeamento da área cultivada com cana-de-açúcar no estado de São Paulo na safra 2007/2008 por meio de imagens de satélite de sensoriamento remoto. São José dos Campos: INPE.

SACHS, I. (1990). Desarrollo sustentable, bio-industrialización descentralizada y nuevas configuraciones ruralurbanas. Los casos de India y Brasil. Pensamiento Iberoamericano, Madrid, v. 46, p. 235-256.

SACHS, I. (1993). Estratégias de transição para o século XXI. São Paulo: Studio Nobel/Fundap. 
SACHS, I. (2002). Caminhos para o desenvolvimento sustentável. 2. ed. Rio de Janeiro: Garamond.

SÁNCHEZ, L.H. (2008). Avaliação de impacto ambiental: conceitos e métodos. São Paulo: Oficina de Textos, 495p.

SANTOS, R. F. (2004). Planejamento ambiental: teoria e prática. São Paulo: Oficina de Textos.

SÃO PAULO. (1973). Lei n ${ }^{\circ} 118$, de 29 de junho de 1973. Autoriza a constituição de uma sociedade por ações, sob a denominação de CETESB - Companhia Estadual de Tecnologia de Saneamento Básico e de Controle de Poluição das Águas, e dá providências correlatas. Diário Oficial do Estado, São Paulo, SP, 30 jun. 1973. pag. 3.

(1997). Lei no 9.509, de 20 de março de 1997. Dispõe sobre a Política Estadual do Meio Ambiente, seus fins e mecanismos de formulação e aplicação. Diário Oficial do Estado, São Paulo, SP,. n 55.

(2009a). Lei no 13.542 , de 8 de maio de 2009. Altera a denominação da Cetesb - Companhia de Tecnologia de Saneamento Ambiental e dá nova redação aos artigos $2^{\circ}$ e 10 da Lei no 118 , de 29 de junho de 1973. Diário Oficial do Estado, São Paulo, SP, 09 mai. 2009. n. 85, Seção I.

(2009b). Decreto n ${ }^{\circ}$ 54.653, de 6 de agosto de 2009. Reorganiza a Secretaria do Meio Ambiente - SMA e dá providências correlatas. Diário Oficial do Estado, São Paulo, SP, 07 ag. 2009. Seção I.

SATO, A. C. K. (1999). Índices de Sustentabilidade. Unicamp. Disponível em: <www.unicamp.br/fea/ortega/temas530/anacarla.htm>. Acesso em: 29 jul. 2008.

SAUNDERS, D.C.; MARGULES, C.; HILL, B. (1998). Environmental indicators for national state of the environment reporting-Biodiversity. Australia: State of the Environment (Environmental Indicator Reports).

SCORZA JÚNIOR, R. P. (2010). Comportamento ambiental de agrotóxicos em áreas com cana-de-açúcar. Embrapa Agropecuária Oeste Dourados. Disponível em: <www.agrosoft.org. br/agropag/212703.htm>. Acesso em: 29 set. 2010.

SMA - SECRETARIA DO MEIO AMBIENTE DO ESTADO DE SÃO PAULO. (2009). Disponível em: $<$ http://www.ambiente.sp.gov.br/>. Acesso em: 25 nov. 2009.

SHENG, F. (1999). Valores em mudança e construção de uma sociedade sustentável. In: CAVALCANTI C. (Org.), Meio Ambiente, desenvolvimento sustentável e políticas públicas. 2 ed. São Paulo: Cortez.

SHIELDS, D.; SOLAR, S.; MARTIN, W. (2002). The role of values and objectives in communicating indicators of sustainability. Ecological Indicator, Amsterdam, v. 2, n. 1-2, p. 149-160, nov. 2002.

SIBIS - STATISTICAL INDICATORS BENCHMARKING THE INFORMATION SOCIETY. (2003). New eEurope Indicator Handbook. European Comission. Disponível em: <http://www.sibis-eu.org/ files/Sibis_Indicator_Handbook.pdf>. Acesso em: 14 ago. 2010.

SICHE, R. (2007). Índices versus indicadores: precisões conceituais na discussão da sustentabilidade de países. Ambiente \& Sociedade, Campinas, v. 10, n. 2 p. 137-148 jul.-dez.

SILVA, V. L. M. M.; GOMES, W. C.; ALSINA, O. L. S. (2007). Utilização do bagaço de cana de açúcar como biomassa adsorvente na adsorção de poluentes orgânicos. Revista Eletrônica de Materiais e Processos. v. 2, $\mathrm{n}^{\circ}$ 1 p. 27-32.

SMEETS, E. et. al. (2008). The sustainability of Brazilian ethanol—An assessment of the possibilities of certified production. Biomas s and bioenergy, Amsterdam, v. 32, n. 8, p. $781-813$.

SOARES, L. H. B. et al. (2009). Mitigação das emissões de gases efeito estufa pelo uso de etanol da cana-deaçúcar produzido no Brasil. Brasília: Ministério da Agricultura, Pecuária e Abastecimento. (Circular Técnica, n.27).

SOUZA, M. P.(2000). Instrumentos de gestão ambiental: fundamentos e prática. São Carlos: Ed. Rima Costa. 
SOUZA, S. A. V. (2005). Vinhaça: o avanço das tecnologias de uso. In: MACEDO, I. C., et al. A Energia da cana-de-açúcar: doze estudos sobre a agroindústria da cana-de-açúcar no Brasil e a sua sustentabilidade. São Paulo: Berlendis \& Vertecchia, ÚNICA.

TAYRA, F. (2002). A relação entre o mundo do trabalho e o meio ambiente: limites para o desenvolvimento sustentável. Scripta Nova, Revista Electrónica de Geografía y Ciencias Sociales, Universidad de Barcelona, v. 6, n. 119, p. 72. Disponível em: <http://www.ub.es/geocrit/sn/sn119-72.htm > Acesso em: 28 jan. 2009.

TAYRA, F. (2006). Capital natural e graus de sustentabilidade: visões de mundo e objetivos conflitantes. Pensamento \& Realidade, Brasília, v.9, n.19. Disponível em: <http://www.faculdadesaoluis.br/downloa ds/pdf/revista/revista19.pdf\#page=100>. Acesso em: 28 jan. 2009.

THE WORLD BANK. (1997). Expanding the measure of wealth: indicators of environmentally sustainable development. Washington, D.C.: Editora. 110 p. (Environmentally sustainable development studies and monographs series, n.17).

(2006). INTERNATIONAL BANK FOR RECONSTRUCTION AND DEVELOPMENT. World

development indicators. Washington: World Bank. Disponível em: <http://devdata.worldbank.

org/wdi2006/contents/Partners. htm.> Acesso em: 12 fev. 2009.

TODOROV, V.I.; MARINOVA D. (2009). Models of sustainability. In: 18th World IMACS / MODSIM Congress, 18., 2009, Cairns, Australia. Proceedings... Austrália, Disponível em: <http://www.mssanz. org.au/modsim09/D2/todorov_D2a.pdf>. Acesso em: 03 jul. 2010.

TURNER, R. (1987). Sustainable global futures. Common interest, interdependency, complexity and global possibilities. Futures, Amsterdam, v.19, n.5, p. 574-582.

TURNHOUT, E.; HISSCHEMOLLER, M. y EIJSACKERS, H. (2007): Ecological indicators: between the two fires of science and policy. Ecological Indicators, v. 7, n 2. p. 215-228.

UGUCIONE, C., et al. (2002). Processos diurnos e noturnos de remoção de NO2 e NH3 atmosféricos na região de Araraquara. Eclética Química, Araraquara, v.27, n.special.

UNCED - UNITED NATIONS CONFERENCE ON ENVIRONMENT AND DEVELOPMENT. (1993).

Agenda 21: the earth summit strategy to save our planet. Rio de Janeiro: Ed. Boulder, Earthpress.

ÚNICA - UNIÃO DA AGROINDÚSTRIA CANAVIEIRA. (2010a). Sustentabilidade e meio ambiente. Disponível em: $<$ http://www.ÚNICA.com.br/content/show.asp?cntCode $=\{0$ C8534A8-74A7-495 2- 8280C5F6FB9276B7\}> Acesso em: 02 jan. 2011.

(2010b). Dados e Cotações - Estatísticas. Produção de cana-de-açúcar do Brasil. 2010. Disponível em: <http://www.ÚNICA.com.br/dadosCotacao/estatistica/>. Acesso em: 13 dez. 2010.

(2010c). Dados e Cotações - Estatísticas. Produção de etanol do Brasil. 2010. Disponível em: $<$ http://www.ÚNICA.com.br/dadosCotacao/estatistica/>. Acesso em: 26 nov. 2010.

(2010d). Ranking da produção de cana, açúcar e etanol das unidades da Região Centro-Sul. Safra 2008/09. 2010. Disponível em: <http://www.ÚNICA.com.br/ dadosCotacao/estatistica/>. Acesso em: $22 \mathrm{dez}$. 2010.

VAN BELLEN, H.M.(2005). Indicadores de sustentabilidade: uma análise comparativa. Rio de Janeiro: FGV.

VEIGA, J. E. (2005) Desenvolvimento Sustentável: o desafio do século XXI. Rio de Janeiro: Garamond.

VEIGA FILHO, A. de A. (2007). Novo ciclo do Proálcool: problemas derivados do aumento da produção do etanol: dossiê Etanol, n.86. ComCiência: Revista Eletrônica de Jornalismo Científico, Brasília. Disponível em: <http://www.comciencia.br/comciencia/?section=8\&tipo =dossie \&edicao=23>. Acesso em: 13 mar.2010.

VIAN, C. E. F. (2003). Agroindústria canavieira: estratégias competitivas e modernização. Campinas: Átomo. 
WCED - WORLD COMISSION ON ENVIRONMENT AND DEVELOPMENT. (1987) Our common Future. Oxford: Oxford University Press.

WEAVER, P.M.; ROTMANS, J. Integrated Sustainability Assessment: What? Why? How?. Working Papper 1. MATISSE - Methods and Tools for Integrated Sustainability Assessment. 2006. Disponível em: $<$ http://www.matisse-project.net>. Acesso em: 14 abr 2010.

WINOGRAD, M.; FARROW, A. (2009). Sustainable development indicators for decision making: concepts, methods, definition and use. In. SEIDLER, R. (Org). Dimensions of sustainable development. Boston: EOLSS Publishers, v.1 e 2.

WOERDEN, J.V. et. al. (2007). GEO Resource Book: a training manual on integrated environmental assessment and reporting. UNEP0 (Training Module 4- monitoring data and indicators). 
APÊNDICE A - Modelo da Tabela de consulta utilizada para entrevista semi-estruturada.

\begin{tabular}{|c|c|c|c|c|c|c|c|c|c|c|}
\hline \multirow[b]{2}{*}{ RQA } & \multirow{2}{*}{$\begin{array}{c}\text { In } \\
\text { d }\end{array}$} & \multirow{2}{*}{ NOME } & \multirow{2}{*}{$\begin{array}{c}\text { OBJETIVO } \\
\text { O indicador busca... }\end{array}$} & \multirow{2}{*}{ Descrição } & \multicolumn{5}{|c|}{ Tópicos de Discussão } & \multirow{2}{*}{$\begin{array}{l}\text { Pontuar de } 0 \text { a } 5 \text {, onde } 5 \text { é o maior grau de } \\
\text { adequação com o tópico questionado. } \\
\text { Tópicos de Discussão } \\
\end{array}$} \\
\hline & & & & & $\mathrm{A}$ & $\mathrm{B}$ & $\mathrm{C}$ & $\mathrm{D}$ & $\mathrm{E}$ & \\
\hline $\begin{array}{l}\text { RH ; } \\
\text { RQAI } \\
\text { (Cetesb) } \\
\text {; PQ }\end{array}$ & 1 & $\begin{array}{l}\text { Redução de carga orgânica } \\
\quad(\operatorname{kg} \text { DBO 5,20/dia) }\end{array}$ & $\begin{array}{l}\text { Avaliar o total de carga } \\
\text { poluidora lançada diariamente } \\
\text { em uma bacia hidrográfica }\end{array}$ & $\begin{array}{l}\text { Percentual de carga poluidora } \\
\text { reduzida (em termos de Kg DBO } \\
5,20 / \text { dia) do total gerado, } \\
\text { considerando-se uma eficiência } \\
\text { de } 80 \% \text { no tratamento. }\end{array}$ & & & & & & $\begin{array}{l}\text { A - Representatividade (grau de relação } \\
\text { que o indicador tem com os impactos } \\
\text { negativos significativos do etanol). }\end{array}$ \\
\hline $\begin{array}{l}\text { RH ; } \\
\text { RQAI } \\
\text { (Cetesb) } \\
\text {; PQ } \\
\end{array}$ & 2 & $\begin{array}{l}\text { IQA (Índice de Qualidade } \\
\text { de Água) }\end{array}$ & $\begin{array}{l}\text { Avaliar a qualidade das águas, } \\
\text { tendo como determinante } \\
\text { principal sua utilização para } \\
\text { abastecimento público }\end{array}$ & $\begin{array}{c}\text { Composto por } 9 \text { parâmetros: } \\
\text { (Temperatura, pH, oxigênio } \\
\text { dissolvido, demanda bioquímica } \\
\text { de oxigênio, coliformes termo- } \\
\text { tolerantes, nitrogênio total, } \\
\text { fósforo total, resíduos totais e } \\
\text { turbidez.) }\end{array}$ & & & & & & $\begin{array}{l}\text { B- Solidez Analítica - grau de validade } \\
\text { científica. }\end{array}$ \\
\hline $\begin{array}{l}\text { RH ; } \\
\text { RQAI } \\
\text { (Cetesb) } \\
\text {; PQ }\end{array}$ & 8 & $\begin{array}{l}\text { IAP (Índice de Qualidade } \\
\text { de Água Bruta para fins de } \\
\text { Abastecimento Público). }\end{array}$ & $\begin{array}{l}\text { Avaliar, além das variáveis } \\
\text { consideradas no IQA, as } \\
\text { substâncias tóxicas e as } \\
\text { variáveis que afetam a } \\
\text { qualidade organoléptica da } \\
\text { água, advindas, principalmente, } \\
\text { de fontes difusas. }\end{array}$ & $\begin{array}{l}\text { (Temperatura, } \mathrm{pH} \text {, oxigênio } \\
\text { dissolvido, demanda bioquímica } \\
\text { de oxigênio, coliformes termoto- } \\
\text { lerantes, nitrogênio total, fósforo } \\
\text { total, resíduos totais e turbidez, } \\
\text { ferro dissolvido, manganês, } \\
\text { alumínio dissolvido, cobre } \\
\text { dissolvido, zinco, potencial de } \\
\text { formação de trihalometanos, } \\
\text { número de células de } \\
\text { cianobactérias, cádmio, chumbo, } \\
\text { cromo total, mercúrio e níquel.) }\end{array}$ & & & & & & $\begin{array}{c}\text { C- Relevância Política do Indicador (grau } \\
\text { de concordância com o quadro legislativo } \\
\text { do governo e questões ambientais de } \\
\text { significância ) }\end{array}$ \\
\hline $\begin{array}{l}\text { RH ; } \\
\text { RQAI } \\
\text { (Cetesb) } \\
\text {; PQ }\end{array}$ & 9 & $\begin{array}{l}\text { IVA (Índice de Qualidade } \\
\text { de Água para a proteção da } \\
\text { Vida Aquática) }\end{array}$ & $\begin{array}{c}\text { Avaliar a qualidade das águas } \\
\text { para fins de proteção da fauna e } \\
\text { flora. Fornece informações não } \\
\text { só sobre a qualidade da água em } \\
\text { termos ecotoxicológicos, como } \\
\text { também sobre o seu grau de } \\
\text { trofia. } \\
\end{array}$ & $\begin{array}{l}\text { Incluídas as variáveis essenciais } \\
\text { para a vida aquática (oxigênio } \\
\text { dissolvido, PH e toxidade), } \\
\text { substâncias tóxicas, além das } \\
\text { variáveis do IET, clorofila a e } \\
\text { fósforo total. }\end{array}$ & & & & & & $\begin{array}{l}\text { D- Grau de Abrangência do indicador: no } \\
\text { que se refere aos dados, o indicador deve } \\
\text { apresentar limites bem definidos no } \\
\text { espaço, de forma a facilitar, geográfica e } \\
\text { operacionalmente, o gerenciamento das } \\
\text { propostas do planejamento. }\end{array}$ \\
\hline RH & 10 & $\begin{array}{l}\text { Densidade da rede de } \\
\text { monitoramento das águas } \\
\text { superficiais }\end{array}$ & $\begin{array}{l}\text { Avaliar o controle da qualidade } \\
\text { e disponibilidade dos recursos } \\
\text { hídricos. }\end{array}$ & $\begin{array}{c}\text { Número de postos de } \\
\text { monitoramento de águas } \\
\text { superficiais, dividido pela área do } \\
\text { Estado (área do estado dividida } \\
\text { por 1000). } \\
\end{array}$ & & & & & & $\begin{array}{l}\text { E- Conformidade temporal: intervalo de } \\
\text { tempo aceitável entre a coleta do dado e a } \\
\text { realidade que se deseja representar. }\end{array}$ \\
\hline
\end{tabular}


APÊNDICE B - Dinâmica apresentada na Oficina de especialistas.

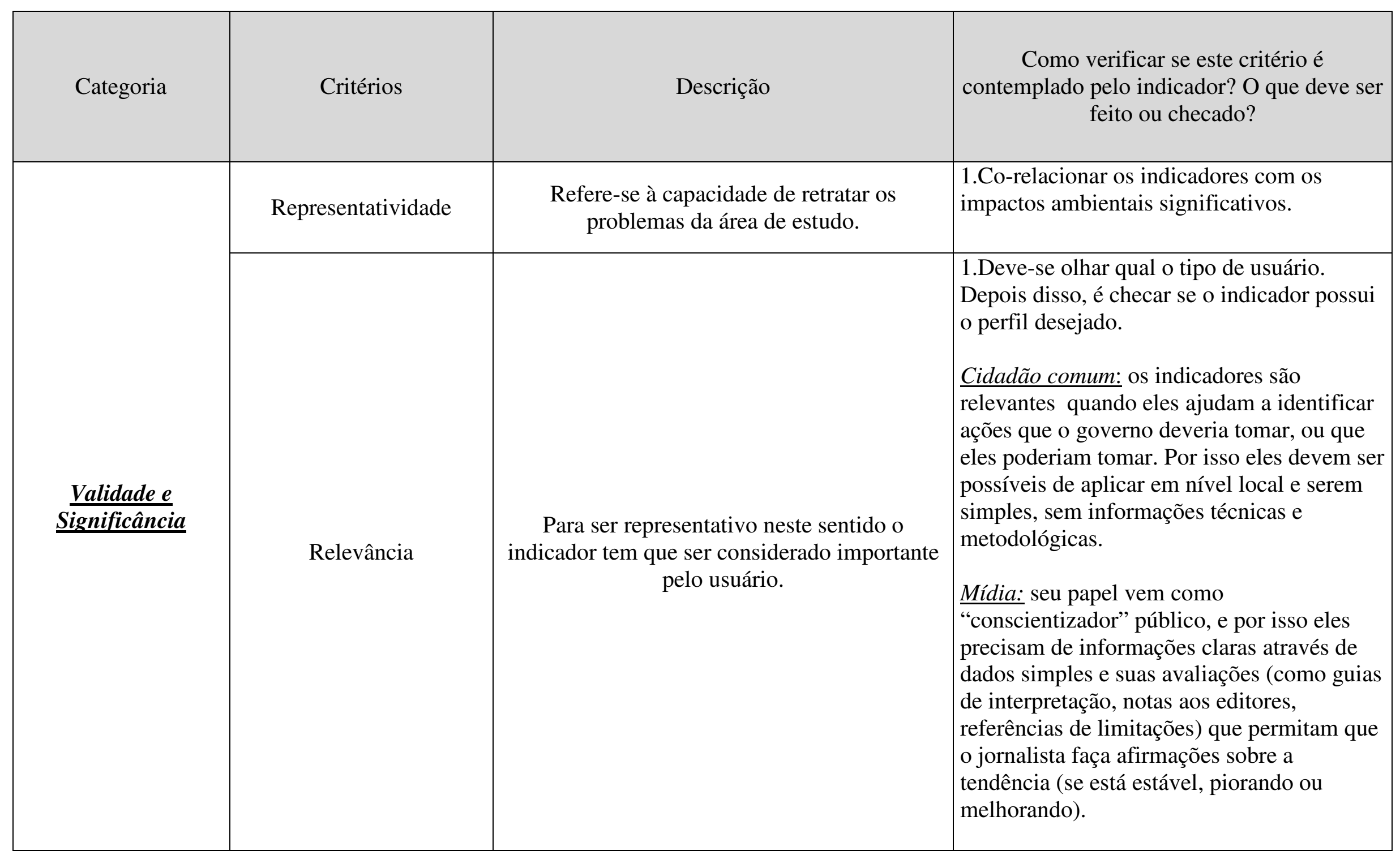




\begin{tabular}{|c|c|c|c|}
\hline$\frac{\text { Validade e }}{\text { Significância }}$ & Relevância (cont.) & $\begin{array}{l}\text { Para ser representativo neste sentido o } \\
\text { indicador tem que ser considerado importante } \\
\text { pelo usuário. }\end{array}$ & $\begin{array}{l}\text { Tomadores de decisão: precisam de } \\
\text { informações que forneçam uma visão geral, } \\
\text { mas com alguma avaliação /análise que } \\
\text { destaque áreas onde ações deveriam ser } \\
\text { tomadas. Metas são importantes. } \\
\text { SMA: como esta implementa a política } \\
\text { ambiental e fiscalização, é necessário uma } \\
\text { ampla gama de indicadores claramente } \\
\text { definidos e criteriosos em termos de } \\
\text { métodos, que possam monitorar o progresso } \\
\text { ao longo do tempo (histórico, evolução, } \\
\text { tendência), com metas claras e objetivos. } \\
\text { ONGs: precisam de informação que sejam } \\
\text { disponíveis e de fácil acesso para que usem } \\
\text { em campanhas de conscientização pública e } \\
\text { para lobby político. } \\
\text { Formuladores de política: trabalham com } \\
\text { conjunto de indicadores, e este deve ser } \\
\text { compreensível e possuir interligações entre } \\
\text { os pilares, ou seja, indicadores de } \\
\text { sustentabilidade. } \\
\text { Núcleos de pesquisa: necessitam de } \\
\text { informações detalhadas, sobre a } \\
\text { confiabilidade dos dados, a metodologia } \\
\text { utilizada, outros. }\end{array}$ \\
\hline
\end{tabular}




\begin{tabular}{|c|c|c|c|}
\hline \multirow{5}{*}{$\frac{\underline{\text { Validade e }}}{\text { Significância }}$} & Relevância (cont.) & $\begin{array}{c}\text { Para ser representativo neste sentido o } \\
\text { indicador tem que ser considerado importante } \\
\text { pelo usuário. }\end{array}$ & $\begin{array}{l}\text { Industria: ? (sugestões) } \\
\frac{\text { Governo Local:? (sugestões) }}{2 \ldots} \\
2 \ldots\end{array}$ \\
\hline & Significância & $\begin{array}{c}\text { O indicador sendo de âmbito regional ou } \\
\text { nacional deve ser aplicável às questões } \\
\text { ambientais de significância nacional ou global. }\end{array}$ & $\begin{array}{l}\text { 1.Descrever uma problemática nacional a } \\
\text { qual comprove a importância em se utilizar } \\
\text { daquele indicador em todos os âmbitos. } \\
2 \ldots\end{array}$ \\
\hline & Valores de Referência & $\begin{array}{l}\text { Os indicadores devem utilizar-se de valores de } \\
\text { referência (meta ou um limite) para que o } \\
\text { usuário possa estabelecer comparações e julgar } \\
\text { a importância dos valores associados a ele. }\end{array}$ & $\begin{array}{l}\text { 1.Checar a indicação destes valores de } \\
\text { referência na apresentação dos resultados } \\
\text { (nos relatórios de qualidade ambiental } \\
\text { utilizado como norteador da pesquisa, ou no } \\
\text { site da instituição) e sua qualidade ( se o } \\
\text { mesmo é normativo, ou internacionalmente } \\
\text { reconhecido). } \\
2 \ldots\end{array}$ \\
\hline & $\begin{array}{l}\text { Sensibilidade às } \\
\text { mudanças }\end{array}$ & $\begin{array}{l}\text { À medida que ocorrem as alterações no ambiente, } \\
\text { mesmo que pequenas, a resposta do dado é } \\
\text { imediata, mudando o seu valor; e se for de natureza } \\
\text { preventiva que seja capaz de sinalizar a degradação } \\
\text { antes da ocorrência de sérios danos. }\end{array}$ & $\begin{array}{l}\text { Importante, porém aplicável somente com } \\
\text { apoio de especialista. } \\
\text {... }\end{array}$ \\
\hline & Series temporais & $\begin{array}{l}\text { Se a sensibilidade às mudanças se mantém ao } \\
\text { longo do tempo, podem-se gerar séries } \\
\text { temporais de dados (lineares, cíclicos, outros) } \\
\text { sendo estas ótimas tradutoras dos fenômenos } \\
\text { de diferentes dinâmicas em um determinado } \\
\text { tempo. Quando for importante a analise da } \\
\text { evolução, os indicadores devem ter a } \\
\text { capacidade de expressar as mudanças em uma } \\
\text { escala de tempo compatível com os problemas. }\end{array}$ & $\begin{array}{l}\text { 1.Confirmar nos relatórios de qualidade } \\
\text { ambiental (norteador da pesquisa) se os } \\
\text { resultados e análise comentam ou } \\
\text { apresentam séries temporais do indicador. } \\
2 \ldots\end{array}$ \\
\hline
\end{tabular}




\begin{tabular}{|c|c|c|c|}
\hline & Fácil compreensão & $\begin{array}{l}\text { Indicadores devem ser simples e fáceis de } \\
\text { compreender, para informar o grupo de } \\
\text { pessoas que tomará as decisões quantos aos } \\
\text { rumos do planejamento. }\end{array}$ & $\begin{array}{l}1 \ldots \\
2 \ldots\end{array}$ \\
\hline$\frac{\underline{\text { Validade e }}}{\text { Significância }}$ & Tipo de informação & $\begin{array}{l}\text { Deve-se considerar se a informação é } \\
\text { prescritiva - aquela que é analítica e apresenta } \\
\text { recomendações ao desenvolvimento de } \\
\text { alternativas, constituindo um bom indicador. } \\
\text { Ou se é Informação descritiva: restringe-se à } \\
\text { descrição das propriedades do meio, sem a } \\
\text { pretensão de fornecer subsídios diretos à } \\
\text { tomada de decisão. }\end{array}$ & $\begin{array}{l}1 \ldots \\
2 \ldots\end{array}$ \\
\hline$\underline{\text { Solidez Analítica }}$ & Validade Científica & Ter fundamentos científicos e técnicos. & $\begin{array}{l}\text { 1. Pode ser feita uma validade baseada por } \\
\text { comparação com outros indicadores que } \\
\text { objetivam medir a mesma coisa. }\end{array}$ \\
\hline$\underline{\text { Disponibilidade }}$ & Disponibilidade e Acesso & Estar disponível e ser fácil de obter. & $\begin{array}{l}\text { 1. Verificar se é fornecido pelo site da SMA } \\
\text { / instituições vinculadas ou nos Relatórios } \\
\text { de Qualidade Ambiental. } \\
2 \ldots\end{array}$ \\
\hline \multirow[b]{2}{*}{$\underline{\text { Mensurabilidade }}$} & Atualização e divulgação & $\begin{array}{l}\text { Os dados precisam ser coletados e reportados } \\
\text { regularmente, devendo haver um tempo } \\
\text { mínimo entre a coleta e a reportagem, para } \\
\text { garantir a atualidade e utilidade para o usuário. }\end{array}$ & $\begin{array}{l}\text { 1. Verificar ( nos Relatórios e site da SMA) } \\
\text { se há informação sobre o indicador ser } \\
\text { periodicamente atualizado e disponibilizado } \\
\text { logo em seguida. } \\
2 \ldots\end{array}$ \\
\hline & Abrangência do indicador & $\begin{array}{l}\text { No que se refere a dados espacializados, o } \\
\text { indicador deve apresentar limites bem definidos no } \\
\text { espaço, de forma a facilitar, geográfica e } \\
\text { operacionalmente, o gerenciamento das propostas } \\
\text { do planejamento. Em outras palavras, deve haver } \\
\text { compatibilidade entre a escala da informação e a } \\
\text { escala adotada para o estudo. }\end{array}$ & $\begin{array}{l}1 \ldots \\
2 \ldots\end{array}$ \\
\hline
\end{tabular}




\begin{tabular}{|c|c|c|c|}
\hline$\frac{\text { Mensurabilidade }}{\underline{\text { cont.. })}}$ & Conformidade Temporal & $\begin{array}{c}\text { Deve-se averiguar o tempo decorrido entre a } \\
\text { coleta do dado e a realidade que se deseja } \\
\text { representar. Neste aspecto, é evidente que para } \\
\text { cada temática, há um intervalo de tempo } \\
\text { aceitável, que deve ser julgado pelo seu } \\
\text { especialista. }\end{array}$ & $\begin{array}{l}\text { Importante, porém aplicável somente com } \\
\text { apoio de especialista. }\end{array}$ \\
\hline \multirow{5}{*}{$\frac{\frac{\text { Sistematizacão do }}{\text { conjunto de }}}{\underline{\text { indicadores }}}$} & Conectividade & $\begin{array}{c}\text { Conectividade do indicador com outros do } \\
\text { meio, ou seja, os elos de ligação entre as } \\
\text { diversas informações e as respostas integradas } \\
\text { às suas mudanças. }\end{array}$ & $\begin{array}{l}1 \ldots \\
2 \ldots\end{array}$ \\
\hline & Integração & $\begin{array}{l}\text { É importante observar se o indicador é } \\
\text { integrador, se tem a capacidade de sintetizar } \\
\text { informações de vários outros indicadores. }\end{array}$ & $\begin{array}{l}1 \ldots \\
2 \ldots\end{array}$ \\
\hline & Participação popular & $\begin{array}{l}\text { Em algum momento, ou na elaboração ou } \\
\text { revisão dos indicadores. }\end{array}$ & $\begin{array}{l}\text { 1.Verificar (nos Relatórios e site da SMA) } \\
\text { se há informação sobre participação popular } \\
2 \ldots\end{array}$ \\
\hline & $\begin{array}{l}\text { Uso de um modelo } \\
\text { conceitual estrutural }\end{array}$ & $\begin{array}{l}\text { Usado como guia para o desenvolvimento e } \\
\text { estruturação de um conjunto de indicadores, de } \\
\text { uma forma coerente. Sem ele, o conjunto se } \\
\text { torna uma mistura eclética de indicadores, sem } \\
\text { qualquer justificação clara para a sua seleção. }\end{array}$ & $\begin{array}{l}\text { 1.Verificar nos Relatórios de Qualidade } \\
\text { Ambiental a utilização de um modelo } \\
\text { conceitual. } \\
2 \ldots\end{array}$ \\
\hline & Redundância & $\begin{array}{c}\text { Deve se tomar cuidado para que o indicador } \\
\text { não a apresente, ou seja, que diferentes dados } \\
\text { coletados não expressem a mesma informação. }\end{array}$ & $\begin{array}{l}\text { 1.Verificar na estruturação do conjunto de } \\
\text { indicadores (nos Relatórios e site da SMA). } \\
2 \ldots\end{array}$ \\
\hline
\end{tabular}


APÊNDICE C - Entrevista semi-estruturada ao especialista perito.

Nome:

Especialista / dimensão:

Indicador:

\section{$\underline{\text { Relevância }}$}

Para ser representativo neste sentido o indicador tem que ser considerado importante pelo seu usuário.

\begin{tabular}{|ll}
\hline Verificação & Opinião do Especialista \\
\hline $\begin{array}{l}\text { Processo participativo de discussão com usuários em algum } \\
\text { momento da história do indicador. }\end{array}$ & $\square$ Sim. \\
& $\square$ (Parcialmente).
\end{tabular}

\section{Significância}

O indicador sendo de âmbito regional ou nacional deve ser aplicável às questões ambientais de significância nacional ou global.

\begin{tabular}{|ll|}
\hline Verificação & Opinião do Especialista \\
\hline Relação com macro projetos, programas, políticas e /ou leis. & $\square$ Sim. (Quais?) \\
& $\square$ Não. \\
\hline $\begin{array}{l}\text { Relação com problemáticas ambientais vinculadas a sustenta- } \\
\text { bilidade do etanol. }\end{array}$ & $\square$ Sim (Comente). \\
\hline Não.
\end{tabular}

\section{Valores de Referência}

Os indicadores devem utilizar-se de valores de referência (meta ou um limite) para que o usuário possa estabelecer comparações e julgar a importância dos valores associados a ele.

Verificacão $\quad$ Opinião do Especialista

O indicador possui valores de referência que incorporam $\square$ Sim (Justifique).

capacidade de suporte do meio.

Não (Indica que são valores de referência somente normativos).

\section{Conformidade temporal}

À medida que ocorrem as alterações no ambiente, mesmo que pequenas, a resposta do dado é imediata, mudando o seu valor; deve-se averiguar o tempo decorrido entre a coleta do dado e a realidade que se deseja representar. Neste aspecto, é evidente que para cada temática, há um intervalo de tempo aceitável, que deve ser julgado pelo seu especialista.

Verificacão Opinião do Especialista

Ao considerar o ciclo do impacto ambiental significativo o método é sensível as mudanças.

$\square$ Sim (O tipo de monitoramento que está sendo feito é capaz de captar as oscilações que ocorrem no aspecto mensurado).

$\square$ Não.

\section{Séries Temporais}

Séries temporais de dados (lineares, cíclicos ou sazonais) são ótimos tradutores dos fenômenos de diferentes dinâmicas em um determinado tempo. Quando for importante a analise da evolução, os indicadores devem ter a capacidade de expressar as mudanças em uma escala de tempo compatível com os problemas.

Verificação Opinião do Especialista

O monitoramento está sendo realizado com o objetivo de embasar avaliações futuras, sejam de tendências e /ou formação de cenários futuros. $\square$ Sim (Indica a existência de padrão histórico de coleta e análise). 

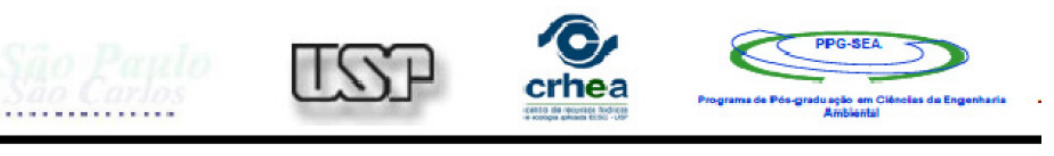

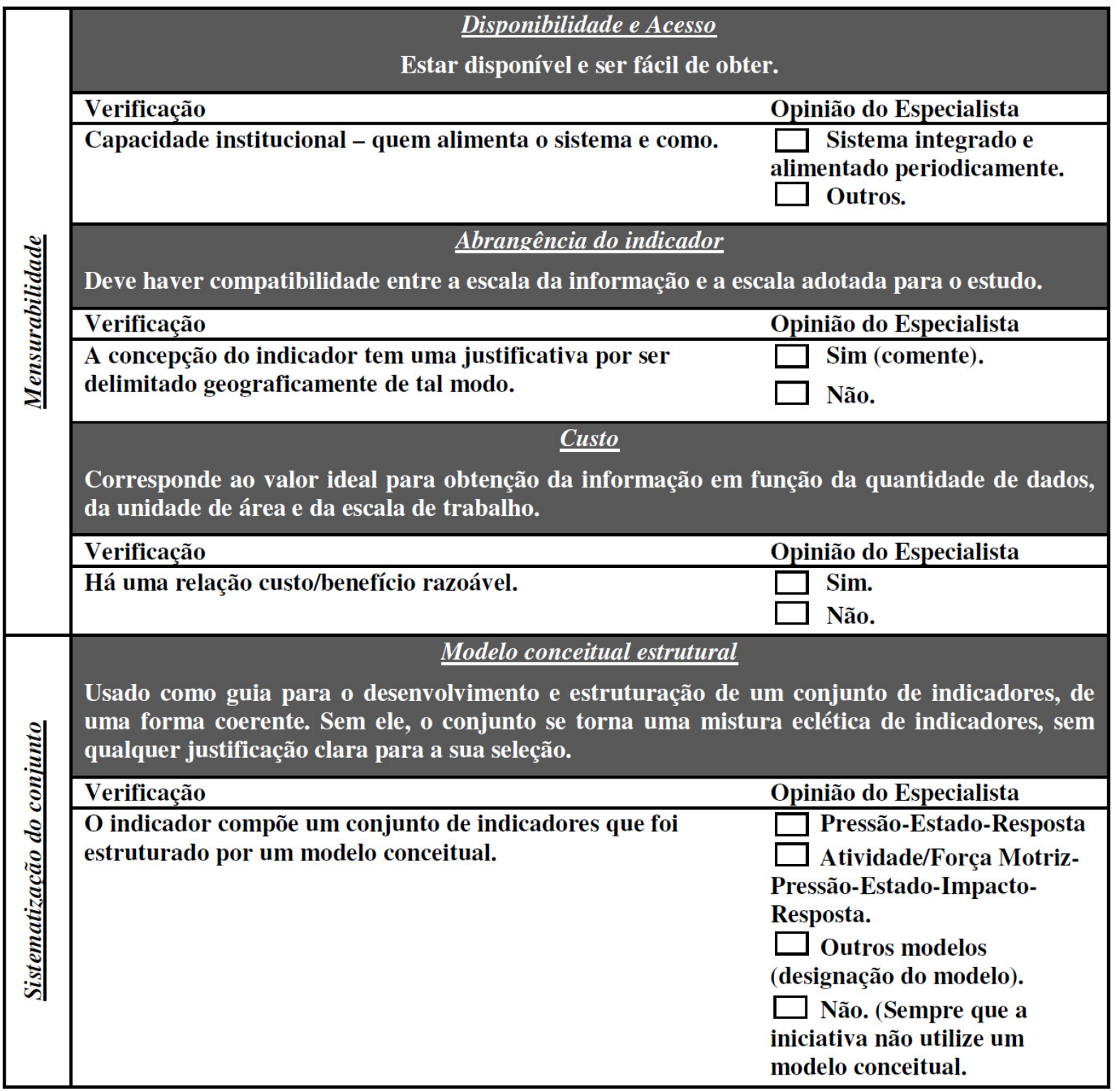

Observações: 
APÊNDICE D - Descrição dos Índices inseridos no conjunto de indicadores-chave.

\begin{tabular}{|c|c|c|c|}
\hline Componente Ambiental & Índice & Descrição & $\begin{array}{c}\text { Composição (indicadores que compõem o } \\
\text { índice). }\end{array}$ \\
\hline Água & IQA (Índice de Qualidade de Água & $\begin{array}{c}\text { Avaliar a qualidade das águas, tendo como } \\
\text { determinante principal sua utilização para } \\
\text { abastecimento público }\end{array}$ & $\begin{array}{c}\text { Composto por } 9 \text { parâmetros: (Temperatura, } \mathrm{pH} \text {, } \\
\text { oxigênio dissolvido, demanda bioquímica de } \\
\text { oxigênio, coliformes termo tolerantes, } \\
\text { nitrogênio total, fósforo total, resíduos totais e } \\
\text { turbidez.) }\end{array}$ \\
\hline Água & $\begin{array}{c}\text { IAP (Índice de Qualidade de Água } \\
\text { Bruta para fins de Abastecimento } \\
\text { Público). }\end{array}$ & $\begin{array}{c}\text { Avalia as variáveis } \\
\text { consideradas no IQA mais o ISTO (Índice de } \\
\text { Substâncias Tóxicas e Organolépticas), que é } \\
\text { composto pelo grupo de substâncias que afetam a } \\
\text { qualidade organoléptica da água, bem como de } \\
\text { substâncias tóxicas, advindas, principalmente, de } \\
\text { fontes difusas. }\end{array}$ & $\begin{array}{l}\text { (Temperatura, } \mathrm{pH} \text {, oxigênio dissolvido, } \\
\text { demanda bioquímica de oxigênio, coliformes } \\
\text { termo tolerantes, nitrogênio total, fósforo total, } \\
\text { resíduos totais e turbidez, ferro dissolvido, } \\
\text { manganês, alumínio dissolvido, cobre } \\
\text { dissolvido, zinco, potencial de formação de } \\
\text { trihalometanos, número de células de } \\
\text { cianobactérias, cádmio, chumbo, cromo total, } \\
\text { mercúrio e níquel.) }\end{array}$ \\
\hline Água & IET (Índice do Estado Trófico) & $\begin{array}{l}\text { Tem por finalidade classificar os corpos d'água } \\
\text { em diferentes graus de trofia, } \\
\text { ou seja, avalia a qualidade da água quanto ao } \\
\text { enriquecimento por nutrientes e seu efeito } \\
\text { relacionado ao crescimento } \\
\text { excessivo das algas ou ao aumento da infestação } \\
\text { de macrófitas aquáticas. Avalia a qualidade da } \\
\text { água quanto ao enriquecimento por nutrientes. }\end{array}$ & $\begin{array}{l}\text { Para o cálculo do IET são consideradas as } \\
\text { variáveis: clorofila a e fósforo total. }\end{array}$ \\
\hline Água & $\begin{array}{l}\text { IVA (Índice de Qualidade de Água } \\
\text { para a proteção da Vida Aquática) }\end{array}$ & $\begin{array}{l}\text { Avalia a qualidade das águas para fins de } \\
\text { proteção da fauna e flora. Fornece informações } \\
\text { não só sobre a qualidade da água em termos } \\
\text { ecotoxicológicos, como também sobre o seu grau } \\
\text { de trofia. }\end{array}$ & $\begin{array}{c}\text { Incluídas as variáveis essenciais para a vida } \\
\text { aquática (oxigênio dissolvido, PH e toxidade), } \\
\text { substâncias tóxicas, além das variáveis do IET, } \\
\text { clorofila a e fósforo total. }\end{array}$ \\
\hline
\end{tabular}

